Portland State University

PDXScholar

$1-1-1979$

\title{
Public sector collective bargaining and impasse resolution: an analysis of the Oregon fact-finding process
}

Martin David Haney

Portland State University

Follow this and additional works at: https://pdxscholar.library.pdx.edu/open_access_etds Let us know how access to this document benefits you.

Recommended Citation

Haney, Martin David, "Public sector collective bargaining and impasse resolution: an analysis of the Oregon fact-finding process" (1979). Dissertations and Theses. Paper 836.

https://doi.org/10.15760/etd.836

This Dissertation is brought to you for free and open access. It has been accepted for inclusion in Dissertations and Theses by an authorized administrator of PDXScholar. Please contact us if we can make this document more accessible: pdxscholar@pdx.edu. 


\title{
PUBLIC SECTOR COLLECTIVE BARGAINING AND IMPASSE \\ RESOLUTION: AN ANALYSIS OF THE OREGON \\ FACT-FINDING PROCESS
}

\author{
by \\ MARTIN DAVID HANEY
}

A dissertation submitted in partial fulfillment of the requirements for the degree of

\author{
DOCTOR OF PHILOSOPHY \\ in \\ URBAN STUDIES
}

\author{
Portland State University \\ 1979 \\ Martin D. Haney (C) 1979
}


TO THE OFFICE OF GRADUATE STUDIES AND RESEARCH:

The members of the Committee approve the dissertation of Martin David Haney presented May 18, 1979.

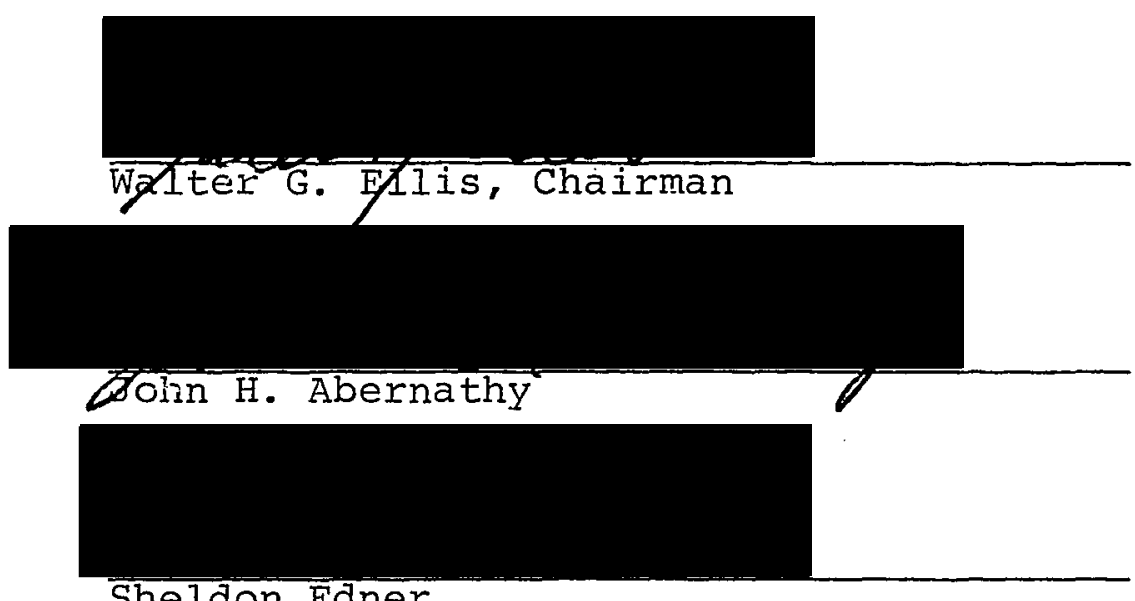

Sheldon Edner

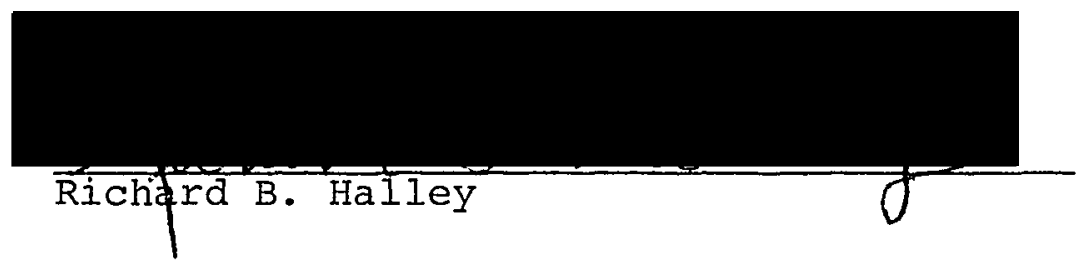

APPROVED :

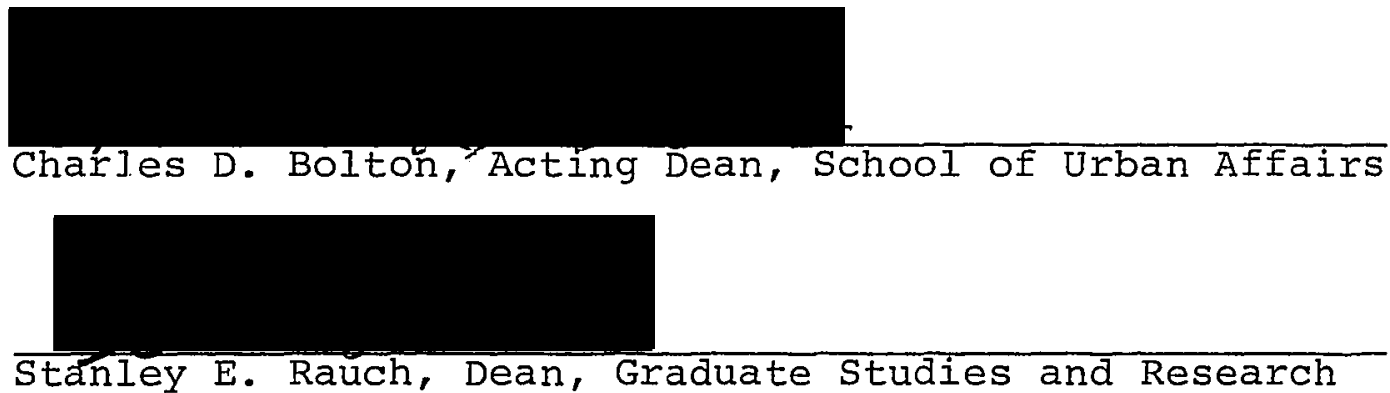


TABLE OF CONTENTS

PAGE

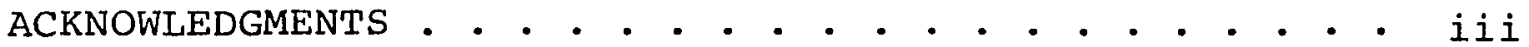

LIST OF TABLES . . . . . . . . . . . . . . . . . viii LIST OF FIGURES . . . . . . . . . . . . . . . . . . . xii

CHAPTER

I INTRODUCTION • . . . . . . . . . . . . . . 1

Overview •. • . . . . . . . . . . 1

Purpose and Scope . . . . . . . . . 3

The Significance of the Study . . . . . 4

Methodology . . . . . . . . . . . 9

Summary and Format . . . . . . . 11

Chapter I Notes... . . . . . . 13

I I COLLECTIVE BARGAINING IN THE PUBLIC

SECTOR: THE NATIONAL SCENE • . . . . . 16

General Aspects . . . . . . . . . 16

The Philosophical Debate Over

Public Sector Collective Bargaining . . 17

The Growth of Public Employment

and Reasons for Public Employee

Organization . . . . . . . . . . . . 26

The Evolution and Impact of Public

Employee Collective Bargaining Law • • 27

Chapter II Notes . . . . . . . 49 
III THE LEGAL SETTING AND EXTENT OF

COLLE'CTIVE BARGAINING IN OREGON

The Purpose of the Law . . . . . . 58

Major Provisions of Oregon Law . . . 58

Oregon's Public Sector . . . . . . 65

Impact Study . . . . . . . . . . 72

Chapter III Notes . . . . . . . . 80

IV THE GENERAL NATURE AND THEORETICAL

BASIS OF IMPASSE RESOLUTION IN THE

PUBLIC SECTOR • • • • • • • • • • • • • • 83

The Purpose . . . . . . . . . . 83

Impasse Resolution Law . . . . . . 85

Federal Sector . . . . . . . 85

State Legislation . . . . . . 87

Characteristics of Impasse

Resolution . . . . . . . . . . 89

Mediation . . . . . . . . . 89

Fact-Finding . . . . . . . . . . 91

Interest Arbitration . . . . . 104

Chapter IV Notes . . . . . . . . 112

$V$ OREGON'S IMPASSE PROCEDURE AND

AGGREGATE DATA ANALYSIS • . • • . • . . . 119

Oregon's Impasse Procedure . . . . 121

Methodology for the Aggregate Data • • 126

Analysis of the Aggregate Data . . . 127

Numbers and Types of Issues . . . . . 133 


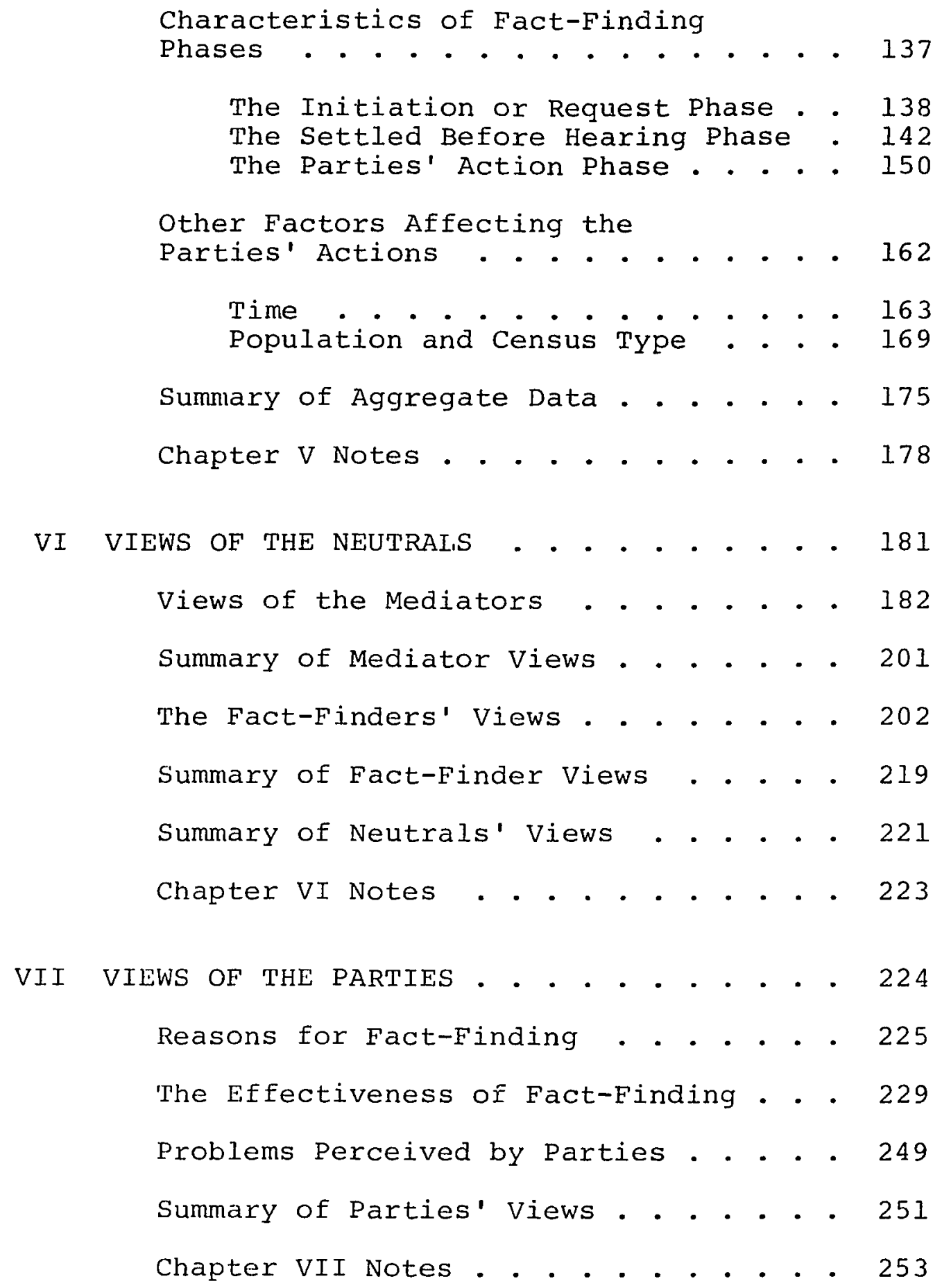


VIII SUMMARY, CONCLUSIONS AND RECOMMENDATIONS • 254

Summary of Aggregate Data . . . . - 257

Summary of Participants' Views . . • 259

Problems and Proposed Solutions . . . 264

Areas for Future Research . . . . . 274

The Future . . . . . . . . . . . 275

SOURCES CONSULTED . . . . . . . . . . . . 277

APPENDICES . . . . . . . . . . . . . . 286 


\section{LIST OF TABLES}

TABLE

PAGE

I Exclusive Recognitions and Agreements by Major Union, November 1975 . • • • . 30

II Total Employees in Exclusive Units and Covered by Agreement, 1963-1974 . . . . 30

II Membership of State and Local Government Unions, 1964-1976 . . . . . . . 34

IV Distribution of States by Percent of Full-Time Employees Organized . . . • . 35

$\mathrm{V}$ Organized Full-Time Employees, by Level and Type of Government . . . . . . 35

VI Percent of Full-Time Employees Organized, by Function and Level of Government . . . . . . . . . .

VII Governments With A Labor Relations Policy, by Level and Type of Government . . . . . . . . . . . .

VIII Labor-Management Agreements, by Level and Type of Government . . . . . 38

IX State and Local Government Work Stoppages, by Level and Type of Government . . . . . . . . . . . . .

$\mathrm{X}$ State and Local Government Work Stoppages by Function . . . . . . . . .

XI Numbers of Oregon Public Employees: by Level of Government and Function December 1974 - December 1977 . . . . .

XII State and Local Government Organized Employees, by Type of Government, October 1975 and October 1976 . . . .

XIII State and Local Government Organized Employees, by Function, October 1975 and October 1976 . . . . . . . . . . 
XIV State and Local Government Labor Relations Policies, Bargaining Units, and Represented Employees, by State and Type of Government: October 1976 . . . 71

$X V$ Actual and Possible Bargaining Units by Type of Government, by Population in Oregon ............... 76

XVI Disposition of Cases Going to Impasse in Oregon, 1974-1977 ... . . . . . . 128

XVII Number of Issues Submitted to FactFinding, 1974-1977 . . . . . . . . 134

XVIII Frequent Issues Submitted in Teaching Cases, 1974-1977... . . . . . . . . 136

XIX Mosi Frequent Issues Submitted in Non Teaching Cases... . . . . . . . . 137

XX Oregon Fact-Finding Requests by Employee Organizations, 1974-1977... . . . .

XXI Oregon Fact-Finding Requests by Type of Government (Employer), 1974-1977.. •. . 141

XXII Oregon Fact-Finding Requests by Year . . . 142

XXIII Oregon Fact-Finding Cases Settled Before Hearing by Sector, 1974-1977 . . . 144

XXIV Oregon Fact-Finding Cases settled Before Hearing by Employee Organization, 1974-1977 . . . . . . . . 145

XXV Oregon Fact-Finding Cases Settled Before Hearing by Type of Government Employer, 1974-1977 . . . . . . . . 147

XXVI Oregon Fact-Finding Cases settled Before Hearing by Population Category, 1974-1977 . . . . . . . . 148

XXVII Oregon Fact-Finding Cases settled Before Hearing by Census Type, $1974-1977$

XXVIII E'mployee and E'mployer Action on Oregon Fact-Finding Reports, 1974-1977 
XXIX Sector by Employee Action on Oregon

Fact-Finding Reports, 1974-1977 .. . . 153

XXX Employee Organization by Employee

Action on Oregon Fact-Finding

Reports, 1974-1977........... 154

XXXI Type of Government by Employee Action

on Oregon Fact-Finding Reports,

1974-1977 ............ 156

XXXII Sector by Employer Action on Oregon

Fact-Finding Reports, 1974-1977 . . . . 158

XXXIII Type of Government by Employer Action

on Oregon Fact-Finding Reports, $1974-1977$. . . . . . . . . . 159

XXXIV Employee Organization by Employer Action on Oregon Fact-Finding Reports, $1974-1977$. . . . . . . . . . 160

XXXV Frequency Distribution of Time Phase 1 Request to Hearing and Time Phase 2 Hearing to Report .......... 164

XXXVI Time Lapse Request to Hearing and

Hearing to Report by Employee Action on Oregon Fact-Finding Reports, 1974-1977 ............ 167

XXXVII Time Lapse Request to Hearing and

Hearing to Report by Emplover Action on Oregon Fact-Finding Reports, 1974-1977 ............ 168

XXXVIII Oregon Fact-Finding Requests by Population Category and Census Type, 1974-1977 ............ 170

XXXIX Population and Census Type by Employee Action on Oregon Fact-Finding Reports, 1974-1977 ............ . 172

XXXX Population and Census T'ype by Employer Action on Oregon Fact-Finding Reports, 1974-1977 ........... 173

XXXXI. Summary of Fact-Finding Data . . . . . 176 


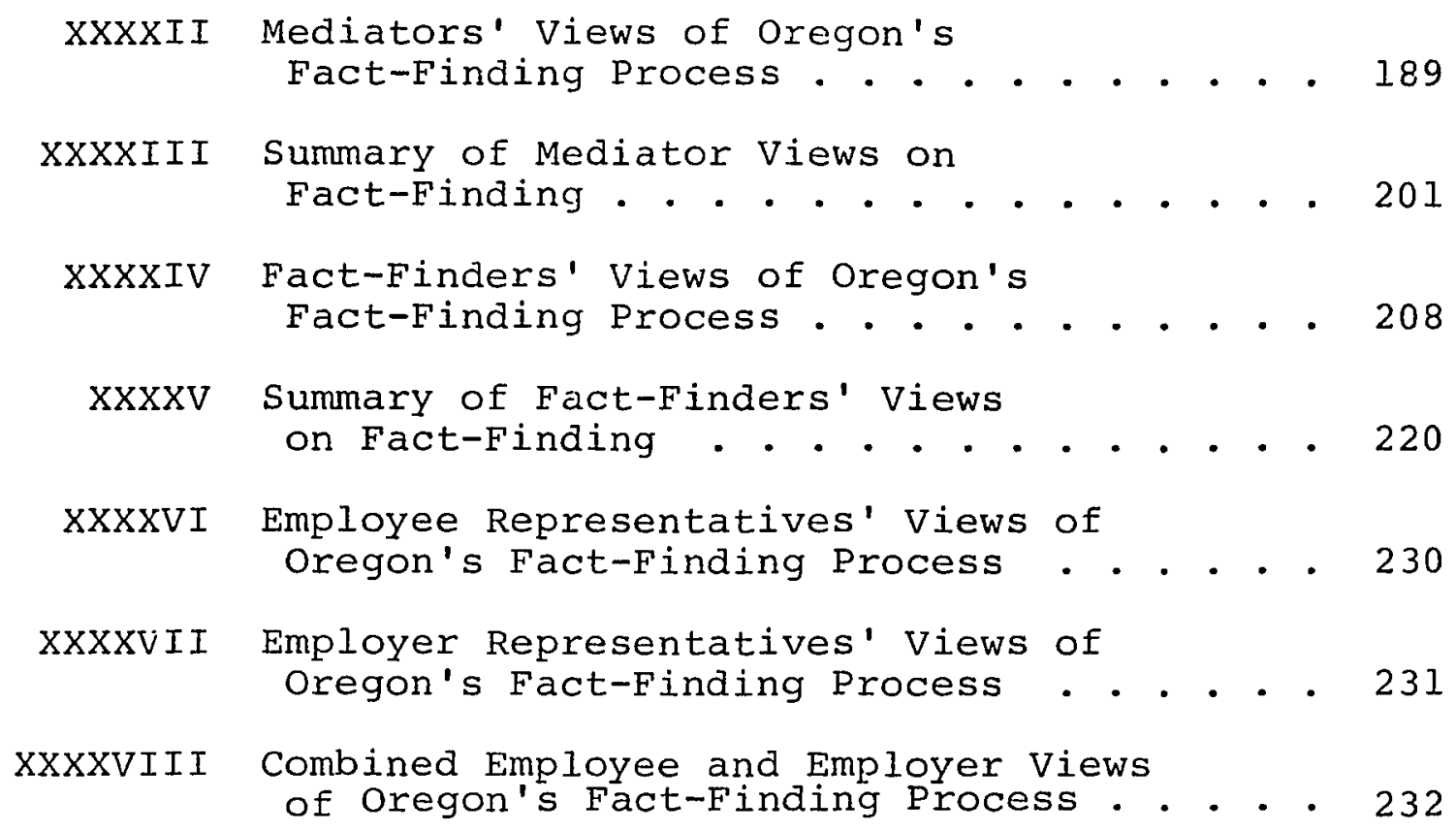




\section{LIST OF FIGURES}

FIGURE PAGE

1. Oregon's Impasse Resolution Process . . . . . . 61

2. Impasse Procedures Under Oregon's Public Sector Collective Bargaining Law . . . 120

3. Oregon's Impasse Resolution Process . . . . . 256 


\section{CHAPTER I}

\section{INTRODUCTION}

OVERVIEW

The topic of this dissertation is the fact-finding stage of Oregon's public sector impasse resolution procedure. The use of fact-finding has dramatically increased because of the recent and rapid growth in public sector collective bargaining, and the resulting increase in pubIic sector strikes.

Beginning in 1962 with John F. Kennedy's Executive Order 10988, a series of federal and state laws were passed granting and expanding collective bargaining rights to public employees.

Many of the state laws resemble the private sector model provided under the Labor Management Relations Act of 1947 (Taft-Hartley) ${ }^{l}$ however, the use of the strike as a weapon to enforce bargaining in good faith and resolution of conflict has been limited for public employees because of the potential threat of disruption of public services and interference with the sovereignty of the government. ${ }^{2}$ such anti-strike legislation, however, has not prevented public employee strikes. 
Public employee strikes are of particular concern to urban areas for it is within them that the vast majority of population resides, where public employees are concentrated, and where public services are vital to health, safety, and welfare of the citizens. ${ }^{3}$

A major area of controversy and challenge to the public sector, then, is to develop political substitutes for the strike (which is basically an economic threat) that are compatible with the collective bargaining and labor rights guaranteed the private sector, yet at the same time protect government functions from serious disruptions. 4 These substitutes usually have taken the form of mediation, fastfinding, mandatory cooling-off periods, and interest arbitration. However, the variety of ways in which these forms have been developed reflect the controversy over which form and/or combination of forms is the most viabie method of impasse resolution. 5

The state of Oregon is no exception to this endeavor. In October 1973 the Oregon State Legislature passed a comprehensive public employee collective bargaining act which, unlike the vast majority of states, includes the right to strike for all public employees, except those in the protective services of fire, police, and institutional guards. 6 The law also sets up specific steps for impasse resolution should collective negotiations break down. The steps form a procedure that is viewed as a filtering down process, with each step contributing significantly to the orderly 
resolution of disputes, and reducing the possibility of pubIic employee strike. The steps follow the familiar pattern of mediation, fact-finding, and a cooling-off period. If these steps are unsuccessful they may be followed by strike, or compulsory interest arbitration for the protective services. 7

Now with over four years of experience, the factfinding phase of Oregon's impasse resolution process has become quite controversial. The personal views of union, management, and neutrals (mediators and fact-finders) differ considerably as to whether fact-finding does what it is intended to accomplish. There have been recommendations prepared for presentation to the next legislature that would abolish the fact-finding step in this elaborate impasse procedure. 8

The controversy in Oregon reflects the controversy among the experts nationally, and the same situation with respect to academic research in this area prevails; that is, there has been little systematic investigation into the fact-finding process. 9

THE PURPOSE AND SCOPE OF THE STUDY

The purpose of this study is to analyze the purpose, nature, and effectiveness of Oregon's fact-finding phase of impasse resolution. Because of the impact the home rule issue has had on the use of Oregon's impasse procedures, this study will focus on those sectors where use of fact-finding 
has been extensive, consistent and unaffected by the home rule issue. 10 This analysis of fact-finding represents the first comprehensive and systematic assessment of the impasse procedure to be undertaken in the state since the 1973 law was passed. Such analysis will identify the significant variables in the efficacy of fact-finding and will bring together practitioners' views on the viability of the process. This latter dimension is critical in that the opinions of these participants in the labor relations field will likely affect and shape future legislation on fact-finding.

\section{THE SIGNIFICANCE OF THE STUDY}

There are three ways in which this study is significant. First, heretofore, little systematic research and analysis of fact-finding in oregon has been undertaken. This study will establish a basic data base and serve as a basis for future research in oregon and in other states using this type of impasse model. Secondly, this study will add to the base of knowledge accumulated nationally upon which further studies and models of public sector impasse resolution can be built and tested. Thirdly, the study will be of importance to Oregon policy makers who will be considering changes in the present portion of the state law relating to impasse procedure.

These contributions should be placed within the context of the present and potential impact of collective bargaining and strike on the urban area. Because the growth of public 
sector employee organization, collective bargaining and strike has been recent and rapid, the total political and economic impact is not known. However, the burden of strike on the public health, welfare and safety has been experienced throughout the nation. It is of prime importance then to develop impasse resolution procedures and steps that contribute to good faith bargaining while at the same time protect the public from the disruption of vital public services. It is within this context that this study is seen as significant and as a contribution to the public debate over the continuation of the fact-finding step in Oregon's impasse procedure.

\section{The Implication For Urban Areas}

The implication of public sector collective bargaining and the strike for urban areas may be seen as being derived from three areas of concern: (1) financial, (2) political, and (3) provision of vital services.

First, the fiscal impact of bargaining is significant. This is because 60-75 percent (or more) of urban budgets consist of labor costs. 11 This is not to suggest that bargained wage increases are the sole, nor necessarily the most important cause of increased local governmental expenditures; but that bargained wage and salary increases have had a significant impact on urban budgets. 12 Demetrois Caraley points out in his book City Government and Urban Problems that city services are declining in quality, although 
expenditures are increasing. He attributes this to the impact of inflation, and the collective bargaining power of public employee unions. His rationale is that collective bargaining has increased labor costs while productivity has remained unchanged; the result being a decrease in the quality of services and degeneration in the quality of urban Iife. 13

Second, there is concern as to the impact of collective bargaining on the political process. Sterling spero and John M. Capozzola express their concern, in The Urban Community and Its Unionized Bureaucracies, that public employee unions are co-determining public policy by exercising their power either through the route of collective bargaining or by their increased political influence on public officials. 14 Arvid Anderson observes the same phenomena, but he expresses optimism about its impact. He believes that the collective bargaining process is "changing the establishment of government by orderly means," and has the potential of improving public service, and, therefore, society. 15 Third, is the concern over public employee strikes which can cause interruptions in the delivery of vital services to urban citizens. Robert Walsh edited an anthology on the subject of public sector collective bargaining and the strike; he entitled it, perhaps appropriately, Sorry ... No Government Today, Unions vs. City Hal1. ${ }^{16}$ Recent well published examples of such strike activity are the 1975 New York interns' strike, the 1978 Memphis firefighters' 
strike, and the 1976 New Orleans "Marti Gras" police strike. The scope of the impact of collective bargaining and the strike on urban areas can be viewed in terms of the growth in public employment, public employees organization and work stoppages over the last ten years.

In 1955 less than one million government employees were members of labor organizations; by 1965 this figure had reached $1 \frac{1}{2}$ million. However, by 1975 this figure had jumped to close to 6 milition -- a 4-fold increase in just 10 years. Proportionally the number of public workers organized is virtually double that of their private sector counterparts -- 45 percent versus 22 percent. In terms of numbers, government employees today reflect almost one out of three organized American workers, though comprising only one-sixth of the non-institutional labor force. 17

As of October $1974,4.7$ million of the nation's 9.2 million full-time state and local government employees for 51.5 percent) belonged to employee organizations. This is a dramatic increase from 1962 when only 20 percent of the then 8 million state and local employees were unionized or belonged to associations. 18

Education has the largest degree of organization, with over 72 percent of all full-time teachers in independent school districts organized by 1974. This has an affect on the total numbers of organized employees because teachers accounted for about one-third of all full-time state and local public employees. 19

In Oregon over 45.2 percent of the 621 state and local governments (except special districts) engage in collective negotiations and meet-and-confer discussions. The inclusion 
of special governmental bodies (e.g. water, port, and rural fire districts) would increase the potential number of governmental units involved in collective bargaining to 1,447.20 This study will generate more data as to the present and potential penetration of governmental units by pubIic employee organizations in oregon.

As stated before, most state laws prohibit the strike, however, work stoppages, nonetheless, have been increasing at a rapid rate. Samuel $M$. Sharkey, Jr., points out that

The public employee strike is the fastest-growing phenomenon in the labor relations field. About every three days in the first half of 1970 , some 21
city or county was hit by a walkout of its workers. Nationally, in 1960 there were 36 public sector strikes involving 28,000 workers; by 1972 this figure had increased to 381 strikes involving 130,871 workers; $^{22}$ and by 1976 (after a high of 490 strikes in 1975) 377 strikes occurred resulting in 1.7 million days of idleness and involved 167,136 employees. 23

During this period virtually every type of municipal service suffered strikes. 24 These strikes have interrupted essential services of the urban population, have caused "eleventh hour" settlements that have resulted in burdensome wage settlements, and high-handed tactics by labor and public employers alike -- much to the detriment of the urban citizen and the social fabric. ${ }^{25}$ It is within this context that this dissertation is considered significant to the urban area and within the discipline of urban studies. 
METHODOLOGY

This study is to be exploratory in method and is designed to analyze the characteristics of the fact-finding system, the major actors, their actions, and attitudes. It is structured to provide more precise information on fact-finding, to generate additional questions and isolate and explore problems regarded as important by professionals working in the field. 26 The approach is empirical but is not intended to explicitly hypothesize causal relationships nor lend itself to prediction. The methods used will allow explanation about certain aspects of Oregon's public employee collective bargaining process and its impasse procedures. 27

In short the study will try to answer the major policy question of whether the fact-finding step should be retained in Oregon's impasse resolution process. Because it is within the context of a political problem, action and change, and because the findings are formulated for utility and may be useful to Oregon policy makers, this study is considered to be social-policy research. 28

This study is multi-operational in that more than one method has been used to form the basis of the analysis. 29 The following discussion is intended to provide an overview of the methodology; details may be found in the appropriate chapters and in Appendix A, entitled: Methodological Notes. 
I. General Aggregate Data Collection

In order to gain information on the actors involved, their actions, external factors, and the association between the selected variables, data were collected from the fact-finding records of the Oregon State Conciliation Service. The study covers all fact-finding cases under the new Oregon law from 1974 through 1977 and involves twohundred and thirty-nine fact-finding cases $(n=239)$. The data were categorized into 19 variables within limits of available data, time, and monetary considerations, and their potential usefulness to this study (according to the survey research and discussion with practitioners). Analysis of the aggregate data was conducted by utilizing univariate and bivariate statistical techniques. More specific information regarding the aggregate data may be found in chapter $\mathrm{V}$, and in Appendix $\mathrm{A}$.

II. Elite or Authoritative Survey

Data generated from this method were used to translate pratitioners' knowledge and attitudes about fact-finding into a form which can be utilized as part of the literature. ${ }^{30}$ A personal interview was used to administer the survey, and the questionnaire consisted of both closed-ended and open-ended questions. The sample included mediators, fact-finders, and labor and management representatives. The sampling technique employed in the interview schedule was non-random because the universe of fact-finding cases 
was known and it was assumed that all persons and/or categories of experts were not equally experienced nor important; and, indeed, some have more insight into the process and much more impact on policy formations. ${ }^{31}$ Detailed explanation regarding these interviews may be found in Chapters VI and VII, and in Appendix A.

\section{Fact-Finding Reports}

The author gained access to fact-finding records and in many instances copies of the completed reports. These reports provided information as to the types and numbers of issues involved and the parties' actions.

\section{SUMMARY AND FORMAT}

This study will describe the fact-finding process in terms of the actors and their actions. It presents a census of the opinions of practitioners in the field to ascertain their views on the effectiveness of the process. Furthermore, it will provide conclusions as to how the process may be improved. The usefulness of this study will be in terms of its contribution to the current information base upon which further investigation can occur, and in particular, to policy makers who will be considering changes in the present state law.

The format of this study consists of seven chapters (excluding the Introduction) as outlined below:

Chapter II provides the historical background that 
places current trends in public sector collective bargaining, impasse resolution, and the strike into national context. This chapter discusses the pros and cons for public sector collective bargaining, important federal and state laws, and statistical data on the public sector unions and the role of the strike in the public sector.

Chapter III explains Oregon's public sector labor relations act and provides information regarding the present and potential penetration of governmental units by bargaining units in Oregon.

Chapter IV discusses the nature, purpose and theory of public sector impasse resolution, and places emphasis on the role of fact-finding and its place in impasse resolution. Chapter V describes Oregon's impasse procedures and provides an analysis of the fact-finding stage in terms of its use, the parties involved, their actions, and some external factors.

Chapter VI presents and analyzes the views of the neutrals (mediators and fact-finders) that are involved in Oregon's fact-finding process.

Chapter VII presents and analyzes the views of the parties (both labor and management) involved in Oregon's fact-finding process.

Chapter VIII relates the conclusions and evaluations regarding the success of Oregon's fact-finding process. Furthermore, recommendations are suggested that may aid in making the process more effective. 
CHAPTER I NOTES

${ }^{1}$ Sterling $H$. Schoen, and Raymond L. Hilgert, Cases in Collective Bargaining and Industrial Relations: A Decisional Approach, 3rd ed. (Homewood, Ill.: Irwin. 1978) . p. 5.

2 Harry H. Rains, "Dispute settlement in the Public Sector," Buffalo Law Review, 19 (1969), 279.

${ }^{3}$ Sterling Spero, and John M. Capozzola, The Urban Community and Its Unionized Bureaucracies (New York: Dunnelien, 1973), pp. 268-9.

4 Theodore W. Kheel, "Strikes and Public Employment," Michigan Law Review, 67 (March 1969), 931.

5 Thomas P. Gilroy, and Anthony V. Sincropi, Dispute Settlement in the Public Sector: The state of the Art (Washington, D.C.: GPO, 1972), p. 20 .

${ }^{6}$ Oregon Revised Statutes, Sec. 243.711 (16-17) (1979).

${ }^{7}$ Oregon Revised Statutes, Sec. 243.711 (13-19) (1979).

${ }^{8}$ Foundation for Oregon Research and Education, Collective Bargaining and Tenure in Oregon Education (Portland, ore.: Foundation for Oregon Research and Education, 1977), 51. Also see Oregon Legislative Assembly, Senate, Senate Bill 331. (As introduced) 60 th Oregon Legislative $\overline{A s s e m b} 1 y$, 1979, P. 1 .

${ }^{9}$ Jean T. McKelvey, "Fact-Finding in Public Employment Disputes: Promise or Illusion?" Industrial and Labor Relations Review, 22, No. 4 (July 1969), 532 .

10 The issue of home rule is whether cities and counties in oregon will continue to function under a grant of immunity from state legislation in those matters which are considered to be of predominate concern to local governments, as granted by the State Constitution; and therefore, whether they are subject to the provisions of the state collective bargaining law under ORS 243.650-782. 
$1 I_{\text {Alan }}$ W. Drachman, Municipal Negotiations: From Differences to Agreement, Strengthening Local Government Through Better Labor Relations. Report No. 5 (Washington, D.C.: Labor Management Relations Service, 1970), p. 3.

12 Arvid Anderson, "Public Employees and Collective Bargaining: The Changing of the Establishment," Wake Forest Law Review, 7 (March 1971), 179.

13 Demetrois Caraley, City Government and Urban Problems (Englewood Cliffs, N.J.: Prentice-Hall, 1977), pp. 8-9.

${ }^{14}$ Spero and Capozzola, p. 10.

15 Anderson, "Public Employees and Collective Bargaining," p. 188.

16 Robert Walsh, Sorry... No Government Today, Unions vs. City Hall (Boston: Beacon, 1969 .

17Edwin F. Beal, Edward Wickersham, and Philip K. Kienast, The Practice of Collective Bargaining (Homewood, Il1.: Irwin, 1976), pp. 450-51.

18 Eugene C. Hagburg, and Marvin J. Levine, Labor Relations (St. Paul: West, 1978), p. 133.

${ }^{19}$ Hagburg and Levine, p. 135.

$20 \mathrm{U}$. S. Bureau of the Census, Labor Management Relations in State and Local Governments: 1976 (Washington, D.C.: GPO, 1978), P. 52 .

${ }^{21}$ Samuel M. Sharkey, Jr., Public Employee Strikes: Causes and Effects, Strengthening Local Government Through Better Labor Relations. Report No. 7 (Washington, D.C.: Labor Management Relations Service, 1970), p. I.

22 Beal et al, p. 466 .

${ }^{23} \mathrm{U}$. S. Bureau of the Census, p. ${ }^{4}$

${ }^{24}$ Spero and Capozzola, p. 247.

${ }^{25}$ Sperc and Capozzola, p. 312. 
${ }^{26}$ Claire Selltiz et al., Research Methods in Social Relations (New York: Holt, 1964), p. 51 .

27 Hubert M. Blalock, Jr., An Introduction to Social Research (Englewood Cliffs, N.J.: Prentice-Hall, 1970), pp. 10-11.

${ }^{28}$ Howard Freeman, and Clarence C. Sherwood, Social Research and Social Policy (Englewood Cliffs, N.J.: PrenticeHall, 1970), p. 2. Also see Blalock, Social Research, pp. $59-60$.

${ }^{29}$ For a complete discussion of this approach see Donald T. Cambell, Richard D. Schwartz, and Lee Sechrest. Unobtrusive Measures (Chicago: Rand McNally, 1971), pp. $1-34$.

${ }^{30}$ Selltiz et al., p. 55 .

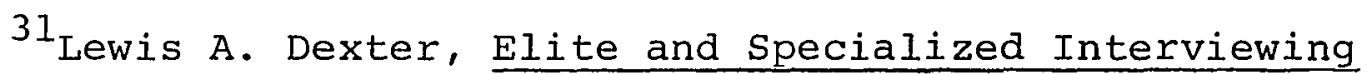
(Evanston, I1l.: Northwestern Univ. Press, 1970), pp. 7-8. Also see Hubert M. Blalock, Jr., Social Statistics, 2nd ed. (New York: McGraw-Hill, 1972), pp. 527-528. 
CHAPTER II

\section{COLLECTIVE BARGAINING IN THE PUBLIC SECTOR \\ THE NATIONAL SCENE}

The purpose of this chapter is to provide an historical background of public sector collective bargaining and a basis for comparison for the remaining chapters. This will be done by looking at the nature and importance of public sector collective bargaining and impasse resolution nationally. This chapter will deal with such basic questions as: What is collective bargaining? What are the major philosophical objections to extending collective bargaining rights to public employees? How has the growth of public employment affected employee organization? What has been the evolution and impact of Federal and state legislation permitting pubIic sector bargaining? And, finally, what role does the strike play in public sector bargaining?

The General Aspects of Collective Bargaining

The U. S. Department of Labor defines collective bargaining as:

- . negotiations in which both management and employee representatives are equal legal parties in the bargaining process and decisions are reached jointly through bilateral negotiations. The end result of collective negotiations is a mutually binding contractual agreement. 1 
The purpose of collective bargaining is to establish and maintain mutually acceptable rules and practices to guide the parties' actions and obligations in work-related situations. The resulting written agreement, or contract, becomes the basic rules governing the relationship between management and employees. Collective bargaining is an alternative to unilateral control by management. In the U. S. the parameters of collective bargaining are set by law and the parties bargain within that legal framework. The purported advantages of the process are four-fold. First, it encourages mutual understanding by both sides, thus reducing conflict and disruption of production. Second, it is a way of achieving democracy in the workplace. This is because the process allows for participation of the workers in their own governance. Third, employee organizations are a vehicle for worker political representation. Fourth, the process is a way to equalize power between employer and employees. That is, it is seen as a way to insure fairness between labor and management. 2

\section{THE PHILOSOPHICAL DEBATE OVER PUBLIC SECTOR COLLECTIVE BARGAINING}

The arguments for withholding from public employees the legal right to engage in collective bargaining have traditionally rested on three major aspects unique to the public sector: (1) the sovereign nature of the state, 
(2) the separation of powers doctrine, and (3) the structure of government financing.

\section{Sovereignty}

The sovereignty argument rests on the reasoning that in our democratic republic, ultimate power and authority (sovereignty) is vested with the people and exercised in trust by and through the government. Government, then, has sole authority that cannot be shared with a segment of the people without violating the trust for all people. Some restriction of this authority is necessary in a democracy in order to avoid oppression. 3

With respect to public employee labor relations, this logic leads to the ideological view that collective bargaining with a small portion of the people consists of reIinquishing sovereignty (authority) and the renouncement of responsibility (trust) by the government. This argument is also used for practical reasons by those who fear the impact of collective bargaining on government efficiency, management prerogeratives, and possible work stoppages. 4

Opponents of the sovereignty argument point out that the government has long exercised the traditionally recognized right to enter into contract with individuals (e.g., doctors and teachers), and to argue that government cannot contract collectively is difficult to defend. Furthermore, it is pointed out that if government really has sovereignty, 
it can do what it wishes, including bargaining with employees. 5

In spite of its inherent logic and ideological attractions, the sovereignty issue has been put to rest for practical reasons. The current position of the Federal and many state governments is that they can agree to bargain when given a mandate from the people in the form of specific legislation. Such legislation is seen as a practical means of avoiding public employee labor strife, and disruption of public services.

\section{Separation of Powers}

This technique of governing diffuses power among three levels of government (federal, state and local), and three branches at each level (executive, legislative and judicial). This is in contrast to the private sector where power to formulate and execute company policy resides with central management.

The practical problem posed by separation of powers is illustrated by the question: with whom does the employee organization bargain? The legislative branch determines pay and other economic benefits, and adopts basic civil service and personnel rules. The executive branch administrators have much discretion over administration of personnel policies. The civil service has had jurisdiction over the merit system of hiring, firing and promotion. The courts may override any of these units if misapplication of law is 
involved. Furthermore, various levels of government affect employee wages and working conditions; for example, pensions may be set at the state level for all public employees within the state, safe working conditions may be set by Federal law, while salary levels for local government employees are set at the local level.

In short, the separation of powers doctrine provided in our system adds confusion and makes collective bargaining difficult at best. 6

There are also related concerns with respect to public finance.

\section{Public Finance}

There are differences between the financial and market structures of the public and private sectors. Some think these differences are significant enough to warrant prohibition of a full transplant of the private sector collective bargaining model into the public sector. Wellington and Winter present this view in a most cogent and comprehensive manner in their book the Unions and the Cities. 7

The argument centers on the idea that in the private sector market competition restrains excessive labor demands. If increases in labor benefits are greater than productivity increases, prices of the product will increase, the final result is a decrease in quantity demanded and a decrease in employment. Also the substitution effect means that excessively high cost labor will be replaced by lower cost 
capital (machines) as management seeks their ultimate goal of profit. Furthermore, management can seek non-union labor in other parts of the country or overseas. Thus, according to this view, excessive union demands and social costs are constrained in the private sector by market forces. 8

The economic structure of the public sector, according to Wellington and Winter, differs from the private sector in two ways that lead to different results. First, the demand for city services is inelastic as the city has a monopoly on those servies; and, second, the separation of powers doctrine leads to public management being fragmented. The results are that unions have the capacity to develop an abnormal amount of power compared to other segments of the conmunity due to the following reasons. First, the union can exert political pressure (e.g. lobbying) because it is an interest group involved in the political process. Second, because the demand for public services is inelastic, the citizen (consumer) has no choice but to suffer if a strike occurs. In fact, citizens may push the public officials for a quick settlement in order to avoid discomforts caused by a strike. Third, even if a strike occurs, the citizen still has to pay for the service. Thus, substitution is not possible without undue hardship on the citizen's standard of living. Fourth, public management cannot easily search for capital to replace high cost labor because of the political problem posed by unemployment, the lack of the profit motive, as well as the inability to borrow 
satisfactory technologies. Fifth, generous pension plans may be given in order to forestall immediate budgetary problems, which, in turn, may contribute to future budget crises. Because of all of these conditions, unions in the public sector are seen to have a disproportionate share of power relative to other interest groups, which is a threat to the power structure as we have known it. 9

There is the opposing view that the differences in the economic, social, and political costs of collective bargaining in the public and private sectors are not substantial enough to warrant the two being treated differently. A summary of the major points of the argument follows. 10

First, in terms of economic power, the U.S. economic structure is oligopolistic rather than competitive; that is, a few firms dominate every major market. These firms do not engage in serious price competition, rather they compete in advertising, packaging and service. These firms deal with national unions that are usually industry-wide. Negotiations then, cover most firms, thus concessions to labor are passed on to the consumers, who have no real substitutes since most firms' labor costs and prices are similar. 11 The point is that the social costs of collective bargaining in the private sector are much more significant than many ofter consider. ${ }^{12}$ Therefore, it seems neither rational nor reasonable to deny privileges to public employees under the guise that social costs and forced redistribution of 
income through public sector collective bargaining are much more significant than in the private sector.

Second, the assumption that the profit motive is foremost in private management minds, and results in efficiency and resistance to labor, is questionable. Much research shows that although profit is a goal, maximum profit is not. Other goals such as company growth, prestige, and market stability lead management to make decisions that do not maximize profit and do not promote maximum efficiency. Thus, in the private sector, the profit motive does not promote the efficiency and resistance to labor demands to the extent that is suggested. 13

Third, the concept that private sector labor privileges would give public labor too much power reflects a particular value and bias. There are volumes of respectable data documenting the abnormal political power wielded by the business sector. Many political economists who reflect the position of J. K. Galbraith's The New Industrial State would welcome more labor power and view it as positive and "counteravailing" to abnormal management power, thus strengthening the democratic process. 14 In short, while it is true that collective bargaining would give public employees more power, the question of whether this is undesirable is open to debate.

Fourth, is the pressure of public opinion. The public's willingness to tolerate abuse of public employee unions is limited. In fact, one can further suggest that 
the separation of powers can hurt unions as much as help them because even if management negotiates too much away, public pressure could force re-negotiation.

Fifth, the potential staying power a public agency possesses can be a significant hindrance to the abuse of power by a public employee union. This is because the public agency is a monopsony (one buyer) that will still receive general tax revenues in spite of the disruption of services.

Sixth, it may be that the only way to prevent strikes in a democratic society is to embrace and improve upon the collective bargaining process, and provide acceptable alternatives to the strike. 15

Thus it is felt that the assumptions underlying the view that would deny collective bargaining rights on a financial basis are not as realistic, and the implications drawn from them not as useful as they purport to be. Certainly the issue of strike is one that has to be coped with in innovative ways to prevent serious employee unrest and disruption of public services. However, this has also become true for the private sector as the economy has become more sophisticated and private employees and unions strive to protect themselves against the full cost of a strike. 16

\section{Alternative Views}

There is the alternative view that powerful public employee collective bargaining may force many long needed 
reforms. When more is given, more can be legitimately asked in return (e.g., smaller classes may be allowed, but teacher accountability required). Faster application of technology to public services may also occur as management is forced to consider efficiency. Tenure systems may be modified or abolished. Employees of higher quality can be demanded. More professional input into decision-making can maker services better and more successful. Innovative and more responsible budgeting techniques and planning have to be adopted by management to promote fiscal stability. Finally, more involvement of employees in the process can promote overall efficiency. 17 private enterprise has already discovered that the paternalistic, hierarchical organization models are proving unable to cope with the rapidly changing, highly technological world in which we live. 18 In sum, there is good reason to think the pressures of powerful public employee collective bargaining may provide more positive than negative results. 19

This philosophical debate, however interesting, does not detract from the reality that public sector bargaining does exist and has become a topic of great interest and concern to all levels of government, the public, and labor relations experts. This interest and concern stems from the recent and rapid growth in public employment and the changes in public sector collective bargaining law and increased employee organization. 


\section{THE GROWTH OF PUBLIC EMPLOYMENT AND REASONS FOR PUBLIC EMPLOYEE ORGANIZATION}

Public Employment

Presently there are about 15.4 million civilian public employees. The state and local levels of government account for over $12.5 \mathrm{million}$ employees, and the federal level for 2.8 million. Nearly one-half (5.1 million) of the fulltime employment at the state and local level is in the education sector. 20

Local governments account for 7.6 million, or 72 percent, of the full-time employment total. This is a dramatic increase from 1967 when the local government full-time employment was $5.5 \mathrm{million}$. The average percentage increase in state and local government employment between 1967 and 1977 was 3.5 percent per year. 21 Along with this extensive and explosive change in the numbers of public sector employees, came change in their relationship with the public employers.

General Reasons for Public Employee Organizations

The increase in public employee unionism may be attributed to a series of forces that culminated in the 1960's. These forces are briefly discussed below.

First, economic inequality between private and public employees became more pronounced and obvious with the increase in demand for public services. This demand dramatically increased the numbers of public employees, many of 
whom were younger and more militant. Without an equivalent rise in public expenditure, the result was a lag in labor compensation between the public sector and private industry. Second, the effectiveness of confrontation tactics in the political sphere by the civil rights and peace movements, and organized labors' step-up in recruitment and work stoppages (such as the New York City teachers' strikes of the early '60's and the U. S. Postal strike of 1970), demonstrated to public employees that the traditional union approach could be effective in improving their lot. Third, was the general acceptance of unionism in society and the increased sympathy of the public toward extending the same labor rights to public employees as had been enjoyed by the private sector since the wagner Act of 1935. 22 Fourth, there is no doubt that John F. Kennedy's 1962 Executive Order 10988 was a landmark decision in encouraging public employee unionism, as it had spill-over effects on state and local legislation beyond the Federal level for which is was intended. 23

\section{THE EVOLUTION AND IMPACT OF PUBLIC EMPLOYEE COLLECTIVE BARGAINING LAW}

\section{Federal Law}

Executive Order 10988 was the first overall official Federal level policy on union-management relations. While some agencies such as the Postal department and TVA had well developed collective bargaining systems since the 1930's, 
most federal bargaining dates from this 1962 Executive

order. B. V. H. Schneider summarizes what appear to be the Order's most important contributions:

- . [it] formalizes practices already in existence in many departments; grants rights to employee organizations and makes these rights effective by various compulsions on management; reduces considerably the possibility of discrimination because of union activity; strengthens grievance procedures; creates a central labormanagement policy; lays down uniform rules for all departments, and clearly delineates lines of management authority and responsibility within agencies and between agencies and the civil service Commission. 24

Although E. O. 10988 was a landmark in public sector labor relations, it gave "federal unions little more than 'meetand-confer' discussion rights." 25

After several years of experience, both labor and management expressed dissatisfactions with parts of E. O. 10988. As a result of recommendations by President Johnson's 1968 "Wirtz Committee," and President Nixon's 1969 "Special Study Committe," further amendments were made. The suceeding Executive Order 11491 issued by Richard Nixon in 1969 (and further amendments in 1971) made important changes in E. O. 10988. Eugene C. Hagburg and Marvin J. Levine summarize these changes:

It insituted exclusive recognition as the only form of union recognition. It also removed from the individual federal agencies and departments much of the authority they had retained for labor management affairs during the seven years of $E$. $O$. 10988, vesting this authority instead in a coordinated federal labor relations system, with the Department of Labor now playing much the same role in the Federal sector as does the NLRB in the private sector. Executive Order 11491 also broadened 
the scope of negotiability in several areas of working conditions. It also permitted agencies to negotiate agreement providing for binding neutral arbitration of employee grievances. Other types of third party intervention now include mediation, fact-finding and binding interest arbitration supervised by the FMCS and the Federal Service Impasse Panel. 26

In 1975, Executive Order 11838 was issued was President Ford. This order further amended E. O. 11491. It broadened the scope of negotiations, and mandatory subjects of bargaining. It also changed procedure to encourage agencywide bargaining, and added vigor to negotiated grievance procedures. 27

The Impact of Federal Law

These Executive Orders encouraged union organization, and by 1975 more than one-half of all federal employees were represented by labor organizations holding exclusive representation rights. The six largest unions involved at the Federal level are the American Federation of Government Employees (AFGE); the National Federation of Federal Employees (NFFE); the National Treasury Employees Union (NTEU); the National Association of Government Employees (NAGE); the Metal Trades Council (MTC); and the International Association of Machinists (IAM). Table I indicates that by 1975 these six unions were involved in labor agreements covering approximately 3,000 recognized unions and some 960,000 federal employees.

The growth in federal sector collective bargaining can be seen in Table II. It shows that federal employees in 
TABLE I

Exclusive Recognitions and Agreements by Major Union, November 1975

\begin{tabular}{|c|c|c|c|c|c|}
\hline Union & $\begin{array}{l}\text { Recognition } \\
\text { Units }\end{array}$ & $\begin{array}{l}\text { Employees } \\
\text { Represented }\end{array}$ & $\begin{array}{l}\text { Units Under } \\
\text { Agreement }\end{array}$ & $\begin{array}{l}\text { Employees } \\
\text { Covered }\end{array}$ & $\begin{array}{l}\text { Percent } \\
\text { Covered }\end{array}$ \\
\hline 1. AFGE & 1,724 & $\begin{array}{l}670,029 \\
\text { (WG 205,496) } \\
\text { (GS 464,533) }\end{array}$ & 1,223 & 589,613 & 88 \\
\hline 2. NFFE & 690 & $\begin{array}{l}136,071 \\
\text { (WG 32,674) } \\
\text { (GS 103,397) }\end{array}$ & 521 & 116,465 & 86 \\
\hline 3. NTEU & 101 & $\begin{array}{l}83,868 \\
\text { (WG 502) } \\
\text { (GS 83,366) }\end{array}$ & 100 & 83,778 & 100 \\
\hline 4. NAGE & 333 & $\begin{array}{l}77,878 \\
\text { (WG 33,484) } \\
\text { (GS 44,394) }\end{array}$ & 236 & 72,134 & 93 \\
\hline 5. MTC & 51 & $\begin{array}{l}58,629 \\
\text { (WG 55,382) } \\
\text { (GS } 3,247)\end{array}$ & 49 & 58,560 & 100 \\
\hline 6. IAM & 96 & $\begin{array}{l}32,859 \\
\text { (WG 29,392) } \\
\text { (GS } 3,467)\end{array}$ & . 90 & 32,362 & 98 \\
\hline
\end{tabular}

TABLE II

Total Employees in Exclusive Units and Covered by Agreement, 1963-1974

\begin{tabular}{|c|c|c|c|c|c|c|c|c|}
\hline \multirow{3}{*}{ Yeara } & \multicolumn{6}{|c|}{ Employees in Exciusive Units } & \multirow{2}{*}{\multicolumn{2}{|c|}{$\begin{array}{l}\text { Employees } \\
\text { Covered by } \\
\text { Agreement }\end{array}$}} \\
\hline & \multicolumn{2}{|c|}{ Total Employees } & \multicolumn{2}{|c|}{$\begin{array}{l}\text { Wage System } \\
\text { Employees }\end{array}$} & \multicolumn{2}{|c|}{$\begin{array}{c}\text { General Schedule } \\
\text { Employees }\end{array}$} & & \\
\hline & Total & Percent & Number & Percent & Number & Percent & Number & Percen! \\
\hline 1963 & 180,000 & & & & & & & \\
\hline 1964 & 230,543 & 12 & & & & & 110,573 & 6 \\
\hline 1965 & 319,724 & 16 & & & & & 241,850 & 12 \\
\hline 1966 & $434,890^{b}$ & 21 & 226.150 & 40 & 179.293 & 15 & 291,532 & 14 \\
\hline 1967 & 629,915 & 29 & 338,660 & 54 & 291,255 & 21 & 423,052 & 20 \\
\hline 1968 & 797,511 & 40 & 400,669 & 67 & 396,842 & 28 & 556,962 & 28 \\
\hline 1969 & 842,823 & 42 & 426,111 & 72 & 416,712 & 29 & 559,415 & 28 \\
\hline 1970 & 916,381 & 48 & 429,136 & 81 & 487,245 & $\cdot 35$ & 601,505 & 31 \\
\hline 1971 & $1,038,288$ & 53 & 437,586 & 84 & 600,702 & 42 & 707,067 & 36 \\
\hline 1972 & $1,082,587$ & 55 & 427,089 & 83 & 655,498 & 46 & 753,247 & 39 \\
\hline 1973 & $1,086,361$ & 56 & 404,955 & 84 & 681,406 & 47 & 837,410 & 43 \\
\hline 1974 & $1,142,419$ & 57 & 406,000 & 82 & 736.419 & 48 & 984,553 & 49 \\
\hline
\end{tabular}

a 1963-1966 statistics are based on figures as of midyear; 1967-1974 figures are as of November.

oWage system and qeneral schedule combined dn nnt equal total due to unavailability of information.

Source: Cited in Eugene C. Hagburg, and Marvin J. Levine, Labor Relations (St. Paul: West, 1978), pp. 177-178. 
exclusive bargaining units increased from 180,000 in 1963, to $1,142,419$ by 1974. Presently over one-half of all eligible federal employees are covered by collective agreements, and there are indications that this percentage could increase within the near future. 28 Furthermore, the union activity at the federal level has had spill-over effects on the state and local levels of government.

\section{State Laws}

Before 1962 no state had passed a law granting comprehensive labor rights to public employees as guaranteed the private sector under the wagner and Taft-Hartley Acts. 29 As a result of E. O. 10988, its succeeding amendments, and the general reasons previously mentioned, a series of state laws and succeeding amendments have been passed that, unlike the federal government, resemble the private sector model provided under the National Labor Relations Act. 30

A detailed analysis and comparison of various state laws will not be presented in this dissertation. Rather, summary information is presented to show the recent development of public employee bargaining legislation in various states, the wide variety in philosophy, scope, and coverage of their laws, and the impact of such legislation on public employee unionism and bargaining.

Presently forty-one states ( 82 percent) have some type of labor relations policy that recognize all or some of pubIic employees' right to organize and be represented for the 
purpose of collective bargaining. In virtually every state in the Union and the District of Columbia there are public employee organizations engaged in collective negotiations and/or meet-and-confer discussions. 31

In the absence of Federal law or guidelines, the laws of each state vary. In 1978 Hagburg and Levine summarized them as follows:

Ten states have enacted "comprehensive" statutes covering all public employees, state, county and municipal: Florida, Hawaii, Iowa, Maine, Massachusetts, Minnesota, New Jersey, New York, Oregon and Pennsylvania . • .

Sixteen states (Connecticut, Hawaii, Iowa, Maine, Massachusetts, Minnesota, Montana, Nebraska, New Hampshire, New Jersey, New York, Oregon, Pennsylvania, Rhode Island, South Dakota, and Wisconsin) have comprehensive laws mandating broad-scope collective bargaining on wages, hours, and conditions of employment for state and local government employees . . . .

Five states (Michigan, Nevada, Oklahoma, Vermont, and Washington) have mandatory, comprehensive, fullscope bargaining laws for local government employees alone. . .

One state (Alaska) has a mandatory, comprehensive full-scope bargaining law for state employees, while leaving local government bargaining to the option 0 political subdivisions . . .

Three states (Delaware, Vermont, and Washington) have a limited form of collective bargaining for state employees which excludes wages and fringe benefits from the scope of bargaining . . .

Delaware has a comprehensive law for local government whose governing bodies opt for coverage . . - Three states (California, Kansas, and Missouri) have mandatory meet-and-confer laws covering state and local government employees . . . . A number of states have laws for selected groups such as teachers, firefighters, police and nurses. 


\begin{abstract}
The remainder of states have either permissive meet-and-confer laws or else lack labor legislation for public employees. A few, like ohio with its punitive Ferguson Act, have no strike laws but make no provision for collective bargaining. 32
\end{abstract}

The variation in state laws has resulted in a broad range of approaches to the scope of bargaining, union security, grievance disputes, neogitations, and impasse resolution. The few states' laws which have given public employees a limited right to strike (Alaska, Pennsylvania, Hawaii, Montana [nurses], Vermont and Oregon [excluding protective services]) also vary in terms of their approach to work stoppages. 33

The Impact of State Laws

The impact of state legislation on public employee unionism and bargaining is demonstrated in the Tables IIIVIII.

Table III provides membership data on the three largest unions at the state and local level. It does not include the National Education Association (NEA) which is the largest state and local employee organization. This professional association has $1.8 \mathrm{million}$ members. The largest union is the American Federation of State, County, and Municipal Employees (AFSCME), with 750,000 members, followed by the American Federation of Teachers (AFT) with 475,000 members and the International Association of Fire Fighters, with 1.75,000 members. Table III also shows that AFSCME and the AFT more than tripled membership in the 1964-1976 period. 
One of three state and local employees belong to one of these three unions. 34

TABLE III

MEMBERSHIP OF STATE AND LOCAL GOVERNMENT UNIONS, 1964-1976 (in 000's)

\begin{tabular}{lllllllll}
\hline UNION & 1964 & 1966 & 1968 & 1970 & 1972 & 1974 & 1976 \\
\hline AFSCME & 234.8 & 281.3 & 364.5 & 444.5 & 529.0 & 648.2 & 750.0 \\
AFT & 100.0 & 125.0 & 165.0 & 205.3 & 248.5 & 444.0 & 475.0 \\
NAFF & 115.4 & 115.0 & 132.6 & 146.1 & 160.3 & 171.7 & 175.0 \\
TOTAL & 450.2 & 521.3 & 662.1 & 795.9 & 937.8 & $1,263.8$ & $1,400.0$
\end{tabular}

Source: U. S. Department of Labor, Bureau of Labor Statistics, 1976, Washington Post, september 8, 1976.

Table IV provides data on the percent of full-time state and local government employees who belong to employee organizations. It shows that in 45 states between 25 and 70 percent of full-time public employees, including teachers, are organized. Table $\mathrm{V}$ indicates that distribution of organized employees is skewed heavily toward local governments, as over 3.7 million or 79 percent of the organized employees are at the local level.

Table VI considers the full-time employees organized by function and level of government. It indicates that at the local level, fire protection and teachers have the highest proportion of organized employees, with 71.6 percent and 
TABLE IV

DISTRIBUTION OF STATES BY PERCENT OF FULL-TIME EMPLOYEES ORGANIZED

\begin{tabular}{|c|c|c|c|}
\hline \multirow{2}{*}{$\begin{array}{l}\text { Percent of full-time } \\
\text { employees organtzed }\end{array}$} & \multicolumn{3}{|c|}{$\begin{array}{c}\text { Number of States by type } \\
\text { of employee }\end{array}$} \\
\hline & $\begin{array}{c}\text { A11 } \\
\text { employees }\end{array}$ & $\begin{array}{l}\text { Teachers } \\
\text { only }\end{array}$ & $\begin{array}{l}\text { A11 other } \\
\text { employees }\end{array}$ \\
\hline Total........ & 51. & 51 & 51 \\
\hline $\begin{array}{l}\text { Less than } 25 \ldots \ldots \\
25 \text { to } 39.9 \ldots \ldots\end{array}$ & $\begin{array}{r}3 \\
22\end{array}$ & $\overline{1}$ & $\begin{array}{r}22 \\
8\end{array}$ \\
\hline 40 to $54.9 \ldots \ldots \ldots$ & 11 & 6 & 12 \\
\hline 55 to $69.9 \ldots \ldots \ldots$ & 12 & 26 & 7 \\
\hline 70 to $84.9 \ldots \ldots \ldots$ & 4 & 13 & $\mathbf{2}$ \\
\hline 85 or more......... & - & 5 & - \\
\hline
\end{tabular}

- Represents zero.

${ }^{1}$ Includes the District of Columbia.

TABLE V

ORGANIZED FULL-TIME EMPLOYEES, BY LEVEL AND TYPE OF GOVERNMENT

\begin{tabular}{|c|c|c|}
\hline \multirow{2}{*}{$\begin{array}{l}\text { Level and type of } \\
\text { government }\end{array}$} & \multicolumn{2}{|c|}{$\begin{array}{c}\text { Organized full-time } \\
\text { employees }\end{array}$} \\
\hline & Number & Percent \\
\hline 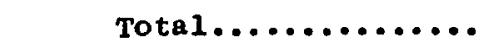 & $4,736,962$ & 100.0 \\
\hline State governments..... & 991,634 & 20.9 \\
\hline Local governments... & $3,745,328$ & 79.1 \\
\hline Counties.............. & 502,163 & 10.6 \\
\hline Municipalities......... & $1,075,727$ & 22.7 \\
\hline Townsint ps . . . . . . . . . . . & 124,208 & 2.7 \\
\hline Speclal districts...... & 119,035 & 2.5 \\
\hline School districts........ & $1,924,195$ & 40.6 \\
\hline
\end{tabular}

Source: U. S. Bureau of the Census, Labor Management Relations in State and Local Governments: 1976 (Washington, D.C.: GPO, 1978), p. 1 . 
72.1 percent respectively, of full-time employees belonging to employee organizations.

Table VII provides data on governments with a labor relations policy. It shows that 12,327 local governments (15.8 percent of the total) have labor relations policies and are engaged in collective negotiations and/or meet-andconfer discussions with employee representatives. This figure increases to 21 percent when special districts are excluded as they are not heavily involved in collective negotiation and/or meet-and-confer discussions. Table VIII provides data on state and local government labor management agreements by type and level of government. It shows that over 96 percent of the labor-management agreements occur at the local level.

In summary, presently 41 states and 9,064 local governments have 25,242 bargaining units as of October, 1976. These 25,242 bargaining units represent some 4.7 million employees or almost 50 percent of the full-time state and local government employees. School districts have the most agreements and organized employees, while special districts have the least.

The political and economic impact this recent surge in collective bargaining has had, and will have, on state and local government is not yet totally understood. One specific issue that has generated considerable concern and controversy centers on the rights of public employees to strike. 
TABLE VI

PERCENT OF FULL-TIME EMPLOYEES ORGANIZED, BY FUNCTION AND LEVEL OF GOVERNMENT

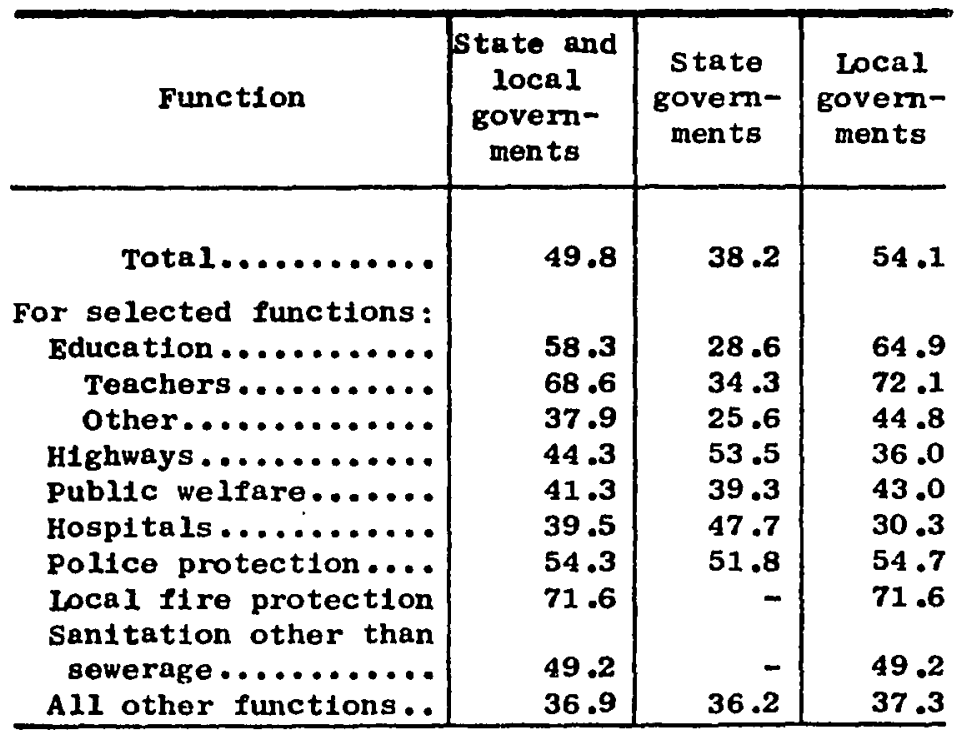

- Represents zero.

TABLE VII

GOVERNMENTS WITH A LABOR RELATIONS POLICY, BY LEVEL AND TYPE OF GOVERNMENT

\begin{tabular}{|c|c|c|c|}
\hline \multirow[t]{2}{*}{$\begin{array}{l}\text { Lovel and type of } \\
\text { government }\end{array}$} & \multirow{2}{*}{$\begin{array}{l}\text { Number of } \\
\text { govern- } \\
\text { ments }\end{array}$} & \multicolumn{2}{|c|}{$\begin{array}{l}\text { Governmenta } \\
\text { reporting a labor } \\
\text { relations policy }\end{array}$} \\
\hline & & Number & Percent \\
\hline Total........ & 78,268 & 12,368 & 15.8 \\
\hline State governments... & 50 & 41 & 82.0 \\
\hline $\begin{array}{r}\text { Local governments... } \\
\text { Counties .......... } \\
\text { Municipalities.... } \\
\text { Tounships ......... } \\
\text { Special districts. } \\
\text { School districts.. }\end{array}$ & $\begin{array}{r}78,218 \\
3,044 \\
18,517 \\
16,991 \\
23,885 \\
15,781\end{array}$ & $\begin{array}{r}12,327 \\
671 \\
2,175 \\
840 \\
654 \\
7,987\end{array}$ & $\begin{array}{r}15.8 \\
22.0 \\
11.7 \\
4.9 \\
2.7 \\
50.6\end{array}$ \\
\hline
\end{tabular}

Source: U. S. Bureau of the Census, Labor Management Relations in State and Local Governments: 1976 (Washington, D.C.: GPO, 1978), p. 1-2. 
TABLE VIII

LABOR-MANAGEMENT AGREEMENTS, BY LEVEL AND TYPE OF GOVERNMENT

\begin{tabular}{|c|c|c|c|c|c|c|}
\hline \multirow{2}{*}{$\begin{array}{l}\text { Level and Type } \\
\text { of Government }\end{array}$} & \multicolumn{2}{|c|}{ Total } & \multicolumn{2}{|c|}{$\begin{array}{l}\text { Contractual } \\
\text { agreements }\end{array}$} & \multicolumn{2}{|c|}{$\begin{array}{l}\text { Memoranda of } \\
\text { understanding }\end{array}$} \\
\hline & Number & Percent & Number & Percent & Number & Percent \\
\hline 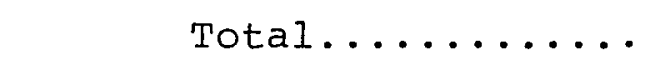 & 27,418 & 100.0 & 20,922 & 100.0 & 6,496 & 100.0 \\
\hline State governments....... & 1,052 & 3.8 & 708 & 3.4 & 344 & 5.3 \\
\hline Local governments........ & 26,366 & 96.2 & 20,214 & 96.6 & 6,152 & 94.7 \\
\hline Counties............. & 2,204 & 8.1 & 1,750 & 8.4 & 454 & 7.0 \\
\hline Municipalities........ & 6,154 & 23.8 & 4,939 & 23.6 & 1,575 & 24.2 \\
\hline Townships............ & 2,559 & 9.3 & 2,286 & 10.9 & 273 & 4.2 \\
\hline special districts..... & 1,017 & 3.7 & 705 & 3.4 & 312 & 4.8 \\
\hline School districts...... & 14,072 & 51.3 & 10,534 & 50.3 & 3,538 & 54.5 \\
\hline
\end{tabular}

Source: U. S. Bureau of the Census, Labor-Management Relations in State and Local Governments:1976, (Washington, D.C.: GPO, 1978), p. 4. 
THE ROLE OF STRIKES

Public sector strikes have been deemed inappropriate (unlawful) by the Federal and most state governments. These laws, however, have not prevented strikes, and recently it has become one of the most pressing issues in public sector labor relations. 35 The question persists whether public employees ought to have the right to strike, and if not, what substitute institutions or procedures can be developed that will lead to a balance of power between employee and employer, yet still protect the public interest and democratic process.

Theoretical Background

In the private sector the strike has long been accepted as the last stage in an exercise in power by the employees to secure increased wages and improved working conditions. It is seen as an instrument of force that brings about a balance of power between employer and employee and thus strengthens the collective bargaining process. Furthermore, it allows the parties to impose the economic costs of disagreement on one another, as the termination of work adversely affects workers' incomes and the production and sales schedule of the employer. It is the economic loss, or threat of economic loss, posed by a strike that induces both parties to alter their stances and adopt more reasonable bargaining postures. 36 
Because of market forces and the fact that strikes are seldom industry or nationwide, the spill-over costs to society are generally seen as not seriously burdensome. 37

There are, however, circumstances when private sector strikes can be detrimental to public health and safety. Because of those circumstances private sector strikes can be enjoined under the national emergency provision of the TaftHartley Act. Thus, the private sector does not have an unlimited right to strike. 38

Labor relations experts conclude that the strike is necessary in the private sector in order to balance power between employer and employee, and in order to be consistent with the democratic ideal of voluntarism. Furthermore, it is concluded that generally the strike is not an overriding burden to the public interest. However, this view does not prevail for the public sector. 39

Rationale for Prohibition of Public Sector strikes

Many of the arguments against public employee strikes follow the same reasoning as those against public employee bargaining, which were discussed earlier in this chapter. Briefly, because there are no substitutes for public services (such as water, sewer, garbage, fire, and police) the demand is inelastic, and therefore, a strike would place unusual burdens on the citizens. This gives the union power beyond what they would have in the private sector where the market prevails. Also because of the separation 
of powers, the union and public can exert political pressure on city officials. This pressure curbs the staying power of the agency involved, leads to quick settlements, and results in an imbalance of power to the union's advantage. 40

There are those who also argue that a strike (seen as an economic weapon) is not "sportsmanlike" in the public arena, where politics determines the allocation of scarce public resources. 41 And, of course, there is the sovereignty argument which stresses that public employees should not be able to strike because of possible threat to the sovereignty of the government. 42

\section{Counterarguments}

The arguments that advocate the right to strike for public employees are just as persuasive. First, in our democratic republic all citizens are to have the same opportunities, and to treat public employees as "second class" citizens is not at all consistent nor is it acceptable to democratic ideals and the people. 43 second, there are no reliable studies that show that there is a significant difference between the elasticity of public and private sector goods and services. ${ }^{44}$ Third, private sector strikes result in social and economic costs, just as public sector strikes do. Either both should be legal or illegal, as it makes little sense to separate them on the basis of social costs. 45 Fourth, the private sector does exert political pressure as well as economic pressure during strikes 
as well as in their everyday decision-making; to believe otherwise would be naive. 46 Fifth, there appears to be no marked difference between the ability of public and private sector officials to accept long strikes. 47 sixth, it is claimed that without the right to strike, a balance of power cannot be accomplished between public employees and public employers; that is, if the employer in the end can say "take it or leave it; but if you strike, you go to jail," then the whole purpose of collective bargaining is destroyed. 48

Probably because both sides' arguments contain grains of truth, middle-of-the-road positions have emerged that purport to encourage good faith bargaining by the use of some negative pressures. One such view does not condone public sector strikes carte blanc, but seeks political substitutes for the strike such as mandatory mediation, factfinding, and possible compulsory interest arbitration. 49 Another view suggests that public employee strikes should be allowed according to the degree of vulnerability of the pub1ic. For example, protective services (police and fire) should not be allowed to strike; however, teachers could. 50 Still another approach would be progressive work stoppages, where the numbers of employees and hours involved in a public employee strike would increase in specifically designated stages so as to progressively exert pressure on both sides without a severe jolt to the public. 51

Presently, only six states give a limited right to strike to public employees. Most states have adopted the 
middle-of-the-road position, legislating various combinations of "political" substitutes for the strike. Yet strike activity persists. However, before reviewing strike activity an alternative view shall be considered.

\section{An Alternative View}

In the author's opinion the mainstream of labor relations experts have bogged themselves down in a futile debate. The U. S. economic structure is highly complex, inter-related, and concentrated. The role of government is so pervasive, and there are so many relationships between the private and the public sector that it is very difficult to tell where one begins and the other ends; and therefore, where the general public interest begins and ends.

Strikes in both sectors cause externalities (spill-over effects) beyond their immediate realm (e.g., coalminers' strike of 1977-1978, or the Memphis firefighters' strike of summer 1978). Because of these externalities, it is becoming increasingly apparent that the strike, whether in the private or public sector, is an outmoded means of settling labor disputes. This is why political substitutes such as impasse resolution techniques, are being sought to replace the strike, or at least make the strike the last rather than the first resort. 52

At the root of the problem is the push by employees for more participation in the decision-making process both in the private and public sectors. Therefore, political 
substitutes for the strike are stopgap measures that help avoid chaos, but do not deal with the root of the problem. The challenge then, in the long run, is developing institutional arrangements that incorporate labor into the decision-making process, thus de-emphasizing and even eliminating the role of strike (and strike substitutes), since labor views and needs would have been recognized before major conflict arose. This view is in its infancy; however, there are public and private administration practitioners and theorists attempting to develop such policies. 53

Recent Strike Activity

As stated before, most state laws prohibit strikes; however, work stoppages have been increasing at a rapid rate. For example, nationally, in 1960 there were 36 pubIic sector strikes involving 28,000 workers; by 1972 this figure had increased to 381 strikes involving 130,871 workers, and by 1976 (after a high of 490 strikes in 1975), 337 strikes occurred resulting in 1.7 million days of idleness, and they involved 167,136 employees. 54

Table IX relates 1976 data on state and local government work stoppages. It reveals that school districts experienced the largest number of strikes, 155 or 41 percent of the total stoppages, and the most days-of-idleness $(638,878)$. Municipalities had 121 strikes or 32 percent of the total stoppages, that involved 66,839 employees and resulted in 524,515 days of idleness. 
TABLE IX

STATE AND LOCAL GOVERNMENT WORK STOPPAGES, BY LEVEL AND TYPE OF GOVERNMENT

\begin{tabular}{|c|c|c|c|c|c|c|c|}
\hline \multirow{2}{*}{ Level and type of government } & \multirow{2}{*}{$\begin{array}{l}\text { Number of } \\
\text { work } \\
\text { stoppages }\end{array}$} & \multicolumn{2}{|c|}{ Employees 1nvolved } & \multicolumn{2}{|c|}{ Duration (days) } & \multicolumn{2}{|c|}{$\begin{array}{l}\text { Days of } 1 \text { dieness } \\
\text { (employees } x \text { days) }\end{array}$} \\
\hline & & Tota1 & $\begin{array}{l}\text { Average } \\
\text { per } \\
\text { stoppage }\end{array}$ & Total & $\begin{array}{l}\text { Average } \\
\text { per } \\
\text { stoppage }\end{array}$ & Total & $\begin{array}{l}\text { Average } \\
\text { per } \\
\text { stoppage }\end{array}$ \\
\hline Total.................... & 377 & 167,136 & 443 & 3,320 & 8.8 & $1,653,791$ & $4,386.7$ \\
\hline 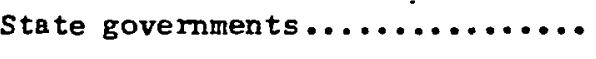 & 27 & 28,125 & 1,042 & 293 & 10.9 & 124,458 & $4,609.6$ \\
\hline Local governments............ & 350 & 139,011 & 397 & 3,027 & 8.7 & $1,529,333$ & $4,369.5$ \\
\hline Counties $\ldots \ldots \ldots \ldots \ldots \ldots \ldots \ldots$ & 40 & 13,305 & 333 & 377 & 9.4 & 163,514 & $4,087.9$ \\
\hline Municipalities...$\ldots \ldots \ldots \ldots \ldots$ & 121 & 66,893 & 553 & 716 & 5.9 & 524,515 & $4,334.8$ \\
\hline Townships.................... & 9 & 174 & 19 & 100 & 11.1 . & 1,269 & 141.0 \\
\hline Special districts.......$\ldots \ldots$ & 25 & 10,086 & 403 & 292 & 11.7 & 201,157 & $8,046.3$ \\
\hline School districts...$\ldots \ldots \ldots \ldots$ & 155 & 48,853 & 315 & 1,542 & 9.9 & 638,878 & $4,121.8$ \\
\hline
\end{tabular}

Source: U. S. Bureau of the Census, Labor Management Relations in State and Local Governments: 1976 (Washington, D.C.: GPO, 1978), p. 5 . 
Table $\mathrm{X}$ shows that education was the government function most affected by strike; however, virtually every type of service seems to have been affected to some degree.

Most work stoppages during this 12 month period occurred during the renegotiation phase of an existing labor contract and three-fourths of aIl stoppages concerned disputes of an economic and/or hours-of-work nature (similar to issues in the private sector). The most frequently-used method to resolve these disputes ( 38.3 percent of all cases) was direct negotiations between the parties. Resolution involving a third party ended 25.5 percent of all stoppages (the majority by mediation); slightly less than 15 percent of all cases were ended by court injunction, and about 21 percent by other means such as volunteer return by employees or dismissal of employees engaged in the work stoppage. 55

Given the rate and magnitude of public sector strike activity, and the resulting damage to the urban citizen and social fabric, labor relations experts have developed political procedures that are intended to replace the strike. These substitutes, referred to as impasse resolution procedures will be discussed at length in Chapter IV, after an examination of the legal setting and extent of public sector collective bargaining in Oregon in the next chapter. 
TABLE X

STATE AND LOCAL GOVERNMENT WORK STOPPAGES BY FUNCTION

\begin{tabular}{|c|c|c|c|c|c|c|c|}
\hline \multirow[b]{2}{*}{ Function } & \multirow{2}{*}{$\begin{array}{l}\text { Number of } \\
\text { work } \\
\text { stoppages }\end{array}$} & \multicolumn{2}{|c|}{ Employees Involved } & \multicolumn{2}{|c|}{ Duration (days) } & \multicolumn{2}{|c|}{$\begin{array}{l}\text { Days of } 1 \text { dleness } \\
\text { (employees } x \text { days) }\end{array}$} \\
\hline & & Total & $\begin{array}{l}\text { Average } \\
\text { per } \\
\text { stoppage }\end{array}$ & Total & $\begin{array}{l}\text { Average } \\
\text { per } \\
\text { stoppage }\end{array}$ & Total & $\begin{array}{l}\text { Average } \\
\text { per } \\
\text { stoppage }\end{array}$ \\
\hline Total.......................... & 377 & 167,136 & 443 & 3,320 & 8.8 & $1,653,791$ & $4,386.7$ \\
\hline $\begin{array}{l}\text { Education } \ldots \ldots \ldots \ldots \ldots \ldots \ldots \ldots \ldots \ldots \ldots \\
\quad \text { Teachers } \ldots \ldots \ldots \ldots \ldots \ldots \ldots \ldots \ldots \ldots \\
\text { other } \ldots \ldots \ldots \ldots \ldots \ldots \ldots \ldots \ldots \ldots\end{array}$ & $\begin{array}{r}184 \\
146 \\
98\end{array}$ & $\begin{array}{l}84,466 \\
58,230 \\
26,236\end{array}$ & $\begin{array}{l}459 \\
399 \\
268\end{array}$ & $\begin{array}{l}1,740 \\
1,355 \\
1,067\end{array}$ & $\begin{array}{r}9.5 \\
9.3 \\
10.9\end{array}$ & $\begin{array}{l}915,725 \\
595,210 \\
320,515\end{array}$ & $\begin{array}{l}4,976.8 \\
4,076.8 \\
3,270.6\end{array}$ \\
\hline 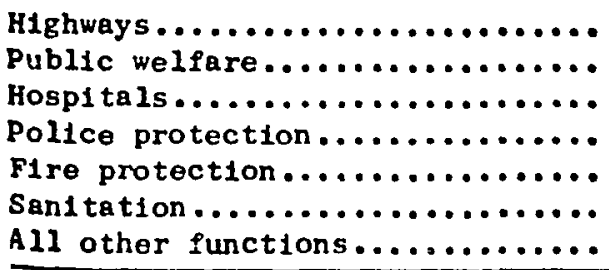 & $\begin{array}{r}65 \\
17 \\
17 \\
27 \\
21 \\
40 \\
118\end{array}$ & $\begin{array}{r}6,619 \\
7,796 \\
25,513 \\
3,004 \\
1,181 \\
3,107 \\
35,450\end{array}$ & $\begin{array}{r}102 \\
459 \\
1,501 \\
111 \\
56 \\
78 \\
300\end{array}$ & $\begin{array}{r}590 \\
195 \\
242 \\
132 \\
51 \\
239 \\
1,010\end{array}$ & $\begin{array}{r}9.1 \\
11.5 \\
14.2 \\
4.9 \\
2.4 \\
6.0 \\
8.6\end{array}$ & $\begin{array}{r}62,021 \\
87,843 \\
123,039 \\
7,430 \\
2,641 \\
18,285 \\
436,807\end{array}$ & $\begin{array}{r}954.2 \\
5,167.2 \\
7,237.6 \\
275.2 \\
125.8 \\
457.1 \\
3,701.8\end{array}$ \\
\hline
\end{tabular}

Source: U. S. Bureal of the Census, Labor Management Relations in State and Local Governments: 1976 (Washington, D.C.: GPO, 1978), p. 5 . 
CHAPTER II NOTES

${ }^{I} U$. S. Bureau of the Census, Labor Management Relations in State and Local Governments: $19 \overline{76}$ (Washington, D.C.: GOP, 1978), p. 2. Meet and confer discussions occur upon consent by the employer and resulting agreements are in the form of a memorandum of understanding, but are not legally binding.

${ }^{2}$ Harry W. Wellington, and Ralph K. Winter, Jr., The Unions and the Cities (Washington, D.C.: The Brookings Institute, 1971), $\mathrm{pp} \cdot 7-10$.

${ }^{3}$ Michael II. Moskow, Joseph J. Loewenberg, and Edward Clifford Koziara, Collective Bargaining in Public Employment (New York: Random House, 1970), pp. 16-17.

${ }^{4}$ Edward T. Beal, Edward Wickersham, and Philip Kienast, The Practice of Collective Bargaining (Homewood, Ill.: Irwin, 1976), p. 458.

${ }^{5}$ Beal et al., p. 458. Also see Moscow et al., p. 18 .

${ }^{6}$ Beal et al., pp. 460-63. Also see Moscow et al., p. 16 .

${ }^{7}$ Wellington and Winter, pp. 7-32.

${ }^{8}$ Wellington and winter, pp. 15-17.

${ }^{9}$ Wellington and Winter, pp. 29-31.

${ }^{10}$ This argument is based upon the author's nine years experience as a community college teacher in the area of political economy.

${ }^{11}$ Lloyd G. Reynolds, Labor Economics and Labor Relations, 3rd ed. (Englewood Cliffs, N.J.: Prentice-Hall, 1969), pp. 402-403. Also see John Kenneth Galbraith, The New Industrial State (Boston: Houghton, Mifflin, 1967), pp. 278-281. 
12 George W. Taylor, "Public Employment: Strikes or Procedures?" Industrial and Labor Relations Review, 20 (1967), 624. Also see David Cole, "The Search for Industrial Peace," Monthly Labor Review, 96, No. 9 (1973), 38.

13 John Kenneth Galbraith, Economics and the Public Purpose (Boston: Houghton Miffin, 1973), pp. 107-109.

${ }^{14}$ Galbriath, New Industrial State (Boston: Houghton Mifflin, 1967).

15 Theodore W. Kheel, "Strikes and Public Employment," Michigan Law Review, 67 (1969), 941.

${ }^{16}$ Theodore $W:$ Kheel et al., "Exploring Alternatives to the Strike," Monthly Labor Review, 96, No. 9 (1973), 33-66.

${ }^{17}$ Craig E. Overton, and Max S. Wortman, "One More Time: What is Collective Bargaining in the Public sector All About?" Journal of Collective Negotiations, 5 (1976), 9.

18 Warren G. Bennis, and Philip E. Slater, The Temporary Society (New York: Harper, 1968), p. 11 .

${ }^{19}$ Arvid Anderson, "Public Employees and Collective Bargaining: The Changing of the Establishment," Wake Forest Law Review, 7 (1971), 188.

$20_{U}$. S. Bureau of the Census, Public Employment in 1977 (Washington, D.C.: GPO, 1978), pp. 1-3.

${ }^{21}$ U. S. Bureau of the Census, Public Employment in 1977, pp. $1-3$.

22 Arnold M. Zack, "Impasses, Strikes and Resolutions," in Public Workers and Public Unions ed. Sam Zagoria (Englewoo d Cliffs, N.J.: Prentice-Hall, 1972), pp. 101-102.

23 Jerry Wurf, "The Uses of Fact-Finding in Public Employee Dispute Settlement: The Union View," Arbitration and Social Change, Proc. of the Twenty-Second Annual Meeting, National Academy of Arbitrators (Washington, D.C.: Bureau of National Affairs, 1970), p. 245. 
${ }^{24}$ B. V. II. Schneider, "Collective Bargaining and the Federal Civil Service," in Collective Negotiations for PubIic and Professional Employees, ed. Robert T. Woodworth, and Richard B. Peterson (Glenview, I11.: Scott-Foresman, 1969), p. 127 .

25 Eugene C. Ilagburg, and Marvin J. Levine, Labor Relations (St. Paul: West, 1978), p. 187 .

26 Hagburg and Levine, p. 187.

27 Beal et al., pp. 479-481.

${ }^{28}$ Beal et al., p. 481 and p. 487

${ }^{29}$ Some major cities such as New York City, Cincinnati, and Philadelphia have had collective bargaining relationships as early as 1939 due to the political power of local unions. See Moscow et al., p. 97.

${ }^{30}$ Sterling H. Schoen, and Raymond L. Hilgert, Cases in Collective Bargaining and Industrial Relations: A Decisional Approach, 3rd ed. (Homewood, I11.: Irwin, 1978), pp. $4-5$.

${ }^{31} U$. S. Bureau of the Census, Labor Management Relations in state and Local Governments: 1976 (Washington, D.C.: GPO, 1978), PP. 1-2.

32 Hagburg and Levine, pp. 223-225. For a comprehensive presentation of state statutes see U. S. Dept. of Labor, Summary of Public Sector Labor Relations Policies (Washington, D.C.: GPO, 1976).

${ }^{33}$ U. S. Department of Labor, summary.

${ }^{34}$ Hagburg and Levine, pp. 135-138.

${ }^{35}$ Sterling Spero, and John M. Capozzola, The Urban Community and Its Unionized Bureaucracies (New York: Dunellen, 1973), p. 239.

${ }^{36}$ Damon.W. Iarrison, Jr., "The Strike and Its Alternatives: The Public Employment Fxperience," Kentucky Law Journal, 65 (1975), 433-435. 
37 Juanita M. Kreps, Gerald G. Somers, and Richard Perlman, Contemporary Labor Economics: Issues, Analysis, and Policies (Belmont, Ca.: Wadsworth, 1974), p. 196.

${ }^{38}$ Kreps et al., pp. 196-197.

${ }^{39}$ Kreps et al., pp. 196-197.

40 wellington and winter, p. 25.

${ }^{41}$ Arvid Anderson, "Strikes and Impasse Resolution in Public Employment," Michigan Law Review, 67 (1969), 957.

42 Robert Booth Fowler, "Normative Aspects of Public Employee Strikes," Public Personnel Management, 3, No. 2 $(1974), 130$.

43 Alan Weisenfeld, "Public Employees Are Still second Class Citizens," Labor Law Journal, 20 (1969), 138-150.

44 John E. Burton, Jr., "Can Public Employees Be Given the Right to Strike?" Labor Law Journal, 21 (1970), 476.

45 Taylor, p. 644. Also Wurf, p. 101.

${ }^{46}$ Galbraith, Public Purpose, pp. 155-163.

47 Burton, p. 476 .

${ }^{48}$ Anderson, "Strikes and Impasse Resolution," pp. 947948 .

49 Taylor, p. 636 .

50 Victor E. Flango, and Robert Dudley, "Who Supports Public Employee Strikes?" Journal of Collective Negotiations, 7 (1978), 1-9. A variation on this theme would be to decide at the time whether a particular strike would significantly threaten the public interest.

${ }^{51}$ Merton C. Bernstein, "Alternatives to the strike in Public Labor Relations," Harvard Law Review, 85 (1971), 465-467. 
52 Kheel et al., "Exploring Alternatives," pp. 33-66.

${ }^{53}$ Charles L. Huges, Making Unions Unnecessary (New York: Executive Enterprises, 1976). Also see D. S. Pugh, et al., Organization Theory, ed. D. S. Pugh (Baltimore: Penguin, 1971), $\mathrm{pp} . \overline{213-269}$.

${ }^{54} \mathrm{U}$. S. Bureau of the Census, Labor Management Relations: 1976, p. 4 .

${ }^{55}$ U. S. Bureau of the Census, Labor Management Rela-
tions: 1976, p. 5 . 
CHAPTER III

THE LEGAL SETTING AND EXTENT OF PUBLIC SECTOR COLLECTIVE BARGAINING IN OREGON

In spring 1973, the Oregon State Legislature passed a comprehensive public employee collective bargaining act which included a limited right to strike. The intent of this act was to provide a uniform basis for collective bargaining among all state and local public employees while protecting the public from the interruption of government services.

The purpose of this chapter is to discuss the evolution, the purpose, the major provisions, and the major legal controversies surrounding the law. This discussion will be followed by a description of public sector employment in Oregon, and a study of the present and potential penetration of collective bargaining in Oregon's various governmental units.

Evolution of the Law

Oregon's present collective bargaining law is a result of an evolutionary process. As early as 1959, the oregon legislature passed an AFL/CIO-sponsored bill that would give extended collective bargaining rights to public employees and allow public employers to bargain with employees. This 
bill was vetoed by Governor Hatfield. Again in 1961, a permissive collective bargaining bill was introduced that provided for use of the state Conciliation Service in the event of negotiations impasse. This bill did not get out of committee. 1

In 1963, an AFL/CIO-sponsored bill was passed that became the forerunner of present Oregon law. This bill was permissive in that it did not mandate, but authorized, collective bargaining for public employees. It also authorized parties to use the State Conciliation Service in case of an impasse in negotiations and prohibited strike by public employees. ${ }^{2}$ The bill provided no new mechanics for employees to select their bargaining agent, and its permissiveness resulted in the establishment of very few bargaining units in local government, and none in the state service. ${ }^{3}$

In 1965, the Oregon Education Association (OEA), a National Education Association (NEA) affiliate, sponsored a bill to remove school teachers from the 1963 statute and place them under a meet-and-confer law. This bill became law and encouraged employee organization and collective bargaining in school districts. ${ }^{4}$ During the same session, the legislature passed an amendment to the 1963 law that was backed by the oregon state Employees Association (OSEA). This act required any unit of government that had a civil service commission to establish and administer procedures for certification and elections of bargaining units. ${ }^{5}$ This in effect mandated collective bargaining in the state 
government and five counties that had civil service commissions. By mid 1966, OSEA had established itself as bargaining representative for about 9,400 state employees in 37 agency-wide units, and had arrived at collective bargaining agreements with the state. However, collective bargaining at the local level was a confused issue, and only one civil service city (Milwaukie) adopted procedures under the 1965 amendment. ${ }^{6}$ The more populous cities such as Portland and Eugene, adopted their own ordinances covering public employee collective bargaining.

In 1969, the State Civil Service Commission was abolished, and state-level personnel management was centralized in a personnel division under the Governor's Executive Department. A new agency, the Public Employees Relations Board (PERB), was given responsibility to administer quasijudicial review functions over the administration of the merit system. PERB was also given responsibility for administering the collective bargaining law for state employees and for local government who chose to place themselves under state law. PERB also inherited the state conciliation Service from the State Bureau of Labor. ${ }^{7}$ Further proposed amendments included changes in definitions of "collective bargaining" and "employment relations" similar to the TaftHartley Act. Also PERB was to have jurisdiction over unfair labor practice and contract violations complaints, as well as settlement of negoitations impasse, including factfinding with recommendations. A last minute change in the 
definition of "public employer" resulted in the bill being interpreted as permissive by local governments. The impact was that collective bargaining at the local level was not considerably stimulated. 8

The 1971 legislature broadened the subjects that were covered under the teachers' meet-and-confer law, and placed classified school employees under that law. By this time several local governments were bargaining with their employees under a variety of local ordinances, while some local governments refused to bargain with their employees. 9

\section{The Redden Committee}

Because of the lack of uniformity among city and county ordinances, and the recognition that public sector collective bargaining was here to stay, Governor McCall appointed a three-man task force in 1972 to study the problem of collective bargaining at the state and local level and to develop legislative recommendations for the 1973 legislature. 10

This task force (The Redden Committee) presented its recommendations in the form of House Bill 2263 (H. B. 2263), to the House and senate Committees on Labor and Industrial Relations in the spring of 1973. The task force's most significant proposed changes in the 1969 law were: First, that all public employees and all state and local governments (including school and special districts) would have the right to bargain and enter into bargaining agreements. This 
reflected the committee's thought that public employees "should be welcomed to the world of the first class citizen" and that a single inclusive act would produce more rational methods to deal with public employee relations. ${ }^{1}$ second, a number of unfair labor practices were specified and a board granted authority to rule on complaints and seek court enforcement of its orders. Third, the machinery was provided for bargaining-unit determination and impasse resolution. The committee proposed positive legislation as the "best way to harness and direct the energies of public employees, eager to have a voice in their working conditions." 12

H. B. 2263 emerged from the house committee considerably amended and liberalized. It provided for major changes in the 1969 law and reflected considerable research on other state laws (in particular Michigan, Wisconsin and Hawaii). It incorporated a very progressive labor relations philosophy and procedure because it used much language from the Taft-Hartley Act. 13

By summer 1973, the legislature had passed H. B. 2263 with amendments that included a limited right to strike for all public employees except those in protective services. It was considered by many labor relations experts to be a model law. An attempt was made to refer the law to the publi.c for a referendum vote; however, the attempt failed. The law became effective in october, 1973. 14 
The Purpose of the Law

The intent of the law appears in the legislature's policy statement under ORS 253.656. First, it declares that the people of the state have a fundamental interest in the development of harmonious relations between government and its employees. Second, it is recognized that collective bargaining is one way to alleviate labor problems. Third, it embraces the concept that in both the private and public sectors protection of labor rights and negotiations by law safeguards the public from the impact of uncontrolled labor strife. Fourth, it states that a redress of power between public employers and employees was in order. Fifth, it accepts the state's obligation to protect the public from disruption of governmental services. Sixth, it is intended to provide a uniform basis for organizaticn recognition, negotiations and impasse resolution. 15

In summary, the Oregon State Legislature passed a law that provides a uniform basis for all public employers and employees to engage in collective bargaining as a means to promote improvement of labor relations and to protect the public interest. The purpose of the following section is to discuss the major features of the law.

\section{Major Provisions of Oregon Law}

The law grants the Employee Relations Board (ERB) the power to administer the law. The composition of the board 
was changed by an amendment in June, 1977. This amendment (H. B. 2676) was in response to the need for full-time ERB members, in lieu of part-time members, to handle the increased workload and provide more professional and careful consideration of the decisions required by the board. The amendment reduced the ERB from five part-time to three fuI1time members, who are trained or experienced in labor management relations. It also requires the Governor to consider the interests of labor, management, and the public in making appointments of the members and chairpersons. 16

Representation Matters. If a question of representation exists, and a valid petition from an employer, a labor organization or public employees has been received, the ERB must conduct a hearing to determine the bargaining unit, conduct secret ballot elections, and certify the winner as the exclusive bargaining representative. The hearings may be waived if all parties agree to the bargaining unit and consent to an election. 17

In order to request an election, a labor organization must represent 30 percent of the employees. Any other union wishing to be on the ballot must represent at least 10 percent of the employees. 18 The law prohibits an election for one year from the time of the last election in order to insure reasonable stability. 19

Unfair Labor Practices. The law charges the ERB to investigate any complaint of an unfair labor practice committed by a labor organization or a public employer. If, 
in the board's opinion, such a practice may exist, a hearing is held within 20 days of the written complaint. The board, after the hearing, has the power to issue orders of cease and desist, reinstate employees with or without back pay, or dismiss the complaint. 20

Negotiation and Scope of Bargaining. The law requires the certified labor organization and the public employer to meet at reasonable times and bargain in good faith over economic benefits and employment relations. 21 "'Employment relations' includes, but is not limited to, matters concerning monetary benefitș, hours, vacations, sick leave, grievance procedures, and other conditions of employment." 22

The law does not attempt to establish negotiation time limits that coincide with the July to July fiscal year budgetary deadlines that are required by laws of public employers. Problems relating to this will be discussed in later chapters.

Miscellaneous Provisions. The law provides that the parties may agree to submit to binding arbitration on grievances and conditions and terms of a contract. 23 It mandates a dues check off and permits fair-share agreements and the agency shop. 24

Impasse Resolution. The law sets up mandatory steps for impasse resolution should collective negotiations break down. The steps follow the familiar pattern of mediation, fact-finding, and a cooling-off period. If these efforts are unsuccessful they are followed by compulsory arbitration 
for the protective services, or strike for all other public employees. Mediation services are provided by the State Conciliation Service which is under the auspices of ERB. Fact-finding and arbitration services are paid for by the parties. The Conciliation Service maintains fact-finding and arbitration 1 ists and administers the selection process when such services are needed. 25 Figure 1 is a flow chart showing the basic steps in the impasse resolution process. Details of this process will be discussed in chapter $V$.

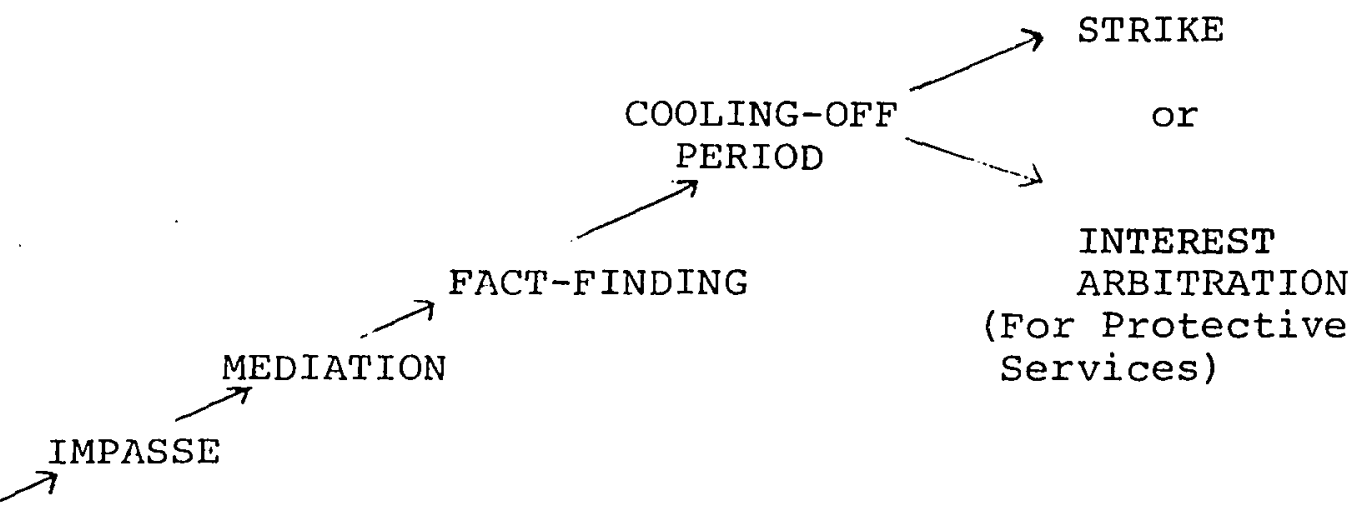
NEGOTIATIONS

Figure 1. The Oregon Impasse Resolution Process

Strike. Oregon's law grants a limited right to strike to all public employees, except those in the protective services (police, fire, and institutional guards). Thirty days after a fact-finding report has been made public, and 10 days after notice of intent to strike has been submitted, employees may strike. 26

When a strike is occurring or is about to occur, a public employer may petition the circuit court for an injunction, provided it is demonstrated such a strike is a "clear 
and present danger or threat to the heaith, safety or welfare of the public." If the court issues an injunction, it must submit the dispute to final and binding arbitration within 10 days of the injunction. 27

The law prohibits certain types of strikes. Employees not in the appropriate bargaining unit involved in the dispute are prohibited from striking. Employees cannot strike without first utilizing the impasse procedure (mediation, fact-finding, the 30 day cooling-off period, and 10 day intent to strike notice). Also, strikes over a grievance of unfair labor practice are prohibited. ${ }^{28}$

Major Legal Controversies Surrounding the 1973 Law - The Home Rule Issue

Application of the law has resulted in much controversy. The controversy centers on the home rule issue. The Oregon Constitution prohibits the State Legislature from enacting, amending or repealing any city charter, ${ }^{29}$ and prohibits state legislation on matters of "county concern."30 In Ileinig v. Milwaukie, the oregon supreme court held that the State Constitution prevents state legislature enactment on matters of "local concern." This decision invalidated a statute which would have required all cities to establish a civil service system for firemen. "Unfortunate${ } y$, the opinion provides minimal and conflicting criteria for determining 'local concern' in other situations." 31 This case has provided a basis for local governments to 
challenge the application of the state Legislature's 1973 collective bargaining act.

In 1974, the City of Beaverton filed suit challenging application of the state collective bargaining law to cities and counties that have home rule status. The city argued that although its local labor relations ordinance was in conflict with state law, collective bargaining was a matter of local concern and that the state law was unconstitutional as it applicd to a city. The case was remanded back to the Limployees Relations Board in order to attempt to determine what areas of labor relations are of predominantly local concern and the ones that are of state-wide concern. 32

ERB conducted and completed hearings of this subject by April, 1976. However, an ERB ordex was not issued due to another supreme Court decision to set aside, on technical grounds, a similar case involving the city of Hermiston. This case is still pending. 33

During January 1978, the Supreme Court ruled on another case (involving employee pensions) that established a new standard with respect to home rule when, in LaGrande/Astoria v. PERB, it was held that

- a state law with social, cconomic, or other regulatory objectives would prevail over local law if it docs not interfere with the local community's freedom to choose its own political form. 34

The court agreed to reconsider this case and heard oral argument. Since that reconsideration the decision has been seen to address itself to the home rule issue as it applies 
to retirement and insurance for police and fire workers, and not to collective bargaining. 35

Because this series of supreme Court decisions did not result in a definitive ruling, many ERB rulings involving unfair labor practices and representation disputes were not issued because until the home rule issue was resolved, any such rulings would be opinion and non-binding. As a result, oregon's collective bargaining law is accepted only by those home rule counties and cities that want to accept the law. However, ERB acts as if it has authority and exercises its powers unless its actions are appealed. Some home rule counties and cities have utilized the mediation and factfinding services of ERB by mutual agreement of the parties, and on a voluntary basis. 36

Because no outstanding court ruling has decreed this law unconstitutional, the ERB recently issued a backlog of orders to several home rule cities in cases involving unfair labor practices and representation disputes. If these orders are challenged or ignored by the cities, the court will probably be asked again to rule on the constitutionality of the law. ${ }^{37}$ In the meantime, Jabor has worked and continues to work within these constraints until the issue is settled.

The consensus of local officials is that their major concern is not collective bargaining rights or the right to strike, but rather, the portion of the law which mandates compulsory binding arbitration for police and fire 
services. 38 Although these court actions have not stopped organizational growth and effective collective bargaining, they may have been slowed in areas such as special districts and small cities. Furthremore, until the court makes a definite ruling on the constitutionality of the law, public employee labor policies will not be as comprehensive nor as consistent as the legislature intended.

\section{OREGON'S PUBLIC SECTOR}

\section{Composition}

Following the national trend, public employee organization and collective bargaining have been increasing in oregon since the passage of the state's comprehensive bargaining statute in 1973.

Table XI provides data on public employment in oregon by level of government and function from 1974 through 1977. While the total state and local government employment increased by 16,700 through these years, or almost 12 percent, that pattern of increase was not uniformly found in all areas.

Non educational employment at the state and local level showed the greatest growth during this period, with increases of 19 percent and almost 18 percent respectively. Educational employment grew just over 2 percent at the state level and almost 9 percent at the local level; both are below the 12 percent average growth for all public 
TABLE XI

NUMBERS OF OREGON PUBLIC EMPLOYEES: BY LEVEL OF GOVERNMENT AND FUNCTION DECEMBER 1974 - DECEMBER 1977*

\begin{tabular}{|c|c|c|c|c|c|}
\hline \multirow[b]{2}{*}{$\begin{array}{l}\text { Level of } \\
\text { Government }\end{array}$} & \multicolumn{4}{|c|}{ YEAR } & \multirow{2}{*}{$\begin{array}{l}\text { Percen- } \\
\text { tage } \\
\text { Change } \\
74-77\end{array}$} \\
\hline & 74 & 75 & 176 & 177 & \\
\hline State Total. & 46,800 & 49,900 & 51,000 & 52,000 & 11.18 \\
\hline State Education & 22,100 & 22,900 & 23,300 & 22,600 & 2.38 \\
\hline $\begin{array}{l}\text { State Non- } \\
\text { Education }\end{array}$ & 24,700 & 27,000 & 27,700 & 29,400 & $19.0 \%$ \\
\hline Local Total & 95,000 & 100,300 & 103,200 & 106,500 & $12.1 \%$ \\
\hline Local Education & 60,300 & 62,900 & 64,800 & 65,600 & $8.7 \%$ \\
\hline $\begin{array}{l}\text { Local Non- } \\
\text { Education }\end{array}$ & 34,800 & 37,400 & 38,400 & 40,900 & $17.5 \%$ \\
\hline $\begin{array}{l}\text { State and Local } \\
\text { Total }\end{array}$ & 141,800 & 150,200 & 154,200 & 158,500 & 11.78 \\
\hline Federal & 26,200 & 26,900 & 27,004 & 27,000 & $3.0 \%$ \\
\hline
\end{tabular}

Source: Phone interview with Don Stewart, Chief, Research and Statistics, Oregon State Employment Division, 11 April 1978 .

*Annual average including part-time, temporary, CETA and seasonal employees. 
employment in Oregon. This perhaps reflects the passage of the post WW-II baby boom and the changing composition of demand for educational services. This also may be one factor that is contributing to the relatively high degree of public sector unionism in the education sector of Oregon that will be explained in the next section.

In summary, Tably XI shows that Oregon's public sector labor relations law covers over 150,000 public employees; some 50,000 are at the state level, while over 100,000 are at the local level. 39 By function, education represents the greatest number of those employees, as 62 percent of local and 44 percent of state employees are involved in the education sector.

\section{Organized Employees}

Recent Bureau of Census studies show a substantial number of Oregon's public employees are organized. Table XII presents data on the percent of Oregon public employees who belong to labor organizations. These statistics show that 57.5 percent of state full-time equivalent (FTE) employees and 61.8 percent of local FTE employees were organized in 1975, whereas the percentages were 50.1 percent and 66.3 percent in 1976. This reflects a 9.5 percent decline in state and an 8.2 percent gain at the local level. The largest percent increase in organization during the 1975-76 period came in special districts at the local level -- over 20 percent increase -- and in municipalities over 15 percent. 
TABLE XII

STATE AND LOCAL GOVERNMENT ORGANIZED EMPLOYEES, BY TYPE OF GOVERNMENT, OCTOBER 1975 AND OCTOBER 1976

\begin{tabular}{|c|c|c|c|c|c|c|c|c|}
\hline \multirow{3}{*}{ State and type of governeent } & \multirow{2}{*}{\multicolumn{3}{|c|}{ Total full-tine exploysent }} & \multicolumn{5}{|c|}{ Full-tine employees tho belong to an employee organtzation } \\
\hline & & & & \multicolumn{2}{|c|}{ October 1975} & \multicolumn{2}{|c|}{ Oetober 1976} & \multirow{2}{*}{$\begin{array}{l}\text { Percent } \\
\text { change } \\
\text { October } \\
1975 \text { to } \\
\text { October } \\
1976\end{array}$} \\
\hline & $\begin{array}{c}\text { October } \\
1975\end{array}$ & $\begin{array}{c}\text { October } \\
1976\end{array}$ & $\begin{array}{l}\text { Percent } \\
\text { chsnge }\end{array}$ & Sumber & Percent & Number & Percert & \\
\hline \multicolumn{9}{|l|}{ OREGON } \\
\hline 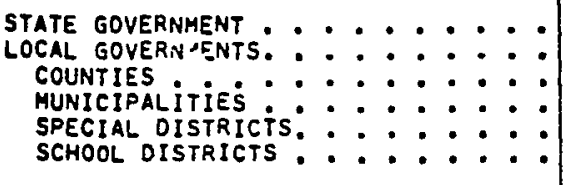 & $\begin{array}{ll}34 & 386 \\
76 & 707 \\
12 & 929 \\
12 & 647 \\
5 & 619 \\
45 & 512\end{array}$ & $\begin{array}{ll}35 & 724 \\
77 & 290 \\
12 & 608 \\
12 & 336 \\
6 & 006 \\
46 & 340\end{array}$ & $\begin{array}{r}3.9 \\
0.8 \\
-2.5 \\
-2.5 \\
6.9 \\
1.8\end{array}$ & $\begin{array}{rr}19 & 780 \\
47 & 373 \\
5 & 867 \\
6 & 443 \\
2 & 554 \\
32 & 509\end{array}$ & $\begin{array}{l}57.5 \\
61.8 \\
45.4 \\
50.9 \\
45.5 \\
71.4\end{array}$ & $\begin{array}{rr}17 & 896 \\
51 & 259 \\
5 & 526 \\
7 & 417 \\
3 & 076 \\
35 & 240\end{array}$ & $\begin{array}{l}50.1 \\
66.3 \\
43.8 \\
60.1 \\
51.2 \\
76.0\end{array}$ & $\begin{array}{r}-9.5 \\
8.2 \\
-5.8 \\
15.1 \\
20.4 \\
8.4\end{array}$ \\
\hline
\end{tabular}

Source: U. S. Bureau of Census, Labor Management Relations in State and Local Governments: 1976 (Washington, D.C.: GPO, 1978), P. 15 .

Note: Data are Bureau of Census estimates. 
The latter increase is especially significant given the 2.5 percent decrease in municipal employment for the same period.

Table XIII compares organized employees by function. This table shows that in Oregon, teachers were the most organized at the local level in 1976 (78.8:), followed by firefighters $(68 \%)$ and policemen (61\%). At the state level the most organized workers in 1976 were non-teaching education workers (72.1\%), followed by highway personnel (66.4\%), hospital employees (53.7\%) and teachers (51.1\%). The greatest growth in employee organization at the local level in the 1975-76 period was in hospitals with an incredible 254 percent increase! At the state level, the greatest gain was in police protection (state police) -- 66.7 percent; all other functions experienced a decline in employee organization.

Table XIV provides an overview of the impact of collective bargaining in oregon. It shows the state and local governments with labor relations policies, bargaining units and represented employees by type of government in October, 1976. Of the 1,447 governments in Oregon (including school and special districts), 312 are engaged in collective negotiations and/or meet-and-confer discussions. This involves 612 bargaining units, and results in 624 labor agreements. These data reveal the significance of public sector collective bargaining in oregon. In order to assess the potential 
TABLE XIII

STATE AND IOCAL GOVERNMENT ORGANIZED EMPLOYEES, BY FUNCTION, OCTOBER 1975 AND OCTOBER 1976

\begin{tabular}{|c|c|c|c|c|c|c|c|c|}
\hline \multirow{3}{*}{ state and type of governacot } & \multirow{2}{*}{\multicolumn{3}{|c|}{ Totel sul1-t,10e enployment }} & \multicolumn{5}{|c|}{ Fuld-tide exployees tho belong io an employce orkenization } \\
\hline & & & & \multicolumn{2}{|c|}{ October 1973} & \multicolumn{2}{|c|}{ October 3976} & \multirow{2}{*}{$\begin{array}{l}\text { Percent } \\
\text { chense, } \\
\text { october ig7s } \\
\text { to } \\
\text { October } 1976\end{array}$} \\
\hline & $\begin{array}{c}\text { October } \\
1975\end{array}$ & $\begin{array}{c}\text { October } \\
1976\end{array}$ & $\begin{array}{l}\text { Percent } \\
\text { changes }\end{array}$ & Rumber & Percont & Nu=ber & Percent & \\
\hline OREGOH & & & & & & & & \\
\hline 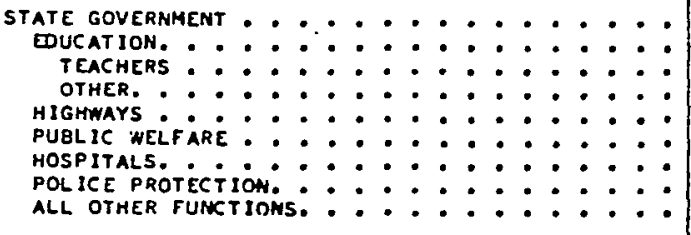 & \begin{tabular}{rr|}
34 & 386 \\
9 & 917 \\
4 & 384 \\
5 & 533 \\
3 & 698 \\
3 & 440 \\
4 & 520 \\
1 & 115 \\
11 & 688
\end{tabular} & \begin{tabular}{rr|}
35 & 724 \\
9 & 921 \\
4 & 292 \\
5 & 629 \\
3 & 540 \\
3 & 902 \\
4 & 642 \\
1 & 155 \\
12 & 564
\end{tabular} & $\begin{array}{r}3.9 \\
12 . \\
-2.1 \\
1.7 \\
-4.3 \\
13.4 \\
2.5 \\
3.6 \\
7.5\end{array}$ & $\begin{array}{rr}19 & 780 \\
5 & 594 \\
2 & 262 \\
4 & 332 \\
2 & 533 \\
1 & 967 \\
2 & 802 \\
5 & 3 \\
5 & 801\end{array}$ & $\begin{array}{l}57.5 \\
66.5 \\
51.6 \\
78.3 \\
68.5 \\
57.2 \\
61.9 \\
00.3 \\
50.3\end{array}$ & $\begin{array}{rr}17 & 896 \\
6 & 255 \\
2 & 195 \\
4 & 060 \\
2 & 350 \\
1 & 593 \\
2 & 491 \\
5 & 5 \\
5 & 202\end{array}$ & $\begin{array}{l}50.1 \\
63.0 \\
51.1 \\
72.1 \\
66.4 \\
40.8 \\
53.7 \\
0 . .4 \\
41.4\end{array}$ & $\begin{array}{r}-9.5 \\
-5.1 \\
-3.0 \\
-6.3 \\
-7.2 \\
-19.0 \\
-11.0 \\
66.7 \\
-11.5\end{array}$ \\
\hline 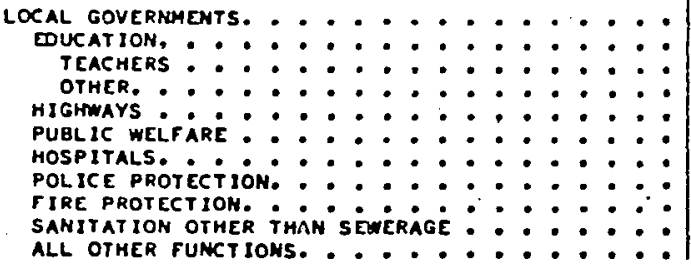 & $\begin{array}{ll}76 & 707 \\
45 & 512 \\
31 & 795 \\
13 & 717 \\
3 & 635 \\
474 \\
2 & 004 \\
4 & 310 \\
2 & 722 \\
269 & 269 \\
17 & 786\end{array}$ & \begin{tabular}{ll|}
77 & 290 \\
46 & 340 \\
32 & 828 \\
13 & 512 \\
3 & 575 \\
& 484 \\
1 & 693 \\
4 & 079 \\
2 & 650 \\
18 & 330 \\
18 & 130
\end{tabular} & $\begin{array}{r}0.8 \\
1.8 \\
3.2 \\
-1.5 \\
-1.7 \\
2.1 \\
-15.5 \\
-5.9 \\
-2.6 \\
25.0 \\
2.0\end{array}$ & $\begin{array}{ll}47 & 373 \\
32 & 509 \\
23 & 479 \\
9 & 030 \\
2 & 148 \\
120 \\
164 \\
2 & 672 \\
2 & 023 \\
280 \\
7 & 557\end{array}$ & $\begin{array}{l}62.8 \\
71.4 \\
73.8 \\
65.8 \\
59.1 \\
25.3 \\
8.2 \\
62.0 \\
74.3 \\
68.2 \\
42.5\end{array}$ & $\begin{array}{ll}51 & 250 \\
35 & 240 \\
25 & 962 \\
9 & 378 \\
2 & 081 \\
& 160 \\
& 581 \\
2 & 483 \\
1 & 803 \\
1909 \\
1 & 712\end{array}$ & $\begin{array}{l}66.3 \\
76.0 \\
78.8 \\
69.4 \\
58.2 \\
33.1 \\
34.3 \\
60.0 \\
68.0 \\
60.3 \\
48.0\end{array}$ & $\begin{array}{r}8.2 \\
8.4 \\
10.1 \\
3.9 \\
-3.5 \\
33.5 \\
254.3 \\
-7.3 \\
-10.9 \\
10.6 \\
15.3\end{array}$ \\
\hline
\end{tabular}

Source: U. S. Bureau of Census, Labor Management Relations in State and Local Governments: 1976 (Washington, D.C.: GPO, 1978), D. 28 .

Note: Data are Bureau of Census estimates. 
TABLE XIV

STATE AND LOCAL GOVERNMENT LABOR RELATIONS POLICIES, BARGAINING UNITS, AND REPRESENTED EMPLOYEES, BY STATE AND TYPE OF GOVERNMENT: OCTOBER 1976

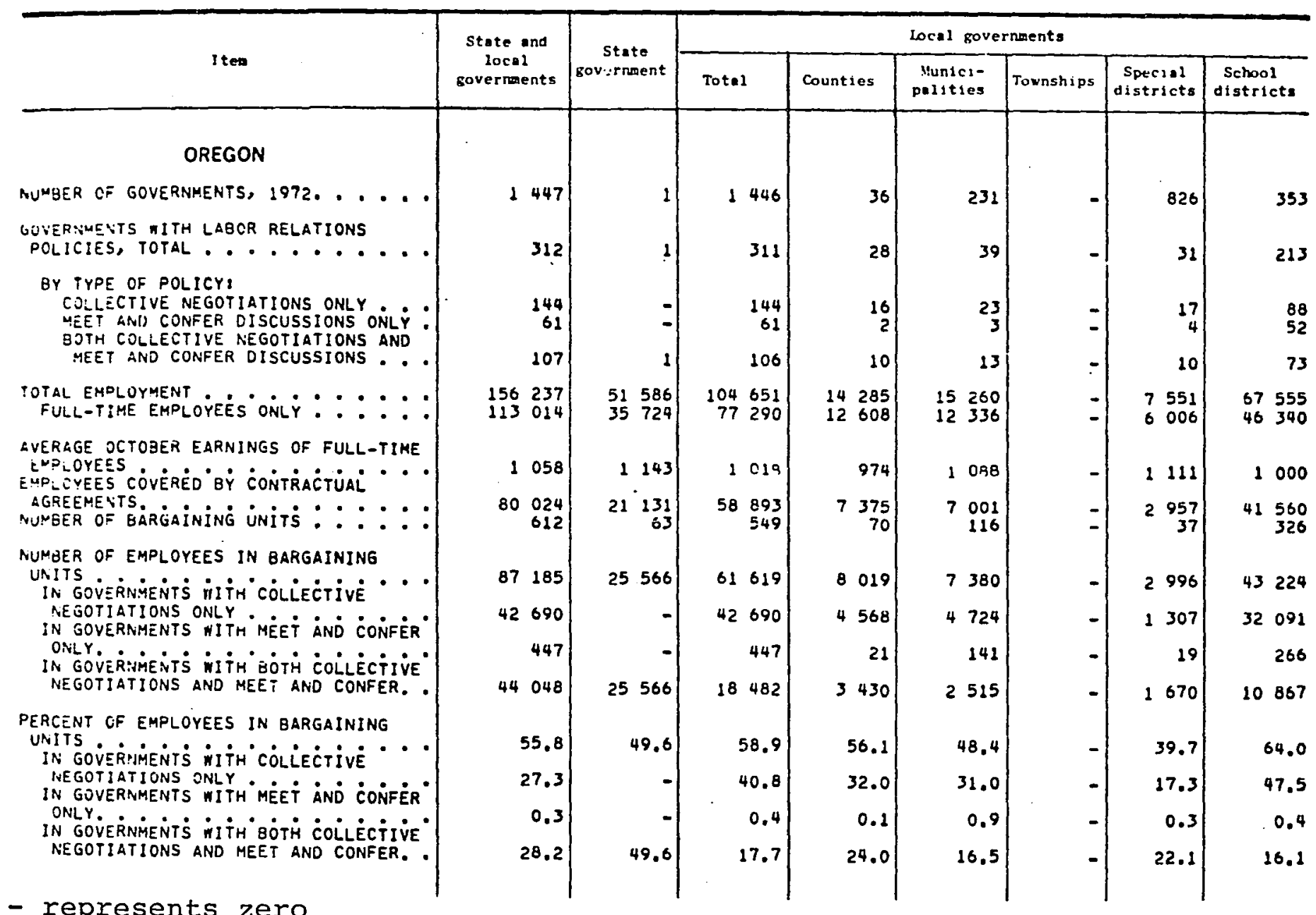

Source: U. S. Bureau of the Census, Labor Management Relations in State and Local Governments: 1976 (Washington, D.C.: GPO, 1978), p. 52 .

Note: Data except for bargaining units are census bureau estimates. 
number of possible bargaining units, an impact or penetration study has been generated.

\section{Impact study}

To aid in assessing the importance and potential impact of collective bargaining in oregon, it is useful to compare actual bargaining units with the number of possible bargaining units. Because there is no centralized bureau in Oregon that calculates this information, and because census data are usually two years out of date, and because census data are based upon samples rather than a full count, this study has provided estimates of penetration information. The information sought is the potential numbers of bargaining units by level of government, considering functions at each level, and the percent of those potential bargaining units that have been organized. The percentage is referred to as the percent or degree of penetration.

Some assumptions about the number of potential collective bargaining units in each type of governmental unit have been made in order to calculate the degree of penetration. These assumptions are based upon the practical knowledge of experienced practitioners in Oregon labor relations and on the population of each unit. Furthermore, actual bargaining unit data is based upon the most recent Oregon figures, practitioners' estimates, and in some cases the 1976 Bureau of Census report. 40 
Assumptions are made regarding the potential number of bargaining units in state, county, city, school district, IED, community college, and higher education, based on functions in each of these government. units.

1. The state has an actual 83 bargaining units with a potential of 108 units.

2. Counties are categorized by population size into three groups and have potential units as follows:

Counties

under 50,000

over 50,000

Within SMSA's
Number of Bargaining Units

- 2 units (e.g. sheriff and all other)

- 4 units minimum and 5 units maximum (e.g. sheriff, nurses, parks, roads, clerical, and health)

- 5 units minimum and 7 units maximum (e.g. sheriff, parks, roads, clerical, health, corrections, and court employees)

3. Cities are categorized by population and have potential units as follows:

\begin{tabular}{|c|c|c|}
\hline Cities & & Number of Bargaining Units \\
\hline under 1,500 & - & zero units \\
\hline $1,500-2,500$ & - & 1 unit \\
\hline $2,500-10,000$ & - & 2 units (fire and police) \\
\hline $10,000-50,000$ & - & $\begin{array}{l}4 \text { units minimum and } 5 \text { units } \\
\text { maximum (e.g. fire, pólice, } \\
\text { parks, roads, and clerical) }\end{array}$ \\
\hline Salem $(83,170)$ & - & $\begin{array}{l}4 \text { units minimum and } 6 \text { units } \\
\text { maximum (e.g. fire, police, } \\
\text { parks, roads, and clerical) }\end{array}$ \\
\hline
\end{tabular}




\begin{tabular}{|c|c|c|}
\hline Cities & & Number of Bargaining Units \\
\hline Eugene $(100,450)$ & - & $\begin{array}{l}4 \text { units minimum (e.g. fire, } \\
\text { police, parks, roads and } \\
\text { clexical) }\end{array}$ \\
\hline ortland $(384,500)$ & - & (actual) \\
\hline
\end{tabular}

4. School Districts are categorized by Average Daily Membership (ADM) :

\begin{tabular}{|c|c|c|}
\hline Districts & & Number of Bargaining Units \\
\hline ADM under 9,000 & - & 2 units (faculty and staff) \\
\hline ADM over 9,000 & - & $\begin{array}{l}2 \text { units minimum and } 3 \text { units } \\
\text { maximum (e.g. faculty, staff } \\
\text { and patrol) }\end{array}$ \\
\hline Portland & - & $\begin{array}{l}\text { has an actual of } 4 \text { units with } \\
\text { a potential of } 6 .\end{array}$ \\
\hline
\end{tabular}

5. Intermediate Education Districts (IED) are categorized by the population of the counties in which they are located: Districts Number of Bargaining Units
In counties under $50,000 \quad-\quad 1$ unit
In counties over $50,000 \quad-\quad 2$ units
Within SMSA's _ $\quad 2$ units minimum and 3 units maximum

6. Community Colleges have a potential of two units (faculty and staff).

7. Higher Education (which is included in the state figures) has a minimum and maximum of two units per campus (faculty and staff) in the state colleges, and a maximum of five units per campus in the universities (e.g. faculty, 
staff, graduate students, supervisors, and other miscellaneous groups such as T.V. operators, guards or nurses).

8. Special Districts are categorized by the population of the area in which they exist.

Within SMSA's

All others
- 1 unit minimum and 2 units maximum. (This is conservative as some have much more than that. e.g., Port of Portland negotiates 8 contracts)

-1 unit

\section{Data Sources}

The categories and numbers of each type of government are taken from a computer printout from the Department of State dated 11/03/75. 41 population categories were determined by use of the July 1, 1977, Population Estimates of Counties and Incorporated Cities of oregon, published by the Center for Population Research and Census, Portland State University, Portland, Oregon.

Actual unit estimates reflect the most recent data and estimates from agencies and labor relation practitioners in Oregon. Where this is unavailable, the most recent U. S. Bureau of Census estimates are used. 42

The Results

The aggregate data generaged from these assumptions are reflected in Table XV. This table compares the potential number of bargaining units with the actual number of units by the type of government and population. The last column 


\section{TABLE XV}

ACTUAL AND POSSIBLE BARGAINING UNITS BY TYPE OF GOVERNMENT, BY POPULATION IN OREGON

\begin{tabular}{|c|c|c|c|c|c|c|c|c|}
\hline \multirow[b]{2}{*}{ Type of Gcvernment } & \multirow[b]{2}{*}{$\begin{array}{c}\text { Number } \\
\text { in } \\
\text { Category } \\
1976 \\
\end{array}$} & \multicolumn{4}{|c|}{ Possible Individual Units } & \multirow{2}{*}{$\begin{array}{r}\text { Actual } \\
\text { Units } \\
\\
1978 \\
\end{array}$} & \multicolumn{2}{|c|}{$\begin{array}{c}\text { Estimated } \\
\text { Percent Penetration }\end{array}$} \\
\hline & & \begin{tabular}{|l|} 
Least \\
Possible \\
Individual \\
units \\
\end{tabular} & $\begin{array}{l}\text { Total } \\
\text { Least } \\
\text { Possible } \\
\end{array}$ & $\begin{array}{c}\text { Most } \\
\text { Possible } \\
\text { Individual } \\
\text { Units } \\
\end{array}$ & $\begin{array}{c}\text { Total } \\
\text { Most } \\
\text { Possible }\end{array}$ & & $\begin{array}{c}\text { Highest } \\
\text { Penetration }\end{array}$ & $\begin{array}{c}\text { Least } \\
\text { Penetration }\end{array}$ \\
\hline $\begin{array}{l}\text { State Total } \\
\text { (including higher } \\
\text { education) }\end{array}$ & 1 & 85 & 85 & 108 & 108 & 83 & 988 & 778 \\
\hline $\begin{array}{l}\text { Counties Total } \\
\text { Under. } 50,000 \\
\text { Over } 50,000 \\
\text { within SkSA } \\
\text { Multnomah }\end{array}$ & $\begin{array}{r}36 \\
23 \\
7 \\
5 \\
1\end{array}$ & $\begin{array}{l}- \\
2 \\
4 \\
5 \\
9\end{array}$ & $\begin{array}{r}108 \\
46 \\
28 \\
25 \\
9\end{array}$ & $\begin{array}{l}- \\
2 \\
5 \\
7 \\
9\end{array}$ & $\begin{array}{r}125 \\
46 \\
35 \\
35 \\
9\end{array}$ & 70 & 658 & 568 \\
\hline $\begin{array}{l}\text { City Total } \\
\text { Under } 1,500 \\
1,500=2,500 \\
2,500=10,000 \\
10,000-50,000 \\
\text { Salem }(83,170) \\
\text { Eugene }(100,450) \\
\text { Portland }(384,500)\end{array}$ & $\begin{array}{r}239 \\
127 \\
37 \\
46 \\
26 \\
1 \\
1 \\
1\end{array}$ & $\begin{array}{r}- \\
0 \\
1 \\
2 \\
4 \\
4 \\
4 \\
12\end{array}$ & $\begin{array}{r}253 \\
0 \\
37 \\
92 \\
104 \\
4 \\
4 \\
12\end{array}$ & $\begin{array}{r}\overline{0} \\
1 \\
2 \\
5 \\
6 \\
6 \\
32\end{array}$ & $\begin{array}{r}283 \\
0 \\
37 \\
92 \\
130 \\
6 \\
6 \\
12\end{array}$ & 116 & 468 & 418 \\
\hline $\begin{array}{l}\text { Education Total } \\
(P S+I E D)\end{array}$ & 369 & - & 721 & - & 734 & 700 & 978 & 958 \\
\hline $\begin{array}{l}\text { Public Schools } \\
\text { ADM under 9,000 } \\
\text { ADM over 9,000 } \\
\text { Portiand }\end{array}$ & $\begin{array}{r}340 \\
333 \\
6\end{array}$ & $\begin{array}{l}- \\
2 \\
2 \\
4\end{array}$ & $\begin{array}{r}682 \\
666 \\
12 \\
4\end{array}$ & $\begin{array}{l}- \\
2 \\
3 \\
6\end{array}$ & $\begin{array}{r}690 \\
666 \\
18 \\
6\end{array}$ & & & \\
\hline ILD In co. usicer & 29 & - & 39 & - & 44 & & & \\
\hline $\begin{array}{l}50,000 \\
\text { In co. over } \\
50,000 \\
\text { within SMSA }\end{array}$ & $\begin{array}{l}5 \\
5\end{array}$ & 2 & $\begin{array}{l}10 \\
10\end{array}$ & $\begin{array}{l}2 \\
3\end{array}$ & $\begin{array}{l}10 \\
15\end{array}$ & & & \\
\hline Community College & 13 & 2 & 26 & 2 & 26 & 26 & 1008 & 1008 \\
\hline $\begin{array}{l}\text { Higher Education } \\
\text { (Counted in State) }\end{array}$ & ) & 2 & 16 & 3 & 24 & 15 & 948 & 638 \\
\hline $\begin{array}{l}\text { Special Districts } \\
\text { Total } \\
\text { Within SMSA's } \\
\text { All Others } \\
\text { Port of Portland }\end{array}$ & $\begin{array}{r}930 \\
201 \\
728 \\
1\end{array}$ & $\begin{array}{l}\overline{1} \\
1 \\
1 \\
8\end{array}$ & $\begin{array}{r}937 \\
201 \\
728 \\
8\end{array}$ & $\begin{array}{l}- \\
2 \\
1 \\
1\end{array}$ & $\begin{array}{r}1,138 \\
402 \\
728 \\
8\end{array}$ & 93 & 108 & 88 \\
\hline $\begin{array}{l}\text { All State and Local } \\
\text { Government Total }\end{array}$ & 1,596 & & 2,141 & 2,348 & & 1,103 & & \\
\hline
\end{tabular}


shows the percentage of penetration. The table shows the minimum number of individual public employees bargaining units at the state and local level to be about 2,100, with a conservative maximum figure of about 2,400 .

The education sector has the highest percent of penetration by collective bargaining units. Specifically, pubIic schools have between 95 percent and 97 percent of the potential bargaining units already bargaining; community colleges are 100 percent penetrated, and higher education at least 62 percent penetrated, and possibly as high as 94 percent penetrated. With the exception of higher education, there is little if any room for collective bargaining growth in Oregon's education sector. This level of organization may be due to several factors, including the national power of the NEA, decline in enrollment, and the long experience with meet-and-confer laws that stimulated school districts bargaining years before the other sectors.

The state is second highest with at least 77 percent and possibly 97 percent penetration. This is due to the 1965 law that encouraged collective bargaining at the state level.

Counties have the third highest rate of collective bargaining, with a minimum of 56 percent and a maximum of 70 percent of the potential bargaining units already in existence. It is expected that when, and if, the Oregon supreme Court makes a definite ruling in favor of the constitutionality of the 1973 state law, that county penetration will 
increase very rapidly. Although data relating penetration and population is not available, it is theorized that the more populous counties (such as Multnomah, Washington and Clackamas) presently are organized to a higher degree than the less populous counties, thus future increases in organization and collective bargaining would most likely take place in counties that are not presently within a standard Metropolitan Service Area (SMSA).

Cities are between 41 percent and 46 percent penetrated. This is most likely due to the impact of the home rule issue. It is expected that once this issue is resolved, a very rapid increase in organization and bargaining units will take place at the city level. It might be further theorized that because the cities have resisted complying with the law that it is within the city sector that many future labor relations problems may exist.

Table XV shows that special districts have the least amount of penetration by bargaining units, with about 10 percent. Because many are so small, and diverse, it is expected that special districts will remain relatively the least organized, even when substantial growth is considered.

\section{Implications}

The amount of resources needed by public employers in Oregon to engage in collective bargaining, and all its aspects, is substantial (especially considering the costs of negotiation and impasse resolution). When one considers 
the changes in management techniques necessary, along with budgetary aspects, one can appreciate the concern over the effectiveness of Oregon's collective bargaining law and the vast changes it is bringing about.

of particular concern to Oregon, as with the rest of the nation, is the effectiveness of the impasse resolution procedure as a way to avoid public sector strikes. The next chapter will deal with the theoretical aspects of impasse resolution so that Oregon's impasse procedure may be placed in a theoretical or philosophical context. 
CHAPTER III NOTES

${ }^{1}$ Joseph Grodin, and Mark Hardin, "Public Employee Bargaining in Oregon," Oregon Law Review, 51 (1971), 10-11.

2or. Laws Ch. 579 (1963).

3 Melvin H. Cleveland, "Public sector Labor Relations Legislation in Oregon," Proc. of the Twelfth Labor Management Conference on Collective Bargaining and Labor Law. January 1976 (Tucson, Ariz.: Univ. of Arizona, 1976), p.1.

${ }^{4}$ or. Laws Ch. 390 (1965).

${ }^{5}$ Or. Laws Ch. 543, secs. 2-4 (1965).

${ }^{6}$ Grodin and Hardin, p. 13.

${ }^{7}$ Cleveland, p. 2. Also see Or. Laws Ch. 80 (1969).

${ }^{8}$ Grodin and Hardin, p. 14.

${ }^{9}$ Grodin and Hardin, p. 52-54. According to Melvin $\mathrm{H}$. Cleveland, ERB Chairperson, there were about 40 units bargaining that included Douglas Co., the cities of Roseburg, Eugene and Portland, Salem School District, and the Port of Portland.

10 The Governor's task force consisted of the present State Attorney General James Redden, who was then a Medford attorney with labor law experience, Mr. Leroy Smith a retired federal mediator, and Dr. Paul Kliensorge, Director of the Industrial Relations Center at the University of Oregon.

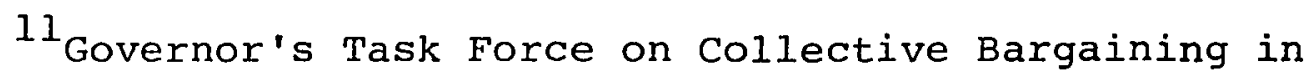
the Public Sector, Testimony to the House committee on Labor and Industrial Relations, 31 May 1973, p. 2 . 
12 Governor's Task Force on Collective Bargaining in the Public Sector, Testimony to the Senate Committee on Iabor and Industrial Relations, 31 May 1973, p. 2 .

13 Personal interview with James Redden, 13 June 1978. Telephone interview with Dr. Paul Kleinsorge, 19 June 1978. Personal interview with Leroy Smith, 25 July 1978.

${ }^{14}$ Telephone interview with Melvin H. Cleveland, Chairperson, Employment Relations Board, 26 February 1979.

${ }^{15}$ Oregon Revised Statutes, sec. 243.656 (1-5) (1977).

${ }^{16}$ Oregon Revised Statutes, sec. 240.060 (1977).

17 Oregon Revised Statutes, secs. 243.682 and 243.686 (1977).

${ }^{18}$ ORS 243.682 and 243.686.

${ }^{19}$ Oregon Revised Statutes, sec. 243.692 (1977).

20 Oregon Revised Statutes, sec. 243.676 (1977). Defined in Oregon Revised Statutes, sec. 243.672 (1977).

${ }^{21}$ Oregon Revised Statutes, sec. 243.696 (1977).

22 For detailed information on ERB scope of bargaining decisions see Oregon State Employment Relations Board Case Nos. C-278, C-279, C-280, and C-344.

23 Oregon Revised statutes, sec. 243.706 (1977).

24 oregon Revised Statutes, sec. 243.650 (10), and oregon Revised Statutes, sec. 243.666 (1) respectively.

25 oregon Revised Statutes, secs. $243.712, .722, .726$, and .742 .

${ }^{26}$ oRs $243.726(2 c-d)$.

27 ORS 243.726 ( $3 a$ and $c)$.

${ }^{28}$ ORS $243.726(2,4$, and 5$)$. 
${ }^{29}$ ore. Const. Art. IX, sec. 2 .

${ }^{30}$ Ore. Const. Art. VI, sec. 10. The home rule counties are Lane, Washington, Hood River, Multnomah, and Benton.

${ }^{31}$ Grodin and Hardin, p. 33 .

${ }^{32}$ Cleveland, p. 7.

${ }^{33}$ Telephone interview with Roy Edwards, senior hearings officer ERB, 9 October 1978.

34 Oregon Supreme Court Reports, Advance Sheets, 78, No. 4 (Feb. 21, 1978), p. 156.

${ }^{35}$ Interview with Cleveland.

${ }^{36}$ Interview with Edwards.

37 Interview with cleveland.

38 Oregon Legislative Assembly, Report of the Joint Interim Committee on Labor and Commerce, 59 th Oregon Legislative Assembly, December 1976, p. 9.

39 These numbers are rounded as Table XI includes employees not covered by the law (e.g. part-time, temporary, CETA and seasonal employees).

${ }^{40}$ Estimates provided by John Abernathy, arbitrator, and John Vale of the State Conciliation Service. Also see U. S. Bureau of the Census, Labor Management Relations: 1976.

$4 I_{\text {This }}$ computer printout was provided by the office of the Secretary of State, State of Oregon, dated 3 Nov. 1976.

${ }^{42}$ See note 40 and 41 above. 
CHAPTER IV

THE GENERAL NATURE AND THEORETICAL BASIS OF IMPASSE RESOLUTION IN THE PUBLIC SECTOR

This chapter will investigate the purpose, theory, and nature of impasse resolution. The three basic types of impasse resolution -- mediation, fact-finding, and interest arbitration -- will be covered, along with a brief discussion on various combinations and hybrid forms of the three. However, the emphasis will be placed on fact-finding -- the central topic of this dissertation.

\section{The Purpose}

Impasse is defined as: "A situation in collective bargaining which occurs when the employer and the union, both negotiating in good faith, fail to reach agreement." 1 In the private sector such disputes, or impasses, have traditicnally been resolved through use of mediation services or by the exercise of economic power in the market place, with the unions' ultimate weapon being the strike and the employers' the lockout.

Because of its negative impact on the public interest, use of the strike has almost universally been deemed inappropriate in the public sector. The challenge has then been to develop procedures that will facilitate reaching a settlement of an impasse, within the framework of voluntary 
collective bargaining between public employers and employees. ${ }^{2}$ Impasse resolution procedures, then, are designed to encourage the resumption of good faith bargaining and progressively introduce a higher level of intervention by some neutral third party. ${ }^{3}$ Legislators considering impasse resolution are advised by Roy Wesley not to "make impasse resolution machinery too attractive, available and unrisky or the parties will give up on the hard work of bargaining and turn their dispute to others." 4 His statement reflects our nation's commitment to free collective bargaining as a vehicle operating within a framework of law for the parties to resolve their problems voluntarily, rather than to submit to government imposed settlements.

In short, impasse resolution procedures have been developed as political substitutes for the strike, with the intention of protecting government functions from serious disruption and at the same time granting public employees similar labor rights guaranteed private sector employees under the Taft-Hartley Act.

Before discussing the modes of impasse resolution, it must be emphasized that even under the best of conditions impasse procedures will not always work and that the public must accept the fact that some public sector strikes will occur. Recent United States experience has shown that outlawing public sector strikes has not prevented them. This suggests that the strike should be illowed as a tool of last resort after all alternatives have been fully explored. 5 
The three basic forms of public sector impasse resolution are mediation, fact-finding, and interest arbitration. These terms are defined below:

Mediation, often referred to as conciliation, "mean[s] the use of a neutral third party(s) as intermediary to assist in the resolution of a dispute without the authority to impose a settlement." 6

Fact-finding, "involves the appointment of a respected, neutral third party who is chosen to study the facts underlying a dispute and to issue a report with specific recommendations for a fair settlement." 7

Interest arbitration occurs when a neutral third party adjudicates over the terms and conditions of employment and where the decision is binding on both the contending parties. 8

These strike substitutes, or alternatives, take a variety of forms which reflect the level of government, state laws, and the controversy over which form and/or combination of forms is the most viable method of impasse resolution. ${ }^{9}$

\section{IMPASSE RESOLUTION LAW}

Federal Sector impasse resolution procedures, which cover employees of the Executive Branch (excluding postal employees), are set forth in section 16 and 17 of E.O. 11491. 10 Section 16 charges the Federal Mediation Service (FMCS) to "provide services and assistance.. . in the resolution of negotiation disputes . . and under what circumstances and in what manner it shall offer services." These services include preventive mediation (assistance by a neutral third party prior to impasse) and mediation. 
Section 17 provides further procedures if mediation fails. In this case the Federal Service Impasse Panel (FSIP), may at the request of either party or on its own initiative, consider the matter, and may determine that fact-finding or arbitration is necessary as a final step. Federal employees are prohibited from striking by section 19 of the same act. In the case of fact-finding, the FSIP makes recommendations based upon the fact-finders' report; and if the parties do not accept their recommendations or settle within thirty days, the FSIP can require binding arbitration. II

Because the parties do not know in advance exactly what mechanism the FSIP will recommend, the parties are encouraged to continue to bargain rather than to rely on a third party to resolve their dispute. 12

The Postal Reorganization Act of 1970 allows postal employee unions and the federal government to adopt their own procedures for impasse resolution; however, if such procedures are not established or are ineffective, the FMCS will establish a tripartite fact-finding panel that reports findings with or without recommendations. If no agreement is reached after fact-finding and the parties have not decided upon arbitration, a tripartite arbitration board will render a binding decision. 13

Anthony V. Sinicropi and Thomas P. Gilroy summarize federal level impasse resolution by stating that: - . E. O. 11491 and the Postal Reorganization Act, stress the use of voluntary arrangements by the parties supported by the use of mediation, fact- 
finding and arbitration where voluntary arrangements fail. The postal procedures rely heavily upon the "outside neutral" while the Executive Order includes the use of a permanent impasse structure through the use of the FSIP and the FLRC. 14

State legislation dealing with impasse resolution, as mentioned before, reflects a wide diversity of institutional arrangements. A Department of Labor Publication reported in 1972 that:

- . at least thirty-four states had enacted legislation with interest dispute procedures in public employment... . [They] range in employee coverage from one specific occupational group, such as teachers to statutes with comprehensive coverage . . . At least twenty-five states provided in some way for mediation of negotiation disputes . . . The provisions for mediation differ among and within states with respect to how the procedure is initiated, who provides the service, the use of one mediator or a panel, the relationship of mediation to other impasse procedures, and provisions for payment of costs . . . At least twenty-three states authorize the use of fact-finding. . . . As with mediation, there is considerable variation in the relationship of fact-finding to other procedures within states . . . Twentythree states had legislation authorizing voluntary or compulsory arbitration for the resolution. of some or all outstanding issues in certain public sector disputes . . . Eleven states. - provided for compulsory arbitration of certain interest disputes. 15

Appendix D summarizes the type of state interest dispute procedures provided by various state laws.

The diversity of state impasse procedures is reflected in the differences between the: three west Coast states. Oregon law provides a uniform impasse procedure that requires mediation, fact-finding, and a cooling-off period; these are followed by compulsory interest arbitration for 
the protective services and strike for all other public employees. 16

The state of Washington has an extremely fragmented legal framework for public sector collective bargaining. The impasse procedures vary greatly among the eight laws that cover different categories of public employees. The Washington state Public Employment Relations Commission (PERC) does not administer all of the laws.17 For example, non-uniformed personnel in cities, counties, and special districts are required to use PERC mediation, while uniformed personnel (police and fire) are required to use mediation, and may invoke a fact-finding panel, and may invoke interest arbitration. The right to strike is not granted. 18 state community colleges may use PERC mediation and fact-finding services upon consent of both parties. There is no reference to a strike policy. 19 In the Washington state Ferries system either party may invoke PERK final and binding arbitration, ${ }^{20}$ while there is no reference to impasse procedure covering state civil service employees. $^{21}$ In short, in the state of Washington collective barçaining laws and impasse procedures differ according to governmental levels and function.

California, like Washington, does not grant the right to strike to public employees, and the impasse procedure varies with the type of government. 22 For example, parties involved in municipal disputes may appoint a mutually agreeable mediator, ${ }^{23}$ while teachers are required to use the 
state mediation and fact-finding services. 24 In California disputes involving state employees are covered by a Governor's Executive order. The governor's representatives issue a written report on differences between the parties and this report is made public. 25

This brief overview of the Oregon, Washington, and California approaches to impasse resolution serves to demonstrate that states are experimenting with wide varieties of types and combinations of impasse resolution. These experiments are based upon particular characteristics that each type is purported to possess.

\section{CHARACTERISTICS OF IMPASSE RESOLUTION}

\section{Mediation}

Mediation, which is also used extensively in the private sector, is the most non-controversial and acceptable form of impasse resolution procedure because it is compatible with voluntarism. It is at the mediation stage of impasse resolution that most disputes are resolved. ${ }^{26}$ The mediator serves as a go-between who "has no power of compulsion but only of persuasion" and therefore aids parties in reaching their own compromises through the collective bargairing process. 27

In order to fulfill this role, the mediator meets with both sides, jointly or separately, in order to assess the issues, explore possible compromise, and advise the parties on how to sell proposals to their constituents. Roy Wesley 
states that "He [The mediator] is not concerned with fairness or justice of the solution. His objective is to reach one, period." 28

In order to accomplish this goal, a mediator must have the confidence of the parties. Their confidence is based upon a mediator's ability to assume a posture of complete neutrality. Robert G. Howlett, when discussing the role of the mediator, concluded:

A mediator did not force anyone to do anything. He shared, but never betrayed confidences. Like a closed-mouth mistress, he eased frustrations; and like the experienced lady of the brothel, did not need the passion of an advocate. 29

Mediation, however, is not always successful for two reasons. The first involves the shortage of competent mediators, the second the parties' attitudes.

Arnold Zack attributes the shortage of competent mediators to the lack of familiarity of public sector problems by private sector mediators. The shortage is aggrevated by the cyclical pattern of public sector bargaining, which results in many negotiations reaching impasse in the same state at the: same time. 30 such shortages of competent mediators may leave the parties in a position where a mediator is not available, or worse yet, where the mediator causes more problems than he helps solve.

The second problem is summarized by William B. Gould, who states that "mediation cannot achieve anything if the parties refuse to budge from their respective positions. The best of mediators cannot unsnarl recalcitrant parties 
and untractable issues." 31

There are several alleged reasons for such extreme positions. First, the uniqueness of the public sector gives both employer and employee more staying power than in the private sector. Second, because collective bargaining is relatively new to the public sector, both parties may be inexperienced and naive about the process; and in the employers' case, even hostile toward collective regotiations with the employees over whom the public employer previously has had unilateral control. ${ }^{32}$ Third, both parties may be encouraged to hold back settlement in hopes that factfinding or arbitration will bring a more favorable settlement. 33

When the mediator is unable to persuade the parties to reach a settlement, he may recommend or invoke fact-finding or another procedure (depending on the local or state law).

Fact-Finding

Like mediation, fact-finding, is an extension of the consultation process since it keeps open the possibility for voluntary settlement between the parties. However, the process goes beyond mediation and involves formal recommendations. The recommendations are not binding on the parties, but are designed to serve as the basis for further consultation and agreement. 34

The process of fact-finding has received much attention and has been the recipient of much controversy, in part because there has not been extensive experience with it in the private sector, and because only recently has it had heavy usie and evaluation in the public sector. 35 Although 
this heavy use is recent, fact-finding did not originate with the public sector in the 1960's. Jacob Finkelman states that "fact-finding became part of the labor-management process in Canada as long ago as 1907." 36 In the U. S., present fact-finding procedures are derived from the Emergency Board procedures that cover the private sector under the Railway Labor Acts of 1926 and Taft-Hartley Act of 1947. 37 Presently some thirty states require fact-finding in one form or ancther. 38

The theory behind the fact-finding process is that of the issuance of findings and recommendations along with public pressure will force the parties to drop extreme positions and to settle voluntarily. George Hilderbrand views fact-finding as a very effective mechanism because the hearing provides a public forum to discuss the issues and air differences, and the recommendations serve as a guide to the parties and as an information source to the public, who may influence governmental leaders toward rational decision making. 39

However, fact-finding may occur under several different circumstances that yeild different results. One circumstance is fact-finding without recommendation, another circumstance is fact-finding with recommendations. Each may occur before or after an impasse. ${ }^{40}$ These different circumstances relegate the fact-finding process to the nebulous category of "neither fish nor fowl." On the one hand, fact-finding may more resemble mediation if the hearings 
are informal, the fact-finder engages in mediation as well as finding facts, and esfecially if no recommendations are issued. 41 on the other hand, it may more resemble arbitration if the hearings are formal or quasi-judicial, mediation is absent, and recommendations are issued. ${ }^{42}$ William $B$. Gould states that "the fact-finding process necessarily partakes of both the mediatory and judicial disciplines . . . The process is a fluid one abcut which drawing of hard and fast lines is still an audacious act." 43

Because of this fluidity, there is much controversy about what fact-finding is and ought to be, and what it does and does not accomplish. The issues involved in this controversy will now be discussed.

\section{Structural and Process Issues in Fact-Finding}

Recommendations or Facts. This issue refers to the concept that the word "fact-finder," in its purest sense, would limit the fact-finders' role to finding and publishing the facts. The reasoning is that once the fact-finder makes recommendations, his role shifts from that of a finder-offacts to one of interpreting facts and exercising value judgements. ${ }^{44}$ Because of this shift in role, it has been suggested that fact-finding involving recommendations be called "advisory" arbitration (because judgement is involved and recommendations are not binding).

Be that as it may, it is generally accepted that factfinding without recommendations (in an impasse situation) in 
both the private and public sectors is not likely to be very successful. This is because the establishment of facts does not necessarily provide a basis for compromise between the parties, and the: publication of facts may not be of much interest to the public, given the complexity of most labor disputes. 45

Fact-Finding Without Recommendations. There are, however, circumstances where fact-finding without recommendations may prove to be very useful. One circumstance would be in a situation where a neutral party would be appointed well in advance of negotiations to develop factual background for use by the bargainers. Fact-finding in this case is seen as potentially very useful because as the scope of bargaining expands and the issues become more complicated and technical, competent experts are needed in whom both the parties have confidence. 46

Another such circumstance would be fact-finding without recommendation on issues, but with procedural directions. This would be useful to aid parties, in light of the facts, in getting back on the road to negotiations by revising the structure of bargaining. 47

In cases that involve impasse, however, Robert G. Howlett reflects the general feeling in his now often quoted statement that "fact-finding without recommendations is about as useful as a martini without gin." 48

Fact-Finding with Recommendations. The rationale behind fact-finding with recommendations involves three principles. 
First, the impact of public opinion, whet ther real or potential, is more likely to be brought to bear upon the parties after a respected neutral makes recommendations for a "fair" settlement. Because neither party desires public hostility, rejection of such a report may invite criticism from newspapers and other sources; thus the parties feel a push behind the fact-finder's recommendations. 49 whether this is realistic will be discussed later.

Second, the fact-finders' recommendations allow parties who have taken extreme positions to back down without losing face. In this case the fact-finder collects his fees, leaves his report, and becomes (in the words of practitioners) a "scape goat" or "per deim fall guy." This role occurs when the negotiators explain to their constituents that the factfinder recommended something other than their bargaining position; the parties, then, may appeal to their constituents (the public and union members) that it would appear to be unreasonable if the fact-finders' report is rejected; and thus both sides are able to compromise without losing face. 50 Third, the fact-finders' recommendations can be equitable and innovative enough to gain support by both parties, thus ending the impasse without the use of the strike. ${ }^{51}$ From this stem two other major issues involving the factfinders' actions and the type of recommendations the factfinder makes.

Adjudication or Mediation. This issue may be simply expressed by the question: "Ought the fact-finder to engage 
in mediation during the fact-finding process?"

Robert Howlett is convinced that if there has been effective mediation, the role of the fact-finder should be primarily judicial because mediation efforts by fact-finders have the following negative impacts:

(1) It destroys the confidential nature of mediation; (2) some qualified fact-finders (arbitrators), who have no collective bargaining experience, are not skilled in mediation; and (3) our mediators felt, quite properly, that mediation by an ad hoc mediator after a staff mediator had completed his work carried an implication that the staff mediator had not performed his job... .

The debate over whether to combine mediation and fact-finding appears to arise principally from those jurisdictions that do not have an established, competent mediation staff ... 52

Harold P. Seamon alsc supports the view that fact-

finders should generally not engage in mediation. However, he would allow the fact-finder to encourage the parties to resume negotiations (and even recess the hearing for that purpose) if the fact-finder senses that the parties may be able to settle certain issues by themselves. 53

There are, however, some who think fact-finders should and, indeed, have to mediate. William Simkin states "Where fact-finding has been successful, I would suggest, but cannot prove, that the fact-finder has mediated -- deliberately, instinctively, or surreptitiously." 54 James $C$. Hill in reference to contract disputes, supports Simkin by saying:

- . [fact-finding] is essentially an extension of the mediatory process, in which the fact-finder seeks to fashion a recommendation which is acceptable to the parties, or at least within the area
of their expectations. 55 . 
In discussing the Michigan experience with fact-finding, Bejamin W. Wolkinson and Jack Stieber report the parties were generally opposed to fact-finder mediation and concluds that unless the parties request mediation or mutually agree that further mediation would be useful, fact-finders should avoid mediation. 56

In the process of attempting to conclude this debate, Robert $J$. Jossen found that most states' statutory language did not provide a clear indication as to the nature of factfinding, and that just because most fact-finding reports are written in the form of an adjudication procedure, one should not assume that mediation was not involved. Jossen also found that the role of the fact-finder varies depending upon a number of variables, including the fact-finder's background, bias, and perception of what his role ought to be. 57 Jean T. Mckelvey, concurring with this view, further suggests that "It [fact-finding] may often be a mixture of both [adjudication and mediation] with a large infusion of political and strategic considerations." 58

It is apparent that this disagreement among experts as to whether fact-finding ought to be adjudication, mediation, or both, depends upon the states' law, socio-economic structure, quality of mediation service, and the fact-finders' own philosophies. However, few would take the position that mediation is always inappropriate. Therefore, the general view is within a range of degree with respect to the encouragement of mediation occurring during fact-finding. 
Recommendations: Just or Acceptable. This issue refers to the nature of the fact-finders' recommendations. Some argue that the recommendations should stress justice; that is, reflect what is fair and equitable rather than what is acceptable. 59

James C. Hill questions the three basic assumptions behind the theory of judicial fact-finding. First, he is unsure whether public pressure is significant once the facts are known; second, he questions whether there are standard criteria that can be used to determine wages and other conditions of employment; and third, in new contract conditions, a fact-finder (like an arbitrator), for pragmatic reasons, must seek a solution which is acceptable. 60

Arnold Zack avoids the argument by equating acceptability and public interest, and by placing community responsibility on the parties, not the fact-finder. He sums up his view when he states "If both agree to a settlement, it must be concluded that community responsibility has been met." 61

Because the fact-finders' role is to bring the parties together voluntarily in order to avoid strike, others put great emphasis on the fact-finders' report reflecting acceptability. Donald $\mathrm{H}$. Wollett bluntly states that "The fact-finders are not expected to dispense justice; they are expected to arrange peace." 62

Practically speaking, a fact-finder in this position must consider the relative bargaining power of each party and make recommendations accordingly. Because of this, 
some experts, such as Robert E. Doherty, fear that "a fair settlement has come to mean that sort of bargain one has the power to secure," 63 rather than one reflecting a standard o: fairness and the public interest.

The moderate view, as expressed by Harold Seamon, recognizes a need for balance between what is just and acceptable. ${ }^{64}$ This view is supported and summarized by Tim Bornstein when he says "This is not to say that the factfinder should make recommendations based solely on what he senses the parties will take, but it is to say that he must be conscious of his role." 65

It becomes apparent that the acceptability vs. justice issue also reflects a wide range of opinion; and perhaps one might conclude, as Gould did in a previous quote, that it would be audacious to draw hard and fast lines. There is, however, an issue that is not surrounded by as much vagueness, and which is at the core of the usefulness of factfinding. That issue is the impact which fact-finding has on negotiation and mediation.

\section{Undermining Negotiations and Mediation. This issue} refers to the possibility that the parties may assume and maintain extreme positions during negotiations and mediation in anticipation that the fact-finders' recommendations will bring them to a compromise near their perceived last offer. The results of such action is an erosion of the collective bargaining process and an undermining of mediation efforts. 
William Simkin likens fact-finding to a "one-play ball game," where "with adequate tenacity and ability, some play will succeed." 66 Jean McKelvey's concern, in reference to the Railway Labor Act, is that "fact-finding may become an addictive habit, [that is], the first and not the final step in collective negotiations." 67 Arnold zack concurs with this concern when he states "Fact-finding has, in fact, come to be accepted as yet another appeal beyond mediation." 68

However, others claim it may not harm negotiations or mediation because parties are aware fact-finding can yield inexact and urpredictable recommendations, and that they are therefore encouraged to settle themselves. ${ }^{69}$ It is known that some mediators use this argument as a threat to parties in order to pressure a settlement in mediation. Krinsky found in a wisconsin study that intital use of factfinding improved the bargaining relationship by contributing to the education of the parties. This is because the report provided them with a neutral perspective of what was a reasonable solution, and the experience made them understand that they should be able to reach the same point as the fact-finders' recommendation through negotiations, thus avoiding the time and monetary costs involved in the factfinding process. ${ }^{70}$

Other studies show conflicting conclusions. For example, Wolkinson and Stieber concluded in their Michigan study that "Evidence suggests that the bargaining posture 
[hold-back] is not widely maintained,"71 while Yaffe and Goldblatt reported in their New York study that "Parties 'wait' for fact-finding and 'hold-back.'"72 Tim Bornstein supports this view and further suggests that unions are perhaps more prone to rely too heavily on fact-finding than employers; he states "because unions normally cannot strike, they sometimes reason that they have everything to gain and nothing to lose by going to fact-finding." 73

In an effort to encourage negotiations and make mediation more attractive, Arnold Zack proposes several suggestions that are intended to make fact-finding less accessible and more final. These suggestions are: (1) that parties pay for the cost of fact-finding, (2) that factfinders not have access to mediation information in order to make their findings less predictable and not to undermine the confidentiality of the mediator, (3) that unfair labor practice penalties be imposed on those who do not negotiate in good faith, and (4) that the fact-finder assume an adjudicatory role so parties cannot expect a "split of the differences." Zack further emphasizes that improvement of the fact-finding step, rather than extensions of the process such as super-mediation, is desirable in order to make fact-finding the final step in the process and short of a legal or illegal strike. ${ }^{74}$ However, even with these reforms, there are questions as to whether fact-finding can work well, given the lack of public pressure. 


\section{Public Pressure. This issue reflects concern over}

whether the publication of fact-finding recommendations does in fact marshall public opinion to the extent that the par. ties feel pressured into accepting the fact-finders' report. William Word reports that in the case of New York and Wisconsin, public opinion did not seem to be very influential, 75 and Donald $w$. Wollett bluntly says that it is "a romantic delusion" to think the public will comprehend and respond constructively to a fact-finders' recommendation. 76 The lack of public interest and pressure may be due in part to the fact that the reports are not readily available, nor, at times, understandable to the general public. ${ }^{77}$ Allan $\mathrm{W}$. Drachman further suggests that even if the public is interested, "public opinion has very little impact if either the municipal employer or the union is in a weak bargaining position relative to the opposing party." 78

Other Issues. Several other issues arise with respect to fact-finding. Time is another doubled edged sword. On the one side, if too much time lapses between the request for the hearing and when it actually takes place, the union may become more prone to strike, or the budget submission date may pass, causing further inflexibility. 79 on the other side, this time-lapse gives both parties the opportunity to reassess their positions and to let their emotions calm. Even the question of whether fact-finding should be conducted by a tripartite panel or a single individual stirs debate. Jerry Wurf states thât a tripartite panel consisting 
of one labor, one management, and one public representative, "provides for true neutrality." 80 on the other hand, it may encourage a mediation approach rather than adjudication approach, which might be less likely where there is only one neutra1.

The effectiveness of fact-finding is also questioned even though there are studies which, utilizing systematic investigation, indicate the effectiveness of fact-finding. For example, Yaffe and Goldblat concluded that although imperfect as a strike substitute, fact-finding in New York State offered "more promise than illusion as a mechanism to facilitate the resolution of interest disputes in public sector negotiations." 81 In their Michigan study Wolkinson and stieber stated that the process is a "viable mechanism for dispute resolution that should be continued and strengthened. " 82

However, this evidence has not quelled the controversy because of its impact on negotiation strategy and mediation efforts. Krinsky, in his Wisconsin study, does concur that fact-finding was very effective in settling disputes and avoiding strikes, but he seriously questions its ability to accomplish "just" gains from the employee's standpoint. 83 Again there exists a diversity of opinion as to the effectiveness of fact-finding, just as there is on most issues surrounding fact-finding.

One reason for this diversity of opinion is the difficulity in comparing fact-finding among states because of 
differences in state laws, impasse procedures, socioeconomic structures, and administrative philosophies. Another reason is the shortage of systematic investigation and analysis of the process. Thus, more research and experience is needed before most experts would be willing to fully endorse the fact-finding process.

In fact, there are other alternatives that are thought to be a superior last step in public employee impasse resolution. One of these, of course, is the strike, (which only a few states allow), the other processes are various forms of interest arbitration.

Interest Arbitration

Interest arbitration has become quite widespread as the last step in impasse resolution. Although it may take two forms, voluntary and compulsory, it is the compulsory form that is utilized most often in the public sector. This is especially true for the essential services, such as police and fire, where the public health and safety is paramount. Arbitration usually occurs after efforts at mediation and perhaps fact-finding have been exhausted. Unlike factfinding, arbitration is clearly a process of adjudication, not compromise. 84 In the case of compulsory binding arbitration, the parties, after exhausting other impasse procedures, are required by law to submit their case to a neutral for a binding decision. 
Frank and Edna Elkouri cite three basic arguments in favor of compulsory arbitration. First, it protects citizens from a strike which may endanger the health and safety of the general public. Second, it substitutes judicial procedures that consider the merits of a case in place of the "jungle warfare" of power politics and the strike. Third, at times it is necessary to balance power between employer and employee where strike is prohibited. ${ }^{85}$

The arguments against compulsory arbitration are fourfold. First, it undermines good-faith bargaining because a weaker party may have little to gain from bargaining; furthermore, as Merton Berstein suggests, "since arbitrators may treat the best disclosed offers as the permissible limits of the award, it pays for each side not to disclose how far it is really willing to go on each issue." 86 However, a counter argument is that some parties are finding that the arbitrator's decision may not result in as positive results as collective bargaining, and the possibility exists that on non-economic issues, the arbitrator may present a solution that is administratively unpalatable; thus the parties are encouraged to bargain in good faith. It is Howlett's opinion that the U. S. experience (although not extensive) does not reflect the pessimistic view about arbitration weakening negotiations. ${ }^{87}$

Second, compulsory arbitration may involve an unconstitutional delegation of legislated power, as wage decisions and resource allocations involve public policy. Put more 
simply: "elected officials should not delegate the duty they owe the electorate to settle these questions." 88 This view centers on the sovereignty of the state argument that has been discussed in detail in the chapter regarding collective bargaining in the public sector.

Third, it is argued that arbitration decisions may have enforcement problems, thus "divulging the impotence of government." 89 Because most arbitration decisions are acceptable, this is not generally a problem; but "illegal strikes have been known to occur in the event of unfavorabj.e arbitration awards." 90

Fourth, some are concerned that it may lead to an economy with administered prices which would threaten the voluntary collective bargaining process, the free market, and enterprise system as we know it. ${ }^{91}$ This argument is akin to that in economics where the use of wage and price controls involve a trade off between "economic freedom" and macro-economic stability. In that case the pill is bitter, but the disease worse.

Problems such as these lead Wellington and winter to conclude that "compulsory and binding arbitration is no panacea either."92 George W. Taylor states "Neither compulsory arbitration nor strikes are appropriate in public employment relations" and stresses that we need to develop new procedures to deal with the dilemma. 93 Many are in agreement with Taylor, and innovative suggestions have resulted. 
Innovations in Arbitration

Final-offer arbitration such as instituted in Michigan and Eugene, Oregon, is one such innovation. In this case, the last best offer of each party is submitted to an arbitrator who chooses one or the other. The thought is that the parties will be encouraged to bargain in good faith; and in the event of impasse, if they do not move closer together, the neutral's decision may go against the less reasonalbe of the two. ${ }^{94}$ Charles $M$. Rehmus reports that in Michigan, final-offer arbitration for protective services is actually an extention of mediation, because the law does not require parties to submit their final offer until the conlcusion of the hearing. However, he does not belittle the process, because mediation during arbitration

- - is a constructive alternative to the strike or conventional arbitration... . it helps the public interest by promoting the peaceful settlement of impasse in crucial negotiations in the pubIic sector by the parties themselves. 95

But this much flexibility may cause other problems. Paul Sommers, in analyzing the Massachusetts system, states that their form of final offer is too flexible, as it includes fact-finding and allows parties to change positions before conclusions of the final offer hearing; thus, the parties have a tendency to "hold back" until the bitter end, which undermines the negotiations process. He further states that arbitration hearings have turned into a show cause hearing for not accepting the fact-finders' recommendations. In order to make final offer more effective he 
advocates dropping the fact-finding step, having only one neutral, and prohibiting the arbitrator from mediating during the hearing. ${ }^{96}$

Peter Fenille in another recent study compares wisconsin, Michigan, Massachusetts, and Eugene, Oregon, data. He concludes that with final offer: (1) parties increase their use of them as they gain familiarity (as in other impasse procedures), (2) parties use the hearings as forums for continued negotiations, and (3) mediatory efforts by arbitrators resolve many cases. To further encourage good faith bargaining he suggests another form of final-offer arbitration. This has often been referred to as mediationarbitration (med-arb). 97

Med-arb is a situation in which the neutral has a dual role. He is more than a "go between" because he has in reserve the authority of an arbitrator. Sam and John Kagel explain:

He, in effect becomes a party to the negotiations in the sense that, while negotiating, each of the contending parties must necessarily seek to convince him that their position is reasonable and acceptable... . Each party must face up to the merits of the particular issue under disucssion, because if either or both do not, the med-arbiter will make the decision. The incentive is for both parties to settle through negotiations father than have the med-arbiter make the decision. 98

Med-arb is being considered seriously because it places emphasis on negotiations, utilizes proven mediation techniques, and avoids the unpopularity of compulsory arbitration or the economic disruption and illegality of strike. 


\section{Other Innovative Proposals}

Another proposed alternative to the strike is the combination of a "nonstoppage strike" and a "graduated strike." Briefly, in the case of the nonstoppage strike, workers would continue to work full-time but forego a portion of their take home pay, which the employer matches (say 10 percent) and which is put into a fund (to be used later for publicly desirable projects). Periodically, the union may choose to increase the percent involved, or the employer may decide to switch to a graduated strike. This is theorized to have the following benefits: (1) it would attract attention without a ruinous strike, (2) it imposes less hardship on workers since their fringe benefits would not be hampered as in a strike, and also there would be no loss of jobs for an illegal strike, and (3) both parties would be under "strike" pressure but not to their complete detriment. 99

If the non-stoppage strike is not sufficient to induce settlement, a graduated strike could. Graduated strike is work stoppage in which services are successively reduced in stages, thereby steadily increasing pressure to force settlement. In Bernstein's opinion, both the non-stoppage and graduated strike would work best in tandum. 100

Another proposal, made by Sam Zagoria, is the public referendum. In this case if either party rejects the factfinders' recommendation, the issue is put on the next election ballot. This would provide a terminal point 
without strike; however, it may delay new terms and conditions, and it requires educational campaigns and thus expense to both parties. 101 Given the recent "tax revolt," one can almost predict the outcome of such an election, in spite of the needs of public employees.

Summary

Presently in the United States there is a search for impasse resolution procedures that fulfill the two goals of (1) preventing strikes in the public sector (legal or illegal) and (2) encouraging good-faith bargaining within the the voluntary collective bargaining process as we know it in this country.

The impasse resolution procedures most often used are various combinations and forms of mediation, fact-finding, and interest arbitration. Exactly which procedure and which combination is most effective is a matter of considerable debate. In order to improve impasse resolution processes, various studies in various states have been, and are being, generated to analyze these various procedures and their effectiveness. This dissertation's particular contribution to the research lies in analysis of the fact-finding phase of Oregon's impasse resolution process. To accomplish this, the major controversial issues surrounding the fact-finding process which were discussed in this chapter will be considered. The issues are: recommendations or facts, adjudication or mediation, undermining negotiations and mediation, 
public pressure, time, and effectiveness. The next chapter deals with oregon's impasse procedure and an analysis of it. 
${ }^{1}$ Alan W. Drachman, Municipal Negotiations: From Differences to Agreement, Strengthening Local Government Through Better Labor Relations. Report No. 5 (Washington, D.C.: Labor Management Relations Service. 1970) . p. 44 .

2 Harold Palmer Seamon, Jr., "Fact-Finding in the Public Sector: A Proposal to strengthen the Fact-Finders' Role," Journal of Collective Negotiations in the Public Sector, 3 $(1974), 122$.

${ }^{3}$ William E. Simkin, Mediation and the Dynamics of Collective Bargaining (Washington, D.C.: Bureau of National Affairs), pp. 25-26.

${ }^{4}$ Roy Wesley, Impasse Resolution: An Analysis of old and New Ways to End Deadlocks (Washington, D.C.: Labor Management Relations Service, 1976), p. 4 .

${ }^{5}$ Damon W. Harrison, Jr., "The Strike and Its Alternatives: The Public Employment Experience," Kentucky Law Journal, 65 (1976), 467.

6 Thomas. P. Gilroy, and Anthony V. Sincropi, "Impasse Resolution in Public Employment: A Current Assessment," Industrial and Labor Relations Review, 25, No. 4 (1972), 496 .

7 Tim Bornstein, Facts About Fact-Finding, Strengthening Local Government Through Better Labor Relations. Report No. 8 (Washington, D.C.: Labor Management Relations Service, 1971), p. 3 .

$$
{ }^{8} \text { Wesley, p. } 3 \text {. }
$$

${ }^{9}$ Thomas P. Gilroy, and Anthony V. Sincropi, Dispute Settlement in the Public Sector: The State-of-the Art (Washington, D.C.: GPO, 1972), pp. 26-28.

${ }^{10}$ Executive order 11491, "Labor Management Relations in the Public Sector," Government Employee Relations Report (Washington, D.C.: Bureau of National Affairs, 1969). 


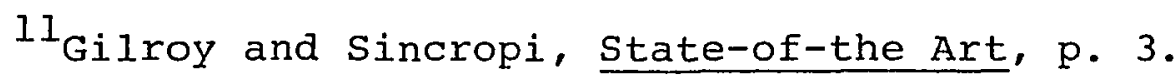

12 Eugene C. Hagburg, and Marvin J. Levine, Labor Relations (St. Paul: West, 1978), p. 186 .

13 Postal Reorganization Act of 1970, Public Law No. 91-375, 84 Statute 719, Sec. 228 (b) and (c).

${ }^{14}$ Gilroy and Sincropi, State-of-the Art, p. 5.

${ }^{15}$ Gilroy and Sincropi, State-of-the Art, pp. 8-13.

16 Oregon Revised Statutes, secs. 243.712, .722, and $.726(1977)$.

17 Letter received from Marvin Schurke, Executive Director, Washington Public Employment Relations Commission, 6 October, 1978.

18 Wash. Rev. Code. Ann., Ch 41.56 .100 (1967).

${ }^{19}$ Wash. Rev. Code. Ann., Ch 28B.52 (1971).

${ }^{20}$ Wash. Rev. Code. Ann., Ch 47.64 (1949).

${ }^{21}$ Wash. Rev. Code. Ann., Ch 41.06 (1967).

22 Despite the illegalj.ty of strike, there were 822,000 public employee work days lost due to strike between 1973 and 1976 in California. See James Gallagher, Impasse Resolution in Public Sector Disputes (Los Angeles: Institute of Industrial Relations, Univ. of California, 1976), p. A-1.

${ }^{23}$ Calif. Govt. Code, sec. 3505.2 (West Supp. 1970).

${ }^{24}$ Calif. Govt. Code, sec. 3548 (1976).

25 Governors Executive Order (1971), (Lab. Rel. Rep., sec. $14: 213$ SSL).

${ }^{26}$ Prentice Hall Editorial Staff, and International Personnel1 Management Association, "Impasse Techniques Survey," Public Personnel Administration/Labor Management Relations, 
Vol. I (Englewood Cliffs, N.J.: Prentice Hall, 1974), pp. 3139-3148.

27 Drachman, p. 38 .

${ }^{28}$ Wesley, p. 7 .

29 Robert G. Howlett, "Some Observations on Neutrals," in The Role of the Neutrals in Public Sector Disputes, ed. Howard J. Anderson (Washington, D.C.: Bureau of National Affairs, 1972), p. 61 .

30 Arnold M. Zack, "Improving Mediation and Fact-Finding in the Public Sector," Labor Law Journal, 30 (1970), 265.

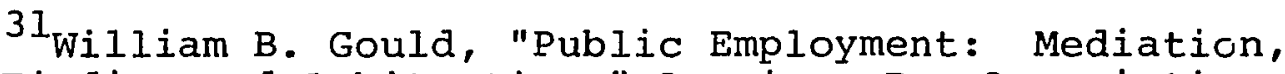
Fact-Finding and Arbitration," American Bar Association Journal, 55 (1969), 836 .

32 Zack, "I mproving Mediation," p. 262.

${ }^{33}$ Gould, p. 836 .

34 oregon School Boards Association, Impasse Resolution Techniques: Mediation and Fact-Finding (Salem, Ore.: Oregon School Boards Association, 1971), p. 4 .

${ }^{35}$ Gilroy and Sincropi, State-of-the Art, p. 58.

${ }^{36}$ Jacob Finkelman, "Fact-Finding, Its Values and Limitations: Comment," Arbitration and the Expanding Role of Neutrals. Proc. of the Twenty-Third Annual Meeting, National Academy of Arbitrators (Washington, D.C.: Bureau of National Affairs, 1971), p. 183.

37 Jean T. McKelvey, "Fact-Finding in Public Employment Disputes: Promise or Illusion?" Industrial and Labor Relations Review, 22, No. 4 (1969), 529.

${ }^{38}$ Hagburg and Levine, p. 236.

${ }^{39}$ George H. Hildebrand, "The Public Sector," in Frontiers of Collective Bargaining, ed. John Dunlop and Neil Chamberlain (New York: Harper, 1967), p. 147 .

${ }^{40}$ Simkin, Dynamics, p. 237. 
${ }^{41_{\text {Simkin, Dynamics, }}}$ p. 239.

${ }^{42}$ Simkin, Dynamics: p. 242.

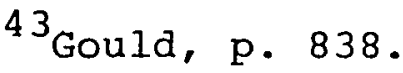

${ }^{44}$ Simkin, Dynamics, p. 241.

${ }^{45}$ William E. Simkin, "Fact-Finding: Its Values and Limitations," Arbitration and the Expanding Role of Neutrals. Proc. of the Twenty-Third Annual Meeting, National Academy of Arbitrators (Washington, D.C.: Bureau of National Affairs, 1970), pp. 167-168.

${ }^{46}$ Simkin, Dynamics, p. 239.

${ }^{47}$ Simkin, Dynamics, pp. 239-240.

${ }^{48}$ Howlett, p. 176.

${ }^{49}$ Bornstein, p. 5 .

50 Bornstein, p. 6 .

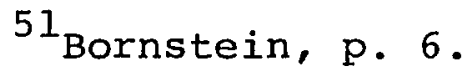

52 Howlett, pp. 178-179.

${ }^{53}$ Seamon, p. 126 .

${ }^{54}$ Simkin, "Fact-Finding," p. 171.

55 James C. Hill, "The Presidential Address," Arbitration and the Expanding Role of Neutrals. Proc. of the Twenty-Third Annual Meeting, National Academy of Arbitrators (Washington, D.C.: Bureau of National Affairs, 1970), p. 201.

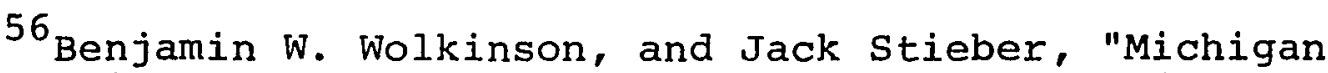
Fact-Finding Experience in Public Sector Disputes," The Arbitration Journal, 31 (1976), 245.

${ }^{57}$ Robert J. Jossen, "Fact-Finding: Is it Adjudication or Adjustment," The Arbitration Journal, 24 (1969), 112-113. 
58 Mckelvey, p. 531 .

${ }^{59}$ Arnold M. Zack, "Impasses, Strikes, and Resolutions," in Public Workers and Public Unions, ed. Sam Zagoria (Englewood Cliffs, N.J.: Prentice-Hall, 1972), p. 114.

${ }^{60} \mathrm{Hill}, \mathrm{p} .203$.

${ }^{61}$ Zack, "Impasses, Strikes, and Resolutions," p. 114.

62 Donald H. Wollett, "Some Facts and Fantasies About Public Employees Bargaining," in The Role of the Neutral in Public Employee Disputes, ed. Howard J. Anderson (Washington, D.C.: Bureau of National Affairs, 1972), p. 69.

${ }^{63}$ Robert E. Doherty, "Factfinding: A One-Eyed Man Lost Among the Eagles," Public Personnel Management, 5, No. 5 $(1976), 366$.

${ }^{64}$ Seamon, p. 129.

${ }^{65}$ Bornstein, p. 6 .

${ }^{66}$ Simkin, "Fact-Finding," p. 172.

67 McKelvey, p. 543. Jossen, p. 115.

${ }^{68}$ Zack, "Impasses, Strikes, and Resolutions," p. 112.

${ }^{69}$ Bornstein, p. 8 .

70 Edward B. Krinsky, "An Analysis of Fact-Finding as a Procedure for the Settlement of Labor Disputes Involving PubIic Employees," Diss. Univ. of Wisconsin 1969, n. pag.

$71_{\text {Wolkirson, and steiber, p. } 231 .}$

72 Byron Yaffe, and Howard Goldblatt, Factfinding in Public Employment Disputes in New York State: More Promise Than Illusion (Ithaca: School of Industrial Relations, Cornell Univ., 1971), p. 57.

${ }^{73}$ Bornstein, p. 8 .

${ }^{74}$ Zack, "Improving Mediation," p. 272. 
${ }^{75}$ William R. Word, "Fact-Finding in Public Employee Negotiations," Monthly Labor Review, 95 (1972), 63.

${ }^{76}$ wollett, p. 71 .

77 zack, "Improving Mediation," p. 272.

${ }^{78}$ Drachman, p. 39 .

79 Harold $W$. Davey, "The Use of Neutrals in the Public Sector," Labor Law Journal, 20 (1969), 283.

80 Jerry Wurf, "The Uses of Fact-Finding in Public Employee Dispute Settlement: The Union View," Arbitration and Social Changes. Proc. of the Twenty-Second Annual Meeting, National Academy of Arbitrators (Washington, D.C.: Bureau of National Affairs, 1970), p. 103.

${ }^{81}$ Yaffe and Goldblatt, p. 62.

82 Wolkinson and steiber, p. 247.

${ }^{83}$ Krinsky, p. 253

${ }^{84}$ Frank Elkouri, and Eaner Asper Elkouri, How Arbitration Works, 3rd ed. (Washington, D.C.: Bureau of National Affairs, 1973), p. 5 .

${ }^{85}$ Elkouri and Elkouri, p. 18.

${ }^{86}$ Merton C. Bernstein, "Alternatives to the strike in Public Labor Relations," Harvard Law Review, 85 (1971), 465.

${ }^{87}$ Robert C. Howlett, "Contract Negotiation Arbitration in the Public Sector," University of Cincinnati Law Review, 42 , No. $1(1973), 58-61$.

${ }^{88}$ Bernstein, p. 463 .

${ }^{89}$ Elkouri and Elkouri, p. 19.

90 Zack, "Impasses, Strikes, and Resolutions," p. 118.

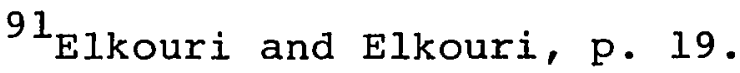


92 Hary Wellington, and Ralph $\mathrm{k}$. Winter, Jr., The Unions and the Cities (Washington, D.C.: The Brookings Institution, 1971), p. 177.

93 George W. Taylor, "Public Employment: Strikes or Procedures?" Industrial and Labor Relations Review, 20 $(1967), 632-6 \overline{36}$.

94 Wellington and winter, p. 180.

${ }^{95}$ Charles M. Rehmus, "Is a 'Final Offer' Ever Final?" Monthly Labor Review, 97 (1974), 44-45.

${ }^{96}$ Paul Somers, "An Evaluation of Final-offer Arbitration in Massachusetts," Journal of Collective Negotiations, 6 , No. 3 (1977), 209-210.

97 Peter Fenille, "Final-offer Arbitration and Negotiating Incentives," The Arbitration Journal, 32, No. 3 (1977), 216 .

${ }^{98}$ Sam Kagel and John Kagel, "Using Two New Arbitration Techniques," Monthly Labor Review, 95, No. 11 (1972), 12.

${ }^{99}$ Bernstein, pp. $465-468$.

100 Bernstein, pp. 470-471.

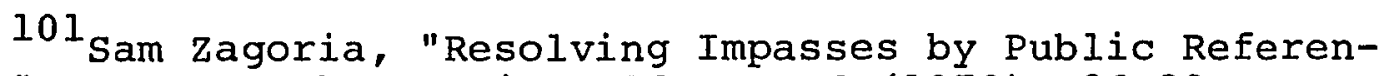
dum," Monthly Labor Review, 96, No. 6 (1973), 36-38. 
CHAPTER V

OREGON'S IMPASSE PROCEDURE AND

AGGREGATE DATA ANALYSIS

Oregon's impasse resolution process (as summarized in Figure 2 may be viewed as a filtering process where each step in the process contributes significantly to the orderly resolution of impasses, reduces the possibility of strike, and encourages the parties to settle voluntarily. Each step introduces a higher level of intervention by the neutral third party -- from suggestion to recommendation to public pressure to final determination by a third party.

The procedure follows the sequence of mediation, factfinding, and a cooling-off period. If these steps are unsuccessful they may be followed by strike for public employees other than those in the protective services (police, fire, and institutional guards) which go to compulsory arbitration.

The purpose of this chapter is to explain and analyze Oregon's impasse resolution procedure, with particular emphasis being placed on the fact-finding phase. An analysis of aggregate data is presented in order to describe the characteristics and ascertain the effectiveness of the factfinding process in Oregon. The impasse procedure is explained phase by phase as follows. 


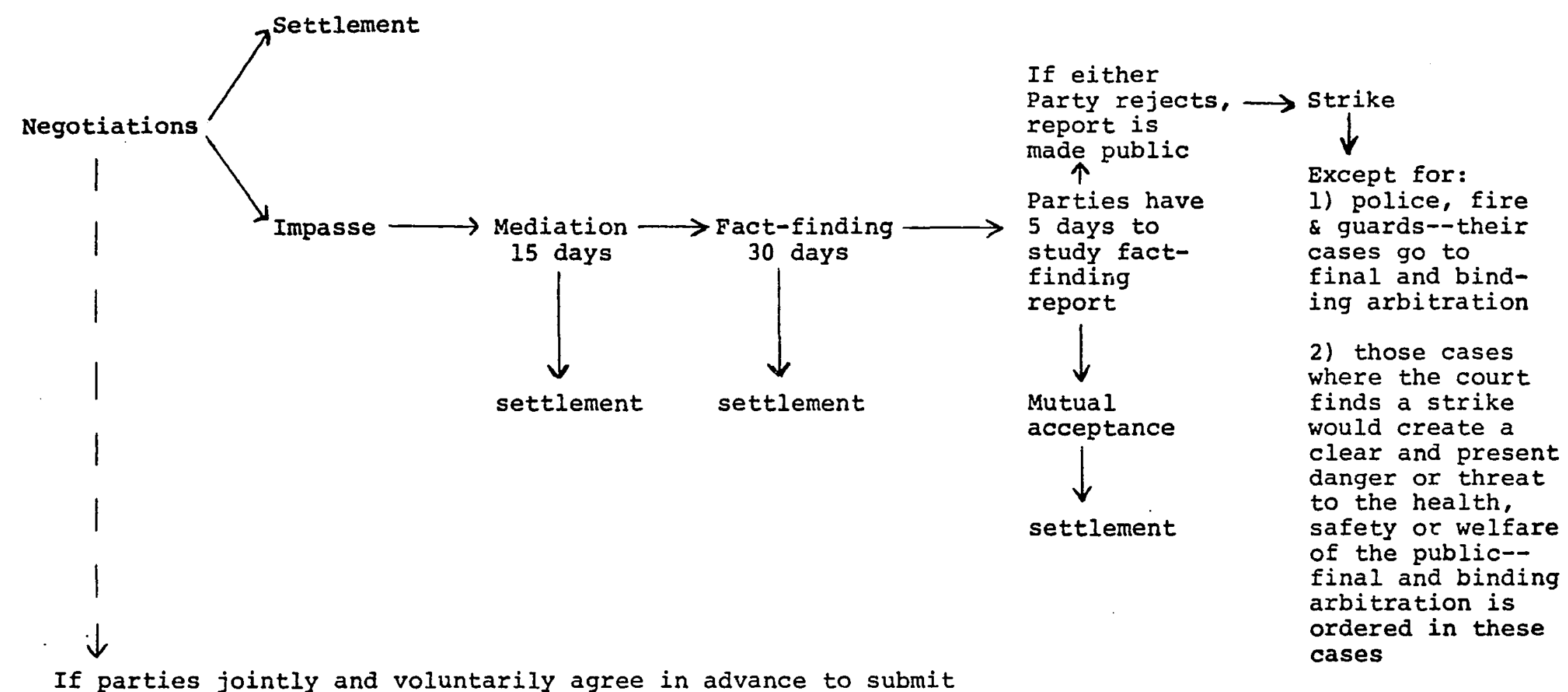

If parties jointly and voluntarily agree in advance to submit

any and all unresolved issues to final and binding arbitration

finding steps above may be skipped.

See HB2263, Sections.13, 14, 16, 17, 18, 19, 20, 21, 22

Figure 2. IMPASSE PROCEDURES UNDER OREGON'S PUBLIC SECTOR COLLECTIVE BARGAINING LAW

Source: Prisim III, Inc., Training Bulletin. (1974), p. 12 . 
Mediation

Mediation services are provided at no cost to the parties by the State Conciliation Service upon notification of an impasse by one or both of the parties, or when the Employment Relations Board (ERB) deems it appropriate. ${ }^{1}$ The State Conciliation Service is a division of ERB, and is staffed by full-time mediators. ${ }^{2}$

If ERB mediation efforts are not successful after fifteen days of mediation, fact-finding may be initiated by either of the parties or by the mediator if it is deemed appropriate, and in the public interest. 3

The law specifically states that if the parties wish they may at anytime voluntarily agree to submit any or all issues to final and binding arbitration. In this case the arbitration decision will supersede any mediation and/or fact-finding procedures. 4

\section{Fact-Finding}

The fact-finding procedure may be viewed in terms of the follwoing phases: selection and scheduling, the hearing, the report, and the parties' actions.

The Selection Phase. The law allows parties to mutually agree upon a fact-finder within five days of the ERB notification that fact-finding is to be initiated; otherwise ERB submits a list of five qualified neutrals to the parties. Each party then alternately strikes two names from the 1ist, with the remaining individual designated the fact-finder. 
In the cases where parties wish to have a panel of three fact-finders the ERB submits a list of seven qualified neutrals, the parties alternately strike two names, with the remaining individuals designated the fact-finders. 5

If in either case the parties do not notify the board of their choice within five days of receipt of the list, the ERB appoints a fact-finder(s). If only one party fails to notify, the ERB appoints a fact-finder from the remaining names on the 1ist. 6

The State Conciliation Service regulations state that a person may not serve as a fact-finder in a case where he has any personal interest, however, the parties may waive this disqualification in writing. Also the neutral is required to "disclose any circumstances likely to create a presumption of bias," and either party may disqualify him or waive the presumptive disqualification. 7

Scheduling. After the appointment, the fact-finder establishes the date, time, and location of the hearing. The parties must submit a written list of the issues to be submitted to fact-finding to the fact-finder at least seven days prior to the hearing.

The Hearing. The hearing is public, and like an arbitration hearing, structured. The role of the fact-finder is expected to be quasi-judicial by both parties and the state Conciliation Service, which discourages mediation efforts on the part of the fact-finder. 8 
During the hearing the fact-finder may administer oaths and provide all parties the opportunity to examine and cross examine all witnesses and to present any evidence pertaining to the dispute. 9 Any exhibits introduced by a party are filed with the fact-finder and a copy provided to the other party.

The Fact-Finders' Report. The report consists of written findings of fact and recommendations on all issues submitted. It is to be served within thirty days from the conclusion of the hearings. The report is delivered personally or by registered mail to the parties and the ERB. 10

The criteria of judgment used by fact-finders, although not specified in the law, are set forth in the rules of the State Conciliation Service to be the same as those required by arbitrators by the law. These criteria include: the ability to pay of the governmental unit; wages, hours and conditions of employment in comparative units; the consumer price index; and fringe benefits. ${ }^{11}$

The Parties' Actions. Acceptance of the report by the parties terminates the dispute. Acceptance is interpreted to mean acceptance of the recommendations on all issues submitted.

If the fact-finders' report has not been accepted by both parties within five working days after the parties receive the report and one or both reject the report, the ERB publicizes the report. However, if the parties agree to submit the impasse to final binding arbitration, or agree 
on settlement within those five days, the ERB will not publicize the report. ${ }^{12}$ Publication consists of releasing the report to the wire services rather than the home town newspaper.

In summary, fact-finding in oregon is a mandatory process with the parties equally bearing the cost of the factfinder. The parties may select or be involved in the selection of the fact-finder. The process is quasi-judicial, and requires specific criteria of judgment to be utilized in the findings and report. However, fact-finding is not the final step in oregon's impasse resolution process.

Cooling-off Period. When a fact-finding report is rejected the cooling-off period begins. This is the 30 day interim after fact-finding and before strike can be initiated. During this time it is not unusual for the Conciliation Service to engage in super-mediation efforts to help avoid a strike. Usually the mediator is the same one involved at the first step of mediation.

\section{Strike}

The strike is the final stage in Oregon's impasse resolution process (except for the protective services). In order to strike the mediation and fact-finding processes must have been exhausted; the thirty day cooling-off period must have passed; and an intent to strike notice submitted by the union ten days prior to the strike. ${ }^{13}$ 
Injunctive relief may be granted by the local circuit court upon petition by the employer, if the potential strike "creates a clear and present danger or threat to the health, safety, or welfare of the public."14 In this circumstance the dispute is submitted to final binding arbitration.

\section{Binding Interest Arbitration}

Binding interest arbitration is the final step for the protective services and in the case of a court injunction against a strike. This phase may be utilized only after mediation and fact-finding efforts have been exhausted. Selection of the arbitrator is simj.lar to that in factfinding, where the parties may select their own or strike names frcm a list provided by ERB. 15

The arbitrator, upon selection, establishes dates, times and location of the hearing. The parties must have specified the issues prior to the hearing. The hearing is formal and the criteria of judgment set forth in the law. 16

Within thirty days the arbitrator will issue his decision that is binding to both parties. Enforcement of the decision occurs through the circuit court by the insistance of either party or the ERB.

The law also allows parties to enter "into a collective bargaining agreement which provides for a compulsory arbitration procedure which is substantially equivalent" to the state statute. 17 
Summary

In summary, Oregon's impasse resolution process follows an elaborate sequence involving mediation, fact-finding, a cooling-off period, interest arbitration for protective services, and strike for other public employees. This sequence may be viewed as a filtering process where each step reduces the possibility of strike and encourages the parties to settle voluntarily.

Now with over four years experience, the fact-finding phase of this process has become controversial, and there are bills being prepared for presentation to the next legislature that would abolish fact-finding. ${ }^{18}$ The purpose of this study is to provide systematic investigation into the process. In particular, the intent of this study is to describe the nature and characteristics of Oregon's factfinding process and evaluate its effectiveness. In the remainder of this chapter aggregate data is considered and analyzed.

\section{METHODOLOGY FOR THE AGGREGATE DATA}

As discussed in the introductory chapter, data was collected from the fact-finding records of Oregon's State Conciliation Service. The years cover 1974 through 1977 and involved two hundred and thirty nine cases ( $\mathrm{n}=239$ ). Analysis of the aggregate data was conducted by utilizing frequency distributions and contingency tables (cross-tabulations) through the use of the sPSS Computer Program. The 
frequency tables provided absolute and percentage distributions indicating what has transpired over the four years. The contingency tables provide further understanding of relationships between variables. To aid in the judgment of whether an association exists, lambda (asymmetric) and Goodman-Kruskal's Tau have been utilized. ${ }^{19}$

Because of the home rule issue, the data related to cities and home rule counties is incomplete. In order to avoid a skewing of the aggregate data, home rule cases were dropped from much of the analysis. As a result no specific descriptions or analysis will be able to be made about cities; however, this should not detract from the description and analysis of the fact-finding process, which is the purpose of this study. 20

Because this data represents the total population of fact-finding cases between 1974-1977, observed differences are real and therefore merit discussion.

One final note, comparative data from other states will be introduced where it is possible and appropriate.

\section{ANALYSIS OF THE AGGREGATE DATA}

Table XVI shows the use of each phase of Oregon's factfinding process within the context of the entire impasse resolution procedure. The table reflects the total factfinding cases from 1974-1977 and categorizes that into home rule and all cases without home rule. This last category is divided into education and all other government cases. 
TABLE XVI

DISPOSITION OF CASES GOING TO IMPASSE IN OREGON, 1974-1977

\begin{tabular}{|c|c|c|c|c|c|c|c|c|c|c|}
\hline & $\begin{array}{c}\text { Media- } \\
\text { tion }\end{array}$ & $\begin{array}{c}\text { Fact } \\
\text { Finding } \\
\text { Initiated }\end{array}$ & $\begin{array}{l}\text { Settled } \\
\text { Before } \\
\text { Hearing }\end{array}$ & $\begin{array}{l}\text { Hearing } \\
\text { Held }\end{array}$ & $\begin{array}{c}\text { Report } \\
\text { Accepted }\end{array}$ & $\begin{array}{l}\text { Settled } W / 0 \\
\text { Mediation } \\
\text { After FF }\end{array}$ & $\begin{array}{c}\text { Settled W/ } \\
\text { Mediation } \\
\text { After FF } \\
\end{array}$ & $\begin{array}{c}\text { Arbitra- } \\
\text { tion }\end{array}$ & Strike & Missing* \\
\hline Total Cases & 874 & 239 & 75 & 153 & 25 & 12. & 82 & 7 & 7 & 31 \\
\hline Home Rule & - & 38 & 5 & 22 & 3 & 0 & 1 & 3 & 0 & 26 \\
\hline $\begin{array}{l}\text { All Cases } W / O \\
\text { Home Rule }\end{array}$ & - & 201 & 70 & 131 & 22 & 12 & 81 & 4 & 7 & 5 \\
\hline Education & 526 & 139 & 46 & 93 & 16 & 6 & 64 & NA & 5 & 2 \\
\hline $\begin{array}{l}\text { All Other } \\
\text { Government }\end{array}$ & - & 62 & 24 & 38 & 6 & 6 & 17 & 4 & 2 & 3 \\
\hline
\end{tabular}

Source: Data collected and tabulated from the file of the oregon State Conciliation Service Division

*Cases where disposition beyond initiation of fact-finding is unknown

-Data not avallable

NA Not applicable 
Due to the home rule issue only brief comments will be made about the total cases category, and most of the analysis will center on all the cases without home rule category.

\section{Total Cases}

Between 1974 and 1977,239 of the 874 cases going to mediation went unresolved and resulted in a request for fact-finding. These 239 cases represented 27.3 percent of the disputes going to mediation. That is, almost 73 percent of the cases going to mediation were resolved at that stage of impasse resolution. This is 21 percent higher than Drothing and Lipsky reported in their study of New York State's impasse procedure, where about 52 percent of the cases going to impasse were settled in mediation. 21

This in and of itself testifies to the success of the State Conciliation Service's mediation efforts and to the concept that the impasse procedure acts as a filtering process. This success is further demonstrated when one considers the service's role in post-fact-finding mediation (super-mediation) during the cooling-off period, which will be discussed later.

of the 239 requests for fact-finding, 75 (or 31.4 percent) had been resolved before the hearing. This is II percent higher than that reported by Steiber and Wolkinson in their Michigan study, where about 20 percent of the cases were settled before the hearing. 22 In oregon this is probably due to continuing mediation efforts, the cost of fact- 
finding, and the effort required to prepare for fact-finding. Further analysis regarding this will be presented later in this chapter.

In contrast, almost two-thirds of the 239 requests for fact-finding resulted in a hearing; and 11 (4.6 percent) are unaccounted for. The disposition of those cases going to hearing follows. This data is based upon the relative frequency since it is not adjusted for the missing cases.

of the 153 cases going to hearing, 25 (or 16.3 percent) resulted in both parties accepting the fact-finder's report. By way of comparison, the Drothing and Lipsky study showed about 36 percent of the fact-finder's reports in New York State were accepted without modification. 23 Detailed analysis will be presented later in this chapter as to the cause of such a low percentage of fact-finding reports being accepted in Oregon.

Twelve of the 153 cases (or 7.8 percent) were settled after the hearing without further mediation assistance. Another 7 (or 4.5 percent) went to binding arbitration and 7 (or 4.5 percent) went on to strike. Of the 31 cases where data is missing, 26 involve home rule cases, thus the rationale for leaving them out of the rest of the analysis. Although this dissertation concentrates on the cases excluding home rule, the data for the total cases suggests that Oregon's impasse resolution procedure does significantly reduce the number of impasses at each step, and that the process does result in very few strikes, as less than 1 
percent of the total cases going to impasse (mediation being the first step) go on to strike. Indications are that factfinding does contribute toward the reduction of strikes, as less than 3 percent of the cases where fact-finding has been initiated result in strike. Further analysis cannot be accomplished because the home rule cities which begin the process have a strong tendency to opt out at their convenience, as demonstrated by the missing data.

\section{All Cases Excluding Home Rule Cases}

Dropping home rule cases from Table XVI provides a clearer basis for analysis of the impasse process. The remainder of this study will be based upon this data base.

Mediation. Of the total non home rule cases going to impasse, about 77 percent are solved in the first step, mediation, which again testifies to the effectiveness of the State Conciliation Service's mediation efforts.

Fact-Finding. Fact-Finding was initiated (requested) 201 times. Of these 201 cases, 70 were settled before a hearing. As mentioned before this suggests that the threat of fact-finding encourages almost 35 percent of parties to resolve their differences rather than go to the expense, time, and uncertainty involved in the fact-finding hearing. Table XVI shows that during the years 1974-1977, about two-thirds of the request for fact-finding resulted in hearings and reports issued. The disposition of those 131 cases was as follows: 
(1) Reports accepted: 16.8 percent of the reports issued were accepted by both parties. This is not as high of a percent as theorists may like, however this is not necessarily an indication that the process does not work. Further analysis, including the numbers of issues involved and the views of the parties are needed in order to ascertain the effectiveness of the process. This will be accomplished in this and the following chapters.

(2) Settled without post-fact-finding mediation:

9.2 percent of the cases going to hearing were resolved by the parties themselves after one or both parties rejected the report.

(3) Settled with post-fact-finding mediation: 81 (or 62 percent) of the cases going to hearing were resolved by post-fact-finding mediation by the state Conciliation Service. This phase, often called "super-mediation," generates much interest and concern for two reasons. First, although the cooling-off period is required by oregon law, supermediation is not. It has evolved of necessity as the state Conciliation Service has interposed to protect the public interest. Second, over 62 percent of the cases going to a fact-finding hearing are not resolved without supermediation by the state Conciliation Service.

The intent of the fact-finding process is for the parties themselves, after objectively considering one anothers case, to agree on the fact-finder's report, or at the very least to use it as a basis for unassisted and 
voluntary resolution. However, this is not occurring in the majority of the cases. Later this study will consider why more reports are not accepted, whether something can be done to improve the acceptance ratio, and whether the heavy reliance on super-mediation means the fact-finding process is not useful.

Arbitration. Less than 4 percent of the cases going to a fact-finding hearing went on to binding arbitration after failing to resolve differences in the fact-finding stage. These four cases irvolved the public safety services of police and fire.

Strike. Of the 131 cases that went to a fact-finding hearing, 7 resulted in strike. The vast majority of the strikes (5 of 7 , or 71 percent) involved the education sector. When comparing the number of strikes to the number of cases where fact-finding was initiated it is found that only 3.5 percent of the 201 cases where fact-finding was initiated resulted in strike.

Before engaging in further analysis of the aggregate data, a discussion regarding the numbers and types of issues submitted to fact-finding is warranted.

\section{NUMBERS AND TYPES OF ISSUES}

The numbers and types of issues submitted to factfinding ranged from 1 to 92 . In order to identify the average number of issues, and the issues more frequently submitted, actual fact-finding reports were analyzed. The 
sample analyzed was based upon availability, and consisted of 18 of 38 non teaching reports and 81 of 93 teaching reports.

Numbers of Issues

Table XVII shows that the average number of issues in teaching cases is over twice as high as in non teaching cases. Supporting data may be found in Appendix C.

TABLE XVII

NUMBER OF ISSUES SUBMITTED TO FACT-FINDING, 1974-1977*

\begin{tabular}{lccc}
\hline & Teaching & $\begin{array}{c}\text { Non } \\
\text { Teaching }\end{array}$ & Tota 1 \\
\hline Mean & 17 & 7 & 15 \\
Median & 11 & 4 & 9 \\
Mode & 2 & 4 & 2 \\
\hline
\end{tabular}

*Based upon a sample of 99 of 139 reports issued.

These averages, especially in the teaching cases, are conservative numbers because one issue may involve several sub-issues. For example, the issue of salary might involve the sub-issues of 1) the base, 2) the form of the schedule (steps and columns), and 3) the increment between columns and steps. In addition, the following sub-issues may also arise from the salary issue: 1) automatic vs merit pay increases, 2) method to prove employees are to move to another step, 3) extra pay for M.A. and Ph.D. degrees, 4) ratio from 
top to bottom of scale, and 5) teachers not on the schedule. Thus, although salary is counted here as one issue for consistency, there are as many as eight sub-issues that might be involved, and therefore the averages in Table XVII are seen as conservative.

By way of comparison, Yaffe and Goldblatt found that in New York State the average number of issues in teaching and non teaching cases was 24 and 9 respectively. 24

The total average number of issues in oregon is 15, which is high considering that acceptance of a fact-findirg report requires both parties to agree to the recommendations on all issues submitted. This may have much to do with the high rejection rate in Oregon as compared to New York State where parties could reject only part of the report rather than the total report.

\section{Frequency of Issues}

Table XVIII and XIX show the issues most frequently submitted to fact-finding for teaching and non teaching cases. Both tables show that salary and insurance are by far the most often submitted issues. After salary and insurance there are differences in the main issues between teaching and non teaching cases. This is to be expected given the unique nature of the teaching field and the fact that it is regarded as a profession, not a vocation. It is interesting to note that grievance procedures are an issue in 41 percent of the teaching cases and in less than 20 
TABLE XVIII

FREQUENT ISSUES SUBMITTED IN TEACHING CASES, 1974-1977*

\begin{tabular}{|c|c|c|}
\hline Rank & Issue & Percent of Cases \\
\hline 1. & Salary & 95 \\
\hline 2. & Insurance & 86 \\
\hline 3. & Grievance & 41 \\
\hline 4. & Duration of Contract & 35 \\
\hline 5. & Teaching Calendar & 34 \\
\hline 5. & Extra Duty Pay & 34 \\
\hline 6. & Teacher Evaluation & 33 \\
\hline 7. & Fair Share & 31 \\
\hline 7. & Personal/Academic Freedom & 31 \\
\hline 8. & Non Teaching Schedule & 30 \\
\hline 8. & Lockout/Strike Clause & 30 \\
\hline 9. & Sick Pay & 29 \\
\hline 10 . & Just Cause & 28 \\
\hline 10. & Reduction in Staff & 28 \\
\hline 11. & Professional Leave & 26 \\
\hline 12 . & Teaching Day & 25 \\
\hline 12. & Teaching Load & 25 \\
\hline 13. & Union Rights & 24 \\
\hline 13. & Vacancies/Transfers & 24 \\
\hline 13. & Management Rights & 24 \\
\hline 14. & Personal Leave & 23 \\
\hline 14. & Maintenance of Standards & 23 \\
\hline 14. & Tuition Reimbursement & 23 \\
\hline 15. & Classroom Control/Discipline & 18 \\
\hline
\end{tabular}

*Based upon a sample of 81 of 93 reports issued 
TABLE XIX

MOST FREQUENT ISSUES SUBMITTED IN NON TEACHING CASES*

\begin{tabular}{|c|c|c|}
\hline Rank & Issue & Percent of Cases \\
\hline 1. & Salary & 88 \\
\hline 2. & Insurance & 61 \\
\hline 3. & Vacation & 44 \\
\hline 3. & Status of Agreement & 44 \\
\hline 4. & Sick Leave & 28 \\
\hline 4 & Holiday & 28 \\
\hline 5 . & Paid Negotiating Time & 22 \\
\hline
\end{tabular}

percent of the non teaching cases. It seems teachers are having to fight hard to gain many rights that are accepted as normal in other occupations.

In summary, the number of issues involved in Oregon's fact-finding cases range from 1 to 92 , with an average of 15 issues per case. The impact such a high number of issues has on the process will be discussed on occasion in the next portion of this chapter that deals with the characteristics of the fact-finding phase.

\section{CHARACTERISTICS OF FACT-FINDING PHASES}

Given this overview of the fact-finding process more detailed information was obtained from frequency distributions and cross tabulations of the variables. Although several apprcaches are possible, this study will consider 
in sequence each phase of the fact-finding process in terms of the parties involved and their actions.

The Initiation or Request Phase

Table XVI shows over 69 percent of the requests for fact-finding came from the education sector, while the remaining 30.8 percent of the requests were made by all other governments (special districts, county and state). By way of comparison Yaffe and Goldblatt found in their New York study that about 83 percent of the fact-finding cases occurred in the education sector; also Steiber and Wolkinson found that in Wisconsin about 74 percent were in education. 25 Analysis of requests for fact-finding by employee organization and type of government follows.

Requests by Employee Organization. Table XX shows the employee organization that accounted for the majority (57.2 percent) of fact-finding cases was the Oregon Education Association (OEA), which represents all but a few public school teacher bargaining units $(\mathrm{K}-12)$, some Intermediate Education Districts, and a few community colleges. This high usage is not surprising as public school teachers have the highest incidence of organization and number of contacts in oregon's public sector (see the penetration study in Chapter III). The Oregon School Employees Association (School Employees), which represents non teaching staff in many public schools (such as secretaries, aids, cooks, bus drivers and custodians) accounts for 5.5 percent of the total cases. 
TABLE XX

OREGON FACT-FINDING REQUESTS BY EMPLOYEE ORGANIZATIONS, 1974-1977

\begin{tabular}{lcr}
\hline Employee Organization & Frequency & Percent \\
\hline OEA & 115 & 57.2 \\
AFSCME & 23 & 11.4 \\
OSEA (Education) & 11 & 5.5 \\
Other Teachers & 6 & 3.0 \\
Fire (IAFF) & 4 & 2.0 \\
Police & 1 & 0.5 \\
Sheriff & 5 & 2.5 \\
ILWU & 6 & 3.0 \\
Labor & 1 & 0.5 \\
ONA & 3 & 1.5 \\
Other (Misc.) & 19 & 9.5 \\
OSEA (state) & 8 & 4.0 \\
Total & & 100.6 \\
\hline
\end{tabular}


The organization involving the second highest number of requests is the American Federation of State, county and Municipal Employees (AFSCME), with 11.4 percent of the requests. The Oregon State Employee Association (State Employees) accounted for 4.0 percent of the requests, the ILWU (Long Shoremens' union for the Port of Portland special district) for 3.0 percent, and various others for the remaining. Of special interest is the reduction in the percent of police and fire cases once the home rule cases were dropped from the study. Police decreased from 8 to 1 cases and fire from 17 to 4 cases; this reflects the cities' dislike for compulsory arbitration, which is their professed reason for using their home rule status to avoid the state collective bargaining law.

Requests by Type of Government. Table XXI shows the type of government employer most involved in fact-finding was public schools. Public schools account for 58.7 percent of the requests for fact-finding. Counties account for 14.4 percent, special districts for 8.0 percent, state government for 8.5 percent, community colleges for 7.0 percent, higher education for 2.9 percent, and IED's for 1.5 percent of the requests for fact-finding.

It is interesting to note that special districts have about the same frequency of requests for fact-finding as the state and community colleges, yet the penetration rate (see Table XV) in: special districts was very low compared to the other two areas. This might be a topic for further research. 
TABLE XXI

OREGON FACT-FINDING REQUESTS BY TYPE OF GOVERNMENT (EMPLOYER)， 1974-1977

\begin{tabular}{lcr}
$\begin{array}{c}\text { Type of } \\
\text { Government Employer }\end{array}$ & Frequency & Percent \\
\hline Public School & 118 & 58.7 \\
IED & 2 & 1.5 \\
Community College & 14 & 7.0 \\
Higher Education & 4 & 2.9 \\
Special District & 16 & 8.0 \\
City & 0 & 0.0 \\
County & 29 & 14.4 \\
State & 17 & 8.5 \\
Total & 201 & 101.0
\end{tabular}

Requests by Year. Table XXII shows the incidence of requests by year. The change from 1974 to 1975 is 55 percent, from 1975 to 1976 no change, and from 1976 to 1977 an increase in the number of fact-finding requests of almost 65 percent. This increasing usage reflects the newness of the process, growing unionism and familiarity. That is, as more unions became certified and engaged in collective bargaining (and thus impasses) they have become more familiar with the process and less shy of using fact-finding. 
TABLE XXII

OREGON FACT-FINDING REQUESTS BY YEAR

\begin{tabular}{ccc}
\hline Year & Frequency & Percent \\
\hline 1974 & 27 & 13.4 \\
1975 & 49 & 24.4 \\
1976 & 49 & 24.4 \\
1977 & 76 & 37.8 \\
& & \\
Total & 201 & 100.0 \\
\hline
\end{tabular}

Summary of the Initiation or Request Phase. In summarizing the data relating to the initiation or request phase it has been shown that almost 70 percent of all fact-finding requests came from the education sector. The employee organization that accounted for the greatest share of requests was the OEA, followed by AFSCME, with many others accounting for less than 5 percent each. The type of government most involved was the public schools, followed by counties, special districts, and state government. Furthermore, there has been yearly percentage increases in fact-finding requests from 1974 through 1977. All requests for factfinding do not result in a hearing, rather many are settled before the hearing. This phase is discussed next.

\section{The Settled Before Hearing Phase}

As Table XVI showed, about 35 percent of the cases were resolved before a hearing. The question was posed as to 
whether the organization or the type of government involved was associated with a case being settled before the hearing; the thought being that this might be an indication of good faith bargaining and general belief in the collective bargaining process.

Table XXIII shows a cross tablilation of cases settled before hearing by sector. In this table education was collapsed into one group and all other government into another. Although edication accounted for about 66 percent of the total cases settled before hearing, the propensity to settle before hearing was almost identical for both sectors. It is concluded, then, that the propensity for a case to be settled before the hearing is not a function of its mission (e.g. education vs. other government). Other cross tabulations were run to observe any relation between particular employee organizations and governmental types, and cases settled before hearing.

\section{Settled Before Hearing by Employee Organizations.}

Table XXIV shows a cross tabulation between the employee organizations and the cases settled before hearing. The table reveals some real differences since OEA settled before hearing in about 30 percent of their cases, AFSCME in about 48 percent of their cases, the School Employees (OSEA-Ed) in about 64 percent of their cases, and the nurses (ONA) in 67 percent of their cases (there were only 3). Some organizations had a very low settled before hearing record, for example the ILWU was not involved in any cases settled 
before hearing, and the State Employees (OSEA-State) settled before hearing in only 14 percent of their cases.

When statistical association was measured, lambda was

0.7 indicating that the employee organization and settled before hearing actions are associated, but that the association is mild. Whether this association is due to the leadership of the employee organization, tradition, or other factors are questions that remain for further research.

TABLE XXIII

OREGON FACT-FINDING CASES SETTLED BEFORE

HEARING BY SECTOR, 1974-1977

\begin{tabular}{lcccc}
\hline \hline Sector & $\begin{array}{c}\text { Settled } \\
\text { Before Hearing }\end{array}$ & $\begin{array}{c}\text { Not Settled } \\
\text { Before Hearing }\end{array}$ & Total \\
\hline $\begin{array}{l}\text { Education } \\
\text { Other } \\
\text { Government }\end{array}$ & $46(33.1)$ & $93(66.9)$ & $139(100)$ \\
& $24(38.7)$ & $38(61.3)$ & $62 \quad(100)$ \\
Tota] & $70(34.8)$ & $131(65.2)$ & $10.1 \quad(100)$
\end{tabular}

Lambda (asymmetric) $=0.00$ with settled before hearing dependent

Goodman-Kruskai Tau $=.003$ with settled before hearing dependent 
TABLE XXIV

OREGON FACT-FINDING CASES SETTLED BEFORE HEARING BY EMPLOYEE ORGANIZATION, 1974-1977

\begin{tabular}{|c|c|c|c|c|c|c|}
\hline \multirow{2}{*}{$\begin{array}{l}\text { Employee } \\
\text { Organization } \\
\text { OEA }\end{array}$} & \multicolumn{2}{|c|}{$\begin{array}{l}\text { Settled } \\
\text { Before Hearing }\end{array}$} & \multicolumn{2}{|c|}{$\begin{array}{l}\text { Not settled } \\
\text { Before Hearing }\end{array}$} & \multicolumn{2}{|c|}{ Total } \\
\hline & 35 & $(30.4)$ & 80 & $(69.6)$ & 115 & $(100)$ \\
\hline AFSCME & 11 & $(47.8)$ & 12 & $(52.2)$ & 23 & $(100)$ \\
\hline OSEA (Education) & 7 & $(63.6)$ & 4 & $(36.4)$ & 11 & $(100)$ \\
\hline Other Teachers & 3 & $(50.0)$ & 3 & $(50.0)$ & 6 & $(100)$ \\
\hline Fire (IAFF) & 1 & $(25.0)$ & 3 & $(75.0)$ & 4 & $(100)$ \\
\hline Police & 0 & $(0.0)$ & 1 & $(100.0)$ & 1 & $(100)$ \\
\hline Sheriff & 2 & $(40.0)$ & 3 & $(60.0)$ & 5 & $(100)$ \\
\hline I.I.W.U. & 0 & $(0.0)$ & & $(100.0)$ & 6 & $(100)$ \\
\hline Labor & 1 & $(100.0)$ & 0 & $(0.0)$ & 1 & $(100)$ \\
\hline ONA & 2 & $(66.7)$ & 1 & $(33.3)$ & 3 & $(100)$ \\
\hline $\begin{array}{l}\text { Other (Misc.) } \\
\text { Independent }\end{array}$ & 7 & $(36.8)$ & 12 & $(63.2)$ & 19 & $(100)$ \\
\hline OSEA (state) & 1 & $(14.3)$ & 6 & $(85.7)$ & 7 & $(100)$ \\
\hline Total & 70 & $(34.8)$ & 131 & $(65.2)$ & 201 & $(100)$ \\
\hline
\end{tabular}

Lambda (asymmetric) $=.071$ with settled before hearing dependent 
Settled Before Hearing by Type of Government. Table xxV provides a cross tabulation between the type of government, and the cases settled before hearing. Again real differences are shown as public schools settled before hearing in 38 percent of their cases, community colleges in 36 percent, higher education 50 percent, counties in 48 percent, and the state in 41 percent; while special districts settled before hearing in abcut 19 percent of their cases. In spite of these differences little statistical association was found since lambda $=0$ and Goodman-Kruskai tau $=.026$.

Settled Before Hearing by Population and Census Type. The question was posed as to whether the population or census type (rural, suburban, urban) had any relation to cases being settled before hearing. Table XXVI shows a fairly even distribution (29-40 percent) between cases settled before hearing and population categories. There is no apparent association between population and settled before hearing as lambda $=0$. Table XXVII is a cross tabulation between settled before hearing and census type. It shows a similar distribution (27-34 percent) and that no significant difference between urban, suburban and rural areas exists with respect to their propensity to settle before hearing.

Summary of the Settled Before Hearing Phase

In summary, 35 percent of the cases were settled before the fact-finding hearing. There is a mild association between employee organizations and settled before hearing 
TABLE XXV

OREGON FACT-FINDING CASES SETTLED BEFORE HEARING BY TYPE OF GOVERNMENT EMPLOYER, 1974-1977

\begin{tabular}{|c|c|c|c|c|}
\hline $\begin{array}{l}\text { Type of } \\
\text { Government } \\
\text { Employer }\end{array}$ & $\begin{array}{l}\text { Settled } \\
\text { Before Hearing }\end{array}$ & $\begin{array}{l}\text { Not Settled } \\
\text { Before Hearing }\end{array}$ & & otal \\
\hline Public School & $38 \quad(32.2)$ & $80 \quad(67.8)$ & 118 & $(100)$ \\
\hline IED & $1(33.3)$ & $2(66.7)$ & 3 & $(100)$ \\
\hline Community College & $5(35.7)$ & $9(64.3)$ & 14 & $(100)$ \\
\hline Higher Education & $2(50.0)$ & $2(50.0)$ & 4 & $(100)$ \\
\hline Special Districts & $3(18.8)$ & $13(81.3)$ & 16 & $(100)$ \\
\hline County & $14(48.3)$ & $15(51.7)$ & 29 & $(100)$ \\
\hline State & $7(41.2)$ & $10 \quad(58.8)$ & 17 & $(100)$ \\
\hline Total & $70(34.8)$ & $131 \quad(65.2)$ & 201 & $(100)$ \\
\hline
\end{tabular}

Lambda (asymmetric) $=.000$ with settled before hearing dependent

Goodman-Kruskal tau $=.026$ with settled before hearing dependent 
TABLE XXVI

OREGON FACT-FINDING CASES SETTLED BEFORE HEARING BY POPULATION CATEGORY, 1974-1977

\begin{tabular}{lcccc}
\hline $\begin{array}{l}\text { Population } \\
\text { Category }\end{array}$ & $\begin{array}{l}\text { Settled } \\
\text { Before Hearing }\end{array}$ & $\begin{array}{l}\text { Not Settled } \\
\text { Before Hearing }\end{array}$ & Total \\
\hline $\begin{array}{l}\text { Under 2,500 } \\
2,500-10,000\end{array}$ & $16(28.6)$ & $15(71.4)$ & $21(100)$ \\
$10,000-50,000$ & $21(32.8)$ & $24(60.0)$ & $40(100)$ \\
Over 50,000 & $15(30.0)$ & $35(70.0)$ & $50(100)$ \\
\cline { 2 - 6 } & $58(33.1)$ & $117(66.9)$ & $175(100)$ \\
\hline
\end{tabular}

Lambda (asymmetric) $=0.000$ with settled before hearing dependent

Goodman-Kruskal tau $=0.007$ with settled before hearing dependent

Missing observations $=26$ 
TABLE XXVII

OREGON FACT-FINDING CASES SETTLED BEFORE HEARING BY CENSUS TYPE, 1974-1977

\begin{tabular}{lcccc}
\hline & $\begin{array}{l}\text { Settled } \\
\text { Before Hearing }\end{array}$ & $\begin{array}{l}\text { Not Settled } \\
\text { Before Hearing }\end{array}$ & Total \\
\hline Rural & $6(27.3)$ & $16(22.7)$ & $22(100)$ \\
Suburban & $7(33.3)$ & $14(66.7)$ & $21(100)$ \\
Urban & $45(34.1)$ & $87(65.9)$ & $132(100)$ \\
$\quad-1$ & $58(33.1)$ & $117(66.9)$ & $175(100)$
\end{tabular}

Lambda (asymmetric) $=0.000$ with settled before hearing dependent

Goodman-Kruskal tau $=0.002$ with settled before hearing dependent

Missing observations $=26$ 
actions; of the heavy users, the School Employees and AFSCME are more prone to settle before the hearing than the OEA or State Employees. Among governmental types there is little statistical association measured, although special districts are not as prone to settle before hearing as other government types.

The Parties' Action Phase

Given that the intent of issuance of a fact-finder's report is its potential acceptability, much consideration is given as to which parties accept reports and the possible factors that may influence such actions. Table XVI showed that of the 131 cases going to hearing only 22 (about 17 percent) were accepted by both of the parties. The question then was posed, are there significant differences between the parties' action and the parties themselves; and furthermore what effect, if any, does population, census type, time, and the fact-finder have on the parties' actions. Employee and Employer Action. Table XXVIII shows employee and employer action on fact-finding reports from 1974-1977. It shows employees have a higher acceptance rate and a lower rejection rate than employers. Employees accepted reports in 48 percent of the cases, while employers accepted in 34 percent of the cases. Employees rejected in 24 percent of the cases while employers rejected in almost 53 percent of the cases. These differences are partially explained by the interviews in later chapters of this 
dissertation, which indicate that some major users of factfinding may have had particular strategies in mind before the reports were issued. Another explanation of such high rejection rates lies in the large amount of issues involved in many cases. With a conservative average of 15 issues per case the odds are against both parties agreeing on the recommendations on every issue, which is required for the report to be accepted. Further analysis will be presented with respect to particular employer and employees' propensity to accept or reject fact-finding reports. Of immediate interest is the No Action category.

TABLE XXVIII

EMPLOYEE AND EMPLOYER ACTION ON OREGON

FACT-FINDING REPORTS, 1974-1977

\begin{tabular}{|c|c|c|c|c|c|c|}
\hline & \multicolumn{5}{|c|}{ Action } & \multirow[b]{2}{*}{ Total } \\
\hline & & $\begin{array}{l}\text { Accept } \\
\text { Report }\end{array}$ & & $\begin{array}{l}\text { Reject } \\
\text { Report }\end{array}$ & $\begin{array}{c}\text { No } \\
\text { Action }\end{array}$ & \\
\hline Employee & 62 & $(48.1)$ & 31 & $(24.0)$ & $36 \quad(27.9)$ & $131(100)$ \\
\hline Employer & 44 & $(34.1)$ & 68 & $(52.7)$ & $17(13.2)$ & $131(100)$ \\
\hline
\end{tabular}

No Action refers to a party not notifying ERB of their acceptance or rejection of a fact-finders' report, or wording it in such a way as to neither accept nor reject. Employees were involved in no action in almost 28 percent of the cases while employers were in 13 percent of the cases. 
This category is not technically possible because the law requires the parties to notify ERB within five working days after receipt of the report of their acceptance or rejection. What appears to have happened is that the parties (in particular the employee groups) desire to bide their time, hoping circumstances change so they might secure a more acceptable solution. Because the ERB cannot publish a report unless one party rejects, the parties prevent publication by taking no action (it is not a reject and therefore the report is not made public).

ERB in the meantime has no power to punish the parties for not meeting the requirement of the law in terms of their notification of action. It may be questionable whether ERB would help the process by insisting on parties meeting this requirement; however in this author's view such time lines and requirements should be met as the intent of the law is clear. The parties have a responsibility to play by the rules and not blatantly use the process for strategic reasons and bypass the intent of the law through a loophole, or through lack of enforcement powers by ERB, and/or followup procedures by the State Conciliation Service Division. Employee Action. Table XXIX shows a cross tabulation between education cases and all other government cases with employee action. This shows that employee groups in education, compared to those in other government units, have a higher propensity to accept fact-finders' reports (51.1 vs. 40.5 percent), about the same tendency to reject, and a 
lower propensity for no action (26.I vs. 32.4 percent). Although these differences are present, lambda $=0$ and therefore there is no apparent statistical relationship between the sector and employee action.

TABLE XXIX

SECTOR BY EMPLOYEE ACTION ON OREGON

FACT-FINDING REPORTS, 1974-1977

\begin{tabular}{llllllll}
\hline & \multicolumn{5}{c}{ Employee Action } \\
\cline { 2 - 6 } $\begin{array}{l}\text { Sector } \\
\text { Accept } \\
\text { Report }\end{array}$ & $\begin{array}{c}\text { Reject } \\
\text { Report }\end{array}$ & $\begin{array}{c}\text { No } \\
\text { Action }\end{array}$ & Total \\
\hline $\begin{array}{l}\text { Education } \\
\begin{array}{l}\text { Other } \\
\text { Government }\end{array}\end{array}$ & $47(51.1)$ & 21 & $(22.8)$ & 24 & $(26.1)$ & 92 & $(100)$ \\
& 15 & $(40.5)$ & 10 & $(27.0)$ & 12 & $(32.4)$ & 37 (100)
\end{tabular}

Lambda (asymmetric) $=.000$ with employee action dependent Goodman-Kruskal tau $=.0054$ with employee action dependent Missing observations $=2$

In order to analyze particular employee groups' actions, a cross tabulation between employee organizations and employee actions is provided in Table XXX. This table shows that the education sector unions (OEA, School Employees, and other teachers) have an acceptance rate of over 50 percent, which is much higher than the ILWU with a 33 percent acceptance, but less than State Employees with a 60 percent acceptance rate. An interesting observation is the state employees no action rate which is 40 percent, and their rojection rate of zero. OEA also demonstrated a high no action 
TABLE XXX

EMPLOYEE ORGANIZATION BY EMPLOYEE ACTION ON

OREGON FACT-FINDING REPORTS, 1974-1977

\begin{tabular}{|c|c|c|c|c|c|c|}
\hline \multirow{3}{*}{$\begin{array}{l}\text { Employee } \\
\text { Organization } \\
\text { OEA }\end{array}$} & \multicolumn{4}{|c|}{ Employee Action } & & \\
\hline & $\begin{array}{l}\text { Accept } \\
\text { Report }\end{array}$ & \multicolumn{2}{|c|}{$\begin{array}{l}\text { Reject } \\
\text { Report }\end{array}$} & $\begin{array}{l}\text { No } \\
\text { Action }\end{array}$ & \multicolumn{2}{|c|}{ Total } \\
\hline & $41 \quad(51.3)$ & 16 & $(20.0)$ & $23(28.8)$ & 80 & $(100)$ \\
\hline AFSCME & $5(41.7)$ & 6 & $(50.0)$ & $1(8.3)$ & 12 & $(100)$ \\
\hline $\begin{array}{l}\text { OSEA } \\
\text { (Education) }\end{array}$ & $2(50.0)$ & 2 & $(50.0)$ & $0(0.0)$ & 4 & $(100)$ \\
\hline $\begin{array}{l}\text { Other } \\
\text { Teachers }\end{array}$ & $2(100.0)$ & 0 & $(0.0)$ & $0(0.0)$ & 2 & $(100)$ \\
\hline Fire (IAFF) & $0(0.0)$ & 1 & $(33.3)$ & $2(66.7)$ & 3 & $(100)$ \\
\hline Police & $0(0.0)$ & 1 & $(100.0)$ & $0(0.0)$ & 1 & $(100)$ \\
\hline Sheriff & $0(0.0)$ & 1 & $(33.3)$ & $2(66.7)$ & 3 & $(100)$ \\
\hline ILWU & $2(33.3)$ & 3 & $(50.0)$ & $1(16.7)$ & 6 & $(100)$ \\
\hline ONA & $1(100.0)$ & 0 & $(0.0)$ & $0(0.0)$ & 1 & $(100)$ \\
\hline Other & $6(50.0)$ & 1 & $(8.3)$ & $5(41.7)$ & 12 & $(100)$ \\
\hline OSEA (state) & $3(60.0)$ & 0 & $(0.0)$ & $2(40.0)$ & 5 & $(100)$ \\
\hline Total & $62(48.1)$ & 31 & $(24.0)$ & $36 \quad(27.9)$ & 129 & $(100)$ \\
\hline
\end{tabular}

Lambda (asymmetric) $=0.104$ with employee action dependent Missing observations $=2$ 
rate of 28.8 percent, but not nearly as high as the no action rate of the fire and sheriff groups with 67 percent. Although Table XXVIII shows that employees overall accept fact-finders' reports 48 percent of the time, Table $\mathrm{XXX}$ shows the protective service employee groups (police, fire and sheriff) did not accept one report. An explanation of this is that with binding arbitration as a final step these organizations may view the fact-finders' report as just another step, and may reason that they have everything to gain and nothing to lose by going on to arbitration. This is because they hope that the fact-finders' report will be the minimum and not the maximum recommended by the arbitrator. The following chapters of this dissertation will deal more with this observation.

When testing for association lambda was .10 which indicates there is a mild association between employee organization and action.

Table XXXI relates employee action and employer in order to attempt to observe whether employee action depends on the type of government they are dealing with. In this case there is a relationship, however it is mild as lambda = .06. Table XXXI also shows that in public school cases employees accept 52 percent of the reports, in community colleges 33 percent, in county 53 percent, in state 44 percent and in special districts 23 percent of the reports. Of interest is the higher rate of no action among the state, county and community college cases as compared to public 
TABLE XYXI

TYPE OF GOVERNMENT BY EMPLOYEE ACTION ON

OREGON FACT-FINDING REPORTS, 1974-1977

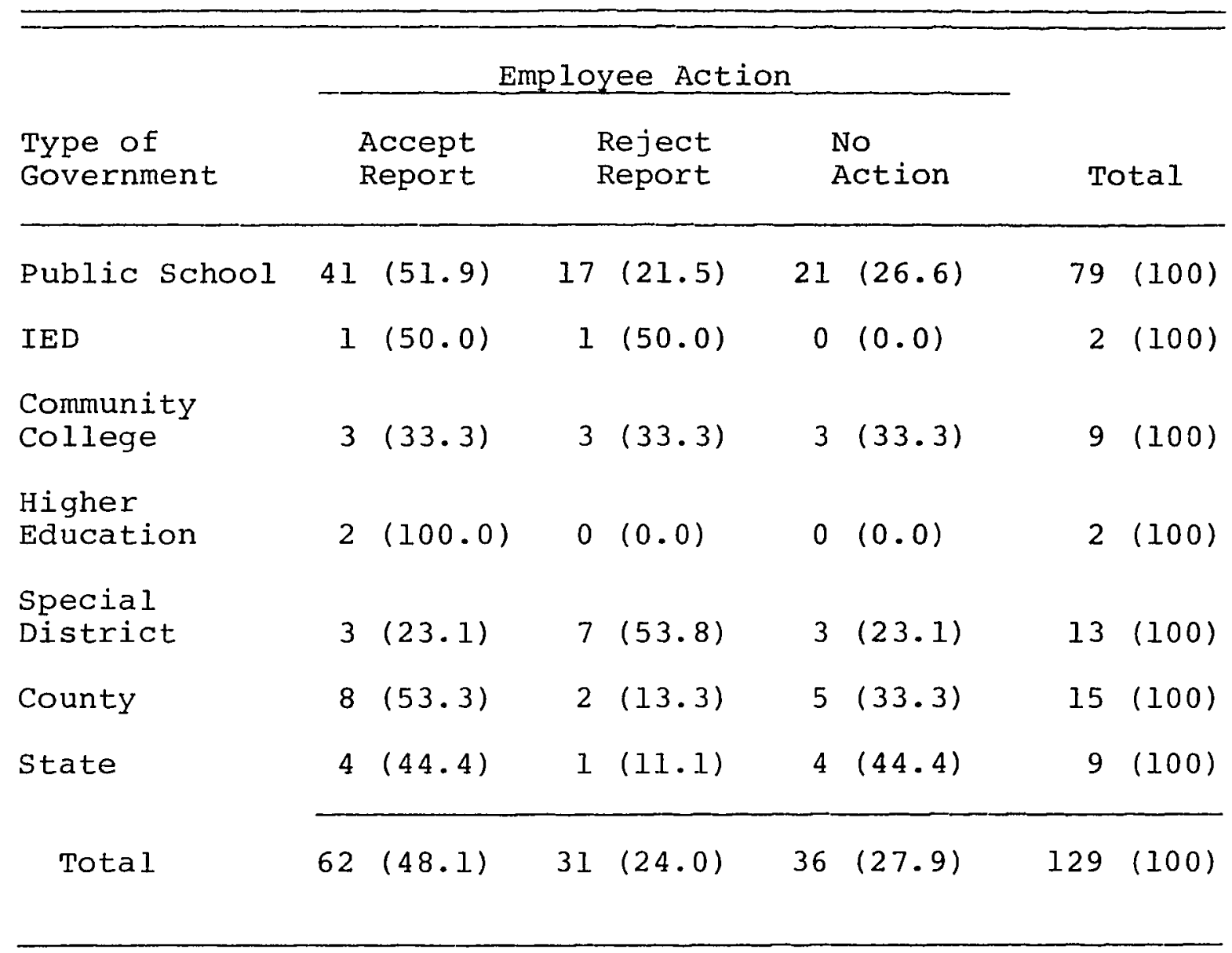

Lambda (asymmetric) $=0.059$ with employee action dependent Missing observations $=2$ 
schools and special districts.

Employer Action. Table XXXII is a cross tabulation of employer action and government sector. Employers in the education sector had an acceptance rate of 31.5 percent and a rejection rate of 57.6 percent compared to other governments' identical acceptance and rejection rate of 40.5 percent. This means the propensity for employers in the education sector to accept fact-finding reports is 9 points lower than other government, and their propensity to reject 17.1 points higher. An interesting observation is that the no action rate of other governments is 8 points higher than that of education, which means those in the other government category prefer no action to reject in many cases. Neither group used no action as much as their employee adversaries. Although these differences exist there is no apparent association between employer action and the sector since lambda $=0$.

To analyze particular employer actions a cross tabulation between type of government and employer actions is provided in Table XXXIII. Of particular interest is the relatively low percent of acceptances by community college employers as compared to public school, special district, county, and state governments. Whether this is coincidental or a result of a strategy by the OCCA (an affiliation of community college boards and presidents) is a matter of speculation. Lambda was .03 which indicates association, but very mild. 
TABLE XXXII

SECTOR BY EMPLOYER ACTION ON OREGON

FACT-FINDING REPORTS, 1974-1977

\begin{tabular}{|c|c|c|c|c|c|c|c|}
\hline \multirow{3}{*}{$\frac{\text { Sector }}{\text { Education }}$} & \multicolumn{6}{|c|}{ Employer Action } & \multirow[b]{2}{*}{ Total } \\
\hline & \multirow{2}{*}{\multicolumn{2}{|c|}{$\begin{array}{l}\begin{array}{l}\text { Accept } \\
\text { Report }\end{array} \\
29(31.5)\end{array}$}} & \multicolumn{2}{|c|}{$\begin{array}{l}\text { Reject } \\
\text { Report }\end{array}$} & \multicolumn{2}{|c|}{$\begin{array}{c}\text { No } \\
\text { Action }\end{array}$} & \\
\hline & & & 53 & $(57.6)$ & 10 & $(10.9)$ & $92(100)$ \\
\hline $\begin{array}{l}\text { Other } \\
\text { Government }\end{array}$ & 15 & $(40.5)$ & 15 & $(40.5)$ & 7 & $(18.9)$ & $37(100)$ \\
\hline Total & 44 & $(34.1)$ & 68 & $(52.7)$ & 17 & $(13.2)$ & $(100)$ \\
\hline
\end{tabular}

Lambda (asymmetric) $=0.000$ with employer action dependent Goodman-Kruskal tau $=0.015$ with employer action dependent Missing observations $=2$

Table XXXIV is a cross tabulation of employer action and the employee group they are dealing with. It shows that the relationship between employer action and the adversary employee organization is among the strongest in this study. Lambda is .21 which indicates a moderate association, thus some particular observations warrant discussion.

First within education, public school employers rejected reports involving the OEA 58 percent of the time, while they rejected those involving non-teaching staff (OSEA-Ed) in 75 percent of the cases. This may be an indication that public school boards find it even more difficult to accept collective bargaining among non-teaching employees than they do teache:rs. This may be due to the previous (and 
TABLE XXXIII

TYPE OF GOVERNMENT BY EMPLOYER ACTION ON

OREGON FACT-FINDING REPORTS, 1974-1977

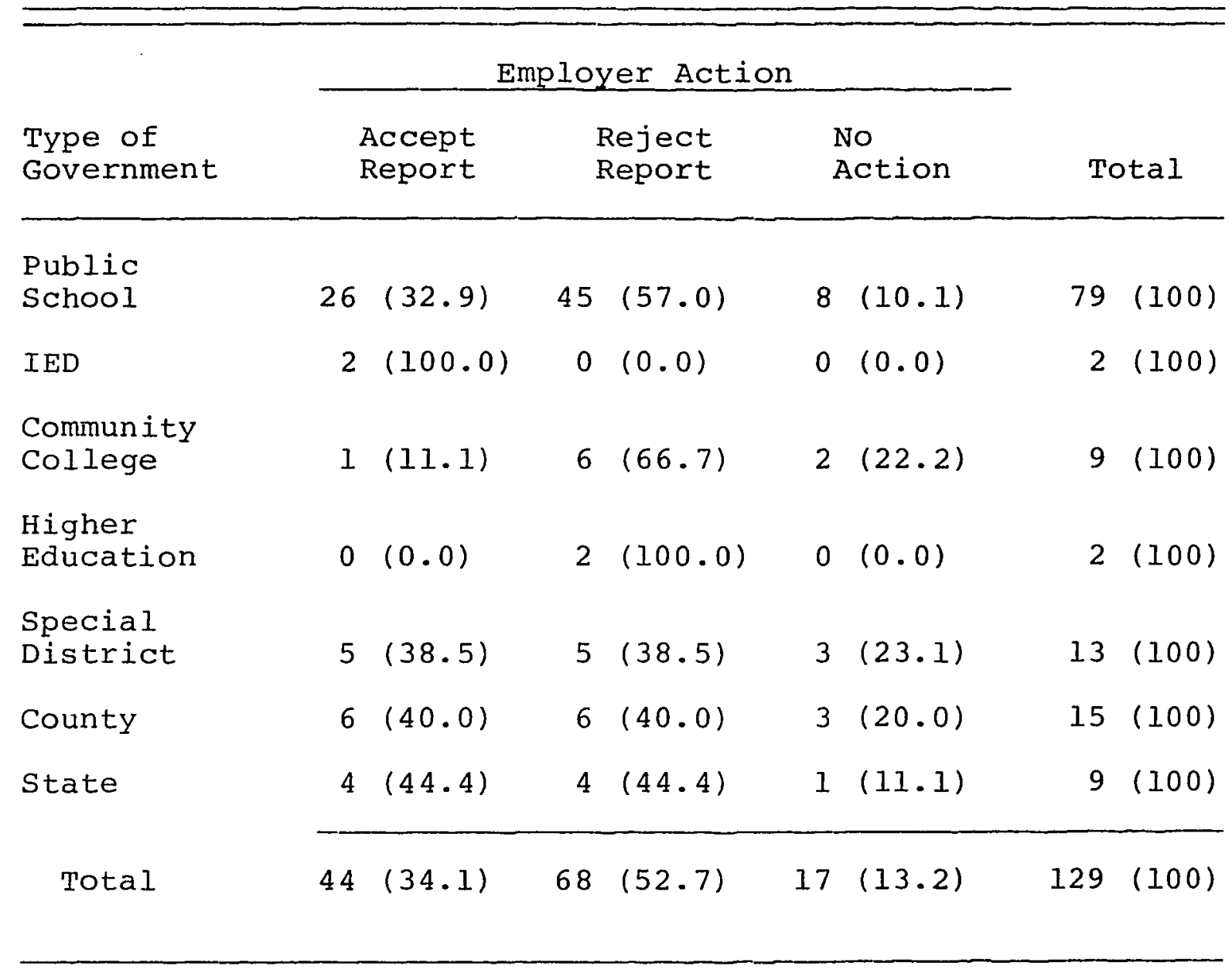

Lambda (asymmetric) $=.032$ with employer action dependent Missing observations $=2$ 
TABLE XXXIV

EMPLOYEE ORGANIZATION BY EMPLOYER ACTION ON OREGON FACT-FINDING REPORTS, 1974-1977

\begin{tabular}{|c|c|c|c|c|c|c|c|c|}
\hline \multirow{3}{*}{$\begin{array}{l}\text { Employee } \\
\text { Organization } \\
\text { OEA }\end{array}$} & \multicolumn{6}{|c|}{ Employer Action } & & \\
\hline & \multirow{2}{*}{\multicolumn{2}{|c|}{$\begin{array}{l}\begin{array}{c}\text { Accept } \\
\text { Report }\end{array} \\
25(31.3)\end{array}$}} & \multicolumn{2}{|c|}{$\begin{array}{l}\text { Reject } \\
\text { Report }\end{array}$} & \multicolumn{2}{|c|}{$\begin{array}{l}\text { No } \\
\text { Action }\end{array}$} & \multicolumn{2}{|c|}{ Total } \\
\hline & & & 46 & $(57.5)$ & 9 & $(11.3)$ & 80 & $(100)$ \\
\hline AFSCME & 10 & $(83.3)$ & 2 & $(16.7)$ & 0 & $(0.0)$ & 12 & $(100)$ \\
\hline $\begin{array}{l}\text { OSEA } \\
\text { (Education) }\end{array}$ & 0 & $(0.0)$ & 3 & $(75.0)$ & 1 & $(25.0)$ & 4 & $(100)$ \\
\hline $\begin{array}{l}\text { Other } \\
\text { Teachers }\end{array}$ & 0 & $(0.0)$ & 2 & $(100.0)$ & 0 & $(0.0)$ & 2 & $(100)$ \\
\hline Fire (IAFF) & 0 & $(0.0)$ & 1 & $(33.3)$ & 2 & $(66.7)$ & 3 & $(100)$ \\
\hline Police & 0 & $(0.0)$ & 1 & $(100.0)$ & 0 & $(0.0)$ & 1 & $(100)$ \\
\hline Sheriff & 0 & $(0.0)$ & 0 & $(0.0)$ & 3 & $(100.0)$ & 3 & $(100)$ \\
\hline I.L.W.U. & 3 & $(50.0)$ & 2 & $(33.3)$ & 1 & $(16.7)$ & 6 & $(100)$ \\
\hline ONA & 0 & $(0.0)$ & 1 & $(100.0)$ & 0 & $(0.0)$ & 1 & $(100)$ \\
\hline Other & 4 & $(33.3)$ & 8 & $(66.7)$ & 0 & $(0.0)$ & 12 & $(100)$ \\
\hline OSEA (State) & 2 & $(40.0)$ & 2 & $(40.0)$ & 1 & $(20.0)$ & 5 & $(100)$ \\
\hline Total & 44 & $(34.1)$ & 68 & $(52.7)$ & 17 & $(13.2)$ & 129 & $(100)$ \\
\hline
\end{tabular}

Lambda (asymmetric) $=0.21$ with employer action dependent Missing observations $=2$ 
traditionally unquestioned) power employers have had over non-teaching staff, and their staffs' relatively low socioeconomic status.

Second, employer action in the protective services resembles that of the employees. Employers did not accept any reports, which indicates that fact-finding (when the final step is compulsory arbitration) may be viewed as just another step in the process. In this case employers have, like employee organizations, everything to gain and nothing to lose by going to arbitration.

Third, employers dealing with cases involving AFSCME had a very high propensity to accept reports ( 83 percent) as did the special districts, dealing with the ILWU, with acceptance of 50 percent of the reports.

Fourth, the state has a 20 percent no action rate when dealing with the State Employees (OSEA-State), which is only exceeded by the no action rate among the protective services and public schools with respect to non-teaching staff.

It is concluded then that employers' actions on factfinder's reports are associated with the employee organization they are dealing with. Whether this is a result of tradition, personalities of the actors, or other variables is unknown and further research in this area might prove very useful. in understanding Oregon public employee labor relations.

Summary of Employee and Employer Actions. Employee groups accept fact-finding reports more often than employers 
(48 percent vs. 34 percent respectively). Employees reject less often than employers ( 24 vs. 53 percent), but have a higher no action record (28 percent vs. 13 percent respectively)

There is no apparent association between the parties' actions and the sector. There is an apparent association between the employee organization and employee action, with education and state employees having a higher acceptance rate than the ILWU and the protective services' unions. There is no apparent association between employer action and the type of government, however there is an association between employer action and the union which they deal with. In this case employers dealing with AFSCME and the ILWU have a higher propensity to accept than those dealing with other unions. Of particular concern is the high no action and rejection rate by both employees and employers in the protective service area, which indicate fact-finding may not be useful in these cases.

Other factors that may affect the parties' actions will be discussed in the next section.

OTHER FACTORS AFFECTING THE PARTIES' ACTIONS

Other factors were considered that may affect the employee and employer actions on fact-finders' reports. The variables considered are time, population and census type, and the fact-finder. 
Time

In oregon law, specific time lines have been established in order to insure that the fact-finding process proceeds in an uninterrupted manner and that proposed solutions are made without undue time lapses. Excessive time lapses are seen to cause frustration among parties which adds to the problems involved, and perhaps adversely affects the parties' decisions to accept or reject fact-finders' reports.

In this study two time phases were cross tabulated with the parties' actions. The two phases are: (1) the time lapse from the request for fact-finding to the hearing, and (2) the time lapse from the hearing to the issuance of the report. These two phases are viewed as one measurement of the efficiency of the fact-finding process.

Request to Hearing. This time lapse is viewed as a measurement of the responsiveness and efficiency of the selection/scheduling process that is administered by the State Conciliation Service. Because the selection of a fact-finder involves the parties, it is expected that this lapse will take longer than if the ERB selected the factfinder without the parties' involvement.

The selection/scheduling phase was broken down into four categories. Table XXXV shows that this process has an almost even distribution, with 21 percent of the cases in the less than 4 week category, 32 percent in the 4 to 6 week category, 25 percent in the 6 to 8 week category, and 22 percent: in the over 8 week category. 
TABLE XXXV

FREQUENCY DISTRIBUTION OF TIME PHASE 1 REQUEST TO HEARING AND TIME PHASE 2 HEARING TO REPORT

\begin{tabular}{|c|c|c|c|c|c|c|c|c|}
\hline & & \multicolumn{5}{|c|}{ Time Categories } & \multirow[b]{2}{*}{ Missing } & \multirow[b]{2}{*}{ Total } \\
\hline & & $\begin{array}{l}\text { Less than } \\
4 \text { weeks }\end{array}$ & $4-6$ & weeks & 6-8 weeks & $\begin{array}{l}\text { Over } \\
8 \text { weeks }\end{array}$ & & \\
\hline $\begin{array}{l}\text { Time Phase } \\
\text { Request to }\end{array}$ & $\begin{array}{l}1 \\
\text { Hearing }\end{array}$ & $24 \quad(21.1)$ & 36 & $(31.6)$ & $(25.4)$ & $(21.9)$ & 17 & 131 \\
\hline $\begin{array}{l}\text { Time Phase } \\
\text { Hearing to }\end{array}$ & $\begin{array}{l}2 \\
\text { Report }\end{array}$ & $44(38.6)$ & 46 & $(40.4)$ & $(12.3)$ & $10(8.8)$ & 17 & 131 \\
\hline
\end{tabular}

Missing observations $=17$, all percents adjusted for missing data 
Considering the amount of time involved in mailing, it seems reasonable that this phase mj.ght take as long as one month to accomplish, and 21 percent of the cases did take that long. However 79 percent of the cases took over one month, and of those, 22 percent took over two months from the request for fact-finding and a hearing. In comparison, Michigan's average number of days between the fact-finders' appointment and the hearing was 39 days (up from 17 days in the 60's when parties did not select the fact-finder). 26 There are reasons for Oregon's performance. First, because fact-finders in Oregon do not work for the state Conciliation Service, they are not always as flexible in scheduling their time to respond immediately to parties requesting their services; second, good fact-finders (in the parties' views) are scarce, and many of the factfinders cannot respond quickly due to other commitments involving their fact-finding expertise. It is concluded then, that because oregon is faced with a shortage of competent fact-finders, the selection/scheduling process takes longer than is desirable.

Hearing to Report. This time phase refers to the time lapse between the hearing and issuance of the fact-finders' report. This measures the efficiency of the fact-finders, that is, how responsive the fact-finders are to the requirements that a report be issued within one month of the hearing. 
Table XXXV shows that in 39 percent of the cases, reports were issued in less than four weeks of the hearing, and thus within the proscribed period by the legislature. This table also shows that in 40 percent of the cases $4-6$ weeks lapsed, in 12 percent of the cases 6-8 weeks, and in 9 percent over two months lapsed between the hearing and the issuance of the fact-finder's report.

This means that over 61 percent of the fact-finder's reports took longer than the proscribed one month for a report to be issued. 27 Reasons for this include several factors: (1) in some cases post-hearing briefs are filed that extend the process as much as two weeks, (2) the aforementioned shortage of fact-finders which causes an overload on some fact-finders, and (3) some fact-finders are inordinately slow and unresponsive to the intent of the law and the parties' needs. This study will make recommendations as how to reduce this time lapse in the concluding chapter.

Time and Parties' Actions. The relationship or association between time and the parties' actions (that is, their propensity to accept or reject fact-finders' reports) was considered. Tables XXXVI and XXXVII show there appears to be no association between the time and parties' action as lambda was zero in both cases. However, this does not mean that time has no impact on parties' actions. There is reason to suspect that abnormally high time lapses may affect parties' attitudes, which in turn may affect the parties' 
TABLE XXXVI

TIME LAPSE REQUEST TO HEARING AND HEARING TO REPORT BY EMPLOYEE ACTION ON OREGON

FACT-FINDING REPORTS, 1974-1977

\begin{tabular}{|c|c|c|c|c|}
\hline \multirow[b]{2}{*}{$\begin{array}{l}\text { Time } \\
\text { Category }\end{array}$} & Time Phase & 1 - Request & to Hearing & \multirow[b]{2}{*}{ Total } \\
\hline & $\begin{array}{l}\text { Accept } \\
\text { Report }\end{array}$ & $\begin{array}{l}\text { Reject } \\
\text { Report }\end{array}$ & $\begin{array}{l}\text { No } \\
\text { Action }\end{array}$ & \\
\hline $\begin{array}{l}\text { Less than } \\
4 \text { weeks }\end{array}$ & $9(37.5)$ & $8(33.3)$ & $7(29.2)$ & $24(100)$ \\
\hline 4 to 6 weeks & $15 \quad(41.7)$ & $10(27.8)$ & $11(30.6)$ & $36(100)$ \\
\hline 6 to 8 weeks & $18(62.1)$ & $6(20.7)$ & $5(17.2)$ & $29(100)$ \\
\hline Over 8 weeks & $10(40.0)$ & $7(28.0)$ & $8(32.0)$ & $25(100)$ \\
\hline Total & $52(45.6)$ & $31 \quad(27.2)$ & $31(27.2)$ & $114(100)$ \\
\hline \multicolumn{2}{|c|}{$\begin{array}{l}\text { Lambda (asymmetric) }=0.00 \\
\text { Goodman-Kruskal tau }=.023\end{array}$} & \multirow{2}{*}{\multicolumn{2}{|c|}{$\begin{array}{l}\text { with employee action } \\
\text { with employee action } \\
2-\text { Hearing to Report }\end{array}$}} & $\begin{array}{l}\text { dependent } \\
\text { dependent }\end{array}$ \\
\hline \multirow[b]{2}{*}{$\begin{array}{l}\text { Time } \\
\text { Category }\end{array}$} & Time Phase & & & \multirow[b]{2}{*}{ Total } \\
\hline & $\begin{array}{l}\text { Accept } \\
\text { Report }\end{array}$ & $\begin{array}{l}\text { Reject } \\
\text { Report }\end{array}$ & $\begin{array}{l}\text { No } \\
\text { Action }\end{array}$ & \\
\hline $\begin{array}{l}\text { Less than } \\
4 \text { weeks }\end{array}$ & $20(45.5)$ & $11(25.0)$ & $13(29.5)$ & $44(100)$ \\
\hline 4 to 6 weeks & $22(47.8)$ & $12(26.1)$ & $12(26.1)$ & $46(100)$ \\
\hline 6 to 8 weeks & $5(35.7)$ & $5(35.7)$ & $4(28.6)$ & $14(100)$ \\
\hline \multirow[t]{2}{*}{ Over 8 weeks } & $6(60.0)$ & $2(20.0)$ & $2(20.0)$ & $10(100)$ \\
\hline & $53(46.5)$ & $30(26.3)$ & $31(27.2)$ & $114(100)$ \\
\hline $\begin{array}{l}\text { Lambda (asymm } \\
\text { Goodman-Krusk } \\
\text { Missing obser }\end{array}$ & $\begin{aligned}(i c) & =0.00 \\
\text { tau } & =.008 \\
\text { tions } & =17\end{aligned}$ & $\begin{array}{l}\text { with employ } \\
\text { with employ }\end{array}$ & $\begin{array}{l}\text { yee action } \\
\text { yee action }\end{array}$ & $\begin{array}{l}\text { dependent } \\
\text { dependent }\end{array}$ \\
\hline
\end{tabular}


TABLE XXXVII

TIME LAPSE REQUEST TO HEARING AND HEARING TO REPORT BY EMPLOYER ACTION ON OREGON

FACT-FINDING REPORTS, 1974-1977

\begin{tabular}{|c|c|c|c|c|}
\hline \multirow[b]{2}{*}{$\begin{array}{l}\text { Time } \\
\text { Category }\end{array}$} & Time Phase & 1 - Request & to Hearing & \multirow[b]{2}{*}{ Total } \\
\hline & $\begin{array}{l}\text { Accept } \\
\text { Report }\end{array}$ & $\begin{array}{l}\text { Reject } \\
\text { Report }\end{array}$ & $\begin{array}{l}\text { No } \\
\text { Action }\end{array}$ & \\
\hline $\begin{array}{l}\text { Less than } \\
4 \text { weeks }\end{array}$ & $7(29.2)$ & $12(50.0)$ & $5(20.8)$ & $24(100)$ \\
\hline 4 to 6 weeks & $15(41.7)$ & $17(47.2)$ & $4(11.1)$ & $36(100)$ \\
\hline 6 to 8 weeks & $7(24.1)$ & $19(65.5)$ & $3(10.3)$ & $29(100)$ \\
\hline Over 8 weeks & $9(36.0)$ & $14(56.0)$ & $2(8.0)$ & $25(100)$ \\
\hline Total & $38 \quad(33.3)$ & $62(54.4)$ & $14(12.3)$ & $114(100)$ \\
\hline \multicolumn{2}{|c|}{$\begin{array}{l}\text { Lambda (asymmetric) }=0.00 \\
\text { Goodman-Kruskal tau }=.021\end{array}$} & \multicolumn{3}{|c|}{$\begin{array}{l}\text { with employer action dependent } \\
\text { with employer action dependent }\end{array}$} \\
\hline \multirow[b]{2}{*}{$\begin{array}{l}\text { Time } \\
\text { Category }\end{array}$} & Time Phase & 2 - Hearing & to Report & \multirow[b]{2}{*}{ Total } \\
\hline & $\begin{array}{l}\text { Accept } \\
\text { Report }\end{array}$ & $\begin{array}{l}\text { Reject } \\
\text { Report }\end{array}$ & $\begin{array}{l}\text { No } \\
\text { Action }\end{array}$ & \\
\hline $\begin{array}{l}\text { Less than } \\
4 \text { weeks }\end{array}$ & $14(31.8)$ & $21 \quad(47.7)$ & $9(20.5)$ & $44 \quad(100)$ \\
\hline 4 to 6 weeks & $16(34.8)$ & $28 \quad(60.9)$ & $2(4.3)$ & $46(40.4)$ \\
\hline 6 to 8 weeks & $4(28.6)$ & $9(64.3)$ & $1(7.1)$ & $14(12.3)$ \\
\hline Over 8 weeks & $4(40.0)$ & $5(50.0)$ & $1(10.0)$ & $10(8.8)$ \\
\hline Total & $38(33.3)$ & $63(55.3)$ & $13(11.4)$ & $114(100)$ \\
\hline
\end{tabular}

Lambda (asymmetric) $=0.00$ Goodman-Kruskal tau $=.018$ Missing observations $=17$ with employer action dependent with employer action dependent 
actions. Although this study did not include attitudes as a variable, it is an area which future research could be directed. In the meantime the rationale for making recommendations that would reduce the time involved in the factfinding process is two-fold: (1) compliance of the law (and its intent) and (2) the possible adverse effects time has on parties' attitudes toward the process.

Population and Census Type

Table XXXVIII shows data relating fact-finding to population and census type. It reveals that requests for fact-finding were fairly evenly distributed between small, medium, and large cities; however, in low populated areas the percent of requests was about half that of the cities of all sizes. This is not surprising as most public services are in cities, and therefore most unions' bargaining units and the need for fact-finding.

Table XXXVIII also shows the vast majority $(74.4$ percent) of the requests for fact-finding were from urban areas (which includes all cities over 2,500 not classified as suburban). The percent of cases in the rural and suburbain areas are essentially the same with 13.7 percent and 12.0 percent respectively. Again this makes sense when one considers where public services are demanded and therefore located.

Population, Census Type and Parties' Actions. Cross tabulation tables are provided that relate employee and 
TABLE XXXVIII

OREGON FACT-FINDING REQUESTS BY POPULATION CATEGORY AND CENSUS TYPE, 1974-1977

\begin{tabular}{cc}
\hline Population Category & $\begin{array}{c}\text { Adjusted Frequency } \\
\text { (percent) }\end{array}$ \\
\hline Under 2,500 & 12.8 \\
$2,500-10,000$ & 20.5 \\
$10,000-50,000$ & 36.8 \\
Over 50,000 & 29.9 \\
Total & 100.00 \\
Census Type & Adjusted Frequency \\
(percent) \\
Rural
\end{tabular}

Missing observations $=14$ 
action with population categories and census type. These tables are used to determine the effect, if any, the population and type of area may have on parties' actions.

Table XXXIX shows there appears to be a mild statistical association between population and employee action $($ lambda $=.07)$. The high acceptance rate by employees in less populated areas may be an indication of their lack of strength and bargaining power, and thus their willingness to accept the fact-finders' report, rather than go on to strike. Furthermore, the under 2,500 category has a no action rate of 33 percent which (like the 2,500 to 10,000 category) is an indication of the lower populated areas reluctance to reject reports. Of interest is the high (60.5 percent) employees acceptance rate in the 10,000 to 50,000 category.

Table XXXIX also shows there is no significant statistical relationship between employee action and census type, although differences exist. For example, suburban employee groups accepted fact-finding reports in 64 percent of their cases, where urban employee groups accepted in 44 percent of their cases.

Employer data is reflected in Table Xxxx. This table shows that although there is no statistical association between employer action and population and census type, some interesting patterns exist. There is a higher propensity for highly population areas $(10,000$ and over) to accept reports than in the rural areas (under 2,500) and small towns $(2,500-10,000)$. When comparing the census types, mild 
TÄBLE XXXIX

POPULATION AND CENSUS TYPE BY EMPLOYEE ACTION ON OREGON FAC'T-FINDING REPORTS, 1974-1977

\begin{tabular}{|c|c|c|c|c|}
\hline \multirow[b]{2}{*}{$\begin{array}{l}\text { Population } \\
\text { Category }\end{array}$} & \multicolumn{3}{|c|}{ Employee Action } & \multirow[b]{2}{*}{ Total } \\
\hline & $\begin{array}{l}\text { Accept } \\
\text { Report }\end{array}$ & $\begin{array}{l}\text { Reject } \\
\text { Report }\end{array}$ & $\begin{array}{l}\text { No } \\
\text { Action }\end{array}$ & \\
\hline Under 2,500 & $8(53.3)$ & $2(13.3)$ & $5(33.3)$ & $15(100)$ \\
\hline $2,500-10,000$ & $7(29.2)$ & $7(29.2)$ & $10(41.7)$ & $24(100)$ \\
\hline $10,000-50.000$ & $26(60.5)$ & $6(14.0)$ & $11(25.6)$ & $43(100)$ \\
\hline Over 50,000 & $14(41.2)$ & $15(44.1)$ & $5(14.7)$ & $34(100)$ \\
\hline Total & $55(47.4)$ & $30 \quad(25.9)$ & $31(26.7)$ & $116(100)$ \\
\hline \multicolumn{5}{|c|}{ Lambda (asymmetric) $=.065$ with employee action dependent } \\
\hline Rural & $8(50.0)$ & $2(12.5)$ & $6(37.5)$ & $16(100)$ \\
\hline Suburban & $9(64.3)$ & $3(21.4)$ & $2(14.3)$ & $14(100)$ \\
\hline Urban & $38(44.2)$ & $25(29.1)$ & $23(26.7)$ & $86(100)$ \\
\hline Total & $55(47.4)$ & $30(25.9)$ & $31 \quad(26.7)$ & $116(100)$ \\
\hline
\end{tabular}

Lambda (asymmetric) $=.00$ with employee action dependent Goodman-Kruskal tau $=.018$ with employee action dependent Missing observations $=15$ 
TABLE XXXX

POPULATION AND CENSUS TYPE BY EMPLOYER ACTION ON OREGON FACT-FINDING REPORTS, 1974-1977

\begin{tabular}{lcccccc}
\hline & \multicolumn{4}{c}{ Employer Action } \\
\cline { 2 - 6 } $\begin{array}{l}\text { Population } \\
\text { Category }\end{array}$ & $\begin{array}{c}\text { Accept } \\
\text { Report }\end{array}$ & $\begin{array}{l}\text { Reject } \\
\text { Report }\end{array}$ & $\begin{array}{l}\text { No } \\
\text { Action }\end{array}$ & Total \\
\hline Under 2,500 & $4(26.7)$ & 9 & $(60.0)$ & 2 & $(13.3)$ & $15(100)$ \\
$2,500-10,000$ & $4(16.7)$ & 16 & $(66.7)$ & 4 & $(16.7)$ & $24(100)$ \\
$10,000-50,000$ & $17(39.5)$ & 22 & $(51.2)$ & 4 & $(9.3)$ & $43(100)$ \\
Over 50,000 & $14(41.2)$ & 14 & $(41.2)$ & 6 & $(17.6)$ & $34(100)$ \\
\cline { 2 - 6 } Total & $39(33.6)$ & 61 & $(52.6)$ & $16(13.8)$ & $116(100)$
\end{tabular}

Lambda (asymmetric) $=0.00$ with employer action dependent Goodman-Kruskal tau $=.034$ with employer action dependent

Census Type

\begin{tabular}{|c|c|c|c|c|c|c|c|c|}
\hline Rural & 4 & $(25.0)$ & 9 & $(56.3)$ & 3 & $(18.8)$ & 16 & $(100)$ \\
\hline Suburban & 8 & $(57.1)$ & 4 & $(28.6)$ & 2 & $(14.3)$ & 14 & $(100)$ \\
\hline Urban & 27 & $(31.4)$ & 48 & $(55.8)$ & 11 & $(12.8)$ & 86 & $(100)$ \\
\hline Total & 39 & $(33.6)$ & 61 & $(52.6)$ & 16 & $(13.8)$ & 116 & $(100)$ \\
\hline
\end{tabular}

Lambda (asymmetric) $=.073$ with employer action dependent Missing observations $=15$ 
association exists (lambda $=.07$ ) and it is observed that suburban areas have an acceptance rate 32 points higher than rural areas, and 26 points higher than urban areas. This may be due to the fact that rural and urban areas (core city) do not have the population and business influx that give the suburban areas a better financial base from which to work.

In summary, 74 percent of the requests for fact-finding originate from urban areas. Although mild association exists between employee action and population, and employer action and census type, this author is reluctant to make much of these differences as they are somewhat inconsistent and may be due to other factors.

\section{The Fact-Finders}

In order to ascertain the impact individual factfinders have on the parties' action a cross tabulation was made between the two variables. The results showed the highest statistical association in this study. Because of confidentiality considerations the fact-finder names and employee/employer actions will not be presented. However, the following general comments are appropriate.

First, there is an association between the employee actions and the fact-finder as the cross tabulation resulted in a lambda $=.22$ (a moderate association).

Second, there is an equally strong association (lambda $=.22$ ) between employer action and the fact-finder involved. 
These associations are not surprising given the comments of the parties during the interviews. Many parties indicated they had more faith and respect in and for some fact-finders than others (although names were never solicited or volunteered). Further discussion about factfinders will occur in the next chapter, and recommendation on how to improve their effectiveness made in the concluding chapter. In the meantime there is evidence that the parties' action are associated with the individual factfinder's personality and perceived competency.

\section{SUMMARY OF AGGREGATE DATA}

The aggregate data in Table XVI supports one intent of Oregon's impasse resolution procedure; that each step significantly reduces the number of impasses and therefore the number of potential strikes. The fact-finding phase accomplishes this also. Over 31 percent of the cases were resolved prior to hearing, which supports the concept that the cost and inconvenience of fact-finding discourages its use. of the cases going to hearing, few reports were accepted; and most of the cases were settled in super-mediation, but prior to strike.

Table XXXXI shows a summary of the fact-finding data generated in this dissertation. It shows that the greatest use of the fact-finding process occurs in the education sector and in particular with public schools and involves the OEA which represents $(\mathrm{K}-12)$ teachers. Cases most often 
TABLE XXXXI

SUMMARY OF FACT-FINDING DATA

\begin{tabular}{|c|c|c|}
\hline Phase & Unit & $\begin{array}{l}\text { Unit With Highest } \\
\text { Percent of Cases }\end{array}$ \\
\hline Requests & $\begin{array}{l}\text { Sector } \\
\text { Employee Group } \\
\text { Gov't Employer }\end{array}$ & $\begin{array}{l}\text { Education - } 69 \\
\text { OEA - } 57 \\
\text { Public Schools - } 58\end{array}$ \\
\hline $\begin{array}{l}\text { Settled } \\
\text { Before } \\
\text { Hearing }\end{array}$ & $\begin{array}{l}\text { Employee Group } \\
\text { Gov't Employer }\end{array}$ & $\begin{array}{l}\text { OSEA (Ed.) }-64, \\
\text { AFSCME }-48 \\
\text { Higher Ed }-50, \text { County }-48 \\
\text { State }-41\end{array}$ \\
\hline \multicolumn{3}{|c|}{ Parties' Actions } \\
\hline $\begin{array}{l}\text { Accept } \\
\text { Report }\end{array}$ & $\begin{array}{l}\text { Employee Group* } \\
\text { Gov't Employer* }\end{array}$ & $\begin{array}{l}\text { OEA - 51, AFSCME - } 42 \\
\text { State }-44, \text { County }-40\end{array}$ \\
\hline $\begin{array}{l}\text { Reject } \\
\text { Report }\end{array}$ & $\begin{array}{l}\text { Employee Group* } \\
\text { Gov't Employer* }\end{array}$ & $\begin{array}{l}\text { AFSCME - 50, ILWU - 50 } \\
\text { Community College }-67 \\
\text { Public Schools }-57\end{array}$ \\
\hline $\begin{array}{l}\text { No } \\
\text { Action }\end{array}$ & $\begin{array}{l}\text { Employee Group } \\
\text { Gov't Employer }\end{array}$ & $\begin{array}{l}\text { Fire and Sheriff }-67 \\
\text { Those dealing } \mathrm{w} / \mathrm{Fire} \text { and } \\
\text { Sheriff }-67 \text { and } 100 \\
\text { respectively }\end{array}$ \\
\hline *Others & re higher but only & 1 or 2 cases \\
\hline
\end{tabular}

Strongest Statistical Associations

\begin{tabular}{|c|c|c|c|}
\hline Independent Variable & & Dependent Variable & $\begin{array}{c}\text { Lambda } \\
\text { (Asymmetric) }\end{array}$ \\
\hline Employee Organization & by & Employee Action & 0.104 \\
\hline Type of Government & by & Employee Action & 0.059 \\
\hline Employee Organization & by & Employer Action & 0.210 \\
\hline Population Category & by & Employee Action & 0.066 \\
\hline Census Type & by & Employer Action & 0.073 \\
\hline Fact-Finder & by & Employee Action & 0.22 \\
\hline Fact-Finder & by & Employer Action & 0.22 \\
\hline
\end{tabular}


settled before hearing involved the OSEA (education) and AFSCME employee groups, and the governmental types of higher education, county, and the state.

Fact-finding reports were most often accepted by the OEA and the state government. The highest rejection rate involved AFSCME, the ILWU and the governmental units of community colleges and public schools. The no action was highest among employees and employers in the protective services.

There appears to be a mild statistical relationship between employee actions and the employee organization and type of government involved. Employer actions have a moderate statistical relationship with the employee group they are dealing with.

Although time has little statistical association with parties' actions the author is reluctant to dismiss tris as unimportant. Population and census type data reveal that the vast majority of cases occur in urban areas, however, association between this and parties' actions is mixed and inclusive.

of particular significance is the statistical association between both parties' actions and the fact-finder. This aggregate data reveals much information about the characteristics of the fact-finding phase of Oregon's impasse resolution process. In order to further ascertain the effectiveness of fact-finding, the views of the parties were considered. These views are explained and analyzed in the next two chapters. 
CHAPTER IV NOTES

${ }^{1}$ oregon Revised Statutes, secs. 243.712 (1) and 662 . 405-. 455 (1977).

2 This is considered by most labor relations experts as more desirable than part-time, non professional mediators.

${ }^{3}$ oregon Revised Statutes, sec. 243.712 (2b) (1977).

${ }^{4}$ ors $243.712(2 c)$. This option is rarely used.

${ }^{5}$ Oregon Revised Statutes, sec. 243.722 (1-2) (1977).

${ }^{6}$ ORS 243.722 .

${ }^{7}$ Oregon State Conciliation Service Rules, 15-015.

${ }^{8}$ Nationally there is much debate on this issue. In oregon the role is judicial unless both parties request otherwise.

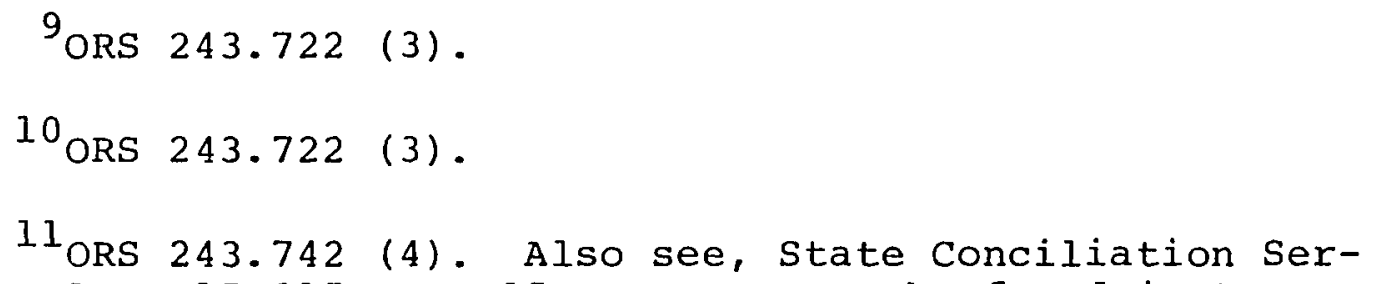
vice Rules, 15-015, No. 15. A copy may be found ir Appendix D.

${ }^{12}$ ORS 243.722 ( 3 and 5 ).

${ }^{13}$ Oregon Revised Statutes, sec. 243.726 (a-d) (1977).

${ }^{14}$ ORS 243.726 (3a).

${ }^{15}$ Oregon Revised Statutes, sec. 243.746 ( 1 and 2) (1977). 
${ }^{16}$ ORS $243.746 \quad(4)$.

17 ORS 243.762 .

18 Foundation for Oregon Research and Education, Collective Bargaining and Tenure in Oregon Education (Portland, Ore.: Foundation for Oregon Research and Education, 1977), p. 51. Also see Oregon Legislative Assembly, 1979, Senate Bill 331.

${ }^{19}$ The strength of the values of lambda (asymmetric), which is a PRE measure, were interpreted by using the following scale: 60t: strong, 40-60: moderately strong, 20-40: moderate, 0-20: mild, and 0: none. GoodmanKruskal's tau (also a PRE measure) was computed when lambda $=0$. This is because lambda, at times, had the property of taking on a value of zero when there may be a weak correlation. See Huburt M. Blalock, Jr., Social Statistics, 2nd ed. (New York: McGraw, 1972), pp. 302-303. The existence of a strong or weak statistical correlation does not prove that one variable causes or doesn't cause another, rather it gives signals as to the direction of possible future research. Also future analysis of a longer time period may yield different results than the four year period covered in this study.

20 There were 26 of the 239 cases (or about 10 percent) that involved home rule cities and counties.

${ }^{21}$ John E. Drothing, and David E. Lipsky, "The Outcome of Impasse Prccedures in New York Schools Under the Taylor Law," The Arbitration Journal, 26 (1971), 91-92.

22 Jack Steiber and Benjamin Wolkinson, "Fact-Finding Viewed by Fact-Finders: The Michigan Experience," Labor Law Journal, 28, No. 2 (1977), 94.

23 Drothing and Lipsky, pp. 91-92.

24 Byron Yaffe, and Howard Goldblatt, Fact-Finding in Public Employment Disputes in New York State: More Promise than Illusion (Ithaca: School of Industrial Relations, Cornell Univ., 1971), p. 31.

${ }^{25}$ Yaffe and Goldblatt, p. 18. Also see Steiber and Wolkinson, p. 92. 
${ }^{26}$ Steiber and Wolkinson, p. 93.

27 By way of comparison, in Michigan the average is 30 days. See Steiber and Wolkinson, p. 93. 
CHAPTER VI

VIEWS OF THE NEUTRALS

In order to further ascertain the nature and effectiveness of fact-finding, the views of those involved in the process were solicited. This chapter covers the views of the mediators and fact-finders. The vehicle used to translate their views into written form was a questionnaire. The items were designed to elicit responses to pertinent questions about the fact-finding process. Many of the items resemble the types of questions asked in studies done in other states, and comparative information will be provided where appropriate. ${ }^{1}$ The format of the questionnaires may be found in Appendix B.

The questionnaire was administered during a personal interview situation, in order to provide more candor and a higher response rate than a mail or phone interview might. Furthermore, the interview was seen as a way to gain insight into the fact-finding process that the aggregate statistics and methods could not provide.

The sampling technique employed in the interview schedule was non-random because the universe of cases was the topic of the study. Furthermore, not all persons and/or categories of experts are equally experienced and important; and indeed, some have more insight into the process and much 
more impact on policy-formation than others. ${ }^{2}$ For further methodological details see Appendix A. The number of participants interviewed from each subsample of mediators and fact-finders are as follows:

(1) Mediators -- nine were interviewed; these nine account for about 90 percent of all non-home rule fact-finding cases requiring post-factfinding mediation. A list of those mediators interviewed is provided in Appendix B.

(2) Fact-finders -- ten were interviewed; these ten account for over 64 percent of the non-home rule fact-finding cases going to hearing. A list of those fact-finders interviewed is provided in Appendix B.

Both mediators' and fact-finders' views are discussed separately in the following order: first, the mediators; and second, the fact-finders.

\section{VIEWS OF THE MEDIATORS}

Mediators in Oregon are full-time employees of the State Conciliation Service. Of the nine interviewed all but one were men. Their educational background is as follows: 1 attorney, 2 with Bachelors Degrees, 2 with Masters Degrees, and 2 with Doctorate Degrees. All have some college. They all have had practical experience in labor relations, some in the public sector, and some in the private sector. ${ }^{3}$ over two thirds of the mediators interviewed were 
involved in both pre-fact-finding and post-fact-finding mediation (super-mediation). Because of this experience they are able to evaluate the impact of fact-finding from a unique position.

\section{Reasons for Fact-Finding}

The mediators were asked to rank the five most important reasons that cause fact-finding. The reasons should not be confused with the issues, which are the items to be settled. Although no one mediator came up with five reasons, their rankings did fall into seven basic categories: (1) inexperience, (2) face-saving, (3) demonstration of determination, (4) personal venting of feelings, (5) hold out and delay tactics, (6) outside pressure, and (7) hard bargaining. Each of these: is discussed in detail as follows:

(1) Inexperience. This was ranked by mediators as the most important cause of fact-finding. It refers to the parties' lack of expertise in bargaining and inability to strike a bargain. Inexperience also refers to the parties' lack of understanding or sympathy with the philosophy of the collective bargaining process and its purpose. It is partially responsible for the large number of issues going to fact-finding. Given the newness of the law, it seems reasonable to expect a period where both parties adjust to their new relationship and learn by experience. 
Several mediators mentioned that inexperience is a particular problem in the education sector, where the idealism of the teachers and the authoritarian and paternalistic background of school boards have clashed. It was suggested that as both parties learn more about the collective bargaining process, inexperience will be less of a cause of fact-finding. This might be a topic for future research.

(2) Face-saving. This was ranked by mediators as the second highest cause of fact-finding. It refers to the inability of the parties' representatives to compromise because of their constituents' firm positions on a particular issue or issues. Fact-finding provides a neutral's view and recommendations, which are utilized as a rationale to settle or strike a bargain. The fact-finder in this case becomes the "scape goat" or the "per-diem fall guy," as the representative of each party can blame the fact-finder for the resulting compromise.

This author views this cause as a positive sign that shows that in oregon fact-finding does provide an avenue for compromise that allows the parties to save face. This role is particularly important during the adjustment phase of collective bargaining where the bitterness of a loss of power by one party and the eagerness of a newly gained power by the other party are both soothed.

(3) Demonstration of Determination. Mediators ranked this as the third highest cause of fact-finding. This refers to the propensity of the parties' representatives to 
demonstrate to their constituents that they are working their hardest to represent the parties' interest. By not compromising prior to fact-finding, some negotiators feel that the employers or employee group will have clear evidence of the negotiators' firmness and commitment to the parties' goals. Of course, once the fact-finders' report is issued, they then have a "scape goat" for further compromise (as do the parties themselves).

(4) Personal Venting of Feelings. Mediators ranked this fourth, but very close to the previously discussed cause. This refers to a tendency of some negotiations to be marred by personal vendettas or unpleasant past relationships between certain participants of each party. Evidently this does not just apply to the parties, but occasionally applies to the professional representatives (who ironically enough are hired because of their expertise and objective$i t y)$.

Again fact-finding serves a positive function that the aggregate statistics cannot show, that being a stage or forum for the parties to vent their feelings to their groups and the public in a controlled environment. Such a forum is of great help in allowing the actors to have their say, which is seen equally as important as any recommendations that result from the fact-finders' report.

(5) Holdout or Delay Tactics. This ranked close to number four and refers to some parties' tendency to use fact-finding as a tactic to stall or holdout offers that 
might result in a settlement. The thought by management is that they have everything to gain and nothing to lose by going to fact-finding, as they know their bottom line, and perhaps the fact-finder will recommend something less than that. Some unions on the other hand, may have not been able to secure what they want and hope the fact-finder may recommend something above what the employer offered. In both cases, the parties hope to use the fact-finders' report as an instrument of pressure against the other party in order to gain more favorable terms.

Furthermore, fact-finding is used as a way of securing a time schedule as part of a strategy based upon budget deadlines or strike effectiveness. For example, a teachers' union may want to strike and use the required fact-finding process as a convenient way to pass the time during summer, thus ending fact-finding and instituting strike in september when school is in and strike is more meaningful. More specific questions relating to this will be covered later in this chapter.

(6) Outside Pressure. This was not mentioned too often but warrants brief discussion. Some mediators feel that the state level of the union or employer groups indirectly (or directly) put pressure on the parties to negotiate an "ideal" contract. Associated with this is the tendency toward idealism by both the rank and file, and the employers. This idealism leads them to expect that an "ideal" contract can be achieved in short order. Thus, 
both parties have been known to be very inflexible at the bargaining table because they expect, or are expected, to secure a contract that a central body such as the oregon School Boards Association (OSBA) or the Oregon Education Association (OEA) suggests is desirable. Although it is difficult to determine the extent of such pressure, it is perceived as important by some experienced mediators as a reason for fact-finding.

(7) Hard Bargaining. As a category this ranked last, but very close to number 5 and 6 . As perceived by the mediators, some parties go to fact-finding because they have reached an impasse due to their differences in what they perceive as their final bargaining position. Again, factfinding provides a cooling-off period that gives the parties time to re-evaluate their positions and gives a neutral's view of what is reasonable and fair, thus increasing the chances of settlement without strike.

In summary, the mediators essentially attributed the cause of fact-finding to seven reasons. These reasons are interrelated, and for one to suggest one or two are the cause of fact-finding would be misleading. The interviews demonstrate what we already know: that the causes of impasse are very complex and vary from case to case. It further indicates that fact-finding is a process that has the potential to accommodate a variety of party needs. Further information from the questionnaires will reveal this fact. 
The Effectiveness of Fact-Finding

In order to obtain the mediators' views as to the effectiveness of fact-finding in oregon, eleven questions were asked. These questions and the mediators' responses are shown in Table xxxxII. Each question will be discussed along with additional comments obtained in the interview.

(1) The Parties Generally Bargain in Good Faith Through Mediation and Fact-Finding. A sizeable majority of the mediators thought parties do generally bargain in good faith through mediation and fact-finding. Although 78 percent of their responses to item one were in the agree portion of the scale, they almost uniformly made comments such as "what is good faith," or "do you mean technically good faith or reasonable good faith?" In several instances mediators said most parties do bargain in good faith, but some consistently do not bargain in good faith. There was general agreement that time and experience on the part of the parties might produce an atmosphere where the intent as well as the legal requirements for good faith bargaining will occur with increased frequency and consistency. The reasoning is that familiarity with bargaining contributes to the socialization of the parties to the process. This internalizing of the intellectual basis of the process leads to more effective bargaining; fact-finding is seen as contributing to this socialization.

(2) Fact-Finding Significantly Reduces Issues Causing Impasse. The majority of the mediators thought that fact- 


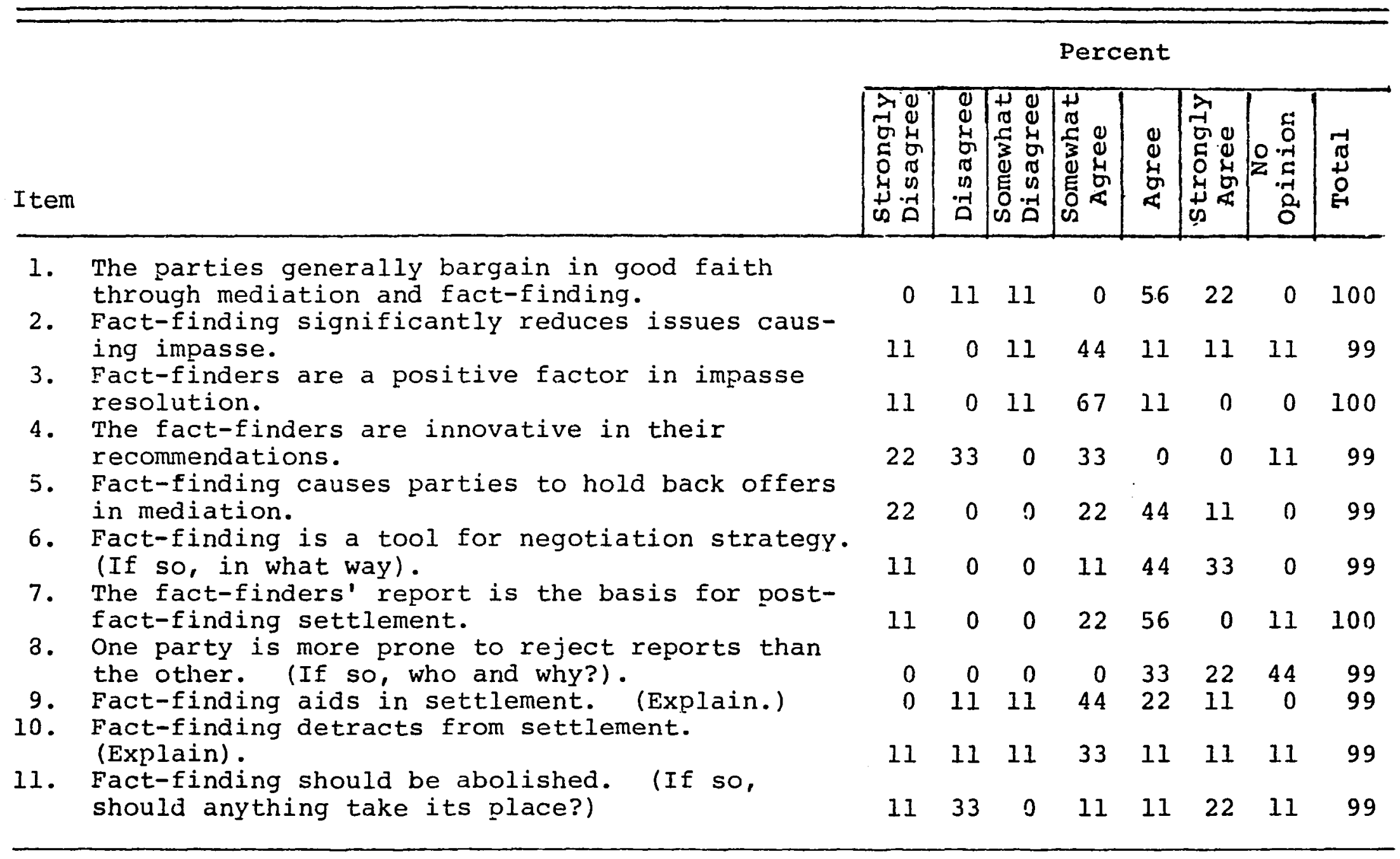


finding does significantly reduce the issues causing impasse. Sixty-six percent responded to item two in the agree portion of the scale. However, this can be interpreted differently because 44 percent of that group hedged by only somewhat agreeing, and because of added comments during the interview. Such comments included "they were ready to get together anyway," "some do, some don't," and "minor issues fall out, leaving the major ones."

Still, overall, two-thirds of the mediators do agree that fact-finding significantly reduces the number of issues causing impasse, even if a few major ones are left to be settled in post-fact-finding mediation (or after strike).

(3) Fact-Finders Are a Positive Factor in Impasse Resolution. Mediators, by a sizeable majority, felt that the fact-finders themselves are a positive factor in impasse resolution. Over 78 percent of them responded in the agree portion of the scale to question three. Specific comments about the positive role include, "the fact-finder listens to their arguement without interruption," "he moves them toward settlement," "for new groups he helps educate them." However all comments were not positive. Negative comments were made such as, "he can escalate problems if there is confusion over his report," and "they split issues to keep their jobs." This type of comment may also be an indication of professional jealousy. This reference to possible professional jealousy refers to the mediators' role and salary as compared to the fact-finders'. The mediators work long 
hard hours for the state and do not receive excessive payments for their services. Fact-finders (who are free agents) charge what the market will bear, and work at their convenience. Also mediators generally picture themselves as having superior knowledge and intuitive feel for the parties' positions and hidden agendas.

Overall, mediators generally think fact-firders play a positive role in the process, but there are circumstances where the fact-finder may not be a positive factor.

(4) Fact-Finders Are Innovative In Their Recommendations. Over 55 percent of the mediators felt that factfinders are not innovative in their recommendations. Further comments suggested that several mediators felt the fact-finders split the issues, rather than suggest innovative solutions to the impasse. This response may be due to the fact that mediators have to, and can, be innovative in their suggestions, but for practical purposes the factfinders only have a range in which to recommend, and that range is stipulated by the parties. Thus, when mediators compare their own experience with the fact-finders' they conclude (and perhaps rightfully so) that fact-finders are not innovative in their recommendations.

(5) Fact-Finding Causes Parties to Hold Back Offers in Mediation. Of great importance is the impact fact-finding may have on bargaining. Over 77 percent of the mediators felt that parties hold back offers in bargaining and mediation in anticipation of fact-finding. The reasons for this 
will be discussed when the parties' views are analyzed. The implication from the mediators is that fact-finding makes their job harder, as parties may hold back in spite of the quality of the mediator's effort. Again this will be explored in greater detail later in this and the next chapter.

(6) Fact-Finding is a Tool for Negotiation Strategy. The purpose of this question is to further ascertain the effect the presence of fact-finding may have on the bargaining process. Over 88 percent of the mediators thought that factfinding is used by the parties as a tool for negotiation strategy. Specific comments include: "the third party deflates high proposals," "fact-finding creates a sense of impatience and to get it over with," "parties know they will not get much less than the fact-finders' recommendation," "fact-finding used according to blidget time lines and elections," "used to hold back and pressure other party due to time lapse," "a delay tactic that costs money and brings in an unwelcome outsider," and "every phase used is strategy." These comments show that the ways in which fact-finding may be: used as a tool for negotiation strategy vary considerably, but further comment will be withheld until all participants' views are discussed.

(7) The Fact-Finders' Report is the Basis for PostFact-Finding Settlement. A sizeable majority (about 78 percent) of the mediators responded in the agree portion of the scale to item seven. This is a strong indication that although the fact-finders' reports are not accepted, they 
are very useful in impasse resolution. In Chapter $V$ the more general aggregate data showed that both parties accepted the fact-finding reports in only 17 percent of the fact-finding cases. This, on the surface, makes the process seem unsuccessful. However, consider two factors: (1) the large number of issues involved in the average factfinding case, and (2) the use of the report after factfinding. First, in spite of the quality of the factfinders' report, the large numbers of issues make it improbable that both parties will accept the report in total. Second, mediator responses to the questionnaire show that acceptance of the fact-finders' report, although desirable, is not necessary for the fact-finders' recommendations to be taken seriously by both parties.

It appears that parties use the fact-finders' report as a basis for settlement for some issues, to clarify positions on other issues, and as a reference point in postfact-finding negotiations and super-mediation. Perhaps the report's usefulness could be more adequately measured if the parties had to accept or reject on an issue by issue basis, rather than on the entire package (the thought being that many of the recommendations may be acceptable, and only a few need further negotiation).

In summary, the acceptance or rejection of an entire fact-finder's report is not an indication that the process has been unsuccessful in bringing the parties closer together and fostering a peaceful resolution of impasse. 
And, over three-fourths of the meajiators thought the reports are the basis for post-fact-finding settlement.

(8) One Party is More Prone to Reject than the Other. This question was posed to check whether mediators had a clear idea of the parties' actions on fact-finding reports. over 44 percent of the mediators had no opinion, which is an indication that the question is not a good one. For what it's worth, 55 percent of the mediators agree that employers between 1974 and 1977, were more prone to reject factfinders' reports. The aggregate data substantiates their opinions.

However, of considerable interest is the mediators' views as to why employers rejected reports more often than employee groups. The comments include: "a deliberate strategy [by management] to opt out of negotiations," and "school boards feel they are in control--they are paternalistic." These comments imply that employers rejected more fact-finding reports due to a strategy, a demonstration of power, and dislike for the collective bargaining process. Their comments also implied that employee groups accepted more reports because of a strategy of appearing reasonable and cooperative, plus the fact that most employee groups did not want to, or were not powerful enough to successfully engage in a strike. Several mediators suggested their recent experiences indicated a change in attitude or strategy by employee groups, and that the rejection rates by both parties may become more equal in the future. 
The implications drawn from these comments are that the high rate of rejections by employers is more due to attitudinal problems than problems inherent in the fact-finding process or the fact-finders' reports. Further comment will be withheld until the parties' views are considered.

(9) Fact-Finding Aids in Settlement. A large majority of mediators ( 77 percent) thought that fact-finding does aid in settlement. However, 44 percent did so in a mild way (that is, they somewhat agreed). Their explanations as to why it aids are summarized as follows: "it gives the parties an opportunity to publicly vent their feelings," "fact-finding forces the parties to re-evaluate their positions in a rational way," "fact-finding provides time to cool off," "the parties' political needs are satisfied," and "fact-finding gives a neutral's views and recommendations." Thus, according to the state mediators, factfinding does aid in settlement in several ways, however, it also detracts from settlement as the next question shows. (10) Fact-Finding Detracts From Settlement. A slim majority of mediators felt fact-finding does detract from settlement as 55 percent responded to item ten in the agree portion of the scale. However, over 33 percent hedged by somewhat agreeing, which is an indication that, overall, fact-finding detracts to a mild degree. Specific reasons given for such agreement are: "there is sometimes confusion over the fact-finders' recommendations," "fact-finding causes a hold back of offers, and delay tactics," "it 
lengthens the process," "fact-finding makes it more difficult to me:diate," and "it can cause complications with recommendations that are not realistic."

It is interesting to note that some of the aspects that make fact-finding an aid to settlement also can make factfinding a detraction from settlement. For example, the time lapse involved is viewed as a positive factor in that it gives the parties time to cool off and reassess their positions. However, that same time lapse can run into budget and election deadiines, or be used as a delay tactic to cause frustration.

The fact-finders' recommendations are also viewed from two ways. The:y provide a neutral's views which can help the parties uriderstand what is reasonable; on the other hand, if the recommendations are vague or unrealistic, further problems can result.

The two questions relating to fact-finding aiding or detracting from settlement are not mutually exclusive. They show that the mediators are torn themselves between whether the benefits outweigh the problems of fact-finding, and that fact-finding (like most things in life) is a doubleedged sword.

In order to come to grips of whether the process should be retained, the next statement was posed.

(11) Fact-Finding Should be Abolished. Mediators as a group are divided on this issue. About 44 percent fall in the agree, and 44 percent in the disagree portion of the 
scale; 11 percent had no opinion. Table XXXXII shows that those who disagree with this statement feel stronger than those who agree (none somewhat disagree, where 11 percent somewhat agree).

It must be emphasized that this statement is not a simple yes or no question; this was indicated by responses to the question: "should anything take the place of factfinding?" Of those who thought fact-finding should be abolished, half felt that the impasse process should consist of mediation only; that is, if mediation were to fail, the parties would go directly to strike. It is interesting to note that all mediators so responding have private sector experience. The other half who favored abolishing fact-finding suggested substitutes for fact-findirg, such as a thirty day cooling-off period, or binding arbitration. This shows that those mediators who favor abolishing factfinding differ significantly as to what should take its place. One reason for this may be that they put emphasis on different problems of the process. In short, only a few mediators suggested abolishing fact-finding with no replacement, and 44 percent would not abolish it al all.

Problems Perceived by Mediators

Although mediators did not form a clear consensus on retention of fact-finding, most had definite thoughts about what problems exist. with respect to the process. Possible solutions to the following problems will be discussed in 
the final chapter.

Too Many Issues. Table XVII in Chapter $\mathrm{V}$ showed the average number of issues per case is 15 . Mediators estimated an average between 25-30. The difference is whether the subissues are counted or not. In either case, with large numbers of issues it makes it all but impossible for a fact-finding report to be accepted, or for mediation to be successful. This is because the parties have been unable to accomplish much by themselves anyway. The reason for so many issues lies with the parties themselves and their unfamiliarity of, and lack of experience with, the collective bargaining process. Many mediators said time, and increased socialization in the process, will solve this problem; in the meantime, it will have to be dealt with as best as possible.

Delay Problems. The amount of time involved in factfinding, as shown by the aggregate data, is excessive and runs the impasse process past budget and election deadlines, and adds to the frustration levels of some parties. This is of particular concern to parties who go to interest arbitration as the law limits retroactive pay increases by requiring that interest arbitration be requested prior to the budget deadline of July first. Therefore, if fact-finding has not been concluded before July first, any pay increases awarded in arbitration will be for the following year, not that present fiscal year. One mediator sees 
time as taking steam out of the institutions, which may stop strike, but does not contribute to equity. He stated that public employees in many groups are represented by low budget representatives, whereas public employers have the money to afford 'pros' that get hired to buy time.

Fact-Finder Problem. This problem was mentioned by several mediators. It refers to the expertise of the factfinders and their ability to communicate findings in written form. Some mediators thought that fact-finders need to write more clearly and in a similar form. Furthermore, cases should be handled in a similar manner, and more uniform fees charged. In the opinion of one mediator, many fact-finders are trained in the private sector and are unfamiliar with the uniqueness of public sector labor relations.

Fact-Finding Too Intellectual. The success of factfinding rests upon the parties internalizing the intellectual basis of the process. Several mediators stated that the law is more intelligent than the people using it; that is, public employee collective bargaining at this stage is largely politics and emotion, and therefore, fact-finding is used to those ends rather than lised properly. The case is made that until the fact-finding phase is intellectualized among the institutions it will not be as useful as the law iritends.

Miscellaneous. Other problems mentioned by the mediators include the thought that fact-finding is great for the 
fact-finders as they make lots of money for writing reports that are not publishe:d or that the public can't understand. Whether such comments are a result of professional jealousy rathe:r than objectivity, remains for further analysis.

Another mediator mentioned that fact-finding is a process where the parties talk issues to death, and in essence expect the fact-finders to write the contract that the parties were unwilling to write themselves.

Finally, two mediators suggested that we ought to have a few more strikes in order to clear the: air, to educate the parties on the seriousness of the process, and get them down to good faith bargaining (the aggregate data showed Oregon has had only seven strikes from 1974-1977).

\section{Post-Fact-Finding Mediation}

Lastly, the question was posed as to why so many cases are settled after rejection of the report, but before the strike. Almost to the person, mediators thought that both unions and employers don't want a strike and it is not until after fact-finding that "push gets to shove;" that is, only after fact-finding does the pressure for parties to settle become strong.

Another explanation is that after fact-finding the parties have had similar views from two neutrals, thus are more able to compromise and save face. Lastly, many cases are settled in post-fact-finding mediation through the hard work of the mediator. 
Summary of Mediator Views

Table XXXXIII shows a summary of the mediators' views.

TABLE XXXXIII

SUMMARY OF MEDIATOR VIEWS ON FACT-FINDING

\begin{tabular}{lccc}
\hline Item & $\begin{array}{c}\text { Percent } \\
\text { Agree }\end{array}$ & $\begin{array}{c}\text { Percent } \\
\text { Disagree }\end{array}$ & $\begin{array}{c}\text { Percent } \\
\text { No Opinion }\end{array}$ \\
\hline 1. Good Faith Bargaining & 78 & 22 & 0 \\
2. Reduces Issues & 66 & 22 & 11 \\
3. Positive Factor & 88 & 22 & 0 \\
4. Innovative & 55 & 33 & 11 \\
5. Hold Back & 77 & 22 & 0 \\
6. Tool for Strategy & 88 & 11 & 11 \\
7. Basis for Settlement & 78 & 11 & 44 \\
8. One Party Rejects More & 55 & 0 & 0 \\
9. Aids in Settlement & 77 & 22 & 11 \\
10. Detracts from Settlement & 55 & 33 & 11 \\
11. Abolish Fact-Finding & 44 & 44 & \\
\hline
\end{tabular}

It shows that the mediators' overall assessment of factfinding is both positive and negative. A strong majority think the parties bargain in good faith according to the technical meaning, but question whether they bargain toward settlement. A majority feel fact-finding reduces the issues causing impasse. The vast majority some what agree that fact-finders are a positive factor in impasse resolution; and a slim majority do not think fact-finders make innova- 
tive recommendaticns. Mediators, by a good majority, think fact-finding causes parties to hold back offers in negotiations and mediation, and that the parties use the process as part of their overall bargaining strategy. A sizeable majority thinks fact-finding aids in settlement, and a slim majority thinks it detracts from settlement. Mediators are divided as to whether fact-finding should be abolished. Those who think it should be abolished differ considerably on what should replace the process.

The next section will relate the views of the factfinders, and conclude with a comparison of mediator and fact-finder views.

\section{THE FACT-FINDERS' VIEWS}

The educational level, occupational status and experience of the fact-finders interviewed reveals that they are not average in any respect. Over 80 percent of the factfinders have a Ph.D. or law degree, and the remaining have some college. The occupational background is as follows: attorney, 20 percent; educator, 50 percent; and mediatorarbitrator, 30 percent. 4 The number of years experience in fact-finding ranged from four to ten, with an average of six and one-half years. It is interesting to note that although there were 33 fact-finders involved in cases from 1974-1977, the ten interviewed account for about 64 percent of the total cases. This is due to re-selection by the parties. 
Reasons for Fact-Finding

Fact-finders attributed the cause of fact-finding to the same reasons as the mediators. In order not to be repetitious, these will not be discussed in detail but Iisted according to the frequency of response. The causes are: (1) hold-back strategy, (2) use as an extension of the bargaining process, (3) face-saving, (4) lack of good faith bargaining, and (5) miscellaneous items such as the mediator was not trusted, or the parties need more time.

Issues

When responding to the questions regarding the issues, the fact-finders indicated that most of the problems surrounding the issues involved in fact-finding center about the numbers and types of issues.

Numbers of Issues. The number of issues going to factfinding is of great concern to neutrals, because they indicate the degree of lack of bargaining by the parties involved. The average number of issues per case, according to the fact-finders' estimates, ranged from 15 to 50 with an overall average of 25. The aggregate data in Table XVII showed the average number of issues was 15, however, it was pointed out that some issues had as many as eight subissues. This accounts for the fact-finders' range in estimation. The greatest number of issues reported ranged between 28 and 100 , and the least number of issues ranged between one and 20. Fifty percent of the fact-finders 
reported cases with over 50 issues. It should also be noted that the public schools were mentioned as the scurce of most of the cases involving large numbers of issues. According to the fact-finders there are several reasons for this unmanageable number of issues. First, during the period 1974-1977, the collective bargaining law was new, and bcith parties were not very sophisticated in the art of collective bargaining. This lack of experience, as mentioned by the mediators, causes problems that result in impasse and eventually fact-finding. Second, there were certain areas in Oregon where the public school employers deliberately would not bargain on many issues in order to force the Employment Relaticns Board (via an unfair labor practice) to clarify what were mandatory and permissive items. ${ }^{5}$ Also many issues were taken to fact-finding in order to test the system, and the unions' strength. Third, some parties (again mainly in the public schools) were not willing to bargain and literally took the issues to factfinding in order to secure a contract; that is, they had the fact-finder write a contract by default.

In any case, the number of issues has declined recently and it is expected by all concerned that in the future the average number of issues per case will not be so extraordinary because of the parties' newly gained experience, particular ERB rulings, and past negotiations. If the number of issues decreases substantially, it may well be that the acceptance rate of fact-finding reports will 
increase, as the parties have fewer points on which to disagree.

Types of Issues. The: type of issues is another concern to neutrals. Fact-finders were asked to rank the most important issues that cause fact-finding. They are: salary and fringe benefits,

(2) grievance procedures, union rights and security, (4) just cause, (5) management rights, and (6) leaves. Several of these items only pertain to the education sector, which is expected given the majority of the fact-finding cases involved public schools. The: aggregate data from Tables XVIII and XIX in Chapter $V$ show these issues are among the ten most frequent issues submitted to fact-finding.

Issues (2), (3), and (4) show the attempt for labor to establish the same long"standing benefits that most unions have in the private sector. The most frequently mentioned issues that cause fact-finding were the economic issues (salary and fringe benefits); this may reflect the public employers' concern over increased expenditures in an atmosphere of tax revolt. One can conclude that this will remain the major cause of fact-finding for some time to come given the recent public concern in Oregon that clearly reflects an intolerance of increased public budgets and taxes. On the other hand, if the unions respond to this public concern they may change their priorities and put non-economic issues at the top of their bargaining list. Thus, the issues causing fact-finding could 
shift to the non-economic arena (such as just cause) in the near future.

Related to his, is the dilemma fact-finders face as a result of the ERB guidelines regarding mandatory, permissive and prohibited issues. ${ }^{6}$ As it now stands, the ERE guidelines are meant to assist the fact-finder in determining in which category a particular issue falls; and the fact-finder has tremendous discretion on how to handle permissive issues. As a result, three basic approaches are taken by fact-finders. First, a minority of fact-finders will not hear evidence on what they as individuals perceive as permissive issues. Second, a majority will hear evidence on all the issues submitted, and after looking at the ERB guidelines, only make recommendations on those which are mandatory. Third, a minority will hear evidence and make recommendations on all issues submitted. This later group thinks that the parties should sort these things out themselves or take them to the ERB for decision. In short, fact-finders may handle issues in one of several ways, depending on the wording of the proposed language and the fact-finders' personal view of this role. Further comment on this topic will occur in the final chapter.

The Effectiveness of Fact-Finding

To obtain the fact-finders' views as to the effectiveness of fact-finding in Oregon, 12 questions were asked. 
These questions and the fact-finders' responses are shown in Table XXXXIV. Each item will be discussed along with comments obtained in the interview. Because the reader is familiar with the items, a shortened form is used when titling the items.

(1) Good Faith Bargaining. Fact-finders are divided as to whether parties bargain in good faith through mediation and fact-finding. Of the responses to item one, 30 percent fall in the disagree categories, and 40 percent into the agree categories. Of interest is the fact that 30 percent had no opinion. This may be due to their lack of previous involvement in the impasse. Several said generalizing about the parties' conduct is difficult becalise the circumstances surrounding a case are varied, and therefcre, sometimes parties bargain in good faith and sometimes they do not. It was pointed out that parties may have bargained in good faith and have been near settlement when an external event occurred that may have had an adverse impact on the bargaining, and thus, the case ends up in fact-finding. Or some parties know months before negotiation that they would most likely go to fact-finding. The indication is that fact-finders are divided as to whether good faith bargaining occurs because, in their opinion, it depends upon the parties and the circumstances involved.

(2) An Effective Step. Not surprisingly, 80 percent 
Percent

\begin{tabular}{|c|c|c|c|c|c|c|c|}
\hline 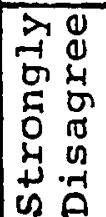 & $\begin{array}{l}0 \\
0 \\
1 \\
0 \\
\sigma \\
0 \\
0 \\
01 \\
0 \\
0\end{array}$ & 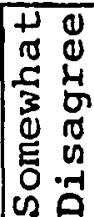 & 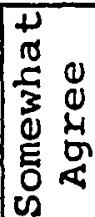 & $\begin{array}{l}\mathscr{U} \\
\stackrel{\leftrightarrow}{\alpha} \\
\stackrel{4}{\sigma}\end{array}$ & 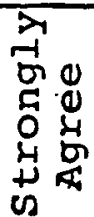 & 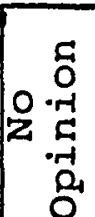 & $\begin{array}{l}\text { r- } \\
\text { d } \\
0 \\
0\end{array}$ \\
\hline
\end{tabular}

1. The parties generally bargain in good faith through mediation and fact-finding.

2. Fact-finding is an effective step in the impasse resolution process in oregon.

3. The parties discuss all issues before factfinding.

4. Parties use fact-finding to court favorable public opinion.

5. Publication of the fact-finding report encourages resolution.

6. The fact-finding process reduces the effectiveness of mediation.

7. The cost of fact-finding serves as a deterrent to its use.

8. Fact-finders should not engage in mediation.

9. Generally, parties make the fact-finder aware of their positions in mediation.

10. Positions taken in mediation (if known) influence the fact-finder's position.

11. The fact-finder should "call them as he sees them", and not split the issue.

12. Fact-finding should be abolished.

$\begin{array}{rrrrrrrr}0 & 20 & 10 & 0 & 40 & 0 & 30 & 100 \\ 0 & 10 & 0 & 0 & 50 & 30 & 10 & 100 \\ 10 & 20 & 10 & 0 & 40 & 20 & 0 & 100 \\ 10 & 20 & 10 & 30 & 10 & 10 & 10 & 100 \\ 20 & 0 & 0 & 30 & 40 & 0 & 10 & 100 \\ 10 & 0 & 0 & 40 & 0 & 10 & 40 & 100 \\ 20 & 10 & 20 & 30 & 0 & 0 & 20 & 100 \\ 10 & 0 & 10 & 20 & 20 & 40 & 0 & 10.0 \\ 20 & 20 & 10 & 30 & 0 & 10 & 10 & 100 \\ 20 & 20 & 10 & 50 & 0 & 0 & 0 & 100 \\ 0 & 0 & 0 & 20 & -30 & 50 & 0 & 100 \\ 40 & 40 & 0 & 10 & 10 & 0 & 0 & 100\end{array}$


of the fact-finders reported that fact-finding is an effective step in impasse resolution. This indicates that the fact-finders think the process is useful and worthwhile, although none mentioned that fact-findinci is also a lucrative business for those involved. Ten percent had no opinion and 10 percent felt fact-finding was not effective.

In comparison, Yaffe and Goldblatt reported in their New York state study that 72 percent of the fact-finders thought fact-finding was effective; 15 percent had no opinion, and 13 percent thought it ineffective. 7

(3) Issues Discussed Before Fact-Finding. Factfinders generally agreed that the parties discuss all issues before fact-finding. Sixty percent responded in the agree portion of the scale. However, 40 percent responded in the disagree portion of the scale, indicating that in some cases parties have not seriously bargained on all issues, yet they expect the fact-finder to propcse a reasonable solution. Again this problem reflects the inexperience of those parties, the unfavorable attitudes of some public employers toward the collective bargaining process, and ERB scope of bargaining decisions. Still, the majority did agree that all issues are discussed prior to fact-finding. This is one indication of good faith bargaining prior to fact-finding.

(4) Courting Public Opinion. Fact-finders were divided in their opinions of whether parties used fact-finding to court favorable public opinion. Some fact-finders 
suggested that the paries do not care about public opinion or are not worried about the impact public opinion has on settlement because it does not exist. Others thought parties used the hearing as a forum to express themselves and educate the public as to the parties' reasons for particular positions. It appears that in some areas public opinion is taken more seriously than in others, and therefore the parties' use of fact-finding as a way to educate the public varies.

(5) Publication of the Report. A majority of factfinders (70 percent) think that publication of the factfinders' report encourages resolution. However, this agreement is mild as 30 percent of that group only somewhat agree; 20 percent strongly disagree with the statement. Fact-finders believe publication does affect public opinion, and that the threat of adverse public opinion causes parties to settle. It is important to note that publication consists of releasing the report to the wire service, not to the hometown newspaper. This topic will be discussed under the parties' views.

(6) Effect on Mediation. When questioned as to whether the fact-finding process reduces the effectiveness of mediation, 50 percent of the fact-finders agreed. However, 40 percent of that group hedged by only somewhat agreeing, and 40 percent had no opinion. The point was made by several fact-finders that the answer to this questions is "it depends." For example, if parties are too far apart for 
a mediator to be of much service, he will put parties into fact-finding. After fact-finding the mediator becomes more effective in resolving the impasse during the cooling-off period where post-fact-finding mediation is so often used. In other cases the parties hold back in mediation knowing that fact-finding exists, thus using fact-finding as an extension of the bargaining process. In short, fact-finding may help or hinder mediation efforts depending on the parties involved and the circumstances, but there is no strong feeling by fact-finders that the process generally hinders mediation efforts.

(7) Cost As a Deterent to Use. Fact-finding theorists suggest that if the parties bear the cost of fact-finding it will serve as a deterent to its use. Oregon fact-finders generally disagree on this subject as 50 percent responded in the disagree portion of the scale, 30 percent in the agree portion, and 20 percent had no opinion. Several factfinders stated that the cost did deter use of fact-finding in smaller bargaining units. However, in larger units costs were not seen as an important consideration in going to fact-finding. In the case of a small unit these costs might be so burdensome that they could not afford to take legitimate issues to fact-finding. In such cases they may have to accept a contract that was a result of their lack of economic power rather than as a result of good faith bargaining by both parties. 
One fact-rinder suggested that the costs were too high, but added that they are evidently fair as the market forces of supply and demand dictate the prices. Presently the cost of a fact-finder ranges between $\$ 200$ and $\$ 300$ per day (the average is \$225) plus travel and secretarial expense. Because the average number of issues is high, it is not unusual for a case to cost several thousand dollars. (One was reported to cost nine thousand dollars.)

One might seriously question whether these uncontrolled market forces of supply and demand act in the interest of the parties, to say nothing of the cost to the taxpayer. Further discussion about the cost of fact-finding will occur in later chapters of this dissertation.

(8) Fact-Finders as Mediators. One area of controversy among labor relation theorists is whether factfinders should mediate. In Oregon the ERB discourages mediation efforts by fact-finders. However, individual fact-finders have their own opinions about this subject. Eighty percent of the fact-finders generally agreed with the statement that fact-finders should not engage in mediation, which is consistent with ERB policy and state law. It is interesting to note that 10 percent strongly disagreed. One fact-finder suggested a fact-finder should be willing to assume the role of a mediator in the event that both parties request the fact-finder to mediate.

By comparison, in Michigan (where fact-finders are also not supposed to mediate) over two-thirds of the fact-finders 
considered mediation appropriate and only one-third thought it inappropriate. 8 In the next chapter the parties' views will be compared to the fact-finders and further comments made.

(9) Positions in Mediation. Fact-finders had mixed feelings about the statement that generally parties make the fact-finder aware of their position in mediation. Fifty percent responded in the disagree portion of the scale. But 30 percent hedged by responding in the somewhat agree portion of the scale. Their comments suggested that parties do sometimes directly or indirectly present the other parties (or their own) position taken in mediation to the fact-finder. The reason for this is an attempt by the parties to show how unreasonable the other is, or to hope that the fact-finder will not make a recommendation less than the other parties offer in mediation. The problem posed by such information, and the reason for the question, is that such information may bias the fact-finder. Also such information could be construed by the other party as a breach of confidence (as discussion during mediation is intended to be confidential).

As a result of experiences resulting in such consequences, some public school employer representatives have insisted that the union representative sign a letter of understanding stating that all positions taken in mediation remain confidential. According to these representatives this document must be signed by the other party before 
mediation begins or the party will not cooperate. A sample of such a document may be found in Appendix D. Further discussion regarding this letter will occur in the chapter on the views of the parties.

(10) Mediation Positions Influence the Fact-Finder. The statement that positions taken in mediation (if known) influence the fact-finders' position was presented in order to determine whether the concerns demonstrated in question nine are realistic. The fact-finders were evenly divided (50-50) in their responses in the agree and disagree portion of the scale. However, there was greater strength in the disagreement area $(20$ percent strongly disagreed, 20 percent disagreed and 10 percent somewhat disagreed). This is in comparison to the 50 percent who hedged by only somewhat agreeing.

This question asks a lot of fact-finders in that it requires they admit that information that is supposed to be confidential actually biases their recommendations. The impressive thing is that 50 percent do admit they are scmewhat biased by this information. One fact-finder summed it up by suggesting that it is impossible to disregard such information, just as it is impossible for a jury to completely disregard the judge's direction to forget about a damaging comment that was made out of order in a court room. Given this problem, it is understandable that some employers have insisted that the letter of understanding be signed before the process begins. 
(11) Split the Issues? Fact-finders were asked to react to the statement that fact-finders should, as expressed in the jargon, "call them as they see them," and not split the issues. Splitting of the issues refers to a report that is favorable in fairly equal amounts to both parties. The intent of this question was to find Oregon fact-finders' attitude about the controversial subject of whether fact-finders should write reports that represent what the fact-finder thinks is just, or write a report that is acceptable to both parties.

Their reaction was the most unified in the survey as 100 percent fell into the agree side of the scale. In comparison, Yaffe and Goldblatts' New York state study showed acceptability (where the power relationship is considered) and compromise (splitting the difference) were the most important criteria in development of fact-finder recommendations. 9

The ramifications of the question are considerable, and the key word is "should" as opposed to "do." A few comments implied that, of course, the fact-finder should look for the most reasonable recommendations and put each case into perspective; that is, consider what is realistic in terms of parties accepting or rejecting, and the parties' future attitude toward that fact-finder. The dilemma is that if the fact-finder report favors one party too much, the other party may not select that fact-finder in the fut:ure. In this case, honesty is not the best policy 
because a fact-finder risks losing future business. However, there is the view that most parties do not pick factfinders solely on their decisions, but by their logic. The claim is that if the fact-finders' reasoning is clear, the parties do not fault the fact-finder, although the recommendation may not be to the parties' liking. Further discussion about this issue will occur in the next chapter where the parties' views are considered.

(12) Abolish Fact-Finding? The vast majority of factfinders in Oregon are strongly opposed to the idea of abolishing fact-finding. Eighty percent of the responses were in the strongly disagree and disagree portion of the scale. In spite of the problems involved, fact-finders think the benefits outweigh those problems. The benefits they mention are similar to those mentioned by mediators. In the meantime, fact-finders are very aware of some serious problems involved in the process.

\section{Problems Perceived by Fact-Finders}

The following problems are perceived by fact-finders as serious impediments to the success of Oregon's factfinding process. Although they will be discussed below, possible solutions will be presented in the final chapter.

Time. The amount of time that the process involves is too extensive. It results in additional expense and allows the parties to establish their own time frame in order to 
strike at the most effective time, or to purposely go past budget deadines, and to frustrate the other party. This type of strategic use of fact-finding undermines its purpose.

Costs. Some fact-finders say the costs that professionals have to charge are higher than "moonlighters" because of overhead. Therefore, a more competent and desirable fact-finder may not be chosen by the parties due to cost considerations. Related to costs is the problem that parties are often not prepared when they go to hearing, and fact-finders then are forced to use extensive time studying materials; which is reflected in the expense of the process.

Too Many Issues. Parties take too many issues to fact-finding which increases the time involved considerably. Some parties bring issues to fact-finding that had been tentatively agreed to. They do this because they believe the fact-finder may split the issues and they may be able to gain by submitting issues already "lost" by tentative agreement. This again distorts the intended purpose of fact-finding.

Another related problem mentioned was that of the inexperience of some fact-finders that results in improper handling of the hearing and/or reports. This problem can result in the neutral adding to the parties' problems and further complicating the issues, thus, reducing the possibility of settlement. 
Research Data. Some fact-finders think that there is a need of a research service provided by ERB to further aid the fact-finder in his recommendations. While one might sympathize with this, the intent of the law is for the parties to do the research and present the facts in a hearing. Such research is seen as a way to force the parties to view their situation more seriously. The fact-finder is in a quasi-judicial position. If parties were aware that ERB would provide a research service, they may be less prone to do their own homework and be even less prepared and less objective than they are at the present time.

On the other hand, there is a need for a better indexing system of fact-finders' opinions. This would allow fact-finders to share their experiences and reasoning with one another and the parties, which could aj.d in more consistent and understandable recommendations and more sophistication by the parties effected.

Scope of Bargaining. Of considerable interest is the problem posed by the Employment Relations Board's handing of the "scope of bargaining." Their decisions which have deemed some issues permissive, rather than mandatory, has led to a situation that prevents the parties from discussing important issues during collective bargaining and mediation. In some cases, parties (especially the OEA) will take such issues to fact-finding in order to have their position aired, knowing full well the fact-finder may not give a recommendation about such permissive issues. This will 
be discussed further in later chapters.

Personalities. Another problem rests upon various personalities among the parties and their negative views about public sector collective bargaining, one another, and the neutrals. Time, suggests one fact-finder, will take care of this problem.

Structural. Others feel that time is not enough; that there are structural problems built into the process. For example, because the protective services go to binding arbitration, fact-finding becomes a waste of time. Also in requiring all impasses to go to fact-finding, excessive time and monies are wasted, as parties know what they want (e.g. strike). The view here is that fact-finding should not be abolished totally (except for the protective services) but instituted upon the mediators' or parties' request. The call here is for more flexibility.

Summary of Fact-Finder Views

Table XXXXV is a summary of fact-finders' views. It shows that fact-finders are divided as to whether parties bargain in good faith prior to fact-finding. They generally agree that all issues are discussed before fact-finding. They are divided as to whether parties use the process to court public opirion. A majority think publication of the report encourages resolution. Fact-finders mildly agree that the process reduces the efforts of mediation. They do not think cost is a deterrent to its use. There is 
agreement that fact-finders should not mediate. They are divided as to whether parties advise them of positions taken inmediation, and whether such knowledge bias their judgment. They are to the person in agreement that the fact-finder should recommend what is just, rather than what is acceptable to the parties. Because of the benefits derived from fact-finding, they are strongly opposed to the idea of abolishing the process. However, they are aware of some problems that need to be resolved before it can be as effective as was originally hoped by the legislature.

\section{TABLE XXXXV}

SUMMARY OF FACT-FINDERS' VIEWS ON FACT-FINDING

\begin{tabular}{|c|c|c|c|c|}
\hline Item & & $\begin{array}{l}\text { Percent } \\
\text { Agree }\end{array}$ & $\begin{array}{l}\text { Percent } \\
\text { Disagree }\end{array}$ & $\begin{array}{l}\text { Percent } \\
\text { No Opinion }\end{array}$ \\
\hline 1 & Good Faith Bargaining & 40 & 30 & 30 \\
\hline 2 . & Effective Step & 80 & 10 & 10 \\
\hline 3. & Discuss Issues & 60 & 40 & 0 \\
\hline 4 & Court Public Opinion & 50 & 40 & 10 \\
\hline 5. & $\begin{array}{l}\text { Publication Encourages } \\
\text { Resolution }\end{array}$ & 70 & 20 & 10 \\
\hline 6 & Harms Mediation & 50 & 10 & 40 \\
\hline 7 . & Cost Deters Use & 30 & 50 & 20 \\
\hline 8. & Fact-Finders do not Mediate & 80 & 20 & 0 \\
\hline 9 & $\begin{array}{l}\text { Positions in Mediation } \\
\text { Known }\end{array}$ & 40 & 50 & 10 \\
\hline 10 & \#9 Influences Report & 50 & 50 & 0 \\
\hline 11 & Shouldn't Split Issues & 100 & 0 & 0 \\
\hline 12. & Abolish Fact-Finding & 20 & 80 & 0 \\
\hline
\end{tabular}


By way of comparison and sumriary the mediators and fact-finders' views will be presented.

\section{SUMMARY OF THE NEUTRALS'VIEWS}

Tables XXXXIII and XXXXV provided a summary of mediator and fact-finder responses to questions regarding the factfinding process. From the tables and the previous discussion the following general observations are made. Both mediator and fact-finders generally agree that good faith bargaining (in a legal, not a practical sense) occurs thrciugh mediation and fact-finding. The majority also agree that fact-finding is an effective step because it reduces the number of issues causing impasse, and the report is the basis for settlement.

Both neutrals indicate mediation efforts can be somewhat reduced since the parties may be prone to hold back offers and use fact-finding as a part of an overall bargaining strategy. They are also in agreement as to the basic reasons that cause fact-finding. These are inexperience, face-saving, hold back strategy, and hard bargaining (although other reasons may be present).

The basic problem confronting the process, as perceived by both neutrals, is that of too many issues. Other problems seen by mediators are delay, the fact-finders themselves, and the parties' lack of socialization in the process. Fact-finders saw the major problems as the lack of 
research data, ERB scope of bargaining decisions, the personalities involved, and structural aspects.

Although these problems exist, the combined opinion of the neutrals was in opposition to abolishing fact-finding, with the fact-finders feeling more strongly than the mediators. In short, it was implied that the process has more positive than negative aspects. The positive aspects are that fact-finding allows parties to save-face thrcugh third party views and recommendations, it provides a forum to vent feelings, an opportunity to re-evaluate positions, and time for emotions to ebbe.

Conclusions and recommendations regarding those views and problems will be presented in the final chapter, which follows the next chapter that deals with the views of the parties. 
${ }^{1}$ For example see Byrcin Yaffe and Howard Goldblatt, Factfinding in Public Employment Disputes in New York State (Ithaca: School of Industrial Relations, Cornell Univ. Press, 1971); William R. Word, "Fact-Finding in Public Employee Negotiations," Monthly Labor Review, 95 (1972), 60-64; Jack Steiber, and Benjamin A. Wolkinson, "FactFinding Viewed by Fact-Finders: The Michigan Experience," Labor Law Re:view, 28, No. 2 (1977), 89-101.

2 Lewis A. Dexter, Elite and Specialized Interviewing (Evanston, Ill.: Northwestern Univ. Press, 1970), pp. 7-8. Also see Hubert M. Blalock, Jr., Social Statistics, 2nd ed. (New York: Mc-Graw-Hil1, 1972), pp. 527-528.

3 Letter from Ken Brown, state Conciliator, dated 2 February 1979 .

${ }^{4}$ Similar backgrounds were reported in the Michigan and New York studies. See Steiber and Wolkinson, p. 97; and Drothing and Lipsky, p. 101.

5 For example, see ERB Recommended order Nos. C-278, $\mathrm{C}-279$, and $\mathrm{C}-280$, regarding unfair labor practices.

${ }^{6}$ See Shannon Wetherall, "Scope of Collective Bargaining in Education," Tips and Trends - Special Report (Olympia, Wash.: Washington State School Directors' Association, 1976), pp. 23-35.

${ }^{7}$ Yaffe and Goldblatt, p. 46 .

${ }^{8}$ Steiber and Wolkinson, p. 96.

${ }^{9}$ Yaffe and Goldblatt, p. 51. Also see Steiber and Wolkinson, pp. 99-100. 
CHAPTER VII

VIEWS OF THE PARTIES

This chapter of the dissertation will complete the analysis of fact-finding in oregon. Its purpose is to discuss the views of the parties involved in the process. A questionnaire similar to that given to the neutrals was administered to both employee and employer representatives during a personal interview situation. In orcer to avoid repetition, the reader is referred to the discussion in Chapter VI concerning the interviews and questionnaires, and to Appendix $\mathrm{A}$ where the methodological notes are provided. The following is the subsample of the parties:

(1) Employee Groups - - eight representatives of five unions were interviewed -- these unions account for almost 71 percent of all requests for fact-finding and over 80 percent of all non home rule cases going to hearing. It is assumed that the state level of these unions represent the general views of the locals and also formulate general union policy. A list of those interviewed is provided in Appendi.x B .

(2) Employers - eight employer representatives were interviewed -- these representatives are from a cross-section of governments and include public schools, state, city and counties, special districts, and protective services; thus 
the areas of concern are represented. A list of those interviewed is provided in Appendix B.

The apprcach taken here is to discuss both parties' views, question by question. The comparative data introduce:d is for information and is not intended to provide a comparative analysis.

Reasons for Fact-Finding

Those interviewed were asked to rank the five most important reasons that cause fact-finding. They listed many causes similar to those listed by mediators and factfinders; they also added their own. Details of those responses may be found in Appendix B. Although no one reason stood out as a single cause of fact-finding, there were several that were mentioned more frequently. It became clear upon analysis that several of the reasons are interrelated and not separable into neat categories. An attempt has been made in the following presentation to incorporate the parties' comments into the discussion of the causes. Lack of Experience. Both parties mentioned this most frequently as a cause of fact-finding, although union representatives ranked it higher than did management representatives. Union representatives' comments relating to this were: "some negotiators don't krow how to cut a deal," and "there's a lack. of understanding the issues and collective bargaining process." 
Union representatives also mentioned that at times personality conflicts become entwined in the negotiations, thus causing confusion and obstinance among parties. This also reflects lack of experience among the laymen on both sides who sometimes attempt to negotiate or involve themselves in some type of complex strategy.

Employer representatives" comments relating to inexperience were that "parties use fact-finding to do collective bargaining," and "the union believes it will get more by going to fact-finding."

In short, both groups think lack of experience is an important cause of fact-finding; the implication being that with more experience and socialization the parties will be less likely to go to fact-finding. However, other causes may make this wishful thinking, in particular the attitudes of the parties.

Attitudes. Although only a few respondents from each group specifically mentioned attitude as a cause of factfinding, there were several responses such as "unreasonable board or union" which are indications of an attitudinal problem. The union representatives' responses indicate that they think many employers do not really bargain. They claim this is especially true with school boards who are seen as paternalistic, unfamiliar, and even hostile to the collective bargaining process. One union representative suggested many of the school boards follow the Oregon School Board Association guidelines, whether they are reasonable or not. 
In the meantime, the OEA claims to have spent more than onehalf million dollars over the last five years to train negotiators in order to reduce the problems caused by lack of experience.

Employer representatives mention that employee groups" attitude is one of "wanting their cake and eating it too," that the unions have unrealistically high expectations and therefore bring on fact-finding.

These comments support the neutrals' position that inexperience and unfamiliarity with the collective bargaining process has been the cause of many fact-finding cases.

At Impasse. Employer representatives suggested more often than employee representatives that a major cause of fact-finding is that the parties are really at impasse, that they really disagree on certain issues and therefore do not easily compromise on these issues. It seems then, that what may be construed by the employees to be a poor attitude, is merely hard bargaining in the eyes of the employers. Further examples of important reasons that are interrelated with experience and attitudes follow.

Strategy. Both parties mentioned in equal frequencies that a major cause of fact-finding is strategy by one or both parties. This includes parties holding back offers in anticipation that the fact-finder will "split the baby" and recommend a compromise of the parties' final offer, whether reasonable or not. There also exists a strategy of stalling in order to run past buaget deadlines and special elections, 
or to just wear down the other party. There is not much one can say about the parties using fact-finding as part of a strategy, except that such pragmatism makes the procedure much less effective than it would be if this were not the practice.

ERB Rulings. Both parties expressed the view that certain ERB rulings that separate mandatory and permissive issues in collective bargaining have been the cause of factfinding. This is especially true in education where employee representatives claim that some very important issues have been declared permissive. The employee representatives feel that in order to air opinion and show the importance of collective bargaining on such issues, they must take these issues to fact-finding, even though a fact-finder may not rule on permissive issues. Employer representatives see the ERB rulings as an upholding of management perogatives, and that unions taking such issues to fact-finding are encroaching upon management rights.

In short, one cause of fact-finding centers about the serious debate among the parties over the ERB rulings as to what is bargainable under the law. OnIy a change in ERB rulings or consistence in upholding these rulings can reduce such use of fact-finding in the future.

Other Reasons. Other reasons mentioned were saving face, complex issues, mediators, and the parties' representatives showing they are working. To avoid repetition these causes will not be discussed here, and the reader is 
referred to the previous chapter for more detailed discussion.

Summary of Reasons

In summary, the reasons that cause fact-finding, as listed by the parties, are often interrelated and therefore do not fall into neat categories. However, analysis of the parties' responses indicates that the major causes of factfinding are (or are related to) inexperience and attitudes. The unions' representatives are particularly critical of the bargaining technique, and the purported unsophisticated and paternalistic view taken by the employers (especially school baords). Employer representatives think unions have unrealistically high expectations, and that fact-finding comes about because of hard bargaining and the employees trying to get more by going to fact-finding, rather than by employer attitudes.

Both parties point out that strategy, ERB rulings, and saving face are also important causes of fact-finding.

The Effectiveness of Fact-Finding

In order to ascertain the parties' views regarding the effectiveness of Oregon's fact-finding process, questions pertaining to that were asked. Tables XXXXVI, XXXXVII, and XXXXVIII show a summary of the questions and the parties' individual and combined responses in percentage terms. Each question will be discussed separately and all data presented are in reference to these tables. 


\section{Percent}

Item

\begin{tabular}{|c|c|c|c|c|c|c|c|}
\hline 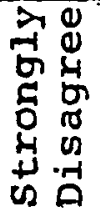 & 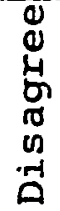 & 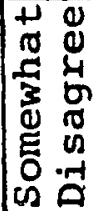 & 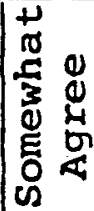 & 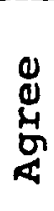 & 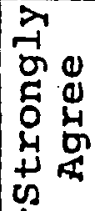 & 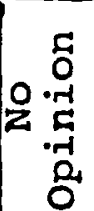 & $\begin{array}{l}\text { d } \\
+ \\
0 \\
0\end{array}$ \\
\hline
\end{tabular}

1. Fact-finding is useful in impasse resolution. Why or why not?

2. Generally we have confidence in fact-finders.

3. Fact-finders are a positive factor in impasse resolution.

4. The cost of fact-finding serves as a deterrent to its use.

5. Fact-finders engage in mediation (if so, at whose request?).

6. Fact-finders' recommendations are neutral (given the facts).

7. The other party generally bargains in good faith prior to fact-finding.

8. Fact-finding causes parties to hold back offers in mediation.

9. All issues are discussed before fact-finding.

10. Fact-finding reopens some issues.

11. The publication of a fact-finder's report encourages impasse resolution.

12. Fact-finding should be abolished.

$\begin{array}{rrrrrrrr}13 & 25 & 0 & 13 & 13 & 38 & 0 & 102 \\ 0 & 13 & 13 & 25 & 25 & 13 & 13 & 102 \\ 0 & 13 & 13 & 25 & 25 & 25 & 0 & 101 \\ 50 & 38 & 0 & 0 & 0 & 13 & 0 & 101 \\ 25 & 24 & 13 & 38 & 0 & 0 & 0 & 101 \\ 0 & 25 & 0 & 13 & 13 & 38 & 13 & 102 \\ 38 & 25 & 0 & 0 & 25 & 0 & 13 & 101 \\ & & & & & & & \\ 0 & 63 & 0 & 13 & 0 & 13 & 13 & 102 \\ 13 & 0 & 13 & 0 & 13 & 63 & 0 & 102 \\ 0 & 38 & 25 & 13 & 13 & 13 & 0 & 102 \\ 38 & 0 & 25 & 13 & 25 & 0 & 0 & 101 \\ 63 & 13 & 0 & 0 & 13 & 13 & 0 & 102\end{array}$




\begin{tabular}{|c|c|c|c|c|c|c|c|c|c|}
\hline \multirow[b]{2}{*}{ Item } & & \multicolumn{8}{|c|}{ Percent } \\
\hline & & 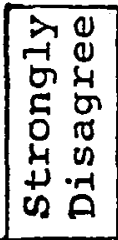 & $\begin{array}{l}0 \\
0 \\
0 \\
\vdots \\
0 \\
0 \\
0 \\
0 \\
-1 \\
0\end{array}$ & 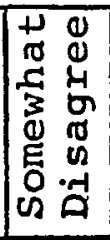 & 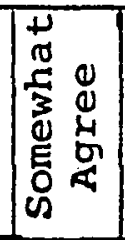 & 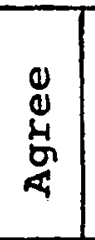 & 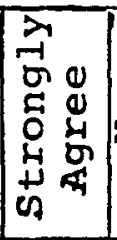 & 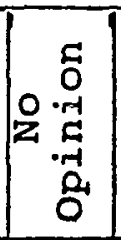 & 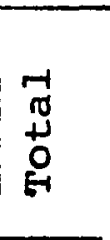 \\
\hline 1. & Fact-finding is useful in impasse resolution. & & & & & & & & \\
\hline & Why or why not? & 0 & 20 & 20 & 20 & 20 & 20 & 0 & 100 \\
\hline & $\begin{array}{l}\text { Generally we have confidence in fact-finders. } \\
\text { Fact-finders are a positive factor in impasse }\end{array}$ & 10 & 20 & 0 & 30 & 40 & 0 & 0 & 100 \\
\hline & $\begin{array}{l}\text { resolution. } \\
\text { The cost of fact-finding serves as a deterrent }\end{array}$ & 0 & 20 & 30 & 20 & 10 & 10 & 10 & 100 \\
\hline & $\begin{array}{l}\text { to its use. } \\
\text { Fact-finders engage in mediation (if so, at }\end{array}$ & 50 & 20 & 0 & 10 & 10 & 0 & 0 & 100 \\
\hline & $\begin{array}{l}\text { whose 'request?). } \\
\text { Fact-finders' recommendations are neutral }\end{array}$ & 0 & 20 & 40 & 20 & 10 & 10 & 0 & 100 \\
\hline- & $\begin{array}{l}\text { (given the facts). } \\
\text { The other party generally bargains in good }\end{array}$ & 0 & 0 & 30 & 10 & 50 & 0 & 10 & 100 \\
\hline 8. & $\begin{array}{l}\text { faith prior to fact-finding. } \\
\text { Fact-finding causes parties to hold back }\end{array}$ & 0 & 10 & 10 & 30 & 40 & 0 & 10 & 100 \\
\hline & offers in mediation. & 0 & 20 & 10 & 10 & 50 & 10 & 0 & 100 \\
\hline 9 . & All issues are discussed before fact-finding. & 0 & 40 & 10 & 0 & 50 & 0 & 0 & 100 \\
\hline $\begin{array}{l}10 . \\
11 .\end{array}$ & $\begin{array}{l}\text { Fact-finding reopens some issues. } \\
\text { The publication of a fact-finder's report en- }\end{array}$ & 10 & 30 & 0 & 20 & 20 & 20 & 0 & 100 \\
\hline & courages impasse resolution. & 40 & 20 & 10 & 10 & 10 & 10 & 0 & 100 \\
\hline 12. & Fact-finding should be abolished & 40 & 0 & 10 & 0 & 50 & 0 & 0 & 100 \\
\hline
\end{tabular}




\begin{tabular}{|c|c|c|c|c|c|c|c|c|c|}
\hline \multirow[b]{2}{*}{ Item } & & \multicolumn{8}{|c|}{ Percent } \\
\hline & & 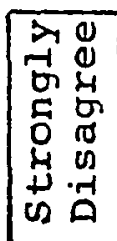 & 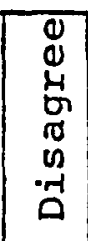 & 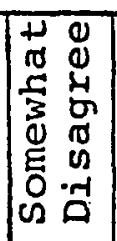 & 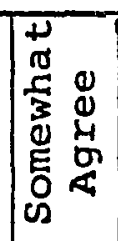 & 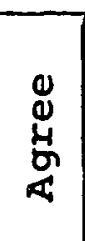 & 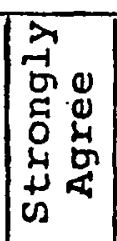 & 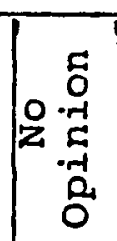 & 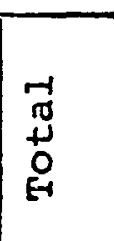 \\
\hline 1. & Fact-finding is useful in impasse resolution. & & & & & & & & \\
\hline & Why or why not? & 6 & 22 & 11 & 17 & 17 & 28 & 0 & 101 \\
\hline & $\begin{array}{l}\text { Generally we have confidence in fact-finders. } \\
\text { Fact-finders are a positive factor in impasse }\end{array}$ & 6 & 17 & 6 & 28 & 33 & 6 & 6 & 102 \\
\hline & $\begin{array}{l}\text { resolution. } \\
\text { The cost of fact-finding serves as a deterrent }\end{array}$ & 0 & 17 & 22 & 22 & 17 & 17 & 6 & $10]$ \\
\hline 5 & $\begin{array}{l}\text { to its use. } \\
\text { Fact-finders engage in mediation (if so, at }\end{array}$ & 56 & 28 & 0 & 6 & 6 & 6 & 0 & 102 \\
\hline 6. & $\begin{array}{l}\text { whose"request?) } \\
\text { Fact-finders' recommendations are neutral }\end{array}$ & 11 & 22 & 28 & 28 & 6 & 6 & 0 & 101 \\
\hline 7. & $\begin{array}{l}\text { (given the facts). } \\
\text { The other party generally bargains in good }\end{array}$ & 0 & 11 & 17 & 11 & 33 & 17 & 11 & 100 \\
\hline 8. & $\begin{array}{l}\text { faith prior to fact-finding. } \\
\text { Fact-finding causes parties to hold back }\end{array}$ & 22 & 11 & 6 & 17 & 39 & 6 & 0 & 101 \\
\hline & offers in mediation. & 0 & 39 & 6 & 11 & 28 & 11 & 6 & 101 \\
\hline 9. & All issues are discussed before fact-finding. & 0 & 22 & 11 & 0 & 33 & 28 & 6 & 100 \\
\hline $\begin{array}{l}10 . \\
11 .\end{array}$ & $\begin{array}{l}\text { Fact-finding reopens some issues. } \\
\text { The publication of a fact-finder's report en- }\end{array}$ & 6 & 33 & 11 & 17 & 17 & 17 & 0 & 101 \\
\hline & courages impasse resolution. & 39 & 11 & 17 & 11 & 17 & 6 & 0 & 101 \\
\hline 12. & Fact-finding should be abolished. & 50 & 6 & 6 & 0 & 33 & 6 & 0 & 101 \\
\hline
\end{tabular}


(1) Fact-Finding is Useful in Impasse Resolution. Why or Why Not? This question was asked in order to obtain the general thoughts of the parties regarding the process. A majority of both union and management responses fell into the agree side of the scale. Unions had 64 percent in the agree side, and of that, 38 percent in the strongly agree column indicating strong feelings. However, a strong minority of 38 percent of the union responses were in the disagree portion of the scale. Employer responses were 60 percent in the agree side and 40 percent in the disagree side, with a 20 percent distribution in all categories except strongly disagree. This reflects a lack of strong consensus of employer representatives with respect to this statement

By way of comparison, Yaffe and Goldblatt reported in their New York State study that 51 percent of the parties found fact-finding very effective in impasse resolution. ${ }^{1}$

In Oregon, the majority from both parties who think fact-finding is useful (in one degree or another) made the following comments: "it brings parties to reality and separates the wishbook issues from important issues," "it gives a new basis for bargaining through the third party influence," "it gives the super-mediator a report as a basis," "it is an educational tool in the backwater areas," "it allows parties to save face," "it provides a coolingoff period," "it helps to prevent strikes," and "it introduces more gentlemanly conduct into the collective 
bargaining process."

The sizeable minority from both sides criticize factfinding's usefulness by suggesting that: "it is not useful when both parties are experienced, informed and rational," "it is a waste of time for the protective services that go to binding arbitration," "it is too easy for parties who are insecure to leave the bargaining to a third party," "professionals are using fact-finding as a strategy," "it doesn't resolve anything the parties couldn't do at the table," "it causes holdback that undermines the negotiation process," "its benefits are over-shadowed by the substantial costs and time involved," "it doesn't get to the real issues that keep parties apart," and "fact-finders often try to be mediators or arbitrators."

In sum, a majority of both union and management representatives generally think fact-finding is useful, with the unions more positive than management. However, a strong minority on both sides (unions more negative than management) point out some serious problems that lead them to think it is not too useful. Suggestions on how some problems might be resolved will be presented in the last chapter of this study.

(2) Generally we Have Confidence in Fact-Finders. The intent of this question and the next question (\#3) was to obtain a general feeling of the parties about the factfinders themselves. The purpose was to obtain more information that relates to the high correlation between the 
fact-finders and the acceptance rate that was shown by the aggregate data in chapter $\mathrm{V}$.

Both unions and management responses indicate a general confidence in fact-finders as 63 percent of unions and 70 percent of management responded in the agree portion of the scale.

In comparison, Word reported that in Wisconsin 100 percent of the employers and 79 percent of the employees had a moderate to substantial degree of confidence in the factfinder; ar:d in New York it was 83 percent and 85 percent respectively. 2

In oregon, only 26 percent of union and 30 percent of management responses fell into the disagree portion of the scale, with management indicating more negative thoughts as 10 percent strongly disagreed and 20 percent disagreed. However, this should not be construed as a feeling of great confidence in fact-finders by both parties. A sizeable majority of both parties hedged by responding in the somewhat agree column (25 percent of union and 30 percent of management respcnses). This suggests that although both sides have confidence in fact-finders, it is a reserved confidence. Furthermore, it was mentioned by several individuals on both sides that they have more confidence in some fact-finders than others, and that the ones they deemed more competent were always busy and difficult to get. Still, 68 percent of the combined responses were in the agree portion of the scale, indicating a general confidence in fact- 
finders by both parties.

(3) Fact-Finders Are a Positive Factor in Impasse Resolution. Again, like question two, this question is intended to obtain the parties' overall view of the factfinders' role. Seventy-five percent of the union responses fell into the agree portion of the scale, indicating a strong feeling as to the positiveness of the fact-finders' role. Management views deviated from question two, as 40 percent responded on the agree side, and 50 percent on the disagree side of the scale. An explanation for this change may be that employer representatives have a general confidence in the fact-finders' capabilities, but do not feel the fact-finder can do much good, as the problems have to be worked out by the parties themselves.

In short, 75 percent of the unions, compared to 40 percent of management responses, indicate agreement that fact-finders are a positive factor. Management, by a slim majority does not view the fact-finders as a positive factor.

(4) The Cost of Fact-Finding Serves As a Deterrent to Its Use. The intent of this question is to ascertain whether the parties consider cost a serious deterrent to fact-finding. A very strong majority by both parties disagreed with the statement. Of the union responses, 88 percent, and of the management responses 80 percent were in the strongly disagree and disagree columns of the scale. 
By comparison, Word reported that in Wisconsin 56 percent of the parties said cost was not a deterrent to use, and in New York over three-fourths said if they had to pay it would not even moderately deter them from using factfinding. 3

There was one qualification regarding smaller bargaining units (say, under 50). In this case, the cost of fact-finding may be a serious burden. The claim was made that employers could take advantage of the situation in that a union, because it could not afford fact-finding, might agree to a contract that was not a real compromise rather than face the financial problems caused by factfinding. It was also mentioned that if fact-finding were free, more cases would result. In short, in Oregon cost is not a deterrent to either parties' use, except perhaps under circumstances involving a small bargaining unit.

(5) Fact-Finders Engage in Mediation. If So, At Whose Request? The purpose of this question is to find whether fact-finders assume a mediation or judgmental role; and therefore whether they are consistent with the law and ERB guidelines that expect the role to be that of adjudicator. A majority of both union and management representatives disagreed to question five. Sixty-one percent of their combined responses were in the disagree portion of scale, which indicates that mediation by the fact-finder usually does not occur. Of the union responses 38 percent somewhat agreed, indicating that sometimes it does occur. Union 
representatives' comments regarding this show that they do not approve of fact-finders who attempt to mediate. In fact, in several instances they evidently let the factfinder know that his mediation efforts were "not on." Although the majority (60 percent) of management representatives also disagree to the statement, they do not to the same intensity as unions. Of the management responses there were zero responses in the strongly disagree, 20 percent in the disagree, and 40 percent in the somewhat disagree columns. Furthermore, 40 percent did fall into the agree portion of the scale. Several comments by management representatives suggest that most fact-finders do not mediate, but some do and it's usually their (the factfinders') idea. Said one interviewee, "Some think they should -- you know shot putters always envy discus throwers."

A unique problem has occurred when parties from Oregon have a fact-finder from the neighboring state of Washington. In Washington, fact-finders are encouraged to mediate, and some have attempted this practice in oregon, only to find a cool reception by those involved. However, this is evidently not a serious problem at the present time.

By way of comparison, New York, like Washington, does not discourage mediation by the fact-finder; therefore Word's study showed two-thirds of the parties perceived mediation by the fact-finder. In Wisconsin, where mediation by fact-finders is discouraged, three-fourths of the parties 
reported only a little mediation. In both cases the parties prefer the judicial rather than mediator approach. 4

In summary, the combined views of both parties show a majority (61 percent) think fact-finders do not generally mediate. However, a strong minority (40 percent) did fall into the agree portion of the scale indicating that some do, in spite of ERB guidelines and the state law. This evidently is not a serious problem as the parties usually discourage such action on the spot. This and the general comments indicate that the parties support the concept that fact-finding should be more adjudicatory rather than mediatory.

(6) Fact-Finders' Recommendations Are Neutral (Given the Facts). This question is intended to obtain the general views of the parties regarding the neutrality and fairness of fact-finders. Overall the parties see the factfinders as neutral, as 61 percent of the combined responses were in the agree portion of the scale. Of the union representatives' responses, 64 percent were in the agree portion of the scale and 38 percent of those strongly agreed. Management responses were equally as positive as 60 percent fell in the agree portion of the scale (of which 50 percent were in the agree column).

From this question arose the question of what type of recommendations should the fact-finder make? That is, should the fact-finder recommend what he thinks is reasonable and fair, or recommend what he thinks is acceptable to 
both parties?

Both parties overwhelmingly preferred recommendations that are fair over recommendations that are based upon acceptance. Of the union responses, 100 percent, and of the management responses, 80 percent, said fact-finders should "call them as they see them" (recommend what he thinks is reasonable) and not "split the baby" (recommend what is acceptable). Furthermore, 75 percent of the union and 50 percent of the employer responses indicated factfinders usually do "split the baby." 5 what the parties prefer and what they get appear to be quite different.

Their comments indicated that parties are prone to be more firm in negotiations, and to take weaker and greater numbers of issues to fact-finding due to the fact-finders' reports following the acceptability doctrine. This is because in order to get what they consider a fair settlement, parties throw in some "losers" so the fact-finder can have something to take away from them as he splits the issues.

Both sides further indicated that it would be a great service to all concerned if fact-finders really did make recommendations that they thought were fair, rather than recommend what is acceptable. It is difficult to say whether the parties are kidding themselves, however, their enthusiasm indicates that further research in this area could prove very valuable. The concluding chapter of this study has some of this author's thoughts on the subject. 
(7) The Other Party Generally Bargains in Good Faith Prior to Fact-Finding. This question is intended to provide an indication of whether good faith bargaining precedes fact-finding, the implication being that the presence of fact-finding may have a negative effect on the bargaining process. There is disagreement among union and management as to whether one-another bargains in good faith prior to fact-finding. A majority of union representatives did not think employers generally bargain in good faith, as 63 percent of their responses were in the disagree portion of the scale. The intensity of their feeling is shown by the 38 percent who strongly disagreed with the statement. Management representatives thought the opposite. Seventy percent felt the unions do generally bargain in good faith. Reasons for the differences may be that the union responses may refer to good faith bargaining from a practical view, and management from a legalistic view. Also, certain public employers in Oregon have a reputation of being very difficult, and at times unreasonable at the bargaining table. Public schools and state government were often mentioned by neutrals and labor as falling into this category

It is interesting to compare the conflicting responses in a recent Oregon survey that showed the majority of union and management speakers felt the presence of fact-finding did not have a substantially detrimental effect upon negotiations prior to fact-finding. ${ }^{5}$ This may be interpreted 
as supportive of the concept above; that is, particular parties' attitudes, not fact-finding itself, are the major causes of lack of good faith bargaining.

It is expected that both sides will have occasion to state "my side is always reasonable," however when 63 percent of a cross-section of union representatives suggest there is generally bad faith bargaining, it becomes of great concern with respect to the effectiveness of factfinding. That is, it is questionable if fact-finding can be as effective as theorists believe if either or both of the parties do not bargain toward settlement in the first place. Further research might be directed to the reasons labor and manacjement so strongly disagree about this statement.

(8) Fact-Finding Causes Parties to Hold Back Offers In Mediation. The intent of this question is to further ascertain the impact fact-finding has on good faith bargaining. The parties perceive their actions much differently. About 63 percent of the union responses were in the disagree portion of the scale, compared to 70 percent of management responses that were in the agree portion of the scale. Party responses showed that while 70 percent of employer representatives admit to hold back, only 26 percent of the union representatives do so.

By way of comparison, Wolkinson and steiber reported in their Michigan study that 27 percent of the employers and 16 percent of the unions said they did hold back in 
anticipation of fact-finding. 7

The Oregon data may be interpreted in one of two ways. First, it may be viewed as supportive of the union representatives' feeling that employers often do not bargain in good faith (from a practical view, not a legalistic view); this sustajns the concept that the parties' attituce, not fact-finding, causes bad faith bargaining. Or, second, the employers do hold back offers in anticipation of factfinding, not because of uncooperative attitudes. One explanation for such action is that when the offers made in mediation are not confidential, a party may hold back offers because they think the fact-finder will use such information as a basis for the fact-finding report. This explains employer concern over confidentiality in mediation, and the use of the letter of understanding that was discussed earlier.

However, there is another way to view this, considering the comments made by the mediators, and the managementmediator consensus regarding hold back. It is possible that the unions do in fact hold back but do not perceive their actions in this way. An explanation for the unions' representatives not agreeing that they hold back is that unions may not know where their final position really is. The result is that at any one time they think they are not holding back, when in reality (after heavy nesotiations, mediation and fact-finding) they settle well below what they thought their final position was. In other words, they may have 
fooled themselves.

It is reasonable that all of these factors are present in different degrees depending upon the circumstances and the parties involved. Furthermore, it is of great concern to all involved that such a high percentage of management representatives admit to a hold back strategy because of its impact on the negotiation process. Further research into the causes of, and circumstances surrounding hold back could be very useful to policy-makers.

(9) All Issues Are Discussed Before Fact-Finding. The intent of this statement is to obtain parties' responses relating to their ability to bargain on issues prior to fact-finding in order to further ascertain the effect fact-finding has on negotiations. A sizeable majority of union representatives indicated that they think all issues are discussed at the bargaining table prior to factfinding ( 76 percent are in the agree portion of the scale). Employer representatives are split on this issue, as 50 percent are in the agree and 50 percent in the disagree portion of the scale. One possible reason that management deviates from the union fact-finder consensus regarding this statement is that in management's opinion, some issues are not discussed thoroughly at the table (rather than not discussed at all).

In comparison, the Michigan study showed that 80 percent of the parties concurred that all proposals and counter-proposals had been discussed before fact-finding; ${ }^{8}$ in a 
New York study about 75 percent concurred that this was the case. 9

In summary, collectively the parties agree 161 percent agree and strongly agree) that all issues are discussed prior to fact-finding, however, management agrees to a lesser extent than labor.

(10) Fact-Finding Reopens Some Issues. This statement is intended to reveal parties' thoughts concerning factfinding's impact on prior tentative agreements made during negotiation. The parties' views differ. A majority (76 percent) of union representative responses were in the disagree portion of the scale, indicating that they do not think issues are reopened in fact-finding. Management, on the other hand, generally agree that fact-finding does reopen some issues (60 percent were in the agree portion of the scale).

By way of comparison, the Michigan study showed that in 93 percent of the cases the parties indicated that factfinding did not have the effect of reopening previously settled issues. 10

The disagreement among oregon parties may be explained by the fact that sometimes several issues are related to one another and if one is not settled then they all are sent to fact-finding. Also issues may be reopened because of strategic reasons. For example, a party may feel they have everything to gain and nothing to lose by taking a tentatively settled issue to fact-finding. It has also been 
suggested that one employer's settlement may hinge on other employers settling also (e.g. school districts). In this case a tentative settlement may go to fact-finding because of a situation in another district.

However, the comments made here are made from a general perspective provided by the study, and it is not exactly clear why union and management representatives disagree as to whether fact-finding reopens some issues, given the information collected in the questionnaire.

\section{(11) The Publication of a Fact-Finders' Report}

Encourages Impasse Resolution. The intent of this question is to find whether parties agree with the theory that publication of the report brings about public pressure which encourages the parties toward settlement. Contrary to factfinders' opinions, it is clear that both parties do not think publication encourages settlement to a significant degree. A majority of union representatives $(63$ percent in the disagree portion of the scale) and a majority of management representatives $(70$ percent in the disagree portion of the scale) discount the importance of publication of the report. Comments by both parties indicate that the public is really not interested and not able to understand many complicated issues.

In comparison, the studies done in Michigan, Wisconsin, and New York State also indicate that publication of the report and public pressure does not significantly encourage the parties to settle. 11 
However, there are several reasons that parties in Oregon may be less concerned than they would be otherwise. First, many of the reports are not published because one or both parties take no action on the report (this was discussed in the previous chapter). Second, although the ERB gives the report to the wire service, that does not guarantee the local paper will pick it up or understand or clarify issues. Under circumstances such as these, it is not possible to really know what impact adequate publication would have on impasse resolution. Additional comments concerning publication will be made in the concluding chapter of the study.

(12) Fact-Finding Should Be Abolished. Again, the intent of this question is to find whether, on balance, the parties prefer to abolish fact-finding. The majority of the combined responses were against the abolishment of factfinding. However, the parties differed.

The unions strongly disagree with the idea of abolishing the fact-finding process as 76 percent of the responses were in the strongly disagree and disagree portion of the scale. Employers, on the other hand, were divided with 50 percent in the agree portion and 50 percent in the disagree portion of the scale. However, the strength of employer disagreement was greater than those agreeing (40 percent strongly disagreed and 50 percent only somewhat agreed). This indicates that one-half of management representatives hedged as to whether to abolish fact-finding; and none 
agreed or strongly agreed to the statement.

The combined percentages were 62 percent against abolishing and 38 percent for abolishing fact-finding. In addition, one-half of those against abolishing fact-finding strongly disagreed to such a proposal. Reasons for the positions are the same as those under question one. When the 38 percent who would see fact-finding abolished were queried as to what should replace fact-finding, their responses were considerably varied. One suggestion was that the process should go from mediation directly to strike; another that fact-finding should be dropped if binding arbitration is present; another to replace fact-finding with a 30 day cooling-off period, then super-mediation before strike. It was noticed that those individuals who have had private sector experience were most prone to favor abolishing fact-finding and not replacing it with anything (an emulation of the private sector). This is ironic given the recent serious discussion in the private sector about using fact-finding and arbitration to a greater extent in order to avoid costly strikes.

In short, a majority of union representatives and 50 percent of management would not abolish fact-finding. This however, does not suggest that serious problems do not exist. On the contrary, when asked about the problems of fact-finding in Oregon, parties' responses were numerous. 
Problems Perceived By Parties

The parties perceived some problems similar to those perceived by the neutrals. To avoid repetition only those: problems which are dissimilar will be discussed in detail in the following order: lack of preparation, non-binding recommendations, protective services, cost, fact-finders, time, inexperience, and others.

Lack of Preparation. Union representatives in the education sector suggest there is a lack of preparaticn on the part of some school districts who have a tendency to not take fact-finding seriously. This puts the fact-finder in the position of having to do his own research. Also it is claimed that management in such cases does not take what the fact-finder recommends seriously, thus the purpose of factfinding is thwarted.

Non-Binding Recommendations. Because the recommendations are not-binding, either party can use the process for strategic reasons and not suffer any dire consequences. Says one union representative, "fact-finding eliminates strikes, but slows the process to the benefit of the employer;" this statement is made because if either party will not compromise after the report is issued, strike is the only weapon left to resolve the impasse--which unions are reluctant to do.

Prctective Service. Several representatives from both sides thought fact-finding for police and fire is a waste of time and money. They pointed out that in this case, 
fact-finding merely served as a trial or practice run for binding arbitration.

Cost. High and vague costs were mentioned more often by union representatives as being a problem. This is because tax monies are used by public employees to cover factfinding costs, whereas unions cover their cost from a very limi.ted base of union dues. Furthermore, there have been instances where the fact-finder fees changed from that reflected on the Conciliation Service resume sent to the parties. One union representative suggested state limits on fact-finders' fees be instituted.

Fact-Finders. Both sides are concerned about the factfinders themselves as a problem with the process. Some fact-finders have had less experience than the parties, and have been unfamiliar with the problems involved. They claim there is too much variety among approaches, use of criteria of judgment, and overall competency. They think that the ERB screening process, training, guidelines, and feedback mechanisms are inadequate.

Time. Both sides emphassize how the time involved in the process poses serious problems with respect to budget deadines, arbitration award rules, and frustration levels.

Inexperience. Several union representatives suggested the major problem with fact-finding is that the parties themselves are inexperienced, immature, and don't really want to bargain. As a result the process is used as a vehicle for stalling. One management representative 
supported this concept by pointing out that critics are in the way of the process; that they do not try to use it effectively and therefore it doesn't work well many times.

Miscellaneous Problems. Complications in bargaining caused by the inherent conflict between civil service regulations and collective bargaining was mentioned as a reason that fact-finding is not so successful. Also, ERB rulings have complicated, in the view of some parties, the entire collective bargaining process, which of course includes fact-finding.

Summary of Parties' Views

The data from Tables XXXXVI-XXXXVIII show that both union and management representatives generally agree that fact-finding is useful in impasse resolution. They have general confidence in the fact-finders, but disagree as to whether the fact-finder can be: a positive factor, given the state of the art. Both union and management agree that the cost is not a deterrent to its use, except under unusual circumstances. Both sides also generally agree that factfinders do not often attempt to mediate, and that the parties like it that way. The parties view the fact-finders' recommendations as neutral, but complain that fact-finders more often split the issues than not. The parties disagree as to whether one another bargain in good faith; the union representatives indicating management does not, and management indicating that unions do, generally bargain in good 
faith.

Both disagree as to whether fact-finding causes parties to holä back during negotiations and mediation, with the unions indicating they do not hold back and management admitting they do. Both generally agree that all issues are discussed before fact-finding, but they disagree as to whe:ther fact-finding reopens issues. According to both parties, publication of the report does not seem to ericourage resolution. Union representatives strongly oppose abolishing fact-finding, where employer representatives are divided on the issue. They both point out serious problems with the process, although overall they would not like to see it abolished.

The views of the parties and those of the neutrals will be contrasted in the following chapter, which presents a summary, conclusions and recomnendations. 
CHAPTER VII NOTES

${ }^{1}$ Byron Yaffe, and Howard Goldblatt, Factfinding in Public Employment Disputes in New York State: More Promise Than Illusion (Ithaca: School of Industrial Relations, Cornell Univ., 1971), p. 46.

${ }^{2}$ William R. Word,"Fact-Finding in Public Employee Negotiations," Monthly Labor Review, 95 (1972), 64.

$$
\begin{aligned}
& 3_{\text {Word, p. }} 61 . \\
& { }^{4} \text { Word, p. } 62 .
\end{aligned}
$$

5 Because item seven elicited responses from the first half of those interviewed that indicated the problem of reports being written for acceptance rather than fairness, this question was asked of the last half of those interviewed.

${ }^{6}$ Lloyd Arthur Rawlings, "A Field Study of Oregon's Factfinding Procedure," Thesis. Univ. of Oregon 1977.

${ }^{7}$ Benjamin W. Wolkinson, and Jack Stieber, "Michigan Fact-Finding Experience in Public Sector Disputes," The Arbitration Journal, 31 (1976), p. 231.

${ }^{8}$ Wolkinson and Stieber, p. 231.

${ }^{9}$ Yaffe and Goldblatt; p. 24.

${ }^{10}$ Wolkinson and stieber, p. 231.

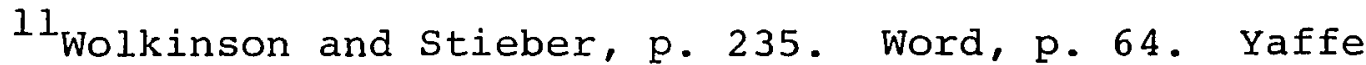
and Goldblatt, p. 37. Edward B. Krinsky, "An Analysis of Fact-Finding as a Procedure for the settlement of Labor Disputes Involving Public Employees," Diss. Univ. of Wisconsin 1969 , p. 213. 
CHAPTER VIII

SUMMARY, CONCLUSIONS AND RECOMMENDATIONS

The purpose of this dissertation was to examine the characteristics and effectiveness of Oregon's fact-finding process. This was accomplished through a review of relevant literature and Oregon law, analysis of aggregate data pertaining to fact-finding, and by structured interviews of participants engaged in fact-finding.

Review of the literature demonstrated that public sector collective bargaining is recent and occurs at all levels of government and in all states. It has as its objectives the bringing of order into public sector labor relations. The present and potential impact this recent phenomenon has for our traditional political and economic power structure is considerable. These changes have, and will continue to have, a significant impact on urban areas, where most of the population resides and union membership exists. Of particular concern is the impact this has on the allocation of limited resources in the budgetary process, and the threat of work stoppages (strikes) that interrupt the provision of vital public services. Of paramount importance has been the development of impasse resolution procedures which are intended to protect the public from strikes, while encouraging voluntary collective bargaining in the public sector. The 
Oregon Legislature's response to this challenge was the passage of a very progressive and comprehensive public sector labor law in 1973 .

\section{Oregon Public Sector Law}

The intent of Oregon's 1973 public employee bargaining law was to establish uniform procedures for labor relations in the public sector. It embraces the philosophy that it is in the public interest to have harmonious relations between governmental units and their employees, and that collective bargaining is a vehicle that can accomplish this. The law extends bargaining rights to public employees that are similar to those granted the private sector in the 1930's. The law grants the right to strike to all but those employees in the protective services. In order to protect the public from public employee strikes, the law established a multistep impasse resolution procedure should collective negotiations break down.

Oregon's impasse resolution procedure may be viewed as a filtering process with each step significantly contributing to the orderly resolution of disputes, reducing the possibility of public employee strikes, and encouraging the parties to settle voluntarily. Figure 3 is a flow chart showing the basic steps in the process. Each step introduces a higher level of intervention by the neutral third party. It is the fact-finding process that is most controversial and the topic of this dissertation. 
MEDIATION

FACT-FINDING

COOLING-OFF

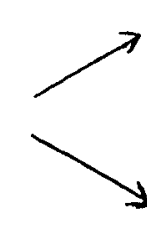

STRIKE

or

INTEREST

ARBITRATION

\section{NEGOTIATIONS}

Figure 3. Oregon's Impasse Resolution Process

\section{Oregon's Public Sector}

The present and potential impact of public sector collective bargaining in Oregon was couched in terms of an impact or penetration study.

It showed that there are almost 1,600 governmental units in Oregon (including school and special districts) that could be potentially involved in collective bargaining; furthermore there are over 1,000 bargaining units that are currently involved in collective bargaining and/or meet-andconfer discussions.

The study also provided estimates of the percent of the total governmental units in each sector that are involved in collective bargaining. The most conservative estimates of penetration are as follows: public schools - 95 percent, community colleges - 100 percent, state - 77 percent, counties - 56 percent, cities - 41 percent, and special districts - 10 percent. 
The potential impact could result in some 150,000 public employees being organized, and involve over 2,400 separate bargaining contracts.

Given this high level of activity, it is of great concern that the impasse resolution process be an effective way to avoid public sector strikes while encouraging voluntary collective bargaining.

\section{The Concept of Fact-Finding}

The concept of fact-finding is that the issuance of a neutral's findings and recommendations, along with public pressure, will encourage the parties to drop extreme positions and to settle voluntarily. Oregon law requires the parties to bear the cost of fact-finding as an inducement to settle in mediation prior to fact-finding. Furthermore, publication of a rejected report is thought to be a way to place public pressure on the parties to settle. This dissertation generated information to describe the characteristics and ascertain the effectiveness of this process.

Summary of the Aggregate Data

The aggregate data reported shows that one intention of Oregon's impasse resolution procedure is working: that is, each step significantly reduces the number of impasses and therefore the number of potential strikes. The factfinding phase accomplishes this also as almost 35 percent of the fact-finding cases were settled prior to the hearing, and only 5 percent of the cases going to hearing resulted in 
a strike.

The aggregate data further shows that the greatest use of fact-finding occurs in the education sector, and in particular, involves public schools and the OEA which represents $(\mathrm{K}-12)$ teachers. There appears to be a mild statistical association between employee actions and the employee organization and type of government involved. Employer actions have a mild statistical association with the employee group they are dealing with.

Although time has little statistical association with the parties' actions, the author is reluctant to dismiss this as unimportant because of information provided by the interviews and questionnaires. Population and census type data reveal that the vast majority of cases occur in urban areas; however, statistical association between census type and parties' actions is mixed and inconclusive. Of particular interest is the moderate statistical association between both parties' actions and the fact-finder himself.

Even though the statistical measures indicated only mild association between most of the variables, it may be that future research will yield different results as longer time periods are studied, and as the parties gain more experience with the process.

Furthermore, the fact that only 17 percent of the factfinding reports are accepted should not be construed to mean the process is ineffective in encouraging the parties to settle voluntarily; evidence from the interviews suggest 
the contrary.

Summary of the Participants' Views

The information gained from the interviews and questionnaires indicate that there is a tremendous range of viewpoints among the categories of participants and within each category. The information shows that some assumptions about fact-finding are confirmed, while others are not. It also shows that while fact-finding in oregon does fulfill some particular needs, it also results in certain problems. Both the problems and benefits will be discussed after the participants' views are summarized. Their views are covered. as follows:

Usefulness. A majority of the parties and the neutrals agree that fact-finding is useful in impasse resolution because it allows parties to save face through third party recommendations, it provides the opportunity for parties to reassess their positions, it acts as a forum to vent feelings under controlled conditions, it gives time for emotions to ebb, and it is a vehicle to socialize or educate the parties in the collective bargaining process.

Cost. Both parties and neutrals agree that the cost of fact-finding does not serve as a deterrent to its use. The only exception might be those small units (under 50) where there are not enough members to offset the factfinding costs without undue burdens. Their comments indicated, however, that if it were free there probably would be a higher usage of fact-finding. 
Hold Back. Mediators and management concur that factfinding causes hold backs during negotiation and mediation. Unions view this as not the case. However, there is evidence that anti-collective bargaining attitudes, not just presence of fact-finding, also cause hold-backs.

Publication. The parties do not see publication of the report as encouraging resolution. Although fact-finders disagree with the parties, it is concluded that public pressure due to publication is not regarded as a viable force toward settlement.

Issues Discussed. Fact-finders and both parties agree that generally all issues are discussed prior to factfinding. This indicates that the presence of fact-finding does not significantly affect the number of issues going to fact-finding. The large average number of issues per case are attributed mainly to the parties' inexperience and attitudes.

Mediation. The parties and the fact-finders agree that the role of the fact-finder should be adjudicatory, and mediation efforts should not be made by the fact-finder. This is supportive of the philosophy embodied in Oregon law.

Confidence. The parties and mediators have a guarded general confidence in fact-finding, but disagree whether fact-finders can be very effective.

Neutrality. Both parties perceive the fact-finders as neutral but think recommendations should be based upon fairness not acceptability. Fact-finders agree to the person 
with this philosophy.

Good Faith Bargaining. Mediators and management concur that the parties bargain in good faith prior to factfinding, while the fact-finders are divided, and the unions disagree. The key to this disagreement is whether good faith bargaining has occurred in a legalistic or practical sense. There is evidence that some employees, in particular the public school and state sectors, often do not bargain toward settlement prior to fact-finding.

Abolish Fact-Finding? The unions and fact-finders strongly oppose this suggestion, while mediators and management are divided in their opinions. The overall opinion of the participants is to retain the fact-finding process. The majority, who oppose abolishing the process see the benefits as outweighing the problems. The minority see the opposite. A brief summary of the benefits and problems listed by those interviewed follows.

\section{Benefits of Oregon's Fact-Finding Process}

The items discussed below are generally perceived by various participants as being beneficial. Of course several items are also the source of some problems.

Neutral's Recommendation. Many are convinced (in particular the neutrals) that a neutral's recommendations are necessary in order to help the parties put the issues into perspective, and provide the parties and the public with a relatively unbiased view. The report is seen as being in 
the interest of both the parties and the public. For example, in this age of "tax revolt," the fact-finder can tell the public what is fair and reasonable, thus making it easier for employers to make decisions regarding increased expenditures.

Face-Saving. Both the parties and the neutrals are convinced that the fact-finding phase provides an avenue for compromise that allows the parties to save face. This has been particularly important during the first years under the law, where both parties have been adjusting to their new relationship. Its potential usefulness could be considerable if the home rule issue is settled in favor of the state law.

Education of the Parties. Although many of the parties disagree, the neutrals see fact-finding as a way to educate the parties in the collective bargaining process and impasse resolution, especially during the first years under the new law.

Time. The time involved in the process is seen as a period in which the parties have the opportunity to cool off and re-assess their positions.

Vent Feelings. The neutrals point out that the hearings serve a psychological function as parties can publicly vent their feelings under controlled conditions. In this case a party may be ready to settle once they have "had their say." 
Fewer Issues. According to mediators, fact-finding does contribute to reducing the number of issues leading to impasse, making settlement easier in super-mediation, in spite of the fact that the vast majority of the reports are not accepted in total.

Few Strikes. Only five percent of the cases going to hearing result in strike. This implies that the factfinding process contributes significantly to the reduction of impasses going to strike.

\section{Problems of Oregon's Fact-Finding Process}

Inexperience. The most often mentioned problem is the parties' inexperience with the philosophy and technigues of collective bargaining.

Attitude. Related to inexperience are the attitudes of parties who are immature and allow personal feelings and past practice to interfere with collective bargaining and the usefulness of fact-finding. This is reflected in the number of issues taken to fact-finding.

Fact-Finders. Some fact-finders have been inexperienced. Generally, there is lack of consistency in format and criteria of judgment on permissive issues.

Structural Problems. Fact-finding has not been effective in cases that go to binding arbitration.

Time. The excessive length of time involved poses many conflicts with budget and interest arbitration deadlines. Furthermore, it is seen as causing frustration among parties. 
Costs. Excessive and non-standardized fact-finder fees are seen as a impediment to obtaining the most competent fact-finders.

Summary

In summary, the aggregate data and interviews show that the fact-finding process in Oregon's impasse resolution procedure does accomplish its purposes in that (1) it contributes significantly to the reduction of impasses, and thus the potential number of strikes, and (2) it encourages the parties to settle voluntarily as it provides a way for parties to re-assess their position, an opportunity to saveface, and to publicly vent their feelings, and a vehicle to socialize the parties in the collective bargaining process. Because of these advantages the majority of the participants do not want to abolish oregon's fact-finding process; rather they view it as a double-edged sword that provides many problems as well as benefits. The final section of this chapter will propose various recommendations that are intended to reduce the severity of many of these problems, and thus, improve oregon's fact-finding process.

\section{PROBLEMS AND PROPOSED SOLUTIONS}

It is recommended that the fact-finding process be retained because of its overall effectiveness in reducing the possibility of strikes and encouraging the parties to settle voluntarily. Many of its problems can be partially 
legislative action would not result in any serious negative aspects .

\section{Quality of Fact-Finders}

The interviews indicated that the parties and neutrals alike felt that serious problems exist with respect to the competency of some fact-finders. This was further demonstrated by the aggregate data that showed that although over 30 fact-finders were on the list, about 65 percent of all cases went to 10 fact-finders. Re-selection of those 10 is due to the parties not knowing some, and finding others incompetent.

Most of the problems relating to the quality of factfinders could be alleviated by the Conciliation Service placing and retaining only the most qualified on the factfinders' list. This would require a more careful training and screening process. To accomplish this, the following is recommended:

(1) Fact-Finder Training. It is recommended that both pre-entry and post-entry training be required of fact-finders on the list.

Pre-Entry Fact-Finaing Apprenticeship. It is recommended that the State Conciliation Service institute and supervise a fact-finding apprenticeship program. The intent of such an apprenticeship would be to insure a reasonable and consistent quality and quantity of fact-finders. Interested individuals, who are identified by the service to 
solved, or at least curbed, by administrative directions from the ERB and the state Conciliation Service Division. Other problems can only be dealt with effectively by an act of the legislature. The following problem areas and recommendations are not discussed in order of importance. They. are discussed in the following order: protective services, quality of fact-finders, issuance of reports, number of issues, parties' action on reports, publication of reports, fact-finder fees, scope of bargaining, attitudes, and budget deadines.

\section{Protective Services}

The aggregate data and interviews showed that those groups required by law to use binding arbitration as the final stage of impasse resolution do not find fact-finding useful. Neutrals agree that in this case, fact-finding is little more than a trial run for the arbitration hearing, and that it uses up precious time causing some cases to go past the July first budgetary deadline for arbitration requests. In short, fact-finding for protective services wastes time and money (about two months and 2,000 dollars per case). It also adds to the frustration of the parties involved, and thus, is counterproductive.

Therefore, it is recommended that fact-finding for the protective services be instituted only when the ERB deems it is in the public interest, or when both parties voluntarily, and mutually, request such services. In my opinion, such 
be potentially successful, would work with experienced factfinders that have a reputation for their expertise in the field. Because fact-finding involves many skills that cannot be totally learned from a book, an apprenticeship would smooth the rough edges, just as a student teacher learns the "tricks of the trade" from a master teacher, so would an apprentice fact-finder learn from a master fact-finder. Post-Entry Inservice Training. It is recommended that the state Conciliation Service continue and expand its efforts to update and train present fact-finders in the areas of writing format, use of consistent criteria of judgment, other fact-finders' finding, and fact-finding techniques. The purpose of such training would be to cultivate consistency throughout the process, from the hearing to the written reports. Such training could occur in workshop form several times a year, and attendance of a certain amount required in order for a fact-finder to remain on the list.

(2) Evaluation of Fact-Finders. It is recommended that some type of a formal evaluation system be developed by the State Conciliation Service in order to become aware of any consistent problems the parties may be having with particular fact-finders. Presently the parties have no formal way of sharing their "fact-finder" problems and only learn by trial and error; this is not too effective and imposes great costs of the parties, and indeed, the public. It also reduces confidence in the system. The proposed evaluation would give ERB administration a relatively fast 
and objective way to help improve the quality of factfinders and the level of confidence the parties have in the service.

(3) The Fact-Finder List and Fees. It is recommended that the State Conciliation Service's fact-finders' list reflect the fees of all fact-finders on that list. Furthermore, it is recommended that fact-finders be required to submit a written notice to the service 60 days prior to a change in fees; and be prevented from changing the fees after the selection process. This would allow the service to update the list prior to any selection, and protect the parties from unanticipated fee changes.

\section{Issuance of the Report}

It is recommended that the State Conciliation Service take serious action to encourage fact-finders to issue their reports within the thirty day period as required by law. Obviously, some situations, such as cases requiring posthearing briefs, warrant as much as a two week extension. However, as the aggregate data indicated, over 60 percent of the reports take over one month to be issued, and of that over 20 percent take over six weeks, which, except for extraordinary circumstances, is far too long. It does not seem unreasonable that the ERB enforce the thirty day limit to a practical degree given the law, the high fees parties pay, and the frustrations caused by excessive time lapses. 


\section{Parties' Actions on Reports}

It is recommended that the $\mathrm{ERB}$ require parties to either accept or reject a report within the five day period as proscribed by law. It is also recommended that the parties be required to take action on an issue by issue basis, rather than on the total report.

In the first instance, ERB would merely be helping to enforce the law, with the side effects of being able to release to the press the fact-finders' report for publication. The aggregate data showed employee groups were involved in no action in 28 percent, and employers in 13 percent of the cases going to hearing. Presently, in cases where one party accepts and one takes no action, ERB cannot release the report for publication, thus relieving the parties of potential public pressure.

In the second instance, if parties were required to take action on an issue by issue basis, it would allow them to immediately determine the areas of agreement, narrow any unresolved issues, and identify the major issues. Furthermore, this would make it easier for both parties and neutrals to formally and consciously see the usefulness of fact-finding reports, and could further any super-mediation efforts.

\section{Publication of Reports}

It is recommended that the ERB release fact-finding reports to the local hometown newspapers in order to encourage 
the intent of the law and the philosophy behind publication of the report. The parties indicated in the interviews that publication of the report does not, in their view, serve to encourage impasse resolution to a significant degree. However, considering that as many as 28 percent of the reports are not published due to no action by parties, and considering that ERB releases the reports to the wire service, not the local papers, it is difficult to tell to what extent publication might encourage resolution. It is realized that publication still may not serve its intended purpose. However, such action by ERB would, at least, result in the public having the opportunity to become aware and express their opinions concerning a particular case.

\section{Fact-Finders' Fees}

It is recommended that consideration be given to a state-wide fee system. The reasons for such consideration are two-fold. First, the interviews showed that many of the parties, particularly the unions, were concerned about the high fees that fact-finders charge. High fees are a particular burden to smaller units and the unions (who pay from dues), and much less so for the public employer who derives its income from taxes. Second, because the parties are obligated to use the process under law, there is justification to not allow the unrestrained market to set the price. This is especially so where demand is excessive (due to government requirements) and supply limited (and not encouraged 
by government aid).

Related to this are the unusual circumstances where parties have refused to pay a fact-finder for one reason or another. Perhaps the ERB should consider a partial prepayment system as well to relieve this problem.

Again, it was also recommended that fact-finders be required to give the State Conciliation Service a 60 day notice of any fee change. This would allow the Service to update the list with regard to any change in fact-finder fees prior to the selection process. Furthermore, it is recommended that once selected, the fact-finder could not charge a fee greater than that reflected on the list provided to the parties involved.

Scope of Bargaining

It is recommended that the FRB make some decision regarding the discretion of fact-finders in order to add consistency in hearings and reports. Both neutrals and parties have indicated that a major problem in the fact-finding process is the uncertainty on what are permissive and mandatory issues, and whether a fact-finder will hear and/or make recommendations on such issues. It is realized that such action might place further burdens on the ERB. However, only ERB, and not the fact-finders, are equipped to deal with such problems.

\section{Attitudes}

It is recommended that ERB conduct workshops to social- 
ize or educate the parties in the overall concepts and philosophy underlying collective bargaining and impasse resolution under Oregon law. These workshops would include both parties and be held on neutral territory such as university and/or community college campuses. They would be conducted by recognized and qualified experts in public section labor relations.

The reasoning behind such a recommendation is that the aggregate data and the interviews indicate the parties' attitudes (in particular public school employers) are anticollective bargaining; these attitudes subvert the intent of negotiations and thus the fact-finding process. Many suggest that time and experience will take care of some of these problems; however, it is suggested here that an effort by $\mathrm{ERB}$ to help educate and socialize the parties is appropriate. The parties need to be reminded about the positive aspects of Oregon law, its intent, and philosophy. Workshops such as these would certainly not hurt, and could prove very beneficial to the parties' use of the process, and the public interest.

\section{Budget Deadlines}

It is recommended that the legislature enact some type of negotiations-impasse deadline in order that fact-finding coes not run past budget deadines. The interviews indicated that a major problem with fact-finding is that it takes many cases past budget deadlines, thus making it 
difficult to institute the agreement into the budget. A deadine would force parties to bargain earlier and finish the process before the budget was due. This could be accomplished by any of the following ways:

(1) Copy the old meet-and-confer law; that is, factfinding would have to be finished by, say, March or April, thus the parties are obliged to bargain earlier (say late fall) in order to finish by the June budget deadline. The advantages are that bargaining would be tied to the budget period, adding some fiscal sense to the situation (if employers have to guess what to allocate employees in their budget they have essentially determined their top line before conclusion of negotiations). Presently, the factfinders' recommendations may not be feasible without a special election. Also such a deadline encourages both parties to get to the nitty-gritty and to not stall; that is, it would encourage more serious bargaining during negotiations.

(2) Change the fiscal year for schools (where most of the problems exist) from July 1 - June 31, to September 1 August 31 . This has proven reasonably successful in the State of Washington, where even if bargaining begins late, say March, the parties have all summer to finish factfinding and sign a contract. Of course if labor decides to strike it would be much less effective in mid summer than near the end of a term. Such a change would also spread out the burden on the Conciliation Service and on fact- 
finders, as all public employees are now on a July 1 - June 31 fiscal year and under this proposal they would be staggered (education september 1 - August 31, all others July 1 - June 31).

\section{Summary}

In summary, these recommendations are intended to reduce the severity of many of the problems with Oregon's fact-finding process. Fact-finding for most public sector impasse cases has more positive than negative aspects, and provided the problems are alleviated, the process can go a long way toward accomplishment of its purported goal.

\section{AREAS FOR FUTURE RESEARCH}

The aggregate data and interviews generated certain questions to which future research could be guided with interesting and potentially useful results. First, the aggregate data suggested that employer actions on fact-finders' reports are associated with the employee organization involved. Further research might address the question whether this is a result of tradition, personalities of the actors, or other variables. Such research might prove very useful in future understanding of public employee labor relations on a national scale. Second, research might be conducted that measured parties' attitudes in relation to time lapse. This could give the legislature an idea of how to build realistic time deadines. Third, more research could be 
directed to the relationship between exogenous factors (such as population, unemployment, etc.) of the areas involved and the parties' actions on fact-finder reports. Fourth, and of particular interest, would be research into what attributes the parties consider important for a successful fact-finder, and furthermore if the parties really want fact-finders to recommend what they consider fair, rather than acceptable. Fifth, research is needed in the general area of the collective bargain model, to direct the employer-employee relationship in more positive directions.

THE FUTURE

This study has shown that fact-finding in oregon is successful in reducing impasses and thus the potential number of strikes. This has also shown that the process is more successful than not in reducing the issues causing impasse, educating or socializing the parties in the collective bargaining process, and encouraging good faith bargaining. Because of its effectiveness it is recommended the process be refined rather than abolished. The problems, however, are numerous and serious. Some of the problems can be alleviated by instituting recommendations like those presented in this study; others will take dramatic institutional changes before they are significantly reduced.

I specifically refer to the attitudes of the parties in an adversary collective bargaining model such as that which exists in U. S. labor relations. The best impasse resolu- 
tion procedure will not be successful unless the parties bargain in good faith. In order to bargain in good faith, the parties have to be socialized toward a common goal and commitment that is beyond their immediate self interest (for example, "good" education). Furthermore, the administrators of public services have to reflect a common commitment by including all persons, to some degree, in the decision-making process. What is being suggested here is that participatory, or democratic management, is a vehicle through which labor problems can be avoided in the first place, and common goals reached.

The real problem with Oregon's fact-finding process is the problem with most aspects of U. S. labor relations: a lack of sense of control and fair play by one or both parties. It is to this end that future efforts might prove invaluable. 
SOURCES CONSULTED

BOOKS

Beal, Edwin F., Edward Wickersham, and Philip K. Kienast. The Practice of Collective Bargaining. Homewood, Ill.: Irwin, 1976 .

Bennis, Warren G., and Philip E. Slater. The Temporary Society. New York: Harper, 1968.

Blalock, Jr., Hubert M., and Ann B. Blalock. Methodology in Social Research. New York: McGraw-Hill, 1968 .

Blalock, Jr., Hubert M. An Introduction to Social Research. Englewood Cliffs, N.J.: Prentice-Hall, 1970 .

-.---. Social Statistics. 2nd ed. New York: McGrawHill, 1972 .

Cambell, Donald T., Richard D. Schwartz, and Lee Sechrest. Unobstrusive Measures. Chicago: Rand McNally, 1971.

Caraley, Demetrios. City Governments and Urban Problems. Englewood Cliffs, N.J.: Prentice-Hall, 1977.

Dexter, Lewis Anthony. Elite and Specialized Interviewing. Evanston: Northwestern Univ. Press, 1970.

Elkouri, Frank, and Edner Asper Elkouri. How Arbitration Works. 3rd ed. Washington, D.C.: Bureau of National Affairs, 1973.

Freeman, Howard F., and Clarence C. Sherwood. Social Research and Social Policy. Englewood Cliffs, N.J.: Prentice-Hall, 1970 .

Galbraith, John Kenneth. The New Industrial State. Boston: Houghton Mifflin, $196 \overline{7 .}$

Economics and the Public Purpose. Boston: Houghton Mifflin, 1973.

Gallagher, James. Impasse Resolution in Public Sector Disputes. Los Angeles: Institute of Industrial Relations, Univ. of California, 1976. 
Hagburg: Eugene $\mathrm{C}$, and Marvin J. Levine. Labor Relations: An Integrated Perspective. St. Paul: West, 1978 .

Hildebrand, George. "The Public Sector." In Frontiers of Collective Bargaining. Ed. John Dunlop and Neil

Chamberlain. New York: Harper, 1967, pp. 147-52.

Huges, Charles L. Making Unions Unnecessary. New York: Executive Enterprises, 1976.

Jascourt, Hugh D. Public Sector Labor Relations: Recent Trends and Developments. Lexington, Ky.: Council of State Governments and International Personnel Management Assn., 1975.

Jones, E. Terrence. Conducting Political Research. New York: Harper-Row, 1971 .

Jones, Ralph T. Public Sector Labor Relations: An Evaluation of Policy-Related Research. Belmont, Mass.: Contract Research Corp., 1975.

Kreps, Juanita M., Gerald G. Somers, and Richard Perlman. Contemporary Labor Economics: Issues, Analysis, ind Policies. Belmont, Ca.: Wadsworth, 1974 .

Moskow, Michael H., Joseph J. Loewenberg, and Edward Clifford Koziara. Collective Bargaining in Public Employment. New York: Random House, 1970.

Prentice-Hall Editorial Staff and International Personnel Management Association. "Impasse Techniques Survey." In Public Personnel Administration/Labor Management Relations. Vol. I. Englewood Cliffs: Prentice-Hall, 1974, Pp. $3139-48$.

Pugh, D. S., et al. Organization Theory. Ed. D. S. Pugh. Baltimore: Penguin, 1971, pp. 213-69.

Reynolds, Lloyd G. Labor Economics and Labor Relations. Englewood Cliffs, N.J.: Prentice-Hall, 1959.

Schneider, B. V. H. "Collective Bargaining and the Federal Civil Service." In Collective Negotiation for Public for Public and Professional Employees. Ed. Robert T. Woodworth, and Richard B. Peterson. Glenview, Il1.: Scott-Foresman, 1969 .

Schoen, Sterling $H$. and Raymond $L$. Hilgert. Cases in Collective Bargaining and Industrial Relations: A Decisional. Approach. 3rd ed. Homewood, Ill.: Irwin, 1978. 
Selltiz, Claire, Marie Jahoda, Morton Deutsch, and Stuart W. Cook. Research Methods in Social Relations. New York: Holt, $1 \overline{964}$.

Simkin, William. Mediation and the Dynamics of Collective Bargaining. Washington, D.C.: Bureau of National Affairs, 1971.

Spero, Sterling, and John M. Capozzola. The Urban Community and its Unionized Bureaucracies. New York: Dunellen, 1973 .

Walsh, Robert E. Sorry ... No Government Today, Unions vs. City Hall. Boston: Beacon, 1969 .

Weisberg, Herbert F., and Bruce D. Bowen. An Introduction to Survey Research and Data Analysis. San Francisco: Freeman, 1977 .

Wellington, Harry H., and Ralph K. Winter, Jr. The Unions and the Cities. Washington, D.C.: The Brookings Institution, 1971 .

Yaffe, Byron, and Howard Goldblatt. Factfinding in Public Employment Disputcs in New York State: More Promise Than Illusion. Ithaca: School of Industrial Relations, Cornel1 Univ., 1971.

Zack, Arnold M. "Impasses, Strikes, and Resolutions." In Public Workers and Public Unions. Ed. Sam Zagoria. Englewood Cliffs, N.J.: Prentice-Hall, 1972, pp. $101-21$.

\section{ARTICLES}

Anderson, Arvid. "Strikes and Impasse Resolution in Public Employment." Michigan Law Review, 67 (1969), 943-970.

------. "Public Employees and Collective Bargaining: The Changing of The Establishment." Wake Forest Law Review, 7 (1971), 175-188.

Bernstein, Merton C. "Alternatives to the Strike in Public Labor Relations." Harvard Law Review, 85 (1971), 459-475.

Burton, John F. Jr. "Can Public Employees Be Given The Right To Strike?" Labor Law Journal, 21 (1970), 472478 . 
Cole, David. "The Search for Industrial Peace." Monthly Labor Review, 96, No. $9(1973), 38$.

Davey, Harold $w$. "The Use of Neutrals in the Public Sector." Labor Law Journal, 20 (1969), 529-538.

Doherty, Robert E. "Factfinding: A One-Eyed Man Lost Among the Eagles." Public Personnel Management, 5, No. 5 $(1976), 363-36 \overline{7}$.

Drothning, John E. and David B. Lipsky. "The Outcome of Impasse Procedures in New York Schools Under the Taylor Law." The Arbitration Journal, 26 (1971), 87-102.

Feuille, Peter. "Final-offer Arbitration and Negotiating Incentives." The Arbitration Journal, 32, No. 3 (1977), 203-220.

Flango, Victor $\mathrm{E} .$, and Robert Dudley. "Who Supports Public Employee Strikes?" Journal of Collective Negotiations, $7,(1978), 1-9$.

Fowler, Robert Booth. "Normative Aspects of Public Employee Strikes." Public Personnel Management, 3, No. 2 $(1974), 130-138$.

Gilroy, Thomas P., and Anthony V. Sincropi. "Impasse Resolution in Public Employment: A Current Assessment." Industrial and Labor Relations Review, 25 , No. 4 (1972), 496-511.

Gould, William B. "Public Employment: Mediation, Fact Finding and Arbitration." American Bar Association Journal, $55(1969), 835-840$.

Grodin, Joseph, and Mark Hardin. "Public Employee Bargaining in Oregon." Oregon Law Review, 51 (1971), 7-68.

Harrison, Jr., Damon W. "The Strike and Its Alternatives: The Public Employment Experience." Kentucky Law Journal, $65(1975), 430-465$.

Howlett, Robert G. "Contract Negotiation Arbitration in the Public Sector." University of Cincinnati Law Review, 42 , No. 1 (1973), $47-75$.

Jossen, Robert J. "Fact-Finding: Is it Adjudication or Adjustment." The Arbitration Journal, 24 (1969), 106-115. 
Kagel, Sam, and John Kagel. "Using Two New Arbitration Techniques." Monthly Labor Review, 95, No. 11 (1972), $11-14$.

Kheel, Theodore W. "Strikes and Public Employment." Michigan Law Review, 67 (1969), 931-942.

- "Exploring Alternatives to the Strike." Special Section. Monthly Labor Review, 96, No. 9 $(1973), 33-66$.

Mckelvey, Jean T. "Fact-Finding in Public Employment Disputes: Promise or Illusion?" Industrial and Labor Relations Review, 22 , No. 4 (19 $\overline{69), ~ 528-543 .}$

Overton, Craig E., and Max S. Wortman. "One More Time: What is Collective Bargaining in the Public sector All About?" Journal of Collective Negotiations, $5(1976), 3-1 \overline{3}$.

Rains, Harry H. "Dispute Settlement in the Public Sector." Buffalo Law Review, 19 (1969), 279-287.

Rehmus, Charles M. "Is a 'Final Offer' Ever Final?" Monthly Labor Review, 97 (1974), 43-45.

Seamon, Harold Palmer, Jr. "Fact-Finding in the Public Sector: A Proposal to Strengthen the Fact-Finders' Role." Journal of Collective Negotiations in the Public sector, $3(1974), 121-132$.

Somers, Paul. "An Evaluation of Final-Offer Arbitration in Massachusetts." Journal of Collective Negotiations, 6 , No. 3 (1977), 193-210.

Steiber, Jack, and Benjamin W. Wolkinson. "Fact-Finding Viewed by Fact-Finders: The Michigan Experience." Labor Law Journal, 28, No. 2 (1977), 89-101.

Taylor, George W. "Public Employment: Strikes or Procedures?" Industrial and Labor Relations Review, 20

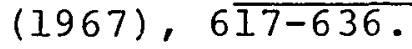

Weisenfeld, Alan. "Public Employees are Still Second Class Citizens." Labor Law Journal, 20 (1969), 138-150.

Wolkinson, Benjamin W., and Jack Stieber. "Michigan FactFinding Experience in Public Sector Disputes." The Arbitration Journal, 31 (1976), 225-247.

Word, William R. "Fact Finding in Public Employee Negotiations." Monthly Labor Review, 95 (1972), 60-64. 
Zack, Arnold M. "Improving Mediation and Fact-Finding in the Public Sector." Labor Law Journal, 30 (1970), 259-273.

Zagoria, Sam "Resolving Impasses by Public Referendum." Monthly Labor Review, 96, No. 6 (1973), 36-38.

\section{CONFERENCE PROCEEDINGS}

Cleveland, Melvin H. "Public Sector Labor Relations Legislation In Oregon." Proc. of the Twelfth Labor Management Conference on Collective Bargaining And Labor Law. January 1976. Tucson, Ariz.: Univ. of Arizona, 1976.

Finkelman, Jacob. "Fact Finding: Its Values and Limitations: Comment." Arbitration and the Expanding Role of Neutrals. Proc. of the Twenty-Third Annual Meeting, National ACademy of Arbitrators, Washington, D.C.: Bureau of National Affairs, 1971, pp. 183-186.

Hill, James. "The Presidential Address." Arbitration and the Expanding Role of Neutrals. Proc. of the TwentyThird Annual Meeting, National Academy of Arbitrators. Washington, D.C.: Bureau of National Affairs, 1971, pp. 187-207.

Howlett, Robert G. "Fact Finding: Its Values and Limitations: Comment." Arbitration and the Expanding Role of Neutrals. Proc. of the Twenty-Third Annual Meeting, National Academy of Arbitrators. Washington, D.C.: Bureau of National Affairs, 1971, pp. 175-186.

Huettner, David A., and Thomas Watkins. "Public Sector Bargaining: An Investigation of Possible Environmental Differences." Proc. of the Twenty-Sixth Annual Meeting of the Industrial Relations Research Association, 1973. Madison: Industrial Relations Research Association, 1973, pp. 178-181.

Simkin, William E. "Fact Finding: Its Values and Limitations." Arbitration and the Expanding Role of Neutrals. Proc. of the Twenty-Third Annual Meeting, National Academy of Arbitrators. Washington, D.C.: Bureau of National Affairs, 1971, pp. 165-174.

Wurf, Jerry. "The Uses of Fact-Finding in Public Employee Dispute Settlement: The Union View." Arbitration and Social Change. Proc. of the Twenty-Second Annual Meeting, National Academy of Arbitrators. Washington, D.C.: Bureau of National Affairs, 1970, pp. 95-107. 


\section{INFORMATION SERVICES}

Bornstein, Tim. Facts About Fact-Finding. Strengthening Local Government Through Better Labor Relations. Report No. 8. Washington, D.C.: Labor-Management Relations Service, 1971 .

Drachman, Allan W. Municipal Negotiations: From Differences to Agreement. Strengthening Local Government Through Better Labor Relations. Report No. 5. Washington, D.C.: Labor Management Relations Service, 1970.

Executive Order 11491. "Labor Management Relations in the Public Sector." Government Employee Relations Report. Washington, D.C.: Bureau of National Affairs, 1969 .

Foundation for Oregon Research and Education. Collective Bargaining and Tenure in Oregon Education. Portland, Ore.: Foundation for Oregon Research and Education, 1977.

Howlett, Robert G. "Some Observations on Neutrals." In The Role of the Neutral in Public Sector Disputes. Ed. Howard J. Anderson. Washington, D.C.: Bureau of $\mathrm{Na}-$ tional Affairs, 1972, pp. 60-68.

Oregon School Boards Association. Impasse Resolution Techniques: Mediation and Fact-Finding. Salem, Ore.: Oregon School Boards Association, 1971.

Sharkey, Jr., Samuel M. Public Employee Strikes: Causes and Effects. Strengthening Local Government Tlirough Better labor Relations. Report No. 7. Washington, D.C.: Labor Management Relations Service, 1970.

Wesley, Roy. Impasse Resolution: An Analysis of old and New Ways to End Deadlocks. Washington, D.C.: Labor Management Relations Service, 1976.

Wetherall, Shannon. "Scope of Collective Bargaininu in Education." Tips and Trends - Special Roport. (1) y.tis, Wash.: Washington State School Directors Assouition, 1976 .

Wollett, Donad H. "Some Facts and Fantasies About Publi. Employee Bargaining." In The Role of the Neutral in Public Employee Disputes. Ed. Howard J. Anderson. Washington, D.C.: Bureau of National Affairs, 1972, pp. 69-101. 


\section{GOVERNMENT PUBLICATIONS}

Gilroy, Thomas P., and Anthony V. Sincropi. Dispute Settlement in the Public Sector: The State-of-the-Art. Washington, D.C.: GPO, 1972 .

Governors Task Force on Collective Bargaining in the Public Sector. Testimony to the House Committee on Labor and Industrial Relations. 31 January 1973.

Governors Task Force on Collective Bargaining in the Public Sector. Testimony to the Senate Committee on Labor and Industrial Relations. 31 May 1973.

Oregon Legislative Assembly. Report of the Joint Interim Committee on Labor and Commerce. 59th Oregon Legis lative Assembly, December 1976.

U. S. Bureau of the Census. Labor Management Relations in State and Local Governments: 1976. Washington, D.C.: GPO, 1978 .

U. S. Bureau of the Census. Public Employment in 1977. Washington, D.C.: GPO, 1978 .

U. S. Dept. of Commerce. News. CB 78-100. Washington, D.C.: GPO, 1978 .

U. S. Dept. of Labor. Summary of Public Sector Labor Relations Policies. Washington, D.C.: GPO, 1976.

\section{UNPUBLISHED MATERIALS}

Krinsky, Edward B. "An Analysis of Fact-Finding as a Procedure for the Settlement of Labor Disputes Involving Public Employees." Diss. Univ. of Wisconsin 1969.

Rawlings, Lloyd Arthur. "A Field Study of Oregon's Factfinding Procedure." Thesis. Univ. of Oregon 1977.

Seamon, Harold Palmer Jr. "Fact Finding in the Resolution of Teacher Organization - School Board Impasse During Collective Negotiations, Particular Reference to New York State." Diss. Columbia Univ. 1969. 
PERSONAL AND TELEPHONE INTERVIEWS, AND PERSONAL LETTERS Brown, Ken. Letter to author. 2 February 1979. Cleveland, Melvin H. Telephone interview. 26 February 1979. Edwards, Roy. Telephone interview. 26 February 1979. Kleinsorg, Paul. Telephone interview. 19 June 1978. Redden, James. Personal interview. 13 June 1978. Schurke, Marvin. Letter to author. 6 october 1978. Smith, Leroy. Personal interview. 25 July 1978. Stewart, Don. Telephone interview. 11 April 1978.

\section{LEGAL REFERENCES}

Ore. Const. Art. VI, sec. 10.

Ore. Const. Art. IX, sec. 2 .

Or. Laws Ch. 80 (1969).

Or. Laws Ch. 390 (1965).

Or. Laws Ch. 543, secs. 2-4 (1965).

Or. Laws Ch. 579 (1963).

Oregon Revised Statutes, sec. 240.060 (1977).

Oregon Revised Statutes, secs. 243.650-243.782 (1977).

Oregon State Employment Relations Board, Case Nos. C-278, $\mathrm{C}-279, \mathrm{C}-280$, and $\mathrm{C}-344$.

Oregon Supreme Court Reports, Advanced Sheets, 78, No. 4 (Feb. 21, 1978), p. 156.

Postal Reorganization Act of 1970. Public Law No. 91-375, 84 Stat. 719, Sec. 228 (b) and (c). 


\section{APPENDIX A}

METHODOLOGICAL NOTES

Multiple operationism is employed in this dissertation in that different methods of data collection are used. According to Cambell, et al. the value of this procedure is that "it diminishes the slippage between the conceptual and operative specifications," because more than one method of measurement is utilized.

The procedures used and related problems involved in the general aggregate data and the elite or authoritative survey are discussed as follows.

I. General Aggregate Data. The general aggregate data provide thefirst accurate and comprehensive data base available in Oregon from which to describe and analyze this state's fact-finding process. It also provides a starting point for exploration of the possible association between variables and the generation testable hypotheses.

The data was produced from the files of the Oregon State Conciliation Service and the population of 239 cases that occurred from 1974 through 1977. Data were analyzed with the Statistical Program for the Social Sciences (SPSS). The 19 variables involved are: 
(1) Year. This variable provided information as to the frequency and rate of change in fact-finding cases from 1974 through 1975.

(2) Fact-Finder. This information allowed identification of those fact-finders most involved in the process, which was useful in determining who to interview. Also it was possible to compare the fact-finder and the parties' actions on their reports in order to find whether any association exists. It proved very valuable in terms of suggesting directions for future research and substantiating some of the parties' concerns.

(3) Type. This variable measured possible differences between the education and the non-education sectors. (4) and (5) Employee Organization and Employer. These variables provided data on unions and governmental participation and actions in each phase of the process. Cross tabulations were used to determine possible associations between actors and other variables.

(6) Home Rule Status. Because the home rule issue caused confusion and inconsistant use of the process it was dropped from the aggregate data. This variable accounts for the major source of missing data.

(7) Settled-Before Hearing. This variable was used to isolate those cases where a request for fact-finding occurred but where the parties settled prior to a hearing. It provided a means to compare the participants' actions in this phase and provided information 
that led to insights as to the filtering concept of the impasse process.

(8) and (9) Employee and Employer Actions. These variables refer to the parties' action taken on the factfinding report. Three actions were possible: accept, reject, and no action. This provided frequency distributions and allowed for cross tabulations between action and employee and employer categories. This was paramount in describing the effectiveness of the process and pointing to the direction of further questioning and problems.

(10) and (11) Time Request to Hearing, and Hearing to Report. These variables provided measurement of the time involved in the process. There were four time categories: 0-4 weeks, 4-6 weeks, 6-8 weeks, and over 8 weeks. This provided information relating to the time schedule required by the law, and allowed for cross tabulations between time and the parties' actions. The data generated wert interesting, and useful in that many other questions arose from that data. In future research it will be more useful to measure time in days rather than intervals. This would allow averages to be obtained and more rigorous statistical analysis to be applied.

(12) Reports Published. This variable is important because of the idea that publishing the report will put pressure on the parties to settle. Unfortunately, 
the lack of consistent record keeping made this variable so unreliable that it was not utilized in the analysis. But in the process of attempting to collect this data, important weaknesses in the process were sighted. These weaknesses were the way it was published, and the parties' use of no action as a way to avoid publication.

(13) Strike Notice. This variable was used to generate the frequency of strike notices as required under Oregon law.

(14) and (15) Settled With and Without Mediation. These variables allowed identification of those cases where reports were rejected and super-mediation was required, as opposed to those cases where the parties settled themselves without further assistance by a neutral third party. It proved valuable in recognizing super-mediation as a very important step in the impasse process.

(16) Arbjtrated. This provided the frequency of cases going to arbitration and added information on the filtering concept of the impasse process. It also allowed an understanding of the usefulness of fact-finding when it is integrated with binding arbitration.

(17) strike. The purpose of the impasse process is to prevent public sector strikes. This variable was useful in generating the frequency of strikes among various sectors and the percentage of cases going to fact- 
finding that went on to strike.

(18) and (19) Population and Census Type. These variables were utilized to gain information on the relation of cases and action to population and census type. The population categories were: under 2,$500 ; 2,500$ 10,$000 ; 10,000-50,000 ;$ and over 50,000. The census type definitions were based upon Bureau of Census definitions. They are: rural (under 2,500); suburban (contiguous to a central city, incorporated, larger than 2,500 -- in the "urban fringe"); and urban (over 2,500 and not suburban). These variables allowed some description and analysis as to where most fact-finding cases occurred, and allowed cross tabulations with parties' actions.

Problems with the Aggregate Data. Some data were missing because not all fact-finding records are complete. However, much of the missing data on records was compensated for through interviews of key people at the service. Information not recalled by them was reported as missing. Most of the missing data involved home rule cities and counties; thus the reason for dropping them the analysis. This meant that although generalizations about the factfinding process could be done, analysis pertaining to home rule cities and counties was not possible.

II. Elite or Authoritative Survey. This type of survey provided a systematic basis (for the first time in oregon) to 
obtain and evaluate the views of representatives from all four categories of participants involved in Oregon's factfinding process -- mediators, fact-finders, unions, and government employers.

In using the elite survey method it is assumed that all persons and/or categories of experts are not equally important, and that some have more insight into the process and much more impact on policy formation than others. $b$

The data were collected through a questionnaire administered in a personal interview situation. This format allowed for candor and higher response rates compared to a mail or phone interview format. ${ }^{\mathrm{C}}$ Respondents were guaranteed complete anonymity.

A scaling technique was employed to allow the parties to express full intensity of their feelings and provide for more in-depth analysis. The scale was intentially designed to prevent the parties from taking a neutral stand, thus forcing them to scale their level of agreement or disagreement. Most of the questions were closed-ended.

The personal interview situation allowed parties to explain the reasons they felt as they did, and to provide additional information beyond their choice on the scale -thus, giving the analysis a frame-work of measured opinions about which further interpretation could occur given the comments during the interviews.

The length of the questionnaire was designed so the interview would take between 30-45 minutes. As a result, 
the questions were limited to those perceived to be most important.

A non-random sampling technique was employed and those interviewed were selected on the basis of information provided in the aggregate data and discussion with practitioners in the field.

The subsamples were as follows: Fact-finders -- ten were interviewed and these ten account for over 64 percent of the total fact-finding cases going to hearing. Mediators -- nine were interviewed and they account for 95 percent of all non-home rule fact-finding cases requiring post-factfinding m-diation. Employees -- representatives of five unions were interviewed; these five unions account for over 80 percent of the total non-home rule fact-finding cases going to hearing. It was assumed the state level of these unions represent the general views of the locals and also formulate general union policy. Employers -- ten were interviewed; seven from the education sector (which accounts for 70 percent of all non-home rule fact-finding cases go-ing to hearing), and three others representing state, county and municipal, and special district units of government; thus all major types of governments were represented. This technique made it possible to interview those who are in especially good positions to supply information; and share useful insights. However, it does not provide an adequate enough base from which to test for statistical significance. Generalizations derived from the interviews about 
the fact-finding process are made based upon the author's judgement and the known facts about the subsample described above. $^{d}$ one important advantage of the survey was the provisions of information that the aggregate statistics could not show, and the revelation of many problems and benefits of the process that could not be found by the aggregate analysis or a mailed questionnare.

In doing further research it would be useful to design the questionnaire so that each category was answering the same questions. In this study this could not be accomplished because there was no data base from which to work, and the time for interviews had to be limited.

a Donald T. Cambell, Richard D. Schwartz, and Lee Sechrest, Unobtrusive Measures (Chicago: Rand McNally, 1971), pp. 1-34.

$\mathrm{b}_{\text {Lewis }} \mathrm{A}$. Dexter, Elite and Specialized Interviewing (Evanston, Ill.: Northwestern Univ. Press, 1970), pp. 7-8.

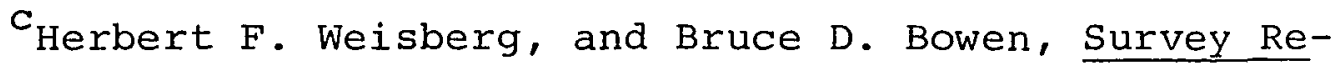
search and Data Analysis (San Francisco: Freeman, 1977), p. 59 .

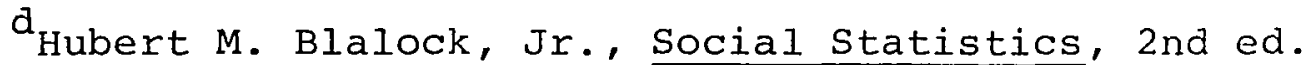
(New York: McGraw-Hill, 1972), p. 528 . 


\section{APPENDIX B \\ SUPPORT INFORMATION ON INTERVIEWS}

The following may be found in this appendix:

Title Page

List of Neutrals Interviewed . . . . . . . . 295

List of Parties Interviewed . . . . . . . . 296

Questionnaire for Mediators . . . . . . . . 298

Questionnaire for Fact-Finders . . . . . . . 300

Questionnaire for Parties . . . . . . . . 302

Neutrals' Ranking of Reasons

That Cause Fact-Finding . . . . . . . . 304

Parties' Ranking of Reasons

That Cause Fact-Finding . . . . . . . . . 305 
LIST OF NEUTRALS INTERVIEWED

Mediators

1. John Abernathy

2. Lowell Ashbaugh

3. Robert Bell

4. Ken Brown

5. Hugh Lovell

6. Robert Hipps

7. Kathy Mistler

8. Alton Smedstad

9. John Vale

Fact-Finders

1. John Abernathy

2. William Hammond

3. Lafayette Harter

4. Hugh Lovell

5. R. W. Nahstoll

6. Leroy Smith

7. Carlton Snow

8. Roger Tilbury

9. Timothy D. Williams

10. Ron Loew 
LIST OF PARTIES INTERVIEWED

Government Employer Representatives

1. Andrew Alexander, Director of Employee Relations, Beaverton School District, \#15

2. John Bodilly, Negotiator, Medford Area

3. Michael Cunningham, Employee Relations Manager, Port of Portland

4. Jerry Martin, Director of Field Service and Labor Relations, Oregon School Boards Association

5. Richard Miller, Attorney, Negotiator, Springfield, Eugene Area

6. Lon Mills, President, Mills and Associates, Inc., Negotiators, Eugene Area

7. Bryan Mullen, Attorney, Negotiator, Medford Area

8. Edward P. Rosenlund, Supervisor, Employee Relations, Personnel Division, State of Oregon

9. H. Kenneth Zinger, Attorney, Negotiator, Hillsboro Area

10. Donald W. Scott, Labor Consultant, Local Government Personnel Institute

Public Employee Labor Organization Representatives

1. Robert Crumpton, Executive Secretary, Oregon Education Association (OEA)

2. Roy Dancer, OEA Uniserve Consultant, Clackamas

3. Jerry Dodge, American Federation of Teachers

4. Robert Ellis, Field Representative, Oregon School Employees Association

5. William Greer, Jr., Attorney, represents public sector labor organizations

6. Dick Hoit, Executive Director, American Federation of State, County and Municipal Employees

7. Charlene Sherwood, Attorney, Oregon State Employees Association

8. Steve Straugham, OEA Uniserve Consultant, Medford 
Others

1. Melvin Cleveland, Chairperson, Employment Relations Board, State of Oregon

2. Roy Edwards, Senior Hearings Officer, Employment Relations Board, State of Oregon

3. Jorge Haynes, Program Analyst, Public Employment Relations Board, State of California

4. Dr. Paul Kleinsorge, Professor of Economics, University of Oregon

5. John P. McCarthy, Presiding Conciliator, California State Conciliation Service, State of California

6. Karen Norton, Public Employment Relations Reporter, Califorria Research, Inc.

7. James Redden, Attorney General, State of Oregon

8. Marvin L. Schurke, Executive Director, Public Employment Relations Commission, State of Washington 
QUESTIONNAIRE FOR MEDIATORS

The purpose of this research is to study the factfinding process. The intent of Oregon's impasse procedure is to act as a filtering process where each step reduces the number of impasses and brings the parties closer to resolution, thus encouraging good faith bargaining and reducing possible strikes.

Please respond to the following questions. If you have any additional comments or explanations you may wish to make, they would be appreciated; you may use the back of this sheet for that purpose.

1. Generally, have you been the mediator before and after factfinding?

2. Rank the five most important reasons that cause factfinding.

1.

$4 \cdot$

3. Why are so many cases settled after rejection of the report, but before strike?
2.

5.
3.

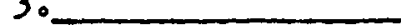

Rate the followling statements acording to the scale at the right. Mark your responses in the space provided.

$$
\begin{array}{c|c|c|c|c|c|c|}
\substack{n / a \\
\text { no } \\
\text { opinion }} & \begin{array}{c}
-3 \\
\text { strongly } \\
\text { disagree }
\end{array} & \begin{array}{c}
-2 \\
\text { disagree }
\end{array} & \begin{array}{c}
-1 \\
\text { somewhat } \\
\text { disagree }
\end{array} & \begin{array}{c}
+1 \\
\text { somewhat } \\
\text { agree }
\end{array} & \begin{array}{c}
+2 \\
\text { agree }
\end{array} & \begin{array}{c}
+3 \\
\text { strungly } \\
\text { agree }
\end{array} \\
\hline
\end{array}
$$

4. The part1es generally engage in good faith bargaining through mediation and factfinding.

5. Factfinding significantly reduces issues causing impasse.

6. Factfinders are a positive factor in impasse resolution. 
7. The factfinders are innovative in their recommendations.

8. Factrinding causes parties to hold back offers in mediation.

9. Factfinding is a tool for negotiation strategy. (If so, in what way?)

10. The factfinder's report is the basis for post-factfinding settlement.

11. One party is more prone to reject reports than the other. (If so, who and why?)

12. Factfinding aids in settlement. (Explain)

13. Factrinding detracts from settlement. (Explain)

14. What are the problems with Oregon's factfinding process and how could the process be Improved?

15. Factfinding should be abolished. (If so, should anything take its place?)

16. Other comnents: 
The purpose of this research is to study the factfinding process. The intent of Oregon's impasse procedure is to act as a filtering process where each step reduces the number of impasses and brings the parties closer to resolution, thus encouraging good faith bargaining and reducing, possible strikes.

Please resnond to the following questions. If you have any additional comments or explanations you may wish to make, they would be appreciated; you may use the back of this sheet for that purpose.

Name

1. How many years have you been serving as a factfinder in Oregon?

2. What has been the average number of issues per case?

3. What is the most number of issues in one case?

4. What is the least number of issues in one case?

5. What are the four most important issues that cause factfinding?

1.

3,

2.

$4 \cdot$

6. Rank the five most important reasons that parties go to factfinding. 1. 2 . 5.

3.

4.

5.

Rate the following, statements according to the scale at the right. Mark your responses in the space provided.

\begin{tabular}{c|c|c|c|c|c|c|}
$\substack{n / a \\
\text { no } \\
\text { oplnion }}$ & $\begin{array}{c}-3 \\
\text { strongly } \\
\text { disagree }\end{array}$ & $\begin{array}{c}-2 \\
\text { disagree }\end{array}$ & $\begin{array}{c}-1 \\
\text { somewhat } \\
\text { disagree }\end{array}$ & $\begin{array}{c}+1 \\
\text { somewhat } \\
\text { agree }\end{array}$ & $\begin{array}{c}+2 \\
\text { agree }\end{array}$ & $\begin{array}{c}+3 \\
\text { strungly } \\
\text { agree }\end{array}$
\end{tabular}

7. Factfinding, is an effective step in the impasse resolution process in Oregon.

8. The parties generally bargain in good faith prior to factfinding. 
9. The parties discuss all issues before factfinding.

10. Parties use factfinding to court favorable public opinion.

11. Publication of the factfinding report encourages resolution.

12. The factfinding process reduces the effectiveness of mediation.

13. The cost of factfinding serves as a deterrent to its use.

14. Factfinders should not engage in mediation.

15. The factfinder should 'call them as he sees them', and not 'split the issues'.

16. Generally parties make the factfinder aware of their positions in mediation.

17. Positions taken in mediation (if known) influence the factfinder's position.

18. What are the problems with Oregon's factfinding process and how could the process be improved?

19. Factfinding should be abolished. (If so, should anything take its place?)

20. Other comments: 


\section{QUESTIONNAIRE FOR PARTIES}

The purpose of this research is to study the factfinding process. The intent of Oregon's impasse procedure is to act as a filtering process where each step reduces the number of impasses and brings the parties closer to resolution, thus encouraging good faith bargaining and reducing possible strikes.

Please respond to the following questions. If you have any additional comments or explanations you may wish to make, they would be appreciated; you may use the back of this sheet for that purpose.

1. Rank the five most important reasons that cause factfinding.

1 .

4.

2 .

5.

Rate the following statements according to the scale at the right. Mark your responses in the space provided.

\begin{tabular}{|c|c|c|c|c|c|c|}
\hline $\begin{array}{c}n / a \\
\text { no } \\
\text { opinion }\end{array}$ & $\begin{array}{l}{ }^{-3} \\
\text { strongly } \\
\text { disagree }\end{array}$ & $\mathrm{disagree}^{-2}$ & $\begin{array}{c}-1 \\
\text { somewhat } \\
\text { disagree }\end{array}$ & $\begin{array}{l}+1 \\
\text { somewhat } \\
\text { agree }\end{array}$ & $\begin{array}{c}+2 \\
\text { agree }\end{array}$ & $\begin{array}{l}+3 \\
\text { strungly } \\
\text { agree }\end{array}$ \\
\hline
\end{tabular}

2. Factfinding is useful in impasse resolution. Why or why not?

3. Generally we have confidence in factfinders.

4. Factfinders are a positive factor in impasse resolution.

5. The cost of factfinding serves as a deterrent to its use.

6. Factfinders engage in mediation (if so, at whose request?) 
7. Factfinders' recommendations are neutral (given the facts).

8. The other party generally bargains in good faith prior to factfinding.

9. Factfinding causes parties to hold back offers in mediation.

10. All issues are discussed before factfinding.

11. Factfinding reopens some issues.

12. The publication of a factfinder's report encourages impasse resolution.

13. What are the problems with Oregron's factfinding process and how could the process be improved?

14. Factifinding should be abolished. (If so, should anything take its place?)

15. Other comments: 
NEUTRALS' RANKING OF REASONS THAT CAUSE FACT-FINDING

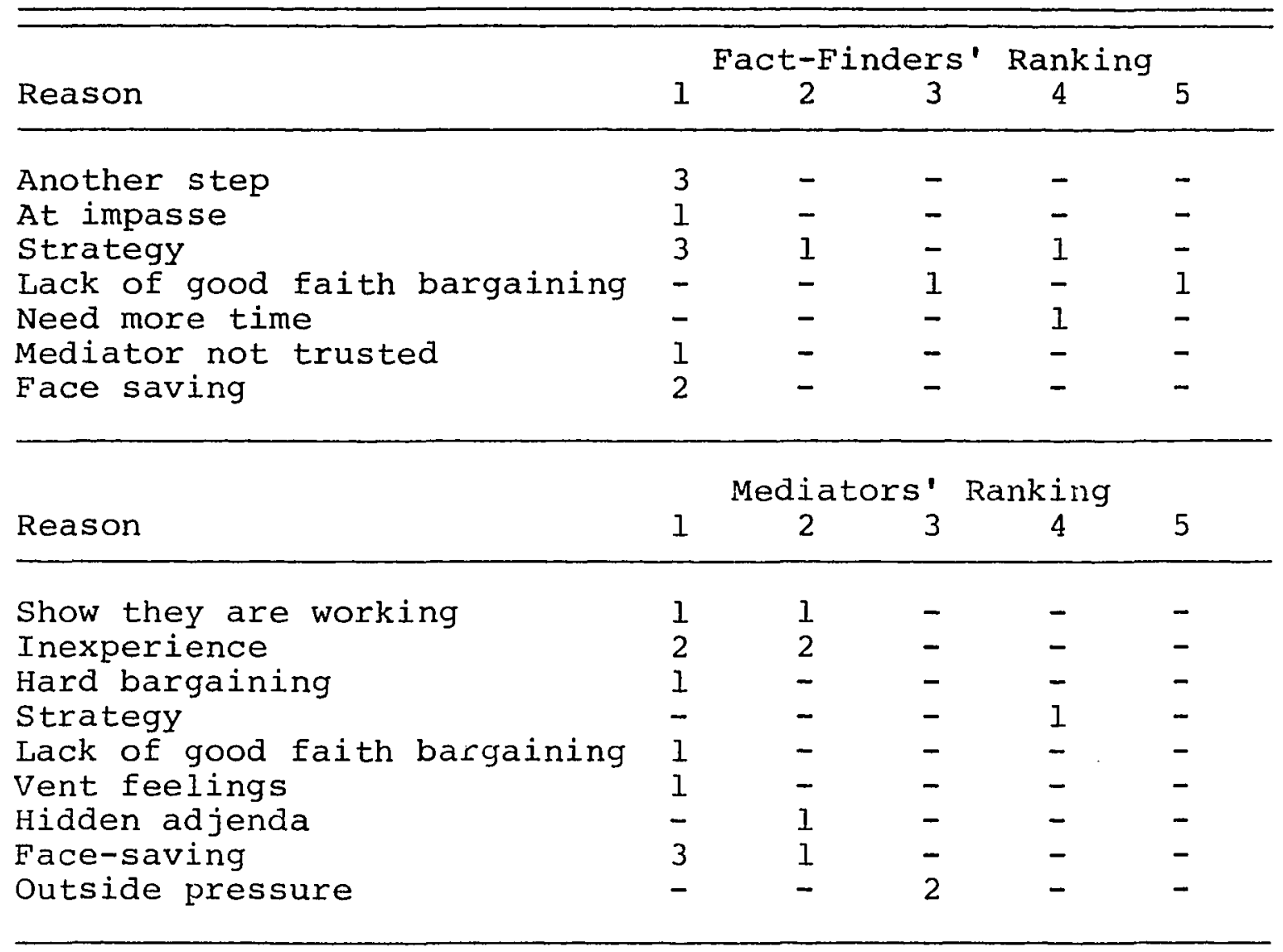


PARTIES' RANKING OF REASONS THAT CAUSE FACT-FINDING

\begin{tabular}{|c|c|c|c|c|c|}
\hline \multirow[b]{2}{*}{ Reason } & \multicolumn{5}{|c|}{ Unions' Ranking } \\
\hline & $\vdots$ & 2 & 3 & 4 & 5 \\
\hline Attitudes of parties & 1 & - & - & - & - \\
\hline Unreasonable board & 1 & 2 & - & - & - \\
\hline lack of experience & 2 & 1 & 3 & - & - \\
\hline Face-saving & - & 1 & - & - & - \\
\hline Parties at impasse & 1 & - & - & - & 1 \\
\hline Stal1 tactics & 1 & - & 1 & - & - \\
\hline Don't bargain & 1 & 2 & - & - & - \\
\hline Complex issues & 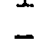 & - & 2 & - & - \\
\hline \multirow[t]{2}{*}{ ERB } & 1 & - & - & - & - \\
\hline & \multicolumn{5}{|c|}{ Management's Ranking } \\
\hline Reason & 1 & 2 & 3 & 4 & 5 \\
\hline Attitudes of parties & - & 2 & - & - & - \\
\hline Unreasonable union & 1 & - & 1 & - & - \\
\hline Lack of experience & I & - & - & 4 & - \\
\hline Face-saving & 1 & 2 & - & $\ldots$ & - \\
\hline At impasse & 1 & - & 2 & - & 1 \\
\hline Stall tactics & 2 & - & - & - & - \\
\hline Don't bargain & - & - & - & - & - \\
\hline Complex issues & - & - & - & - & - \\
\hline ERB & 2 & - & - & - & - \\
\hline Have to & 1 & - & - & - & - \\
\hline High expectations & 1 & 1 & - & - & - \\
\hline
\end{tabular}




\section{APPENDIX C}

\section{SUPPORT DATA ON FACT-FINDING REPORTS}

The following may be found in this appendix:

Title

$\underline{\text { Page }}$

List of Fact-Finding Reports Analyzed

Teaching Cases........... . 307

Non-Teaching Cases . . . . . . . 309

Number of Issues Submitted to Fact-Finding, 1974-1977 . . . . . . . . 310

Types of Issues Submitted to Fact-Finding $1974-1977$

Teaching Cases........... . 311

Non-Teaching Cases......... . 313 


\section{LIST OF FACT-FINDING REPORTS ANALYZED, TEACHING CASES, 1974-1977}

\begin{tabular}{|c|c|c|c|}
\hline \multicolumn{2}{|c|}{ Union } & \multirow{2}{*}{$\frac{\text { School District }}{\text { Oregon City }}$} & \multirow{2}{*}{$\frac{\text { Year }}{174}$} \\
\hline 1. & OEA & & \\
\hline 2. & OEA & Beaverton & 174 \\
\hline 3. & OEA & North Clackamas & 174 \\
\hline 4. & OEA & West Linn & 174 \\
\hline 5. & OEA & Lake Oswego & 174 \\
\hline 6. & OEA & Central Point & 174 \\
\hline 7. & $O E A$ & Gervais & 174 \\
\hline 8. & $O E A$ & Salem & 174 \\
\hline 9 . & OEA & Clackamas Community college & 174 \\
\hline 10. & $O E A$ & Ontario & 174 \\
\hline 11. & $O E A$ & Scappoose & 174 \\
\hline 12 . & OEA & Adrian & 174 \\
\hline \multirow[t]{2}{*}{13.} & Greater Albany & & \\
\hline & Educators & Albany & 174 \\
\hline 14. & OEA & Corbett & 174 \\
\hline 15 . & OEA & Springfield & 174 \\
\hline 16. & $\mathrm{AFT}$ & Southwestern Community college & 174 \\
\hline \multirow{2}{*}{17.} & Association of & & \\
\hline & Professors & Southern Oregon College & 174 \\
\hline 18. & OEA & Eagle Point & 174 \\
\hline 19. & $O E A$ & Coguille & 175 \\
\hline 20 . & OEA & Molalla & 175 \\
\hline 21. & OEA & McMinnville & 175 \\
\hline 22 . & OEA & Eugene & 175 \\
\hline 23. & $\mathrm{OEA}$ & Lake Oswego & 75 \\
\hline 24. & OEA & Umpqua & 175 \\
\hline 25. & $O E A$ & Jackson County & 175 \\
\hline 26. & OEA & South Lane & $\cdot 75$ \\
\hline 27. & OEA & Clatsop Community CoIlege & 175 \\
\hline 28. & OEA & Springfield & 175 \\
\hline 29 . & $O E A$ & Pleasant Valley & 175 \\
\hline 30 . & OEA & Chemeketa Community college & 175 \\
\hline 31. & OEA & Coos Bay & 175 \\
\hline 32. & OEA & Willamina & 175 \\
\hline 33. & OEA & Central Point & 175 \\
\hline 34. & OEA & Klamath County & 175 \\
\hline 35 . & OEA & Roseburg & .75 \\
\hline 36 . & OEA & Pine Eagle & 176 \\
\hline
\end{tabular}




\begin{tabular}{|c|c|c|c|}
\hline \multicolumn{2}{|c|}{ Union } & School District & \multirow{2}{*}{$\frac{\text { Year }}{17}$} \\
\hline 37. & $O E A$ & Jefferson County & \\
\hline 38. & OEA & Crook County & 176 \\
\hline 39. & OEA & Oregon City & 176 \\
\hline 40 & OEA & Jefferson & 176 \\
\hline 41 & OEA & Corvallis & 176 \\
\hline 42 & OEA & Eugene & 176 \\
\hline 43. & OEA & Albany & 176 \\
\hline 44. & OEA & Salem & 176 \\
\hline 45. & OEA & Stayton & 176 \\
\hline 46. & OEA & Woodburn & 176 \\
\hline 47. & OEA & Clackamas Community College & 176 \\
\hline 48. & OEA & Albany & $\cdot 76$ \\
\hline 49. & OEA & Coos Bay & 176 \\
\hline 50 . & OEA & Gervais & 176 \\
\hline 5.1 . & - & - & 176 \\
\hline 52. & OEA & Astoria & 176 \\
\hline 53. & OEA & Carlton & 176 \\
\hline 54. & OEA & Warrenton & 176 \\
\hline 55. & OEA & West Linn & 176 \\
\hline 56. & OEA & Scappoose & 177 \\
\hline 57. & OEA & Roseburg & 177 \\
\hline 58. & OEA & Baker & 177 \\
\hline 59. & OEA & Tigard & 177 \\
\hline 60. & OEA & Bandon & 177 \\
\hline 61. & OEA & Klamath County & 177 \\
\hline 62. & OEA & South Umpqua & 177 \\
\hline 63. & OEA & Reynolds & 177 \\
\hline 64. & OEA & Reedsport & 77 \\
\hline 65. & OEA & Dallas & 77 \\
\hline 66. & OEA & Bethel & 77 \\
\hline 67. & OEA & Redmond & 177 \\
\hline 68 & OEA & Estacada & 177 \\
\hline 69 & OEA & Riddle & $\cdot 77$ \\
\hline 70 & OEA & Salem & 77 \\
\hline 71 & OEA & Powers & 177 \\
\hline 72 & OEA & Pleasant $\mathrm{Hill}$ & 177 \\
\hline 73 & OEA & Clackamas Community college & 77 \\
\hline 74 & OEA & Ashland & 77 \\
\hline 75 & OEA & Wcicdburn & 177 \\
\hline 76 & OEA & Cascade & 177 \\
\hline 77 & OEA & Corbett & 177 \\
\hline 78 & AFT & Lane Community college & 177 \\
\hline 79 & - & - & 177 \\
\hline 80 & - & - & 177 \\
\hline 81 & OEA & West Linn & 177 \\
\hline & cates & parties are unknown & \\
\hline
\end{tabular}



LIST OF FACT-FINDING REPORTS ANALYZED,
NON-TEACHING CASES, 1974-1977

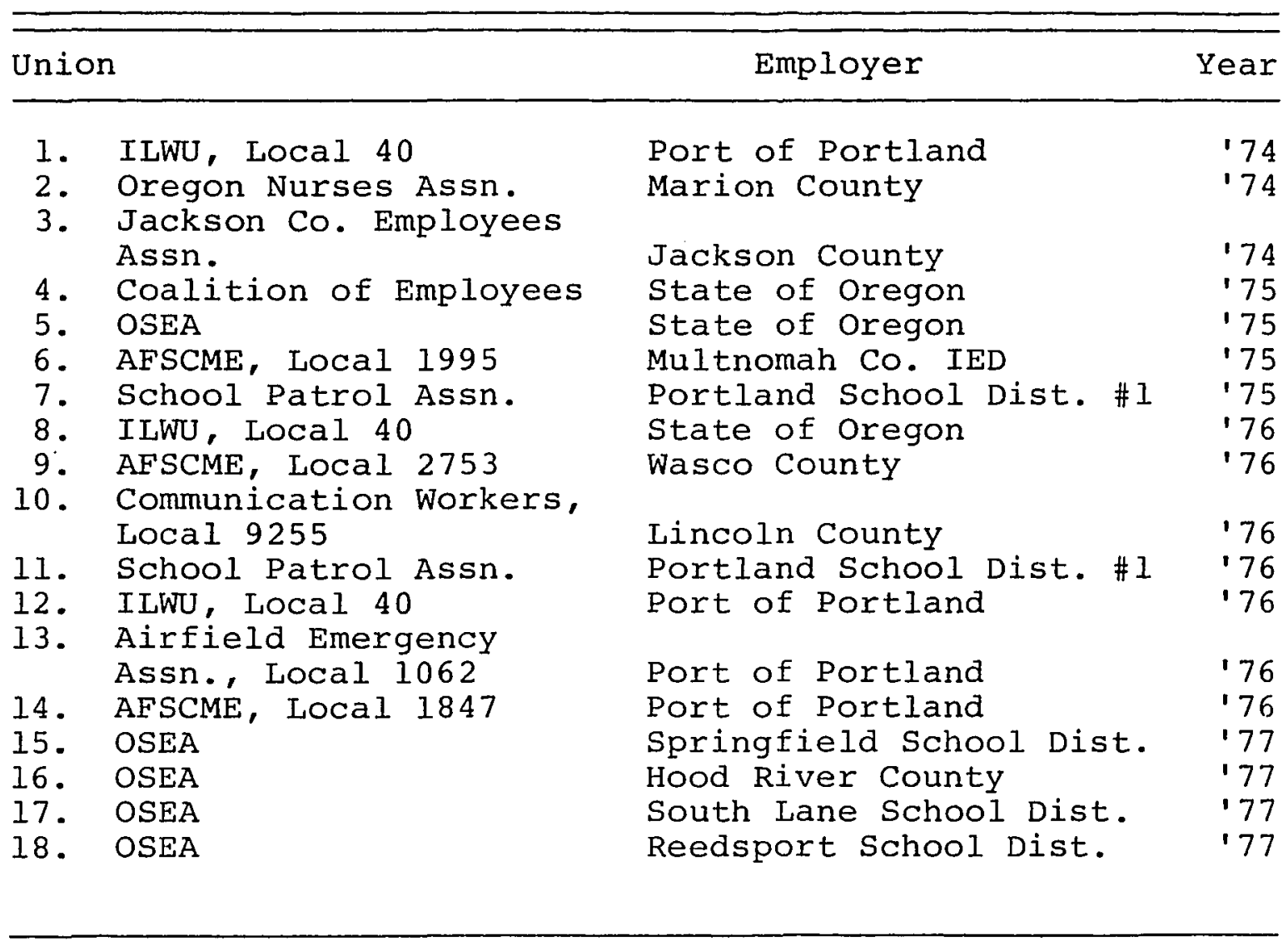


NUMBER OF ISSUES SUBMITTED TO FACT-FINDING, 1974-1977

\begin{tabular}{|c|c|c|c|c|c|c|c|}
\hline \multicolumn{4}{|c|}{ Frequency } & \multicolumn{4}{|c|}{ Frequency } \\
\hline $\begin{array}{l}\text { No. of } \\
\text { Issues }\end{array}$ & Teach. & $\begin{array}{c}\text { Non } \\
\text { Teach. }\end{array}$ & Total & $\begin{array}{l}\text { No. of } \\
\text { Issues }\end{array}$ & & $\begin{array}{c}\text { Non } \\
\text { Teach. }\end{array}$ & Total \\
\hline 1. & 2 & - & 2 & 32. & 1 & - & 1 \\
\hline 2 . & $1 \overline{3}$ & 2 & $1 \overline{5}$ & 33. & - & - & - \\
\hline 3. & 5 & 4 & 9 & 34. & 1 & - & 1 \\
\hline 4. & 4 & 4 & 8 & 35. & 1 & - & 1 \\
\hline 5 . & 5 & - & 5 & 36. & 1 & - & 1 \\
\hline 6 . & 3 & 2 & 5 & 37. & 1 & - & 1 \\
\hline 7. & - & - & - & 38 . & - & - & - \\
\hline 8. & 4 & 1 & 5 & 39. & - & - & - \\
\hline 9. & 1 & - & 1 & 40. & 1 & - & 1 \\
\hline 10 . & 3 & - & 3 & 43. & 1 & - & 1 \\
\hline 11. & 2 & - & 2 & 57. & 2 & - & 2 \\
\hline 12 . & 3 & - & 3 & 90. & 2 & - & 2 \\
\hline 13. & - & 1 & 1 & & & & \\
\hline 14. & 3 & $I$ & 4 & & $\ldots$ & $\ldots$ & $\longrightarrow$ \\
\hline 15. & 2 & 1 & 3 & Total & 81 & 18 & 99 \\
\hline 16. & 3 & - & 3 & & & & \\
\hline 17. & 2 & 1 & 3 & & & & \\
\hline 18. & 1 & 1 & 1 & & & & \\
\hline 19. & 1 & - & 1 & & & & \\
\hline 20 . & 4 & - & 4 & & & & \\
\hline 21 . & 2 & - & 2 & & & & \\
\hline 22 . & 2 & - & 2 & & & & \\
\hline 23. & 1 & - & 1 & & & & \\
\hline 24 . & - & - & - & & & & \\
\hline 25 . & - & - & - & & & & \\
\hline 26. & 1 & - & 1 & & & & \\
\hline 27. & 2 & - & 2 & & & & \\
\hline 28 . & - & - & - & & & & \\
\hline 29 . & - & - & - & & & & \\
\hline 30 . & - & - & - & & & & \\
\hline 31. & 2 & - & 2 & & & & \\
\hline
\end{tabular}

- Denotes zero 
TYPES OF ISSUES SUBMITTED TO FACT-FINDING, TEACHING CASES, 1974-1977*

\begin{tabular}{|c|c|c|c|c|c|}
\hline \multicolumn{2}{|c|}{ Issue } & $\begin{array}{l}\text { Fre- } \\
\text { quency }\end{array}$ & \multicolumn{2}{|c|}{ Issue } & $\begin{array}{c}\text { Fre- } \\
\text { quency }\end{array}$ \\
\hline 1. & Saló & 79 & 38 . & Extended contract & 10 \\
\hline 2 & Insurance & 71 & & Student fund & 1 \\
\hline 3 . & Grievance procedure & 34 & 40 . & Pay schedule - & \\
\hline 4. & Duration of agreement & 29 & & level to level & 13 \\
\hline 5 . & Fair share & 26 & 41. & Teacher-adm. Iiaison & 4 \\
\hline 6 . & Prep. period & 15 & 42 . & Personal/academic & \\
\hline 7 . & $\mathrm{x}$-duty pay & 28 & & freedom & 26 \\
\hline 8. & x-duty schedule & 25 & 43. & Evaluation of & \\
\hline 9 . & Lockout/strike clause & 25 & & Administration & 6 \\
\hline 10. & Management rights & 20 & 44. & cation & \\
\hline 11 . & Funding & 15 & & ent & 9 \\
\hline 12 . & Just cause & 23 & 45 . & I agreement & 6 \\
\hline 3 . & Teaching day & 21 & 46. & Affirmative Action & 4 \\
\hline 4. & Teaching load & 21 & 47. & Tuition reimburse- & \\
\hline 15. & Teaching calendar & 28 & & & 19 \\
\hline 6. & Class size & 11 & 48 . & Classroom disci- & \\
\hline 7. & Contract services & 6 & & pline & 23 \\
\hline 18. & Specialists & 6 & 49 . & Reduction in staff & 23 \\
\hline 19. & Aides & 9 & 50 . & Dues/payroll deduc- & \\
\hline 20 . & Vacancy \& transfer & 20 & & & 16 \\
\hline 21 . & Teacher evaluation & 27 & & Separability clause & 7 \\
\hline 22 . & Teacher files & 8 & & School closure & 3 \\
\hline 23. & Complaint procedure & 73 & & Contract language & 2 \\
\hline 24. & Leave, sick & 24 & & Disciplinary action & \\
\hline 25 . & Leave, maternity & 10 & & cedure & 3 \\
\hline 26 . & Leave, parental & 5 & 55 & Special children & 2 \\
\hline 27 . & Leave, emergency & 5 & 56 . & Adequate facilities & 8 \\
\hline 28 . & Leave, personal & 19 & 57. & Staffing & 3 \\
\hline 29. & Leave, professional & 22 & 58. & Personnel policies & 2 \\
\hline 30. & Leave, bereavement & 7 & 5 & Textbooks & 7 \\
\hline 31 . & Leave, unpaid absence & 11 & 60 . & Meal allowance & 1 \\
\hline 32 . & Leave, association & 12 & 61. & Maintenance of & \\
\hline 33. & Retirement pay & 4 & & standards & 19 \\
\hline 34. & Auto allowance & 5 & 62. & Instructional & \\
\hline & Summer pay & 4 & & program & 9 \\
\hline 36 & Union rights & 20 & & Required meetings & \\
\hline & Substitutes & 15 & & Contract compliance & 1 \\
\hline
\end{tabular}




\begin{tabular}{|c|c|c|c|c|c|}
\hline \multicolumn{2}{|c|}{ Issue } & \multirow{4}{*}{$\begin{array}{r}\begin{array}{r}\text { Fre- } \\
\text { quency }\end{array} \\
1 \\
6 \\
1\end{array}$} & \multicolumn{2}{|c|}{ Issue } & $\begin{array}{l}\text { Fre- } \\
\text { quency }\end{array}$ \\
\hline 65 . & Job description & & 76 . & Unit determination & 2 \\
\hline 66 . & Curriculum development & & 77. & Compliance $\mathrm{w} /$ master & \\
\hline 67. & Prior practice clause & & & contract & 7 \\
\hline 68. & Use of equipment & 2 & 78. & Severance pay & 3 \\
\hline 69. & Tenure & 3 & 79 . & Assault \& battery & 1 \\
\hline 70 & College governance & 2 & 80 . & Grading & 1 \\
\hline 71 & Teaching assignments & 9 & 81 . & Tuition waiver & 3 \\
\hline 72 . & Division organization & 1 & 82 . & Teaching apparel & 1 \\
\hline 73. & Secretarial assistance & 1 & 83. & Telephone calls & 1 \\
\hline 74 . & Professional growth & 7 & 84 . & Recognition & 2 \\
\hline 75 . & Emergency clause & 1 & 85 . & Teaching conditions & 6 \\
\hline
\end{tabular}

* Based upon a sample of 81 of 93 reports issued; because some issues were consolidated only 86 issues appear on this list 
TYPES OF ISSUES SUBMITTED TO FACT-FINDING
NON-TEACHING CASES, 1974-1977*

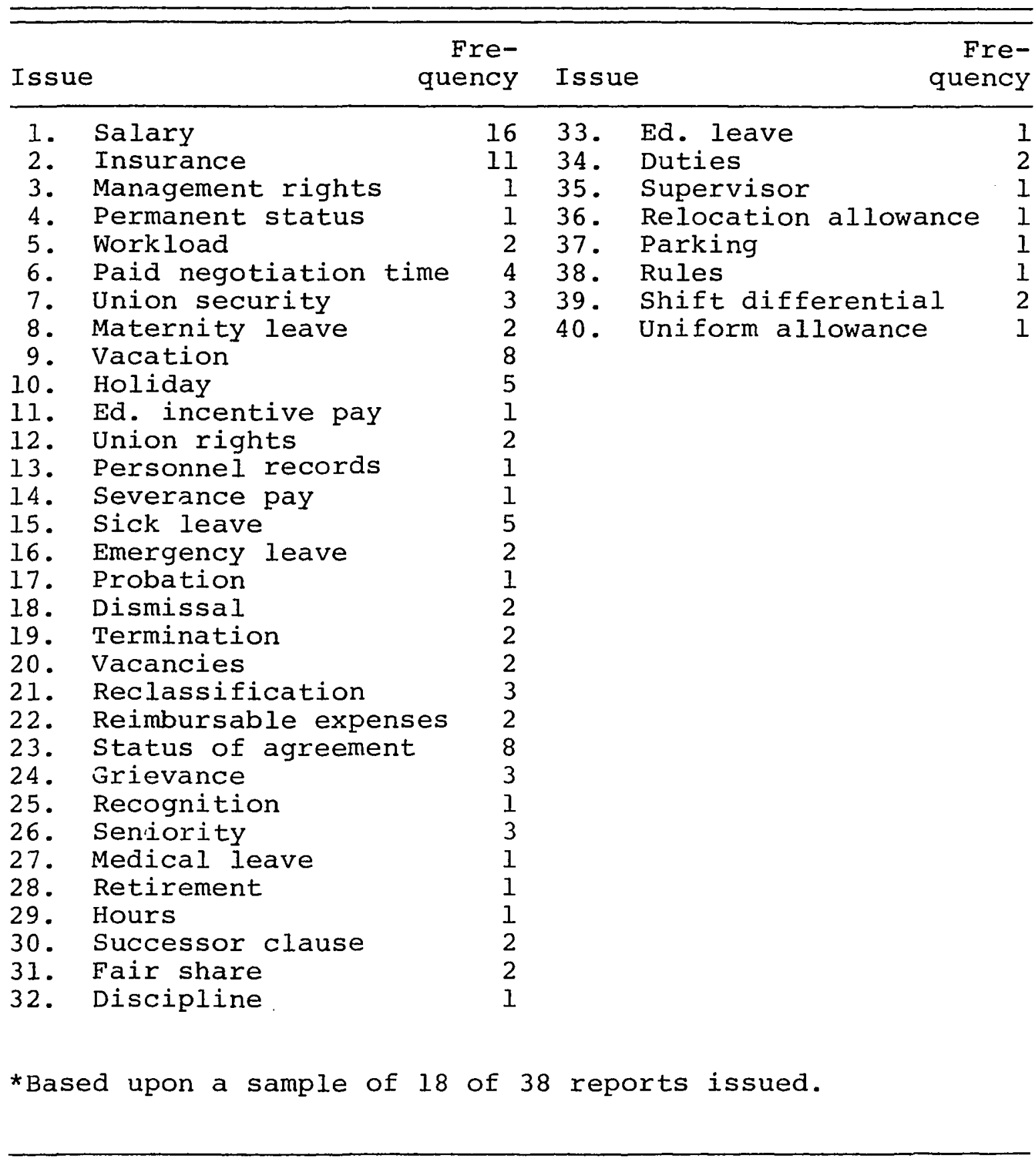




\section{APPENDIX D \\ STATUTES AND RELATED INFORMATION}

The following may be found in this appendix:

Title

$\underline{\text { Page }}$

State Statutes: Negotiation Impasse

Procedures in 1972 . . . . . . . . . . . . . . 315

State Conciliation Service Fact-

Finding Riles . . . . . . . . . . . . . . 316

Sample Letter of Understanding

Regarding Mediation . . . . . . . . . 320 
STATE STATUTES: NEGOTIATION IMPASSE PROCEDURES IN 1972

\begin{tabular}{|c|c|c|c|c|c|c|c|c|}
\hline \multirow[b]{2}{*}{ State } & \multirow[b]{2}{*}{ Coverage } & \multirow{2}{*}{$\begin{array}{l}\text { Medi- } \\
\text { ation }\end{array}$} & \multirow{2}{*}{$\begin{array}{l}\text { Fact- } \\
\text { finding }\end{array}$} & \multirow{2}{*}{$\begin{array}{l}\text { Up to } \\
\text { the } \\
\text { partics }\end{array}$} & \multicolumn{4}{|c|}{ Arbitrat } \\
\hline & & & & & $\begin{array}{l}\text { ndvisory } \\
\text { natur }\end{array}$ & $\begin{array}{l}\text { tary } \\
\text { Binding }\end{array}$ & $\begin{array}{l}\text { Conipul } \\
\text { Advisory }\end{array}$ & $\begin{array}{l}\text { Scry } \\
\text { Binding }\end{array}$ \\
\hline $\begin{array}{l}\text { Alaska } \\
\text { californta }\end{array}$ & $\begin{array}{l}\text { Teachors } \\
\text { Municipal }\end{array}$ & $\begin{array}{l}x \\
x\end{array}$ & & & & & & \\
\hline connectucut & $\begin{array}{l}\text { Municipal } \\
\text { Municipal }\end{array}$ & $\hat{x}$ & $\mathbf{x}$ & $\boldsymbol{x}$ & & & & \\
\hline Delaware & $\begin{array}{l}\text { Teachors } \\
\text { State \& Municipol }\end{array}$ & $\begin{array}{l}x \\
x\end{array}$ & & $x$ & $\mathbf{x}$ & & & \\
\hline & Teachers & $\hat{x}$ & $\mathbf{x}$ & $x$ & & & & \\
\hline Flozida & $\begin{array}{l}\text { Public Transit } \\
\text { Teachers }\end{array}$ & & & $\mathbf{x}$ & & & $x$ & \\
\hline Gcorgla & Firefighters & & & & & & $\ddot{x}$ & \\
\hline $\begin{array}{l}\text { Hawali } \\
\text { Idaho }\end{array}$ & $\begin{array}{l}\text { Fircfichliters } \\
\text { Public Employees } \\
\text { Teachers }\end{array}$ & $\begin{array}{l}x \\
x\end{array}$ & $\begin{array}{l}x \\
x \\
x\end{array}$ & & & $\mathbf{x}$ & & \\
\hline Illinois & Firofighters & & $\bar{x}$ & & & & & \\
\hline Aldinots & $\begin{array}{l}\text { Fircfighters } \\
\text { Public Transit }\end{array}$ & & & $\mathbf{x}$ & & & $\mathbf{x}$ & \\
\hline $\begin{array}{l}\text { Iowa } \\
\text { Kansas }\end{array}$ & $\begin{array}{l}\text { Fircfighters } \\
\text { Public Emioloyees }\end{array}$ & $\mathrm{x}$ & $x$ & & $\mathbf{x}$ & & & \\
\hline $\begin{array}{l}\text { Louisiana } \\
\text { Maine }\end{array}$ & $\begin{array}{l}\text { Public Transit } \\
\text { Municipal }\end{array}$ & $x$ & $\mathrm{x}$ & & & $\mathbf{x}$ & $\mathbf{x}$ & $\begin{array}{l}x \\
x\end{array}$ \\
\hline $\begin{array}{l}\text { Maryland } \\
\text { Massachusetts }\end{array}$ & Teachors & $\mathrm{x}$ & & & & & & \\
\hline Massachusetts & $\begin{array}{l}\text { Statc } \\
\text { Municipal }\end{array}$ & $\begin{array}{l}x \\
x\end{array}$ & $\begin{array}{l}x \\
x\end{array}$ & & & & & \\
\hline & & $\mathrm{x}$ & $\bar{x}$ & & & $\mathbf{x}$ & & \\
\hline Michigan & Police \& Firefighters & $=x$ & $\begin{array}{l}x \\
x\end{array}$ & & & & & $x$ \\
\hline Minnesota & & $x$ & $\hat{x}$ & & & & & \\
\hline & $\begin{array}{l}\text { Teachers } \\
\text { Nonprof it llospitals }\end{array}$ & $\stackrel{x}{x}$ & $\mathrm{x}$ & & $\%$ & $\mathbf{x}$ & & \\
\hline $\begin{array}{l}\text { Missour } 1 \\
\text { Montana }\end{array}$ & $\begin{array}{l}\text { Firefighters } \\
\text { Teachers }\end{array}$ & & $\mathrm{x}$ & & $\mathbf{x}$ & & & \\
\hline Nehraska & $\begin{array}{l}\text { Public Employees } \\
\text { Teachers }\end{array}$ & $\mathbf{x}$ & $\begin{array}{l}\ddot{x} \\
x\end{array}$ & & & & & $\begin{array}{l}x \\
x\end{array}$ \\
\hline $\begin{array}{l}\text { Nevada } \\
\text { New llampshire }\end{array}$ & $\begin{array}{l}\text { Municipal \& Nurses } \\
\text { Statel }\end{array}$ & $\begin{array}{l}x \\
x\end{array}$ & $\begin{array}{l}x \\
x\end{array}$ & & & $\mathbf{x}$ & & \\
\hline New Jersey & Public Fimployees & $\hat{\mathrm{x}}$ & $\hat{x}$ & $\mathbf{x}$ & & & & \\
\hline $\begin{array}{l}\text { New York } \\
\text { North Dakota }\end{array}$ & $\begin{array}{l}\text { Public Employees } \\
\text { Public Employees }\end{array}$ & $\begin{array}{l}x \\
x\end{array}$ & $\mathrm{x}$ & $\mathbf{x}$ & & & & \\
\hline Oxlahoma & Teachers & $\mathrm{x}$ & $x$ & & $r^{2}$ & & & \\
\hline $\begin{array}{l}\text { Oklahoma } \\
\text { Oreqon } \\
\text { Pennsylvania }\end{array}$ & $\begin{array}{l}\text { Police Firefighters } \\
\text { State \& Municipal }\end{array}$ & $\mathrm{x}$ & $\boldsymbol{x}$ & $\mathbf{x}$ & & & & \\
\hline Pennsylvania & $\begin{array}{l}\text { Police \& Firefighters } \\
\text { Public Employees }\end{array}$ & $\mathrm{s}$ & $-x$ & & $\mathbf{x}$ & $\mathbf{x}$ & & $\begin{array}{l}x \\
x\end{array}$ \\
\hline Rhode Island & $\begin{array}{l}\text { Public Transit } \\
\text { State Ejnployees }\end{array}$ & & & & & $\ddot{x}$ & & \\
\hline & $\begin{array}{l}\text { Municipal Fmployees } \\
\text { Teachers }\end{array}$ & $\begin{array}{l}x \\
x\end{array}$ & & & $\mathbf{x}$ & $\mathbf{x}$ & $\mathbf{x}$ & $x$ \\
\hline South Dakota & $\begin{array}{l}\text { Pollice } \\
\text { Firefighters }\end{array}$ & $x$ & $x$ & & & & & $\begin{array}{l}x \\
x\end{array}$ \\
\hline & $\begin{array}{l}\text { Puhlic Employees } \\
\text { Police \& Firefighters }\end{array}$ & $s^{n}$ & & & & & & $\mathbf{x}$ \\
\hline Vermont & $\begin{array}{l}\text { State limployces } \\
\text { Municipal Enployees }\end{array}$ & $\begin{array}{l}x \\
x\end{array}$ & $\begin{array}{l}x \\
x\end{array}$ & & & $\mathbf{x}$ & & $x^{4}$ \\
\hline Washington & $\begin{array}{l}\text { Teachers } \\
\text { Community College } \\
\text { Acadenic Imployees } \\
\text { Municipal Employees } \\
\text { Teachers } \\
\text { Public Utility } \\
\text { Districts }\end{array}$ & $x$ & $\begin{array}{l}x \\
x \\
x\end{array}$ & & & & $"$ & \\
\hline Wisconsin & $\begin{array}{l}\text { State rimployces } \\
\text { Municipal Fimployces }\end{array}$ & $\begin{array}{l}x \\
x\end{array}$ & $\begin{array}{l}\mathbf{x} \\
\mathbf{x}\end{array}$ & & & & & \\
\hline Wyoming & Firefighters & & & & & & & $\mathbf{x}$ \\
\hline
\end{tabular}

Source: Gilroy. Thomas $P$. and Sincropi. Anthony V. pispute Settlement In the Public Sector: The state of the Art, Washington, D.C.: U. S. Governient Printing office, 1972.

1 procedure may be negotiated by the parties in licu of procedures noted or including procedures noted.

${ }^{2}$ If the munleipallty accepts the advisory decioion, it ls binding on the parties.

In Rhode Island, procedures may be negotlated by the partles but law sets out no procedures that must be Included or procefures to be uged in lieu of a negotiated procedure.

Trirefighters only. 
15-015 Factfinding If the dispute has not been settled after 15 days of mediation, either party may request the board to inftlate factfinding, or the board, on its own motion, may infitate such factfinding if 1 deems it approprlate and in the public interest.

1. Selection of Factfinder(s) If the board decides to inftiate factfinding, it shall so notify the parties and they shall have five days after receipt of such notice in which to mutualiy select their own factfinder. If they fail to do so, the board will submit to them a list of five qualified factfinders. From that list each party shall alternately strike two names, with the order of striking being determined by lot. The remaining individual shall be the factfinder.

If both parties should desire a panel of three factfinders, they shall so notify the board and the $t$ sard will then submit a list of seven factfinders. From that list each party shall alternately strlke two names, with the order of striking being determined by lot. The remaining three persc:s shall be the factfinders.

The parties shall advise the board of their choice within five days after receipt of the list. If they fail to do so, the board shall appoint the factfinder(s) from the list.

If, however, one of the parties strikes the names as provided above and the other party fails to do so, the board shall appoint the factfinder only from the names remaining on the list. If the factfinder so selected is unable to accept his appointment, the parties shall so notify the board and the board shall then submit another list of names.

2. Qualifications of Factfinder No person shall serve as a factfinder in any factfinding in which he has any financial or personal interest in the result of the factfinding, unless the parties, in writing, waive such disqualification.

3. Notice of Appointinent Upon selection of the factfinder, the parties shall notify the board and the factfinder of his selection.

4. Disclosure by Factfinder of Disqualifjeation Prior to accepting his appointment, the prospective factinder shall disclose any circumstances likely to create a presumption of bias or which he belfeves might disqualify him as an impartial factfinder. Upon receipt of such information, the board shall immediately disclose it to the parties. If either party declines to waive the presumptive disqualification, the vacancy thus created shall be filled in the sane manner as that governing the making of the original appointment.

5. Vacancies If any factinder should resign, die, withdraw, refuse or be unable to or disqualified to perform the duties of his office, the board shall, upon proof satisfactory to it, declare the office vacant. Vacancjes shall be filled in the same manner as that governing the making of the original appointment, and the watter shall be reheard by the now factfinder. 
6. Time and Place of Hearing The fact finder shail fix the time and place for each hearing.

7. Representation by Counsel Any party may be represented by counsel or by other authorized representative.

8. List of Issues Each party shall submit a written list of the issues it intends to submit to factfinding to the factfinder and to the other party at least seven days before the date of the factfinding hearing.

9. Subpoenas If the parties wish subpoenas, they may request them of the Public Employe Relations Board not less than five days prior to the date set for the factfinding hearing.

10. Attendance at Hearings The factfinding hearing shall be open to the public unless otherwise mutually agreed to by the parties.

11. Adjourninents The factfinder,for good cause shown, may adjourn the hearing upon the request of a party or upon his own initiative, and shall adjourn when all parties agree thereto.

12. Oaths In the discretion of the factfinder, all witnesses who testify at the hearing may be sworn or make an affirmance.

13. Order of Procecdings The order of presentation at the hearing shall be as mutually agreed between the parties or as determined by the factfinder.

14. Exhlbits Fach exhibit introduced by a party shall be filed with the factifinder and a copy shall be provided to the other party. The exhibits filed with the factfinder shall be retained by him unless the parties otherwise agree, or unless the factfinder otherwise permits.

15. Evidence The parties may offer such evidence as they desire and shall produce such additional evidence as the factfinder may deem necessary to an understanding and determination of the dispute. The factfinder shall be the judge of the relevancy and nateriality of the evidence offered and conformity to legal rules of evidence shall not be necessary. All evidence shall be taken in the presence of all of the partics except where any of the parties is absent in default or has waived his right to be present. In making his findings of fact and recommendations, the factfinder shall consider the factors set forth in ORS 243.746(4). 
16. Factfinding in the Absence of a Party The factfinder may proceed In the absence of any party, who, after due notice, falls to be present or falls to obtain an adjournment. Findings of fact and recommendations shall not be made solely on the default of a party. The factfinder shall require the other party to submit such evidence as he may require for the making of findings of fact and recommendations.

17. Closing of Hearings The factfinder shall inquire of all parties whether they have any further proofs to offer or witnesses to be heard. Upon receiving negative replies, the factfinder shall declare the hearings closed and the time thereof shall be recorded. If briefs of other documents are to be filed, the hearings shall be declared closed as of the final date set by the factfinder for filing of the briefs.

18. Reopening of Hearings The hearings may be reopened by the factfinder on his own motion, or on the motion of either party for good cause shown, at any time before the findings of fact and recommendations are made, but if the reopening of the hearing would prevent the making of the findings of fact and recommendations within the spectfic time provided by law, the matter may not be reopened, unless both parties agree upon an extension of such time limit.

19. Waiver of Rules Any party who proceeds with the factfinding after knowledge that any provision or requirement of these rules has not been complied with and who fails to state his objection thereto in writing, shall be deemed to have waived his right to object.

20. Waiver of Oral Hearing The parties may provide, by written agreement, for the waiver of oral hearings.

21. Serving of Notices Any papers, notices or process necessary or proper for the initiation or continuation of factfinding under these rules may be served upon a party (a) by mail addressed to such party or his attorney at his last known address, or (b) by personal service.

22. Time of Findings of Fact and Recommendations Not more than 30 days from the date of conclusion of the hearings, the factfinder shall make written findings of fact and recommendations for resolution of the dispute and shall serve such findings and recommendations upon the parties and upon the board. Service nay be personal or by registered or certified mail.

23. Form of Findings of Fact and Recommendations The findings of fact and recommendations shall be in writing and shall be signed either by the factfinder or by a concurring majority, if there be more than one factinder.

24. Expenses The expenses of witnesses for either side shall be paid by the party producing such witnesses. Expenses of the factfinding, including required traveling and other expense of the factfinder and the expenses of any witnesses or the cost of any proofs produced at the direct request of the factfinder, shall be borne equally by the parties. 
25. Interpretation and Application of Rules The factfinder shall Interpret and apply these rules insofar as they relate to his powers and dutfes. When there is more than one factfinder and a difference arises among them concerning the meaning or application of any such rules, it shall be declded by majority vote.

26. Parties' Responsibility after Factfinding Not more than five working days after the findings and recomendations have been sent, the parties shall notify the board and each other whether or not they accept the recommendations of the factfinder. 
SAMPLE LETTER OF UNDERSTANDING REGARDING MEDIATION

\author{
LINCOLN COUNTY SCHOOL DISTRICT \\ and \\ LINCOLN COUNTY EDUCATION ASSOCIATION \\ , 1978
}

UNDERSTANDING REGARDING MEDIATION

The mediation process in confidential.

The agreements made during mediation are tentative.

No evidence may be introduced by either party at the fact-finding about tentative agreements made, nor even proposals advanced during mediation by either party on items which go to the factfinder for recommendation.

If final agreement of an entire contract is not reached during mediation, only the items tentatively agreed upon during negotiations and mediation that the parties, after mediation, mutually agree will not go to the factfinding for recommendation shall be left out of factfinding.

LINCOLN COUNTY SCHOOL DISTRICT

BY

IINCOLN COUNTY EDUCATION ASSOCIATION

By 